Article published in the Geological Society of America Bulletin, Geological Society of America

Alexis Licht, Guillaume Dupont-Nivet, Zaw Win, Hnin Hnin Swe, Pierrick Roperch, et al.. Paleogene evolution of the Burmese forearc basin and implications for the history of India-Asia convergence. Geological Society of America Bulletin, Geological Society of America, 2019, 131 (5-6), pp.730-748. 〈10.1130/B35002.1〉. 〈insu01901808> 


\title{
Paleogene evolution of the Burmese forearc basin and implications for the history of India-Asia convergence
}

\author{
Alexis Licht ${ }^{1, \uparrow}$, Guillaume Dupont-Nivet ${ }^{2,3,4}$, Zaw Win ${ }^{5}$, Hnin Hnin Swe ${ }^{6}$, \\ Myat Kaythi ${ }^{6}$, Pierrick Roperch ${ }^{2}$, Tamas Ugrai ${ }^{1}$, Virginia Littell ${ }^{1}$, Diana Park ${ }^{1}$, \\ Jan Westerweel ${ }^{2}$, Dominic Jones ${ }^{1}$, Fernando Poblete ${ }^{2,7}$, Day Wa Aung ${ }^{6}$, \\ Huasheng Huang ${ }^{8}$, Carina Hoorn ${ }^{8}$, and Kyaing Sein ${ }^{9}$ \\ ${ }^{1}$ Department of Earth and Space Sciences, University of Washington, Seattle, \\ Washington 98195, USA \\ ${ }^{2}$ Géosciences Rennes, UMR CNRS 6118, Université de Rennes, 35042 Rennes Cedex, \\ France
}

${ }^{3}$ Potsdam University, Institute of Earth and Environmental Science, 14476 Potsdam, Germany

${ }^{4}$ Key Laboratory of Orogenic Belts and Crustal Evolution, Ministry of Education, Beijing, China

${ }^{5}$ Geology Department, Shwe Bo University, Sagaing Region, Myanmar

${ }^{6}$ Geology Department, University of Yangon, Pyay Road, Yangon, Myanmar

${ }^{7}$ Instituto de Ciencias de la Ingeniería, Universidad de O'Higgins, Rancagua, Chile

${ }^{8}$ Institute for Biodiversity and Ecosystem Dynamics, University of Amsterdam, 1098

XH Amsterdam, The Netherlands

${ }^{9}$ Myanmar Geosciences Society, Yangon, Myanmar

\begin{abstract}
The geological history of the Burmese subduction margin, where India obliquely subducts below Indochina, remains poorly documented although it is key to deciphering geodynamic models for the evolution of the broader Tibetan-Himalayan orogen. Various scenarios for the evolution of the orogen have been proposed, including a collision of India with Myanmar in the Paleogene, a significant extrusion of Myanmar and Indochina from the India-Asia collision zone, or very little change in paleogeography and subduction regime since the India-Asia collision. This article examines the history of the Burmese forearc basin, with a particular focus on Eocene-Oligocene times to
\end{abstract}


reconstruct the evolution of the Burmese margin during the early stages of the IndiaAsia collision. We report on sedimentological, geochemical, petrographical, and geochronological data from the Chindwin Basin-the northern part of the Burmese forearc-and integrate these results with previous data from other basins in central Myanmar.

Our results show that the Burmese margin acted as a regular Andean-type subduction margin until the late middle Eocene, with a forearc basin that was open to the trench and fed by the denudation of the Andean volcanic arc to the east. We show that the modern tectonic configuration of central Myanmar formed 39-37 million years ago, when the Burmese margin shifted from an Andean-type margin to a hyper-oblique margin. The forearc basin was quickly partitioned into individual pull-apart basins, bounded to the west by a quickly emerged accretionary prism, and to the east by synchronously exhumed basement rocks, including coeval high-grade metamorphics. We interpret this shift as resulting from the onset of strike-slip deformation on the subduction margin leading to the formation of a paleo-sliver plate, with a paleo fault system in the accretionary prism, pull-apart basins in the forearc, and another paleo fault system in the backarc. This evolution implies that hyper-oblique convergence below the Burmese margin is at least twice older than previously thought. Our results reject any India-Asia convergence scenario involving an early Paleogene collision of India with Myanmar. In contrast, our results validate conservative geodynamic models arguing for a close-to-modern pre-collisional paleogeometry for the Indochina Peninsula, and indicate that any post-collisional rotation of Indochina, if it occurred at all, must have been achieved by the late middle Eocene.

\section{INTRODUCTION}

The Himalayan-Tibetan orogen, a result of the India-Asia collision, is commonly considered as the type orogen for continent-continent collisional systems and a natural laboratory to study the dynamics of continental convergence (Yin and Harrison, 2000). Our seemingly vast knowledge of the Himalayan-Tibetan system comes from decades of work along $\sim 2600 \mathrm{~km}$ of the approximately west-east-trending arcuate strike of the orogen in NW India, Nepal, Bhutan, and Tibet (e.g., Allègre et al., 1984; Chen et al., 1993; Yin et al., 1994; Searle et al., 1997; Harrison et al., 1998; DeCelles et al., 2002, 2014; Najman et al., 2010, 2017; McQuarrie et al., 2014; Ma et al., 2016). Yet, the pre-collisional 
paleogeography of the Asian active margin, the chronology of the collision, and the deformation mechanisms accommodating the post-collisional convergence remain debated (e.g., Shen et al., 2001; Royden et al., 2008; van Hinsbergen et al., 2011a; Replumaz et al., 2010, 2013). Noticeably, an enormous spatial gap is left in our understanding of the convergence. With some notable exceptions (Pivnik et al., 1998; Socquet et al., 2002; Rangin et al., 2013), 1500 km of the orogen trending north-south in Myanmar is underrepresented in our efforts to understand this complex system. The histories of the Burma Terrane, a small individual continental block located at the edge of the eastern Himalayan syntaxis, and of the active margin on the Burma Terrane, where the Indian plate subducts below the western edge of peninsular Indochina (Fig. 1A), remain virtually undocumented and are the focus of intense speculation. Reconstructing the history of the Burmese margin is, however, a prerequisite for any paleotectonic and geodynamic understanding of the broader Tibetan-Himalayan orogen. Two end-member geodynamic models are proposed to explain how Asian lithospheric deformation has accommodated the convergence of India and Asia since the collision began: (1) lateral extrusion of Asian lithospheric blocks away from the collision zone with partial underthrusting of Asian blocks along strike-slip faults (e.g., Tapponnier et al., 1982; Replumaz and Tapponnier, 2003; Royden et al., 2008; Replumaz et al., 2010, 2013; Cogné et al., 2013), and (2) homogeneous thickening and continuous deformation of weaker Asian lithosphere (e.g., England and Houseman; 1986, Molnar et al., 1993; Hallet and Molnar, 2001; Shen et al., 2001; van Hinsbergen et al., 2011a). In most plate kinematic models dominated by extrusion, India collides with the Burmese subduction margin in the early time of the collision ca. 55 Ma (Fig. 1B; Tapponnier et al., 1982; Replumaz and Tapponnier, 2003; Replumaz et al., 2010; Cogné et al., 2013; Gibbons et al., 2015). The Burma Terrane and Indochina are later extruded from the collision zone to end up in their modern position, south of the Eastern Himalayan syntaxis. In other kinematic models dominated by extrusion, India does not collide with the Burma Terrane but with the Lhasa Terrane in Tibet (Fig. 1B); the Burma Terrane is located to the southeast of the Lhasa Terrane and is dragged northward by the Indian Plate while Indochina is extruded eastward (Royden et al., 2008). By contrast, models dominated by homogeneous thickening and continuous deformation of Asian lithosphere propose a more conservative paleogeography for the Burmese margin (Fig. 1C): pre-collisional Myanmar and peninsular Indochina already form a narrow peninsula at the 
southeastward extremity of East Asia very close to their modern position (Molnar et al., 1993; Hallet and Molnar, 2001; Shen et al., 2001; van Hinsbergen et al., 2011a). Most of the continuous deformation models suggest that the Burmese subduction margin lies to the east of the collision zone and is thus not particularly impacted by post-collisional deformation (van Hinsbergen et al., 2011a, 2012; Hall, 2012), but others propose that India collided first with the Burmese margin before continuing northward to its modern position (Aitchison et al., 2007; Vérard et al., 2017).
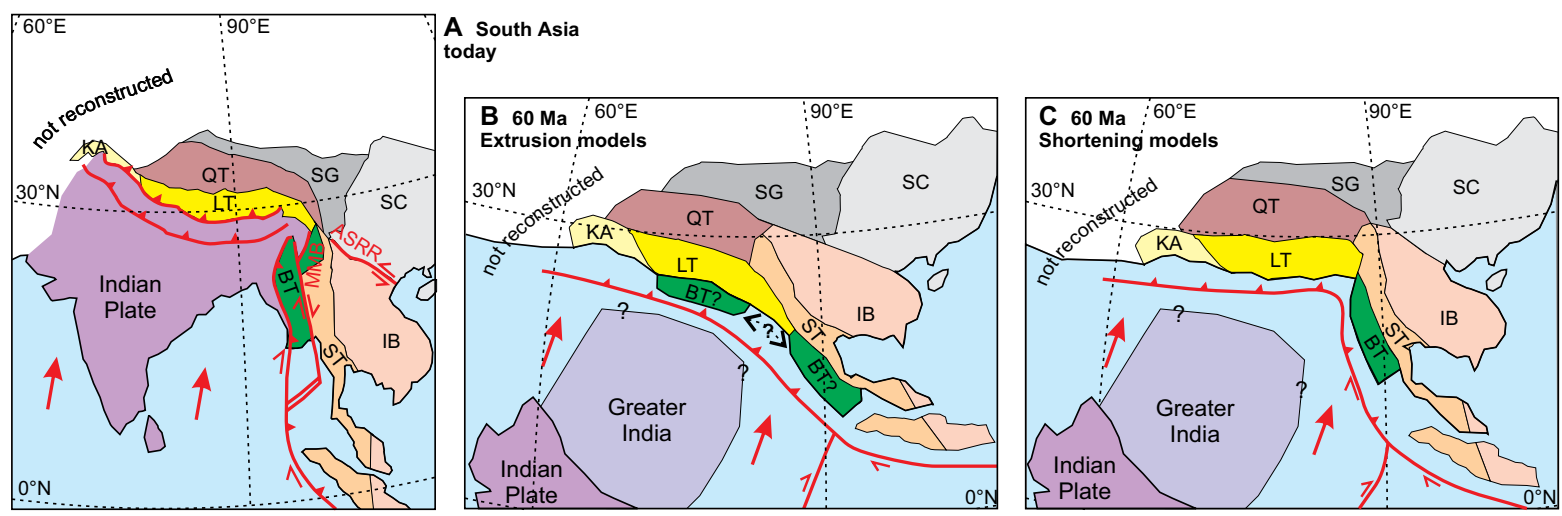

Figure 1. Structural map of South Asia today (A) and hypothetical maps 60 million years ago following deformation models dominated by extrusion (B) or shortening processes $(C)$. Modified after Replumaz and Tapponnier (2003), Pubellier (2008), van Hinsbergen et al. (2011a), Hall (2012), and Royden et al. (2008). KA-Kohistan Arc; LT-Lhasa Terrane; QT-Qiangtang Terrane; SG-Songpan Ganzi complex; SC-South China Craton; BTBurma terrane; ST-Sibumasu Terrane; IB-Indochina Terrane; MMB-Mogok Metamorphic Belt; ASRR-Ailao Shan-Red River shear zone. The red arrows indicate the direction of convergence (after Lee and Lawver, 1995; van Hinsbergen et al., 2011b). Note that before the India-Asia collision, extrusion models propose that the Burma Terrane was located either along the collision front (e.g., Replumaz and Tapponnier, 2003) or farther east, away from the collision zone (e.g., Royden et al., 2008). 


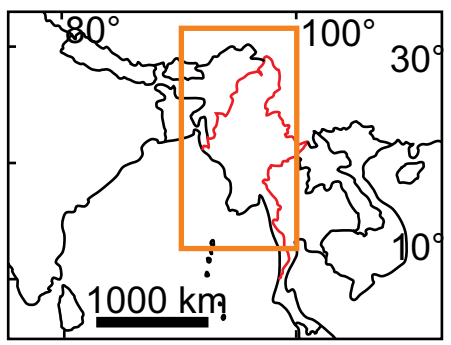

\#) Section on Fig. 3

$\therefore$ Myanmar borders

Convergence zone

N Main Fault

Area of study

Tibetan-Himalayan domain:

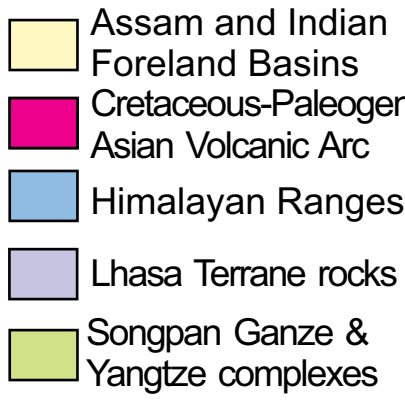

Myanmar domain:
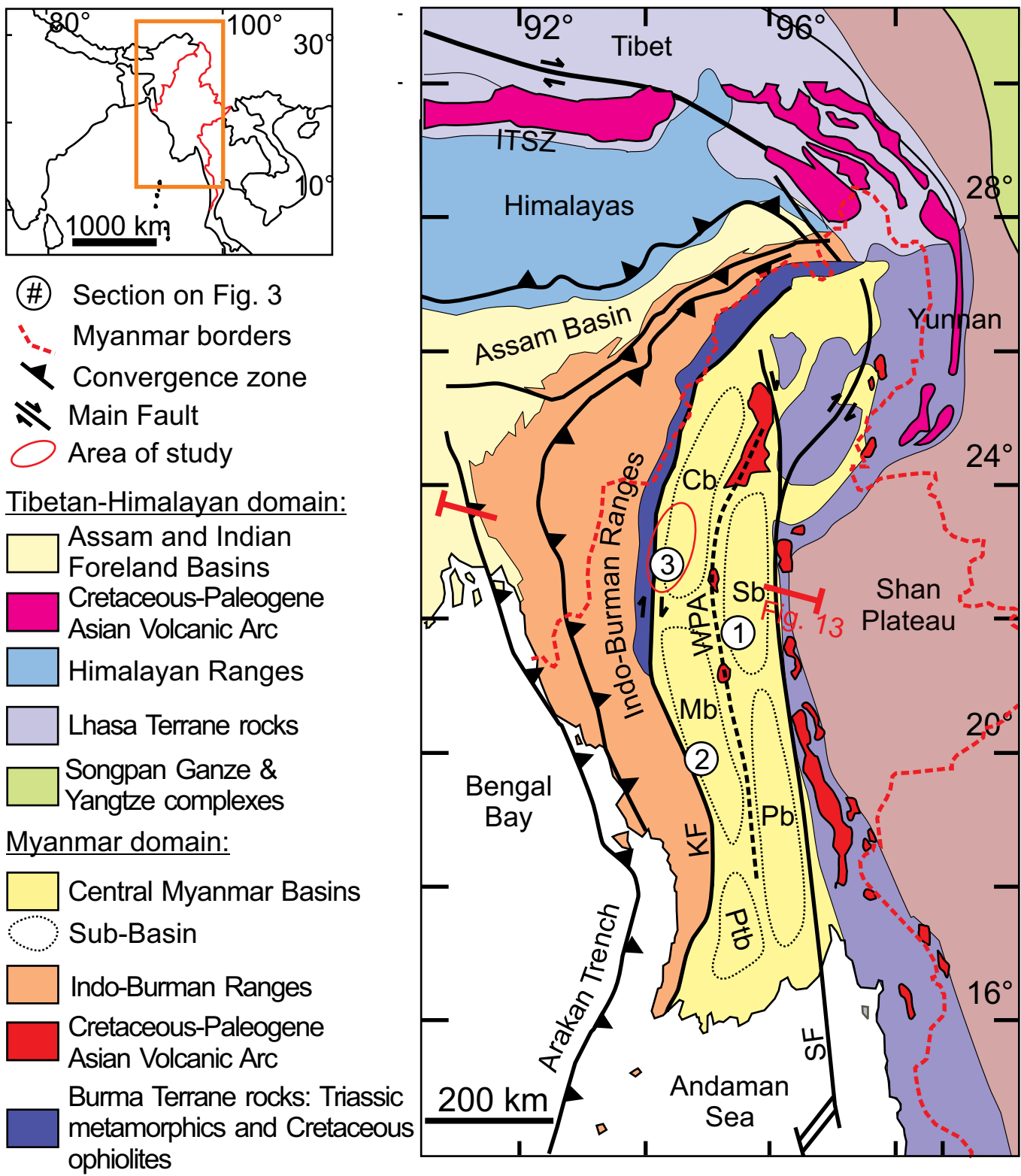

Burma Terrane rocks: Metamorphics,

Paleozoic-Jurassic Granitoids, Jurassic Ophiolites

Sibumasu Terrane rocks

Figure 2. Schematic map of the eastern Himalayan syntaxis and central Myanmar, with the main geological units, after Licht et al. (2013); boundaries between Tibetan and SE Asian terranes are not precisely drawn because they are poorly known. The approximate axis of the Wuntho-Popa Andean arc (WPA) is shown by a thick, dashed black line. The subbasins of central Myanmar are indicated with thin, dashed black lines: the Chindwin, Minbu, and Pathein basins ( $\mathrm{Cb}, \mathrm{Mb}$, and Ptb) in the forearc, the Shwebo and Pegu basins (Sb and $\mathrm{Pb}$ ) in the backarc. ITSZ-Indus-Tsangpo Suture Zone; SF-Sagaing Fault; KFKabaw Fault. Numbers in circles indicate the location of the synthetic logs in Figure 3, and the red line indicates the location of the cross section in Figure 13. Area of study is shown by a red circle. Symbol (3) sits at the location of our composite section. 
The sedimentary deposits of the forearc basin of central Myanmar provide a unique opportunity to document the paleogeography and deformation history of the Burmese subduction margin and decipher these different models. This article examines the history of the Burmese forearc basin, with a particular focus on Eocene-Oligocene times to reconstruct the evolution of the Burmese margin during the early stages of the IndiaAsia collision. Here, we report on sedimentological, geochemical, modal petrographical, and U-Pb detrital zircon geochronological data from the Chindwin Basin (northern part of the Burmese forearc basin), and integrate these results with previous data from other basins of central Myanmar to reconstruct the evolution of the Burmese margin through the Paleogene.

\section{GEOLOGICAL CONTEXT}

\subsection{The Burma Terrane and the Burmese Subduction Margin}

Myanmar can be divided into two roughly north-south-trending belts that lie on two basement blocks: central Myanmar on the Burma Terrane, and the Shan Plateau on the Sibumasu Terrane (Fig. 2). At the transition between both terranes, the deep basement of the Burma Terrane, consisting of Middle Jurassic ophiolites of the Burma-Sibumasu suture and metamorphics from the basement of the Sibumasu Terrane, is partially exposed and forms a succession of metamorphic belts (Jade Mine Belt, Slate Belt, Mogok Metamorphic Belt; Bertrand and Rangin 2003; Mitchell et al. 2007, 2012; Searle et al., 2012, 2017; Liu et al., 2016). It is not clear when the Burma Terrane collided with the Sibumasu Terrane; various unconstrained age estimates are proposed ranging from the Middle Jurassic to the latest Cretaceous, and the existence of a suture between both terranes is even challenged (Mitchell, 1993; Metcalfe, 2013; Sevastjanova et al., 2016; Liu et al., 2016; Searle et al., 2017); U-Pb zircon ages from intrusions and gneisses in the Mogok Metamorphic belt suggest a latest Jurassic-early Cretaceous age for the collision event (Mitchell et al., 2012).

The mid Cretaceous-early Paleogene tectonic evolution of Myanmar is marked by the subduction of the Neotethyan Ocean below western Myanmar along the Arakan Trench (Bender, 1983). The modern Burmese subduction margin formed as an Andean-type accretionary setting after rapid, forearc supra-subduction ophiolite spreading at ca. 125 Ma and the set-up of the Central Myanmar Basins developed in a forearc/backarc setting on the Burma Terrane (Bender, 1983; Pivnik et al., 1998; Liu et al., 2016; Zhang et al., 
2017a). The timing of this onset mirrors the evolution of the Xigaze forearc Basin in Tibet (Maffione et al., 2015; Liu et al., 2016; Wang et al., 2017). This period is marked by intense magmatic activity in the Andean-type Wuntho-Popa Arc, today represented by several large batholiths and related volcanic rocks that straddle the middle of the Central Myanmar Basins (Fig. 2; Zaw, 1990; Maury et al., 2004; Gardiner et al., 2015, 2017; Lee et al., 2016). The Wuntho-Popa Arc is commonly considered the eastern continuation of the Gangdese Arc of Tibet (Ma et al., 2013; Wang et al., 2014) and consists of widespread I-type batholiths and andesitic bodies punctuated with isolated S-type intrusions (Zhang et al., 2017b). Recently published U-Pb ages suggest a period of activity spanning from 110 to 30 Ma (Mitchell et al. 2012; Wang et al., 2014; Gardiner et al., 2015, 2017; Zhang et al., 2017b), with a main magmatic stage between 110 and 80 Ma and a subordinate magmatic stage at ca. 70-40 Ma. Cretaceous-Paleogene plutons are also present farther east along the Shan Scarp (Granitic Tin Belt of Gardiner et al., 2017) and may reflect temporary periods of eastward migration of the Andean-type arc (Gardiner et al., 2015), but their chronology and relationship with the Wuntho-Popa Arc remain poorly understood. The Burmese margin was then deformed by dextral strikeslip shear and other faulting, resulting in partitioning by pull-apart subsidence of the Central Myanmar Basins (Pivnik et al., 1998; Rangin et al., 1999) and in high-grade metamorphism in the Mogok Metamorphic Belt (Bertrand et al., 2001; Bertrand and Rangin, 2003; Barley et al., 2003; Searle et al., 2007). This strike-slip deformation regime is commonly explained as resulting from the hyper-oblique convergence of the Indian plate below the Burmese margin. As a result of this oblique convergence and subsequent deformation, central and western Myanmar were dragged northward (Socquet et al., 2006; Morley, 2009). The timing for the onset of strike-slip deformation and hyperoblique regime is not clear, but oldest $\mathrm{U}-\mathrm{Pb}$ zircon ages and $40 \mathrm{~K}-40 \mathrm{Ar}$ cooling ages of gneisses in the Mogok Metamorphic Belt indicate that high-grade metamorphism had started by the late Eocene (ca. 37-36 Ma) along a paleo "Shan Scarp Fault" following the eastern margin of the Burma Terrane (Bertrand et al., 2001; Searle et al., 2007; Morley, 2009; 2017). Two U-Pb ages in metamorphic overgrowths of zircons suggest that it might have started even earlier, by the middle Eocene (47 and $43 \mathrm{Ma}$; Barley et al., 2003). Since the middle Miocene, following the opening of the Andaman Sea between Myanmar and Sumatra, the strike-slip motion has been partitioned and accommodated by the Sagaing Fault along the Mogok Metamorphic Belt, the Kabaw Fault in the Indo- 
Burman Ranges, and the Arakan Trench (Khan and Chakraborty 2005; Socquet et al., 2006). Since then, central Myanmar has formed an individual and complex sliver plate between these two faults, the total dextral displacement of which is variously estimated at 400-500 km to more than $1000 \mathrm{~km}$ (Maung 1987; Mitchell, 1993; Socquet et al., 2006; Morley, 2009, 2017).
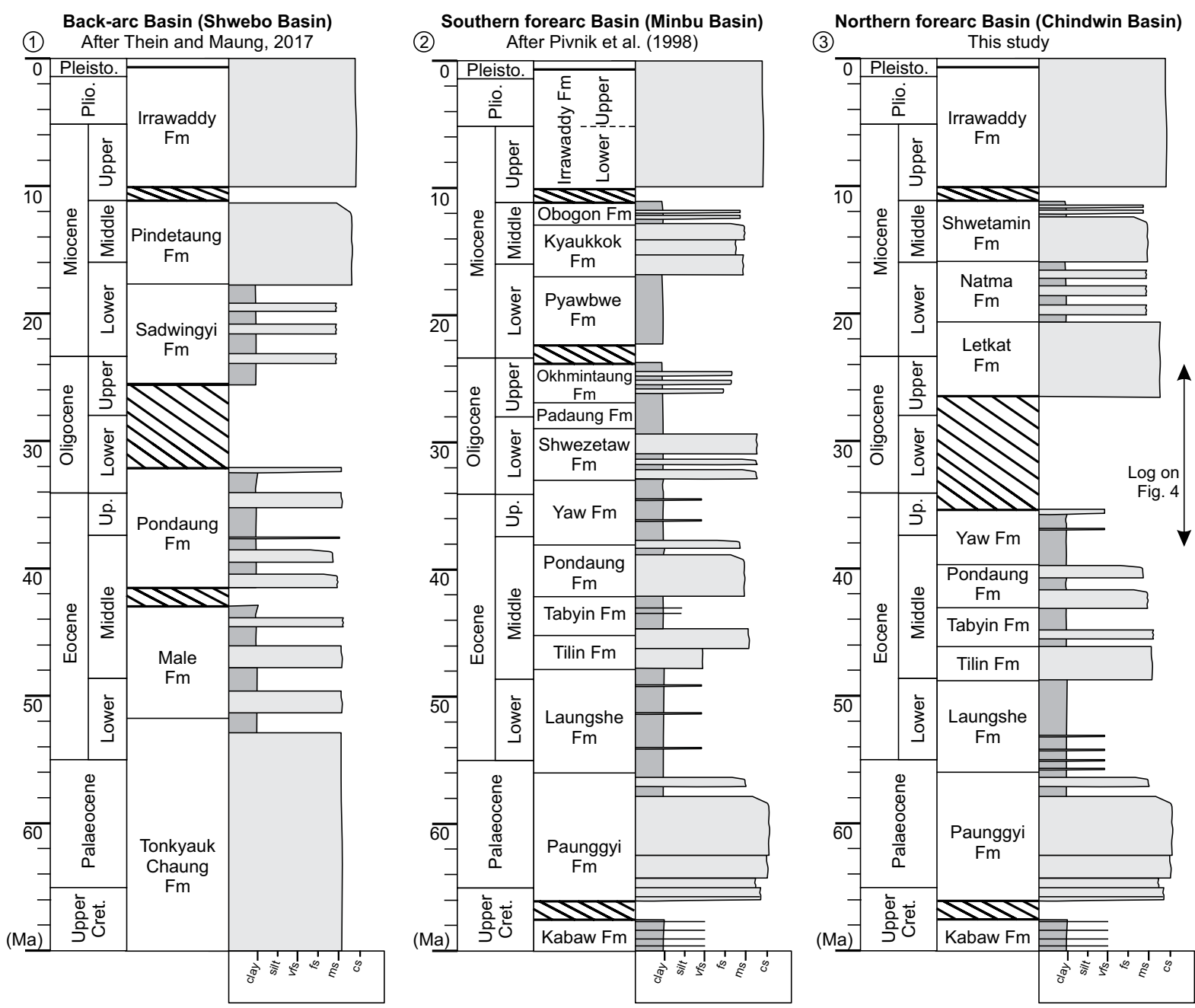

Figure 3. Synthetic logs for the three main basins of central Myanmar: (1) the Shwebo Basin in the backarc (after Thein and Maung, 2017), (2) the Minbu Basin, (southern forearc; after Pivnik et al., 1998), and (3) the Chindwin Basin (northern forearc; Bender, 1983; this study). Location of the three logs is shown on Figure 2. vfs-very fine sand; fsfine sand; ms-medium sand; cs-coarse sand.

\subsection{The Indo-Burman Ranges}

On its western margin, the Burma Terrane is separated from the Indian Foreland Basin and the Bengal Bay by the Indo-Burman Ranges, which constitute the accretionary complex produced by the Indian subduction under the Burmese active margin (Brunnschweiler, 1966; Maurin and Rangin, 2009; Bannert et al., 2011; Zhang et al., 
2017a). The Indo-Burman Ranges are divided into an outer wedge made of Neogene Himalayan-sourced clastic sequences affected by folds and thrusts, and an inner wedge mainly constituted of early Cretaceous ophiolites and Triassic schists covered by Upper Cretaceous-Eocene marine turbidites (see also Figure 13C; Maurin and Rangin, 2009; Bannert et al., 2011). The origin of the Triassic schists is still unclear, but they may belong to a micro-continent accreted and thrusted on the Burmese margin between 125 and 110 Ma (Morley, 2012), or be part of the pre-Jurassic Burma Terrane basement that was dismantled after supra-subduction spreading of the forearc (Sevastjanova et al., 2016). The oldest Cretaceous marine turbidites overlying the Triassic schists in the Indo-Burman Ranges are dated to the Campanian, but some deposits contain allochthonous blocks of Albian limestones (Bender, 1983). The outer wedge experienced uplift starting in the late Miocene as a consequence of either increased and potentially faster subduction of sediment from the Bengal Basin and Syllet Trough on the Indian Plate (Maurin and Rangin, 2009) or westward crustal flow from southeastern Tibet resulting in E-W shortening on the Burma Terrane (Rangin et al., 2013). The structure, timing of uplift, and emergence of the inner wedge remain poorly understood.

The most common view is that the inner wedge was exhumed during an early episode of accretionary building along the Burmese active margin, either during the early Cretaceous (Liu et al., 2016; Zhang et al., 2017a) or Late Cretaceous-Paleogene (Bender, 1983; Socquet et al., 2002). Acharyya (2007, 2015) and Metcalfe (2013) proposed that the early uplift of the inner wedge was caused by the accretion of individual island arc fragments that accreted along the Burmese margin during the Paleogene, but evidence for these island arc fragments in the inner wedge is lacking. Nielsen et al. (2004) and Maurin and Rangin (2009) argue that the inner wedge is more complex than a simple accretionary wedge; the core of the inner wedge follows a N-S strike-slip fault system and displays a positive flower structure, similar to retro-wedges formed along hyperoblique convergence zones (Burbidge and Braun, 1998; McClay et al., 2004; Leever et al., 2011). Today, the inner wedge fault system is traversed by the Kabaw strike-slip fault system and accommodates a significant component $(1 / 4-1 / 3)$ of the $\mathrm{N}-\mathrm{S}$ strike slip deformation of the Burma Terrane (Nielsen et al., 2004; Socquet et al., 2006). 


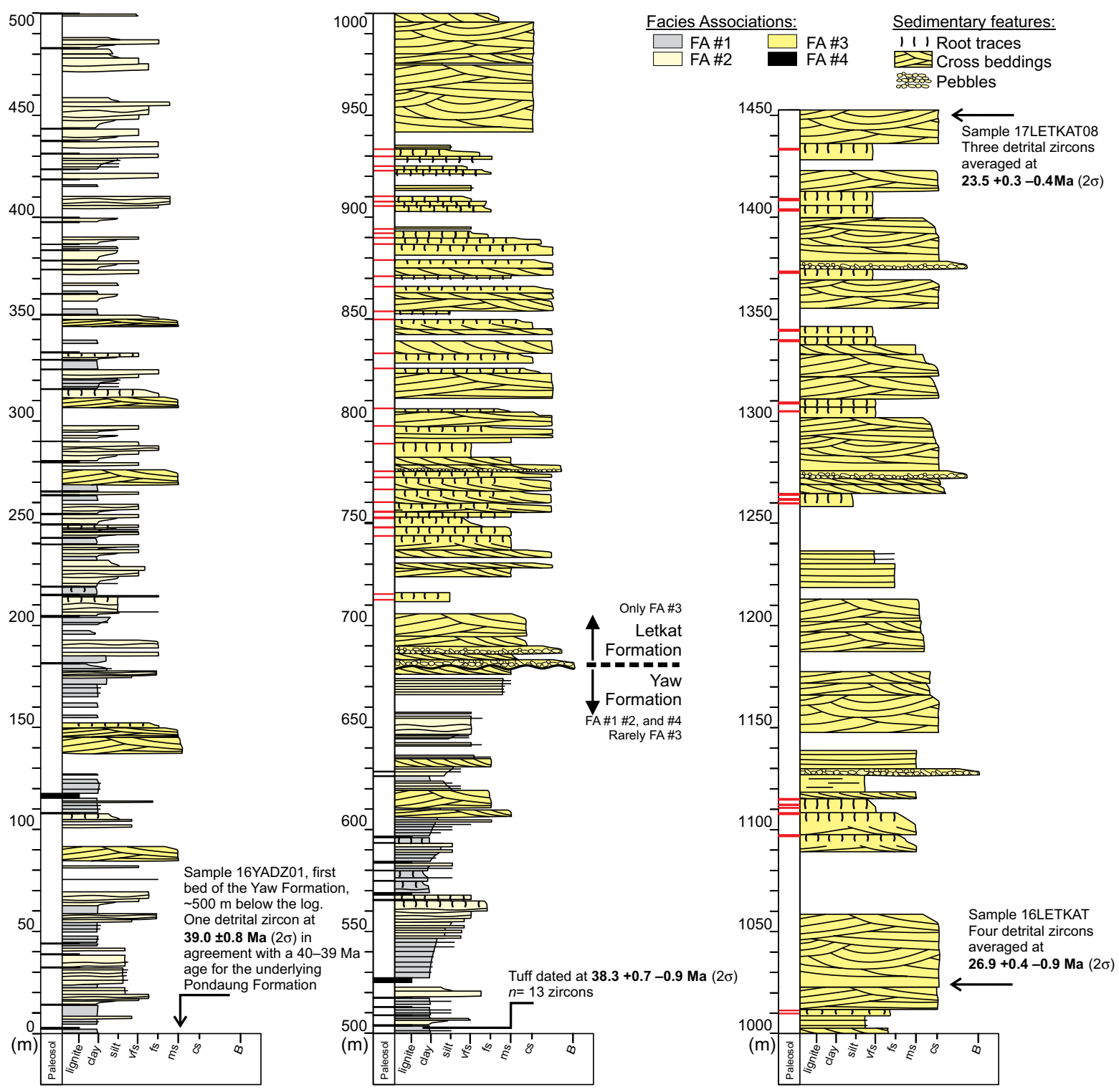

Figure 4. Composite log of the upper part of the Yaw Formation and lower part of the Letkat Formation, Chindwin Basin, with their facies associations (description in Table 1). Maximum depositional ages for our sandstone samples and age of the Tuff layer dated in this study are also shown. In the Paleosol column, black lines indicate histosols whereas red lines indicate ultisols. vfs-very fine sand; $f s$-fine sand; $m s-m e d i u m$ sand; $c s$-coarse sand; B-Boulder.

A combined petrographic and isotopic study of Paleogene marine turbidites from the inner wedge of the Arakan Yoma (southern edge of the Indo-Burman Ranges) identified a persistent youngest zircon-fission track population of $37 \mathrm{Ma}$ in the sandstones (Allen et al. 2008). It is not clear if this fission-track age reflects a volcanic age-thus giving a maximum age for the deposition of the last flysch in the accretionary prism, suggesting that the inner wedge was emerged quickly thereafter-or if this age has been reset and 
reflects an episode of exhumation, indicating that the inner wedge was getting uplifted at that time. Both interpretations suggest a first, late Eocene uplift for the Indo-Burman Ranges. In addition, sedimentary provenance databased on $\mathrm{Nd}$ and $\mathrm{Sr}$ isotopes of late Paleogene units in the Central Myanmar Basin suggests that the Indo-Burman Ranges emerged in the early Oligocene (Licht et al., 2013, 2016). However, the precise timing of uplift and its mechanisms remain unknown.
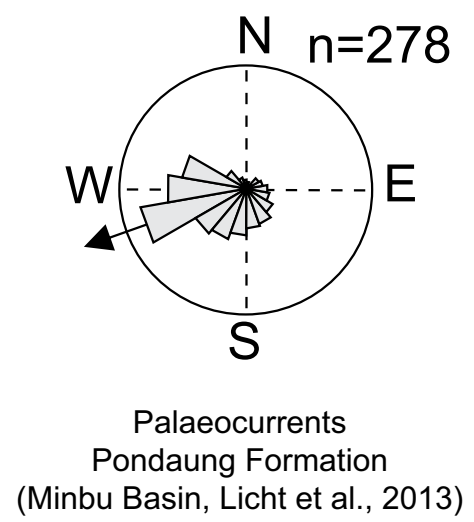

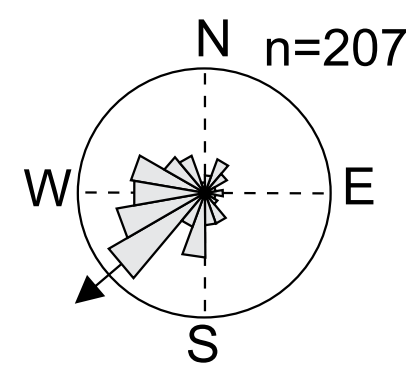

Palaeocurrents Yaw Formation (Chindwin Basin)

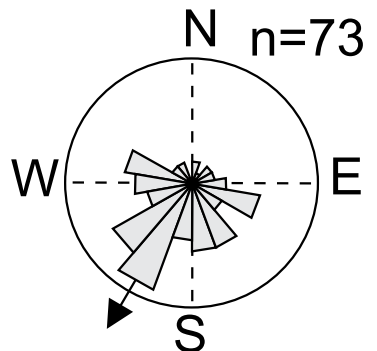

Palaeocurrents Letkat Formation (Chindwin Basin)

Figure 5. Paleocurrents for the Pondaung Formation in the Minbu Basin (after Licht et al., 2013), the Yaw Formation in the Chindwin Basin (including new measurements and data from Licht et al., 2013), and the Letkat Formation in the Chindwin Basin (this study). Palaeocurrent directions were measured on 3-D exposures of trough cross-beddings (facies St, Table 1).

\subsection{The Burmese Forearc and Backarc Basins}

The Central Myanmar Basins comprise two N-S-trending lateral troughs of Late Cretaceous-Cenozoic sub-basins, located both east (in a backarc position) and west (in a forearc position) of the Wuntho-Popa Arc.

The backarc basin of central Myanmar itself comprises two sub-basins, the Shwebo Basin to the north and the Pegu Basin to the south (Bender, 1983). Deposits overlie basement rocks constituted of Mesozoic marine turbidites and metamorphics and Middle Jurassic ophiolitic material (Morley, 2017; Searle et al., 2017). The sedimentary sequence starts with Upper Cretaceous-middle Eocene conglomerates, volcaniclastics, and sandstones of the Tonkyauk Chaung and Male Formations, followed by the upper Eocene-lowermost Oligocene Pondaung Formation (Fig. 3A; Thein and Maung, 2017; Zhang et al., 2017b). The Paleogene deposits of the Shwebo Basin are exclusively continental (Thein and Maung, 2017); it is not known whether the deposits in the Pegu 
Basin are marine or freshwater. and constitutes a local (and recent) topographic high (Bender, 1983).
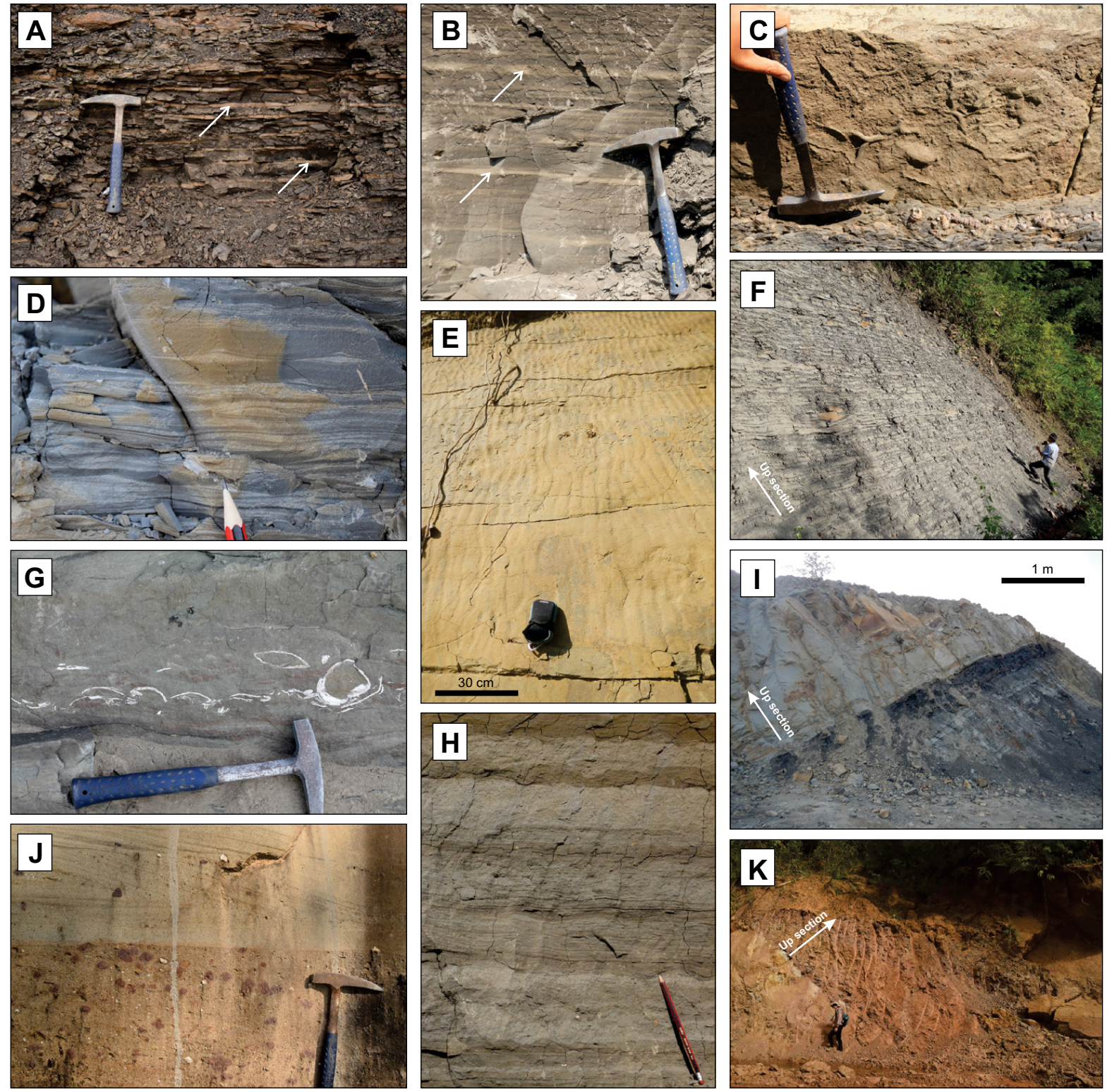

Figure 6. (A) and (B): black mudstones with $\mathrm{cm}$ thick siderite beds, shown by white arrows (facies Ls/Fm). (C) Trace fossil Thalassinoides in siltstone beds (facies Sw). (D) Wavy bedding with symmetrical cross-laminations (facies $S w$ ). (E) Bed of symmetrical ripples in facies $S w$ (typical of wave-formed ripples) viewed from above. (F) Thick accumulation of wavy and flaser bedding (facies $S w$ ). (G) Unionid fossils in massive very fine sandstone (facies Ssm). (H) Wavy and flaser bedding with planar laminations and asymmetrical cross-laminations (facies Sw). (I) Meter-thick lignite (facies Cv) overlain by a sandstone body of facies St. (J) Trough cross-bedding (facies St) rich in reworked, oxidized sedimentary clasts in the Letkat Formation. (K) Pedogenised sandstones and mudstones (facies Sm) in the Letkat Formation. When the scale is not displayed, rock hammers, pencils, and humans can be used for scale. 
The Paleogene sequence ends with a major Oligocene (?) unconformity observable in seismic lines (Zhang et al., 2017b). Neogene deposits consist of southward prograding tidal-influenced estuarine sequences: the Sadwingyi and Pindetaung Formations in the Shwebo Basin, and the Taungtalon, Moza, and Khabo Formations in the Pegu Basin (Khin and Myitta, 1999). These formations are unconformably overlain by the late middle Miocene-Quaternary fluviatile Irrawaddy Formation (Pivnik et al., 1998; Chavasseau et al., 2006). The Pegu Basin has been inverted and uplifted since the late Miocene The forearc basin of central Myanmar comprises two major sub-basins, the Chindwin Basin to the north and the Minbu (also called Salin) Basin to the south. These basins are separated today by the Pondaung Ranges, a small topographic high at $\sim 22^{\circ} \mathrm{N}$ latitude where Paleogene units crop out (Bender, 1983; Pivnik et al., 1998; MGS, 2014). These two sub-basins have also been subdivided into smaller basins by previous authors (including the Pathein Sub-basin to the south; e.g., Bender, 1983) but we will keep things simple and refer only to the two main basins. On the western margin of both basins, supra-subduction ophiolites of the forearc basement crop out along a narrow window stretching along the east side of the Indo-Burman Ranges, and are presumably directly overlain by sedimentary deposits (Liu et al., 2016). On the basins' eastern edges, sediments onlap granitic rocks of the Wuntho-Popa Arc (Zhang et al., 2017b). The Cretaceous-early Cenozoic depositional history is largely similar in both sub-basins. The sequence starts with the poorly exposed Kabaw Formation, constituted of marine limestones and mudstones spanning from the Albian to the Maastrichtian (Figs. 3B and 3C; Bender, 1983). The early Cenozoic sequence includes the Paunggyi, Laungshe, Tilin, and Tabyin Formations spanning from the latest Maastrichtian (?) to the middle Eocene (Nagappa, 1959), all of which consist of shallow-marine siliciclastics with rare continental episodes (Bender, 1983). These units are only differentiated by their dominant grain-size (sandstone or mudstone); their lithostratigraphic boundaries remain vague. The late middle Eocene Pondaung Formation, present in both basins (and here older than in the backarc basin), is the only unit that has received considerable attention, because of its prolific mammalian faunal and paleobotanical remains (e.g., Jaeger et al., 1999; Chaimanee et al., 2012; Licht et al., 2014a, 2015). The Pondaung Formation reflects westward directed fluvio-deltaic systems, the upper member of which is continental with carbonate-bearing paleosols, stacked channels, fossil vertebrates, and freshwater gastropods (Licht et al., 2013, 2014b, 2014c). In the Minbu 
Basin, the fossiliferous upper member is precisely dated at ca. 40-39 Ma via a combination of magnetostratigraphy, biostratigraphy, and geochronology (see review of dating results in Licht et al., 2015).

The late middle Eocene-upper Eocene Yaw Formation of central Myanmar represents a period of significant changes in Burmese stratigraphy, with the first pieces of evidence for differentiation between the Minbu and Chindwin Basins. In the Minbu Basin, the Yaw Formation only comprises shallow-marine, fine-grained nummulite-bearing deposits (Nagappa, 1959; Adnet et al., 2008); in the Chindwin Basin, the lithofacies of the Yaw Formation are more varied, with evidence for marine intervals, freshwater gastropods, and lignites yielding continental vertebrates (Licht et al., 2013, 2014c).

Subsequent younger geological units are significantly different in both basins (Figs. 3B and 3C). In the Minbu Basin, the Yaw Formation is followed by the Shwezetaw, Padaung, and Okhmintaung Formations, which all yield shallow-marine Oligocene gastropods, bivalves, and foraminifera (Bender, 1983). Gough and Hall (2017) recently interpreted these units as representing southwards-trending deltaic systems; once again, the boundaries of these units are lithologically based and often vague. They are followed by the lower to middle Miocene fluvio-deltaic Pyawbwe, Kyaukkok, and Obogon Formations (Bender, 1983) that are overlain by the fluviatile late middle MiocenePliocene Irrawaddy Formation (Bender, 1983; Chavasseau et al., 2006, 2010). In the Chindwin Basin, the Yaw Formation is overlain by the Letkat Formation, an $\sim 1.5-\mathrm{km}$ thick sequence of afossiliferous fluviatile sandstones (United Nations, 1978). Some authors have proposed that the contact between the Letkat and the Yaw Formation is unconformable and that the Oligocene is missing in the Chindwin Basin (United Nations, 1978; Wang et al., 2014), whereas Bender (1983) proposes a conformable contact and indicates the presence of undescribed Oligocene sporomorphs in the Letkat Formation. The Letkat Formation is overlain by the afossiliferous fluviatile Natma and Shwetamin Formations of hypothetical Miocene age (United Nations, 1978; Bender, 1983) that are eventually unconformably overlain by the same fluviatile Irrawaddy Formation found in the Minbu Basin.

\section{METHODS}

\subsection{Sedimentology and Stratigraphy}

To determine the Paleogene evolution of the Burmese forearc basin, we explored and described deposits along a $\sim 100 \mathrm{~km}$ north-south-trending portion of the Chindwin 
Basin in the rainshadow of the Indo-Burman Ranges. We started south of the city of Kalewa and continued up to the north of the city of Mawlaik, with a particular focus on the middle Eocene-Oligocene Pondaung, Yaw, and Letkat Formations (Fig. 2). Additionally, we measured a composite section spanning the Yaw and Letkat Formations, composed of five stratigraphic sections correlated in the field (distance between sections is $\sim 200-2000 \mathrm{~m}$ ). The location of the composite section is indicated on Figure 2. Detailed logs are available in Figure DR11, and are combined into a composite log in Figure 4. We described the sedimentary facies of these two formations, classified them into ten lithofacies adapted from the classification of Miall (2013), and grouped them into four facies associations (Table 1). Finally, we measured paleoflow directions on 3-D outcrops of sandstone trough cross-bedding (facies "St" of Table 1) according to standard field methods (Collinson et al., 2006); results are displayed on Figure 5.

\subsection{Sulfur Isotope Analysis}

Employing a common way to distinguish brackish from freshwater swamp deposits (Casagrande, 1987), lignite samples from the Yaw Formation were crushed and weighted for sulfur content and isotopic composition (measured as $\delta 34 \mathrm{~S}$ in $\%$ relative to the VCDT [Vienna Canyon Diablo Troilite] standard). Weighted samples were flash combusted at $1000{ }^{\circ} \mathrm{C}$ with excess oxygen in a Eurovector Elemental Analyzer (EA) equipped with a Costech zero-blank autosampler, and connected to a ThermoFinnigan MAT253 isotope ratio mass spectrometer for measurement of $\delta 34 S$. Internal laboratory reference materials were interspersed with samples for a two-point calibration, allowing for conversion to the $\delta 34 \mathrm{~S}$ VCDT scale and estimations of total sulfur content (see also Fry et al., 2002).

\subsection{Sandstone Petrography and U-Pb Dating}

Medium-grained sandstone samples were collected along our composite section for petrological and geochronological analyses. Thin sections of 13 sandstone samples were prepared and counted according to the Gazzi-Dickinson method to determine their quartz, feldspar and lithic grains content (Dickinson, 1985); 300-350 grains were counted per section. Detailed results and stratigraphic location of the samples are available in Table DR2 (see footnote 1).

Paleogene sedimentary rocks below and along our composite section were sampled for $\mathrm{U}-\mathrm{Pb}$ dating of zircons, including one sample from the Paleocene Paunggyi Formation, 
two sandstones and one tuff from the Yaw Formation and four sandstones from the Letkat Formation. Detailed analytical protocols and information about the data reduction schemes are provided in the supplementary methods. Briefly, zircon crystals were extracted by traditional methods of heavy mineral separation, including concentration with a Holman-Wilfley gravity shaking table, density separation with methylene iodide and magnetic separation with a Frantz Magnetic separator. U-Pb ages were generated using laser-ablation-inductively coupled plasma-mass spectrometry (LA-ICP-MS), using an iCAP RQ Quadrupole ICP-MS coupled to an Analyte G2 excimer laser at the University of Washington, using a spot diameter of 25 microns. Data reduction was conducted with Iolite, using their Geochron Data Reduction Scheme to calculate U-Pb ages uncorrected for common lead (Paton et al., 2010), and with the Andersen Routine of the Vizualage Data Reduction Scheme (Chew et al., 2014) for U-Pb ages corrected for common lead. Both approaches yielded quasi-identical zircon ages in our data set, and ages used in this manuscript are uncorrected for common lead. Detailed location, stratigraphic level, and U-Pb data are available in Table DR3 (see footnote 1). Stratigraphic locations for the Yaw and Letkat Formation samples are also indicated on Figure 4. Maximum depositional age for detrital samples and crystallization age for volcanic samples with multiple zircon ages were calculated using Tuffzirc (Ludwig, 2003) and are also displayed on Figure 4. The final age error calculated for each sample is the quadratic sum of the uncertainty of Tuffzirc age calculation and of the systematic uncertainty during each session $(\sim 1.3 \%)$.

\section{RESULTS}

\subsection{Sedimentology of the Eocene and Oligocene Deposits in the}

\section{Chindwin Basin}

Deposits and associated lithofacies of the Pondaung Formation are identical to those in the Minbu Basin farther south and have already been extensively described in Licht et al. (2014b); in the southernmost part of the Chindwin Basin, they have also been described by Oo et al. (2015). Briefly, the formation mainly consists of large, coarse-grained, sandstone bodies, 2-18 m thick, >100 m wide and are dominated by large sets (up to 1 $\mathrm{m}$ thick) of trough cross-bedding. The sandstone bodies are interfingered with finegrained sequences, with pedogenised heterolithic deposits and extensive paleosolbearing mudstone successions. Paleosols display vertic features and pedogenic nodules, as well as different stages of hydromorphic development, and were identified as 
hydromorphic vertisols. In the Minbu Basin, these deposits have yielded a mix of freshwater riparian and brackish water mangrove trees (Licht et al., 2014a, 2015), continental vertebrates (Jaeger et a., 1999; Chaimanee et al., 2012), freshwater gastropods (Licht et al., 2014c), and occasional seawater fishes (Adnet et al., 2008). Paleocurrent measurements indicate an unequivocal westward flow (Fig. 5).

Our 1450 m composite sedimentary log of the Yaw and Letkat Formations is displayed in Figure 4 . The sedimentary log starts $\sim 500 \mathrm{~m}$ above the transition from the Pondaung Formation to the Yaw Formation, which is marked by the first occurrence of lignites and black mudstones. The log ends $\sim 700 \mathrm{~m}$ below the transition from the Letkat to the Natma Formation, which is marked by a significant increase in fine-grained deposits (United Nations, 1978). In total, the thickness of the Yaw Formation is estimated to be around $\sim 1000 \mathrm{~m}$, and the Letkat Formation to be around $\sim 1500 \mathrm{~m}$.

Deposits of the Yaw Formation display ten lithofacies that can be divided into four facies associations (Table 1). Facies association FA1 is mainly made of massive black mudstones (Fm) interfingered either with siderite beds (Ls/Fm; Figs. 6A and 6B) or thinly planar laminated siltstones (Fs/Fm). Facies association FA2 is more diverse and is mainly composed of beds of siltstone to very fine sandstone showing planar laminations, small planar cross-laminations, and symmetrical cross-laminations with bundled and chevron upbuilding typical of wave-formed cross-laminations (Nichols, 2009). These fine-grained beds are sometimes interfingered with gray mudstones, forming flaser, lenticular, and wavy beddings (facies Sw); these interfingered beddings can contain trace fossils of Thalassinoides and Skolithos (Figs. 6C to 6H). More commonly, these beds show evidence for partial mixing and rootlets, and yield amber, fish bones, freshwater gastropods (thiarids; Licht et al., 2013) and unionid bivalves (facies Ssm; Fig. 6G). Sapropelic lignites rich in plant debris (facies Cs) also occur in sequences of facies Sw and Ssm, together with sequences of coarser, cross-laminated sandstones that are also rich in plant debris and occur in thick (commonly $>1 \mathrm{~m}$ ) tabular sets (facies $\mathrm{Sp}$ ). 
TABLE 1.

LITHOFACIES AND FACIES ASSOCIATIONS IDENTIFIED IN THE YAW AND LETKAT FORMATIONS, CHINDWIN BASIN

\begin{tabular}{|c|c|c|}
\hline Facies & Description & Interpretation \\
\hline \multicolumn{3}{|c|}{ Facies association FA1 } \\
\hline $\mathrm{Fm}$ & $\begin{array}{l}\text { Massive black mudstones; sets of } 10 \mathrm{~cm} \text { to } 2 \mathrm{~m} \text {; rare preserved } \\
\text { planar laminations with millimeter spacing. }\end{array}$ & $\begin{array}{l}\text { Settling in subaqueous anoxing } \\
\text { conditions, below depth of } \\
\text { wave action }\end{array}$ \\
\hline $\mathrm{Fs} / \mathrm{Fm}$ & $\begin{array}{l}\text { Grey siltstones, either showing planar laminations or small planar } \\
\text { cross-lamination }(<1 \mathrm{~cm}) \text {; occurring in small sets }(<5 \mathrm{~cm}) ; \\
\text { interfingered with thicker sets of massive black mudstones. }\end{array}$ & $\begin{array}{l}\text { Settling in subaqueous anoxing } \\
\text { conditions, close to the depth } \\
\text { of wave action }\end{array}$ \\
\hline Ls/Fm & $\begin{array}{l}\text { Siderite beds; nodular or continuous; } 5-20 \mathrm{~cm} \text { thick. Always } \\
\text { interfingered with thicker sets of black mudstones, creating } \\
\text { apparent cycling mudstone/siderite alternations. }\end{array}$ & $\begin{array}{l}\text { Post-depositional mineralization } \\
\text { in subaqueous anoxic } \\
\text { conditions }\end{array}$ \\
\hline
\end{tabular}

Facies association FA2

Sw Heterolithic facies dominantly made of siltstones to very fine sandstones forming either climbing ripple cross-laminations, symmetrical cross-laminations with bundled and chevron upbuilding, or wavy laminations. Set thickness varies from 5 to $40 \mathrm{~cm}$, with undulating bounding surfaces, and interfingered with grey mudstone beds forming flaser, lenticular, or wavy beddings. In rare places, display trace fossils Thalassinoides and Skolithos.

Ssm Dark-grey siltstones to very fine sandstones, occurring in sets of $20 \mathrm{~cm}$ to $4 \mathrm{~m}$. commonly structureless and mixed with mud, but can sometime show either planar lanimations, small $(<3 \mathrm{~cm})$ trough cross-laminations, symmetrical cross-laminations with bundled and chevron upbuilding. Yield amber; fish bones; freshwater gastropods and bivalves; rich in plant debris. Show sometimes rootlets.

Cs Sapropelic lignite, 5-50 cm thick, made of thinly laminated organic debris, interfingered with millimeter-thick layers of silt to very fine sand.

$\mathrm{Sp} \quad$ Very fine to fine sandstones occurring in $20 \mathrm{~cm}$ to $4 \mathrm{~m}$ thick beds of small $(3-15 \mathrm{~cm})$ sets made of horizontal laminations, planar or trough cross-laminations. Rich in plant debris; can be rich in gastropods.

Facies association FA3

St Fine to gravelly sandstones in $50 \mathrm{~cm}$ to $2 \mathrm{~m}$ sets of trough crosslaminations. Occurs in cosets of 2 to 5 sets, arranged in wingshaped bodies that can be 10 to 100 s of meters wide. Erosive lower bounding surface, sometimes accompanied with a $5-30 \mathrm{~cm}$ lag of mud clast breccias, conglomerates, rounded fossil bones, and fossil wood. Commonly rich in plant debris. Uppermost sets commonly show evidence of pedogenic development.

$\mathrm{Sm} \quad$ Very fine to coarse structureless, massive sandstones, in $50 \mathrm{~cm}$ to $4 \mathrm{~m}$ thick beds commonly overlying cosets of facies St. Mud matrix, dominantly red to brown, with green to blue mottles and rare pedogenic nodules.

Facies association FA4

$\mathrm{Cv}$ Massive lignite, laterally extensive, $20 \mathrm{~cm}$ to $2 \mathrm{~m}$, commonly capping cosets of facies Sw, Ssm, or St. In some locations yields lignified fossil trunks, turtle plates, and continental vertebrates.

Tidal flats

Coastal marsh

Delta front deposits of a bayhead delta

Distributary mouth, bay-head delta

River channel

Pedogenised overbank

Swamp

Facies association FA3 is dominated by facies St, which consists of fine to coarse sandstones organized in meter-thick sets of trough cross-stratifications. These sets commonly occur in cosets of 3-5 sets, have an erosional base, and occasionally have a 
basal lag full of mud-clast breccias and plant debris. These cosets occur in wide (sometimes $>200 \mathrm{~m}$ ) bodies that decrease in grain-size near their wings. In the area of Mawlaik, $\sim 100 \mathrm{~km}$ north of Kalewa, sandstones are occasionally capped by structureless, pedogenised sandy beds mixed with a mudstone matrix, displaying a dominant brownish color, green mottles, sparse slickensides, and pedogenic nodules (facies Sm). This facies has, as of yet, only been observed in the uppermost layers of the Yaw Formation preceding the transition to the Letkat Formation. Finally, facies association FA4 is made of a single facies $\mathrm{Cv}$, constituted of thick (up to $2 \mathrm{~m}$ ), massive lignites that yield lignified fossil trunks and occasional vertebrate remains (Fig. 6I).

The four facies associations alternate following regular coarsening-upward cyclothems (FA1 to FA3) capped by lignites (FA4). FA3 is relatively rare and FA4 lignites can cap a smaller, FA1-FA2 sequence. The last $100 \mathrm{~m}$ of the Yaw Formation follows an overall coarsening upward sequence and FA3 sandstones become more common. The same facies associations can be found over the $100 \mathrm{~km} \mathrm{~N}-\mathrm{S}$ area we investigated; lignite beds can be tracked over distances greater than $10 \mathrm{~km}$ and are currently mined for coal production. Palaeocurrents measured in FA3 trough crossbeds (facies St) cover a broad range of directions from $\mathrm{S}$ to $\mathrm{WNW}$, with an average direction toward the southwest (Fig. 5).

There is no obvious angular unconformity at the contact between the Yaw Formation and Letkat Formation, but this contact is sharp, marked by the occurrence of several sandstones bodies with thick ( $>2 \mathrm{~m}$ ) basal lags made of blocks of reworked sediment, altered siderite, and lignified fossil trunks (Fig. 6J). The Letkat Formation is only constituted of FA3. Facies St is commonly coarser than the sandstone beds observed in the Yaw Formation, and can be associated with gravels, silicified fossil trunks, and rounded vertebrate bones. We did not observe any inclined heterolithic stratification in the sandstone bodies; cosets of facies St are commonly occurring in wide (tens of meters) tabular or wing-shaped bodies. Facies Sm is also more present, usually capping 10-15 m cosets of facies St. Pedogenic features are different from what is found in the Pondaung and Yaw Formations; pedogenic nodules are rare, mottles are dominantly reddish or yellow, sometime root-shaped, and form well developed, 1-3-m-thick paleosol profiles, with increasing mottling and mixing upward resembling modern Ultisols (Fig. 6K). The first $200 \mathrm{~m}$ of the Formation are particularly coarse, with gravel beds made of rounded quartz being common. Gravels disappear after $\sim 250 \mathrm{~m}$, and most 
of the remaining deposit is made of coarse St sandstones with occasional pedogenised Sm beds. Palaeocurrents measured in FA3 trough crossbeds (facies St) cover a broad range of directions from $\mathrm{W}$ to $\mathrm{E}$, with an average direction toward the south-southwest.

\subsection{Sulfur Content and Isotopic Composition}

Lignites sampled for sulfur analysis can be grouped into two families (Fig. 7). A first family, with a low amount of sulfur $(\sim<0.8 \%)$ and a narrow range of $\delta 34 \mathrm{~S}$ values, between -2 and $+12 \%$ VCDT, corresponds to the values found in modern freshwater peats, where sulfur is particularly limited and mostly comes from plant sulfates (Casagrande, 1987). The second family display a much broader range of sulfur amount (up to $5 \%$ ) and varying sulfur isotopic composition, from -10 to $+20 \%$ o VCDT, similar to those of peats formed under brackish water influence where regular inputs of seawater sulfate increases the availability of sulfur for bacterial reduction (Casagrande, 1987).

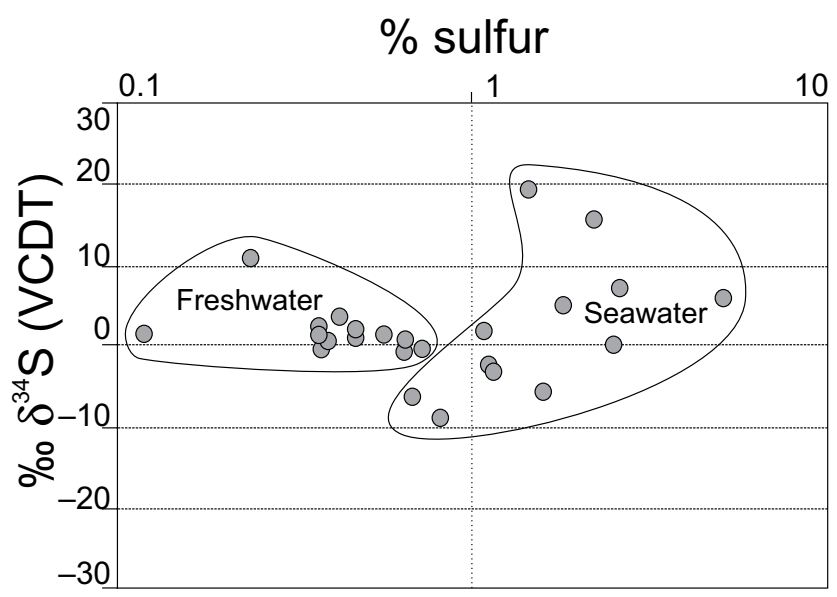

Figure 7. Percentage of sulfur and sulfur isotopic composition (expressed in \%o of deviation from the VCDT [Vienna Canyon Diablo Troilite] international standard) in lignites of the Yaw Formation. Values form two distinct families: one with low amount of sulfur (<1\%) and a homogeneous sulfur isotopic composition, around 2\%o VCDT, and one with a wide array of sulfur content (up to 5\%) and isotopic compositions ( 6 to $+6 \%$ o VCDT).

\subsection{Sedimentary Provenance of the Paleogene Units}

Sandstone grain-counting results are plotted on Q-F-L and Lm-Lv-Ls diagrams (Fig. 8) and compiled with previous data from Paleocene to middle Eocene units in the same section (Paunggyi, Tilin, and Pondaung Formations; Wang et al., 2014). Paleocene to middle Eocene sandstones are volcanic-rich, litharenitic and display similar grain- 
counting results to those of the Paleogene turbidite sample from the Indo-Burman Ranges of Allen et al. (2008). By contrast, the Letkat Formation is dominated by volcanic-depleted quartzarenites. Sandstones from the Yaw Formation display intermediate features between both end-members. This evolution follows the same long-term pattern as sandstones in the nearby Minbu Basin (Licht et al., 2016). Eocene sandstones in the Minbu Basin are much poorer in volcanic lithics compared to the Chindwin Basin; only Miocene sandstones are purely quartzarenitic, plotting in the same area as Letkat sandstones on the QFL ternary diagram (Fig. 8). Carbonate lithic fragments were detected in insignificant proportions in all samples, as is also observed in the Minbu Basin $(<1 \%)$.

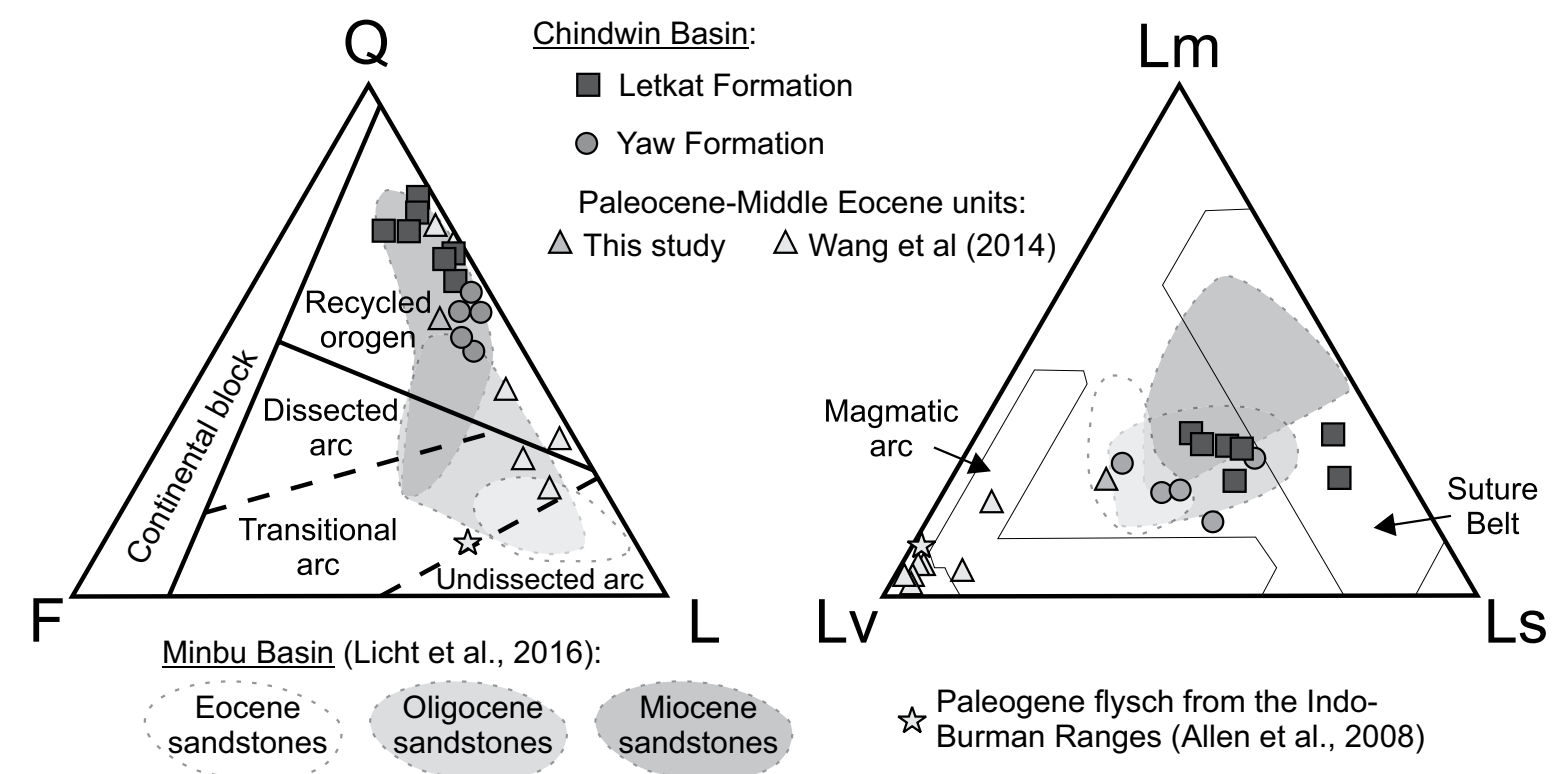

Figure 8. QFL and LvLsLm plots of the Letkat Formation, Yaw Formation, and Paleocenemiddle Eocene units from the Chindwin Basin (data from Wang et al., 2014, and this study), compared with Eocene to Miocene sandstones from the Minbu Basin (Licht et al., 2016) and a Paleogene turbidite from the Indo-Burman Ranges (Allen et al., 2008). Main provenance provinces following Dickinson (1985). Q-quartz; F-feldspar; L-lithic fragments; Lm-metamorphic; Ls-sedimentary; Lv-volcanic.

Kernel density estimates (KDE) and age histograms of U-Pb age distributions of individual samples are shown in Figure DR2 (see footnote 1); individual samples are also compared with other samples from the forearc and backarc basin of central Myanmar on a multidimensional scaling map (MDS; Fig. 9). An MDS is a visual way to assess the misfit between age distributions using the Kolmogorov-Smirnov (KS) statistic 
as the dissimilarity measure (Vermeesch, 2013). Ages from individual samples are grouped with previous samples of the Chindwin Basin from Wang et al. (2014) into three groups on Figure 10: Paleocene to middle Eocene units $(n=601$ from six samples, including five samples from the Paunggyi, Tilin, and Pondaung Formations by Wang et al., 2014), the Yaw Formation ( $n=202$, from two samples), and the Letkat Formation ( $=470$ from five samples, including one sample from Wang et al., 2014).

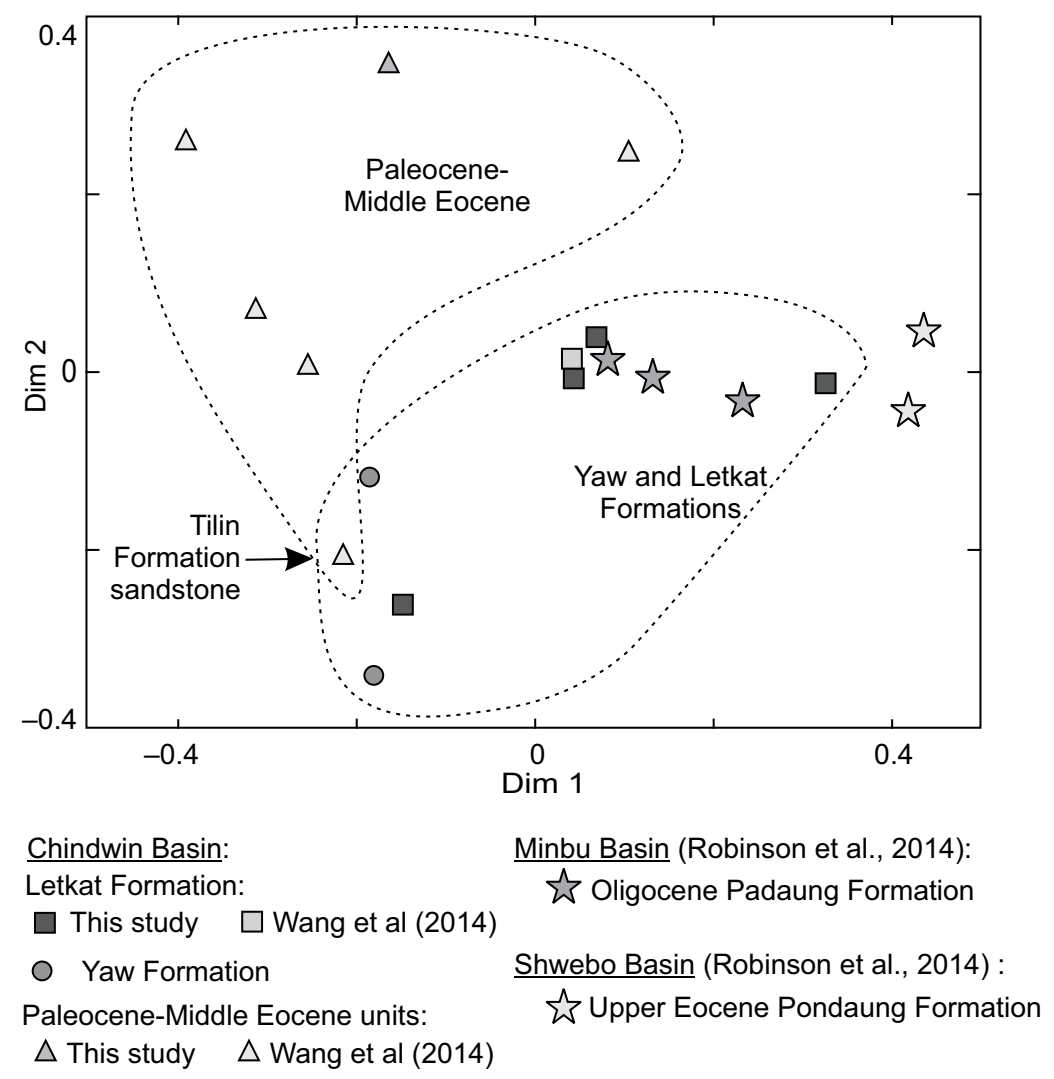

Figure 9. Multidimensional scaling map showing the dissimilarities between individual samples of this study and previously published samples (Wang et al., 2014; Robinson et al., 2014). Axes are in dimensionless "KeS units" $(-1<K S<1)$ of dissimilarity between samples. Final "stress" value is 0.06, indicating a fit between "good" and "fair" (Vermeesch, 2013). Ranges of variation for individual samples of Paleocene-middle Eocene and younger deposits from the forearc basin are highlighted by dashed lines.

Paleocene to middle Eocene sandstones from the Chindwin Basin are dominated by Late Cretaceous (ca. 90-120 Ma) zircons, with a secondary population of Paleogene (40-60 Ma) zircons. Except for a single sample (sandstone from the Tilin Formation; Wang et al., 2014), Paleocene to middle Eocene sandstones lack grains older than Late Cretaceous and are statistically distinct from younger sandstones on the MDS plot (Fig. 9). U-Pb zircon ages from a sandstone of the Pondaung Formation at the southernmost edge of 
the Chindwin Basin (Oo et al., 2015) corroborate the lack of older zircons in Paleocenemiddle Eocene sandstones but should be interpreted with caution because of the low amount of zircon ages $(n=54)$. Upper Eocene to lower Oligocene sandstones from the backarc basin (Robinson et al., 2014) are similarly exempt of older zircons, but are dominated by Paleogene grains.
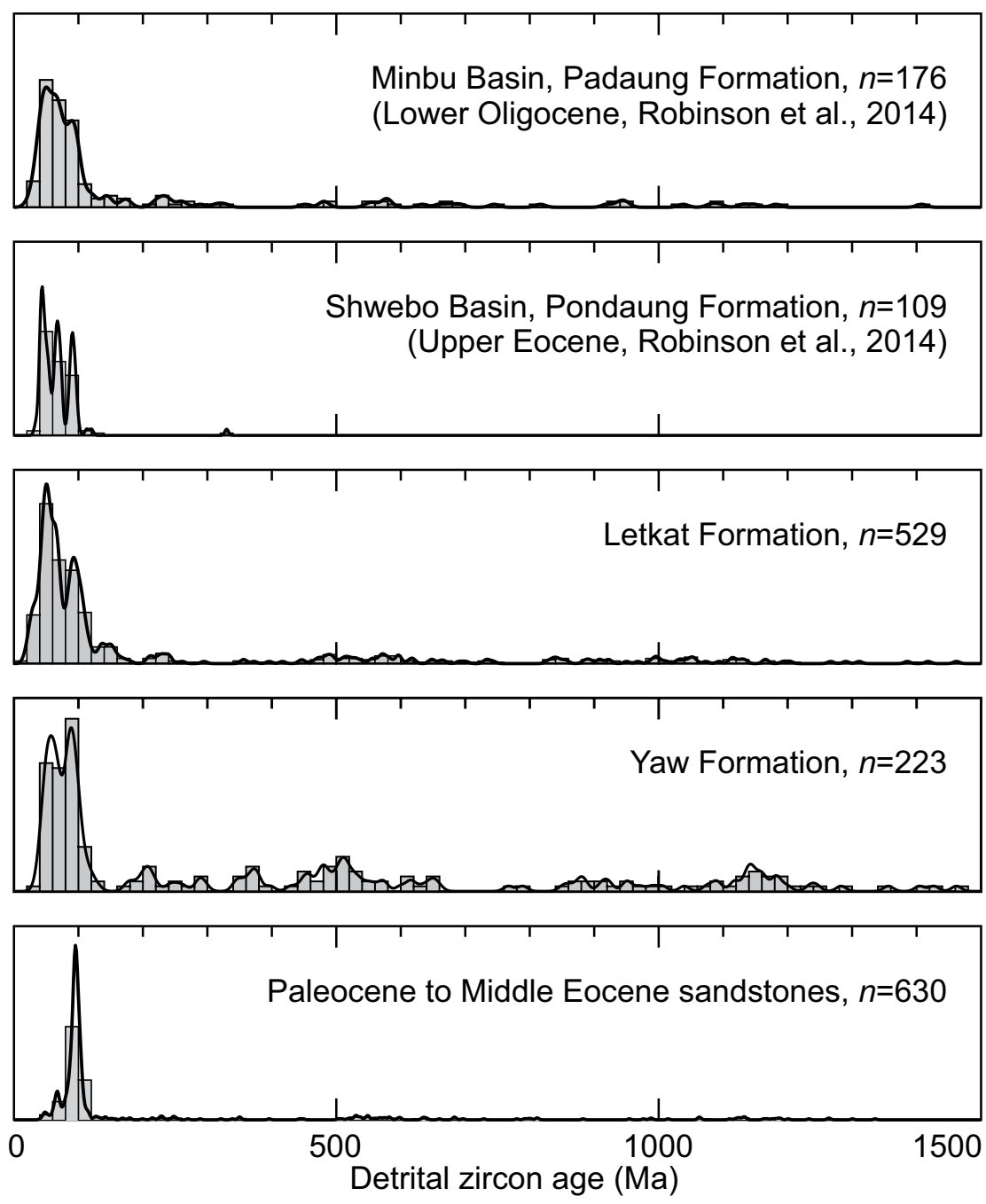

Figure 10. Kernel density estimators (KDE) and histograms (20 m.y. bins) for Paleocene to middle Eocene sandstones from the Chindwin Basin $(n=601$, combining two samples from the Paunggyi Formation, one sample from the Tilin Formation, and two samples from the Pondaung Formation, all from Wang et al., 2014, and one sample from the Paunggyi Formation from this study), from the Yaw Formation ( $n=202$, two samples from this study), and from the Letkat Formation ( $n=470$, combining four samples from this study and one from Wang et al., 2014), compared to upper Eocene sandstones from the Shwebo (backarc) Basin ( $n=109$, two samples from Robinson et al., 2014) and lower Oligocene sandstones from the Minbu Basin ( $n=176$, three samples from Robinson et al., 2014). The kernel density bandwidth of each plot was determined with the plug-in bandwidth selection method of Botev et al. (2010). 
Samples from the Yaw Formation yield a significant proportion of older zircons, with two notable peaks at 500 and $1200 \mathrm{Ma}$, as well as a prominent population of Paleogene zircons. This trend continues in the sandstones of the Letkat Formation, which display a dominant Paleogene peak and numerous Proterozoic zircons. Yaw and Letkat samples occupy the same space on the MDS plot. Samples from the lower Oligocene Padaung Formation (Robinson et al., 2014) in the nearby Minbu Basin display the same features. These features are also shared by Neogene samples from central Myanmar (Wang et al., 2014), as well as in most modern river samples draining the central Myanmar Basins (Garzanti et al., 2016).

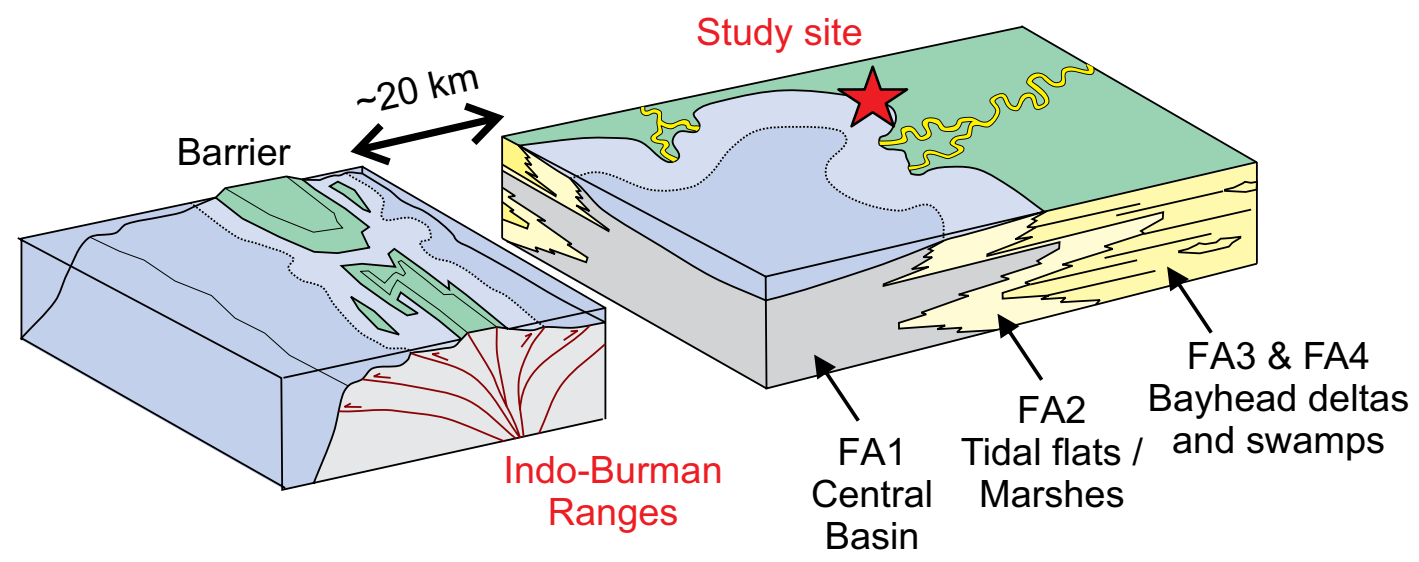

Figure 11. Depositional model for the Yaw Formation, inspired from the depositional model of tropical estuary of the Ouémé River in Benin (Anthony et al., 2002). Facies Association FA1 represents the central basin of a quasi-closed estuary; FA2 reflects the coastal/intertidal component; FA3 represents distributary channels of the bayhead delta; and FA4 deltaic swamps. We propose that the nascent Indo-Burman Ranges provided the necessary barrier to close the estuary.

\subsection{Age Model for the Yaw and Letkat Formations}

Youngest $\mathrm{U}-\mathrm{Pb}$ ages of detrital zircons from three samples and U-Pb ages of a sampled tuff are displayed on Figure 4. The maximum age of the Yaw Formation is constrained by a maximum depositional age of $39.0 \pm 0.8 \mathrm{Ma}(2 \sigma ; n=1$ zircon $)$ at the very most base of the formation $\sim 500 \mathrm{~m}$ below the composite log. Although ages based on a single zircon must be interpreted with caution, this age is in agreement with the age estimate for the unit just below, the Pondaung Formation, the upper member of which is dated at 40-39 Ma in the Minbu Basin via a combination of biostratigraphy, geochronology, and 
magnetostratigraphy (see review in Licht et al., 2015). The tuff is located at level $\sim 1000$ $\mathrm{m}$ in the formation, $\sim 180 \mathrm{~m}$ below the transition to the Letkat Formation, and yields a $38.3+0.7 /-0.9$ Ma $(2 \sigma ; n=13$ zircons $)$ volcanic age. This indicates an upper Bartonian age for the Yaw Formation and extremely fast sedimentation rates ( $>1 \mathrm{~m} / \mathrm{k} . \mathrm{y}$.$) .$ Assuming a similar accumulation rate, the last beds of the Yaw Formation occurred close to the Bartonian-Priabonian Boundary at 37.8 Ma (Gradstein et al., 2012).

Sandstones from the base of the Letkat Formation did not yield younger zircons, but a sample $\sim 350 \mathrm{~m}$ above the base of the formation yielded a maximum depositional age of $26.9+0.4 /-0.9 \mathrm{Ma}(2 \sigma ; \mathrm{n}=4$ zircons $)$. A second sample at the top of our section, $\sim 780 \mathrm{~m}$ below the top of the Letkat Formation yielded a single zircon at $20.2 \pm 0.5$ Ma $(2 \sigma)$; however, a more robust maximum depositional age of $23.5+0.3 /-0.4$ Ma $(2 \sigma ; n=3$ zircons) was calculated using more zircons. This suggests that the upper part of the Letkat Formation is upper Oligocene or possibly lower Miocene in age. Assuming that these maximum depositional ages are close to actual depositional ages due to the proximity of an active volcanic arc, the sedimentation rate of the Letkat Formation was much lower than for the Yaw Formation $(\sim 15 \mathrm{~cm} / \mathrm{k} . \mathrm{y}$.$) . This slow accumulation rate$ suggests that the base of the Letkat Formation would start, or be younger than, ca. $29 \mathrm{Ma}$ and that most of the lower Oligocene is missing in our section.

\section{DISCUSSION}

\subsection{Depositional Environments of the Paleogene Forearc}

The depositional environments of the Pondaung Formation in the Minbu Basin have previously been interpreted as reflecting a deltaic floodplain environment created by westward-prograding fluvial systems, where avulsive channels, crevasse belts with heterolithic deposits, and pedogenic floodplain fines laterally grade into each other (Licht et al., 2014b). Our observations in the Chindwin Basin are in line with this interpretation.

The combination and alternation of facies association FA1 to FA4 in the Yaw Formation is in many ways diagnostic of barrier-bound estuaries (Dalrymple et al., 1992). FA4 and FA3 are attributed to coastal swamps (paleo-histosols) and bayhead deltaic river distributaries, respectively. Sulfur content and isotopic composition indicate that whereas some of the swamps developed in a brackish setting, most were freshwater (Casagrande, 1987). FA2 reflects near-shore environments with several variations. Facies Sp and Cs can be interpreted as representing deltaic lobes and the delta front of 
bayhead deltas in the estuary bay (Anthony et al., 2002; Leeder, 2009). Facies Sw, with its evidence for wave-action, heterolithic stratifications with flaser, lenticular, and wavy bedding, indicates a tidal flat environment, which are commonly found along the shores of estuaries (Tessier et al., 1995).
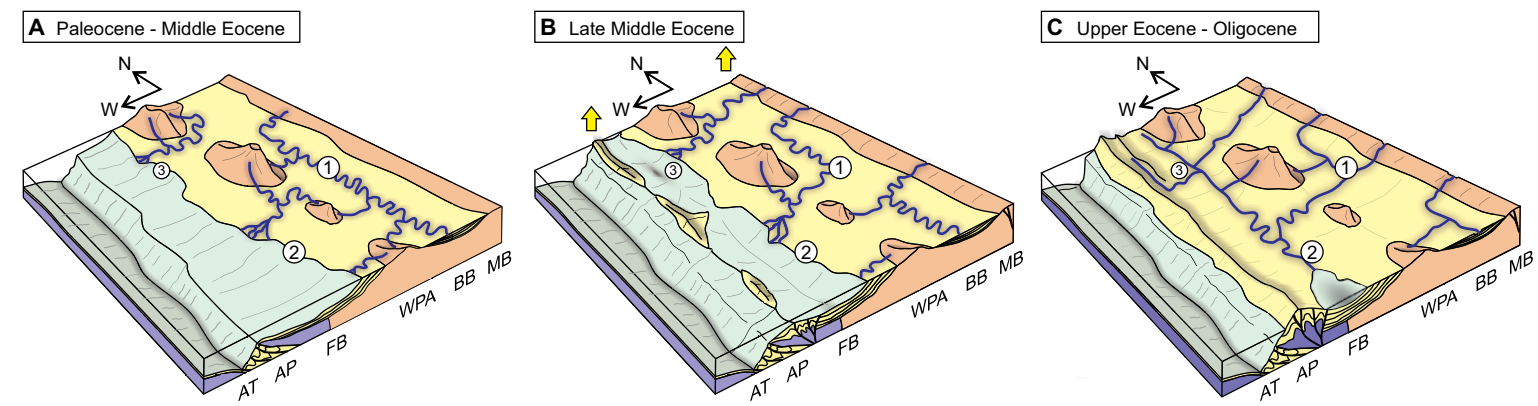

Figure 12. Evolution of the Burmese subduction margin and forearc basin from the Paleocene-middle Eocene (A), the late middle Eocene (B), and the upper Eocene-Oligocene (C). 1, 2, and 3 indicate the location of the Shwebo, Minbu, and Chindwin basins respectively (same as on Fig. 2). AT-Arakan Trench; AP-accretionary prism; FBforearc basin; WPA-Wuntho-Popa Arc; BB-backarc basin; MB-metamorphic belts.

This interpretation is corroborated by the presence of trace fossils Thalassinoides and Skolithos commonly found on firm grounds of tidal flats (Gingras et al., 2001). The prominent facies of this facies association, Ssm, contains evidence of wave-action and pedogenesis, but lacks well-marked tidal influence, and is interpreted here as reflecting either an intertidal marsh or a more vegetated shoreline (Allen, 2000). Finally, facies association FA1 reflects the sub-tidal central basin depositional environment of a barrier-bound estuary, where massive organic-rich mud is prominent (Anthony et al., 1996). The presence of marked anoxic conditions in the central basin, shown by the common occurrence of siderite beds (Mozley and Wersin, 1992), suggests poor mixing of deep water and a quasi-closed character for the estuary. Taken together, these facies associations closely resemble those of the tropical estuary of the Ouémé River in Benin, which is bounded by a large sand barrier created by longshore drift (Anthony et al., 2002). Interestingly, the relative rarity of facies $S w$, the notable absence of any marine fossils, the relative abundance of freshwater gastropods and unionids, and the overall low sulfur content in most of the coal suggests periods of intermittent estuary closure and shift to lacustrine setting, as is sometimes observed in barrier-bound estuaries (Roy et al., 1994). 


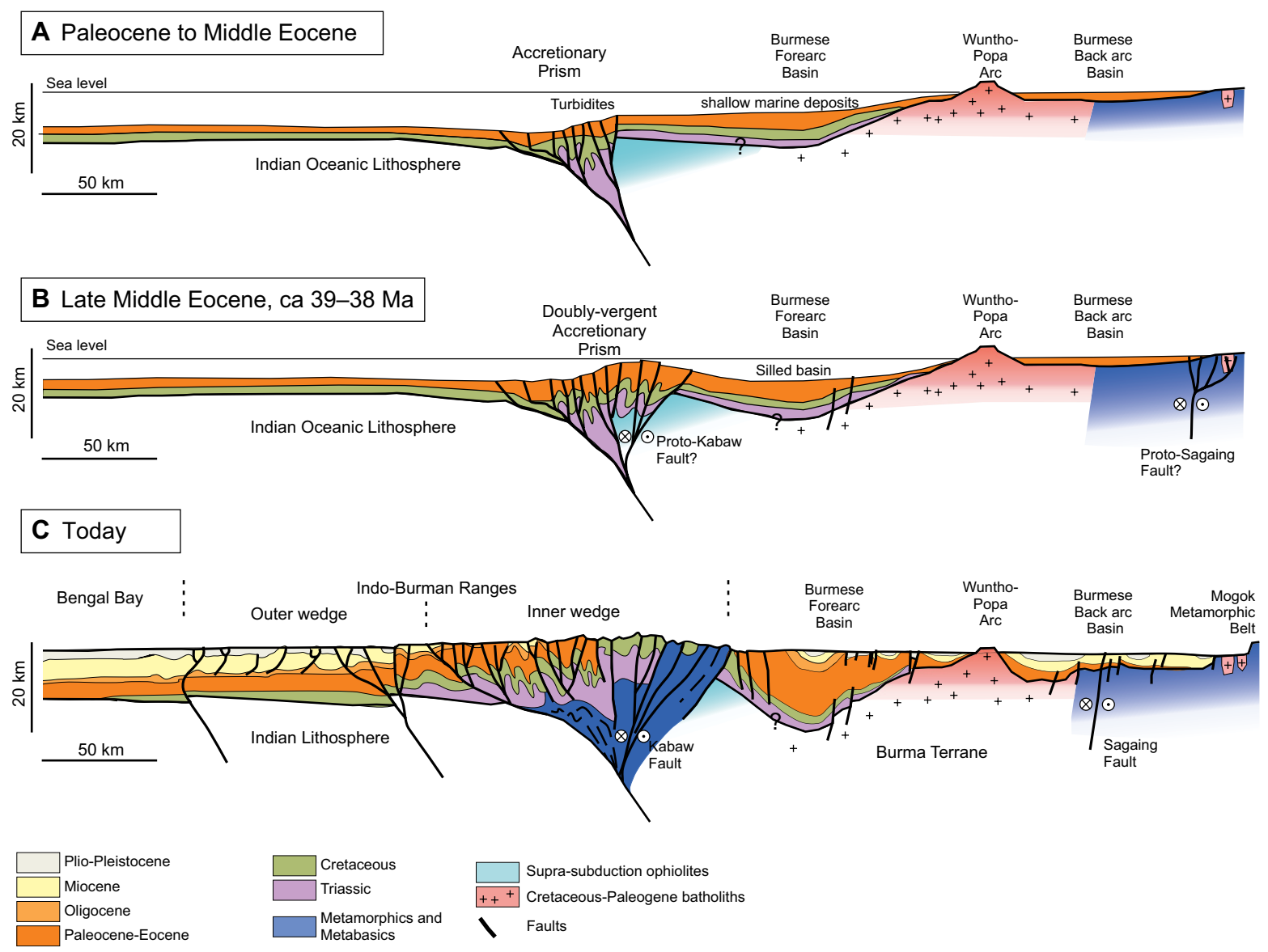

Figure 13. Schematic cross section across a $W$-E transect in western and central Myanmar (location on Fig. 2) during the Paleocene-middle Eocene (A), late middle Eocene (B), and today ( $C$; after Maurin and Rangin, 2009). The question mark indicates that the presence of Triassic rocks thrusted on the ophiolitic basement of the forearc is still unclear.

Thick, wide bodies made of cosets of facies St that lack any clear inclined heterolithic stratification and are capped by pedogenised, finer grained sets of facies Sm suggest fluvial channel bodies typical of braided river systems and associated overbank deposits (Leeder, 2009). The shift to pure fluviatile deposition and the presence of a depositional hiatus at the contact between the Yaw and Letkat Formations indicate that by the end of the Yaw Formation and for most of the Oligocene, the Chindwin Basin was overfilled. Moreover, paleocurrent flow measurements from the Letkat Formation indicate a shift in drainage orientation from westward-oriented in the Eocene to southwestwardoriented in the Oligocene.

\subsection{Tectonic Implications for the Evolution of the Accretionary Prism}

Extremely high accumulation rates ( $>1 \mathrm{~km} / \mathrm{m}$.y.) imply similar rates of basin subsidence to keep the bathymetry close to the tidal/shallow lacustrine domain, and indicate an 
active tectonic regime during the deposition of the Yaw Formation. To maintain the quasi-closed estuarine conditions over hundreds of meters of section, a permanent barrier is needed offshore to the west of our site in the area that is today occupied by the Indo-Burman Ranges. Wave-formed sandspits could have partly acted as a barrier, but the scale of the estuary ( $>100 \mathrm{~km}$ wide along the Burmese coast) is 5-10 times larger than modern wave-formed estuaries (Dalrymple et al., 1992).

Southward-directed flow measurements in the Letkat Formation indicate that by the late Oligocene, the Indo-Burman Ranges must have emerged on the western side of the Chindwin Basin in order to stop the westward progradation of fluvio-deltaic systems and instead drain fluvial systems southward. This corroborates preliminary work in the Minbu Basin farther south, where southward-prograding deltaic systems are observed starting in the early Oligocene (Gough and Hall, 2017). Incipient uplift of the accretionary prism must thus have started during or before the Oligocene. We propose that the quasi-closed estuarine conditions of the Yaw Formation in the Chindwin Basin reflect the initial emergence of the Indo-Burman Ranges offshore, which provided the necessary near-sea level topographic barrier (Fig. 11). This interpretation implies that by 39-38 Ma, the Indo-Burman Ranges were already being uplifted and were partly emerged. This timing is in agreement with geochronological data from Paleogene turbidites in the accretionary wedge farther south in the Indo-Burman Ranges, which yielded a persistent youngest zircon-fission track population at $37 \mathrm{Ma}$ (Allen et al. 2008), roughly coeval to the unconformity at the top of the Yaw Formation and the complete in-filling of the estuary. A major shift from westward-oriented drainage into the proto-Bengal Bay to southward-oriented drainage systems parallel to the subduction margin would have occurred after the complete emergence of the accretionary prism and the in-filling of the Chindwin basin estuary around ca. $37 \mathrm{Ma}$.

\subsection{Comparison with the Minbu Basin and Implications for the Onset of}

\section{Pull-Apart Subsidence}

There is a lack of sedimentological data regarding the Yaw Formation in the Minbu Basin, but the little we know contrasts with our observations in the Chindwin Basin. In the Minbu Basin, the Yaw Formation consists of gray shales with occasional limestone beds rich in shallow-marine trace fossils and fossil mollusks (Bender, 1983; Licht et al., 2013). Lignites and organic-rich black mudstones are absent. Additionally, the Minbu Basin lacks a depositional hiatus in the upper Eocene, and instead records continuous 
sedimentation into the lower Oligocene Padaung Formation (Nagappa, 1959). The Minbu Basin Yaw Formation is also much thinner (only $\sim 700 \mathrm{~m}$ thick at the western edge of the basin; United Nations, 1978). This indicates much lower accumulation rates $(<200 \mathrm{~m} / \mathrm{m} . \mathrm{y}$.) in the late Eocene and similarly slow rates of basin subsidence to keep the bathymetry close to shallow-marine conditions. Similar shallow-marine environments, accumulation rates and associated subsidence continued through the late Oligocene, with the deposition of the Shwezetaw, Padaung, and Okhmintaung Formations (United Nations, 1978).

During the late Paleogene, the Chindwin and Minbu Basins thus appear to have followed a significantly different subsidence history. Whereas subsidence was continuous in the Minbu Basin and bathymetry kept pace with moderate accumulation rates, subsidence was extremely high around 39-38 Ma in the Chindwin Basin and significantly slowed down at $37 \mathrm{Ma}$, leading to a stop of accumulation for most of the late Eocene and early Oligocene-resulting in the observed unconformity between the Yaw and Letkat Formations. These results indicate that by $39 \mathrm{Ma}$, the forearc was already partitioned into individual sub-basins with different histories. The high subsidence rates in the Chindwin Basin are in agreement with strike-slip deformation and pull-apart subsidence as the main mechanisms for forearc basin partitioning, as proposed by Rangin et al. (1999). The $\sim 22^{\circ} \mathrm{N}$ latitude topographic high, that today geomorphologically separates the two basins might have already been partly emerged or at least might have subsided more slowly, partly closing the Chindwin estuary to the south. Precise age constraints for the other Cenozoic units of the forearc basin - for a detailed backstripping analysisand basin-wide seismic lines are as of yet still lacking, preventing us from unequivocally confirming pull-apart subsidence as the main mechanism here; however, our interpretations suggest that the onset of basin pull-apart formation and strike-slip deformation of the basin margin dates back to at least $39 \mathrm{Ma}$, if not older.

\subsection{Provenance of the Paleogene Forearc Sediment and Implications for the Exhumation of the Metamorphic Belts}

Our grain-counts and $\mathrm{U}-\mathrm{Pb}$ ages distributions from Paleocene to middle Eocene sandstones indicate a provenance from Late Cretaceous-Paleogene rocks, likely the Wuntho-Popa magmatic arc located $\sim 100 \mathrm{~km}$ to the east, which was active during the same period and displays the same age peaks (Mitchell et al. 2012; Wang et al., 2014; Gardiner et al., 2015, 2017; Zhang et al., 2017b). Robinson et al. (2014) proposed a 
provenance from the Gangdese Arc in Tibet via a paleo-connection between Tibet and the Central Myanmar Basins using عHf fingerprinting of detrital zircons, but Zhang et al. (2017b) showed that zircons from the Wuntho-Popa Arc hold the exact $\varepsilon H f$ fingerprint as Gangdese batholiths. Additionally, a proximal source is corroborated in the Minbu Basin by $\mathrm{Nd}$ and $\mathrm{Sr}$ isotopic values, grain-counts, and paleocurrents that all indicate a nearby volcanic source located east of the forearc (Licht et al., 2013). Interestingly, the relatively high amount of quartz in samples from both Chindwin and Minbu basins suggests that part of the arc plutonic root might have already been exhumed in the late middle Eocene, corroborating a possible early uplift of the volcanic arc (Zhang et al., 2017b). Paleocene to middle Eocene samples from the Chindwin Basin contain slightly more volcanic lithic grains compared to coeval samples from the Minbu Basin (Fig. 8), indicating small lateral changes in the lithology of the exposed rocks along the Burmese subduction margin. The higher amount of sedimentary lithics in the Minbu Basin could reflect the recycling of older sedimentary rocks upstream, or ephemeral connections to the backarc basin and areas farther east, as one sample from the Tilin Formation seems to suggest (Fig. 9).

Sandstones from the Yaw Formation are marked by an increase of petrographic maturity and a significant amount of older (>150 Ma) zircons, which are almost absent in older sandstones. This trend is even more pronounced in sandstones of the Letkat Formation and indicates an increased contribution from older, quartz-rich basement rocks. In central Myanmar, basement rocks crop out in only a few areas: (1) to the east of the backarc basins along the Mogok, Slate, and Gaolingong metamorphic belts, where Paleozoic plutons and older metamorphics are prevalent; (2) occasionally farther east on the Shan Plateau, where Paleozoic and upper Mesozoic clastics crop out; and (3) to the west of the forearc in the metamorphosed core of the inner wedge of the accretionary prism, where small pockets of Triassic metamorphics crop out (Fig. 2; Licht et al., 2016). Our paleocurrent measurements in the Yaw Formation rule out the accretionary prism as a potential source; rather, our results indicate an increased contribution from the metamorphic belts and the Shan Plateau to the east. The absence of carbonate clasts-the dominant lithology on the Shan Plateau-suggests that the metamorphic belts are the primary contributor.

Similar age distributions are found in lower Oligocene samples from the Minbu Basin (Fig. 10; Robinson et al., 2014), suggesting a similar provenance. Following the onset of 
southward drainage systems ca. $37 \mathrm{Ma}$, a portion of the lower Oligocene material reaching the Minbu Basin might have transited via the Chindwin Basin. We unfortunately do not have any U-Pb data from the Yaw Formation in the Minbu Basin to test if the shift to a more mature source is older or coeval to the provenance change at ca. 39-38 Ma observed in the Chindwin Basin. However, Nd isotopes, Sr isotopes, and grain-counts on sandstones in the Minbu Basin corroborate an increased contribution of the metamorphic belts in the sedimentary supply starting in the late Eocene (Licht et al., 2016).

There are unfortunately few geochronological and petrographic data from the backarc basin to compare our results with. Two upper Eocene samples from the backarc basin contain only Cretaceous-Eocene zircons (Robinson et al., 2014), unlike what we see in Yaw and Letkat Formation sandstones. Although any interpretation based on only two, low $n(<60)$ samples is premature, we suspect that these samples might reflect local tributaries flowing down the Wuntho-Popa volcanic arc that do not reflect any contribution from the metamorphic belts that would have supplied older ( $>150 \mathrm{Ma}$ ) grains.

Our results thus show that by 39-38 Ma the Chindwin Basin had started receiving a regular supply of sediment from the metamorphic belts to the east. Interestingly, this age is roughly coeval with the $37.4 \pm 1.3 \mathrm{Ma}(2 \sigma)$ onset of gneiss formation and proposed onset for high-grade metamorphism (Searle et al., 2007), as well as the $36.2 \pm$ 1.6 Ma $(2 \sigma)$ age for the oldest $40 \mathrm{~K}-40 \mathrm{Ar}$ exhumation age along the metamorphic belts (Bertrand et al., 2001), showing the existence of a paleo-"Shan Scarp fault" system in the backarc areas predating the modern Sagaing Fault system. Our results thus confirm that the onset of high-grade metamorphism during the late middle Eocene is associated with an early exhumation episode of the metamorphic belts, which started providing sediment to the forearc basin. Ephemeral exhumation events might have started earlier in the middle Eocene, as suggested by one sample from the middle Eocene Tilin Formation (Fig. 9) and two middle Eocene overgrowth ages in zircons of the Mogok Metamorphic Belt (Barley et al., 2003).

\subsection{Evolution of the Burmese Subduction Margin during the Paleogene and Mechanisms of Uplift for the Indo-Burman Ranges}

We propose a three-step scenario for the evolution of the Burmese margin during the Paleogene (Figs. 12 and 13). 
(1) From the Paleocene to the middle Eocene, the Burmese subduction margin displays the regular morphology of Andean-type margins, with a nascent, underwater accretionary prism, and a forearc basin open to the trench occupied by westwardprograding deltaic systems fed by the denudation of the volcanic arc (Figs. 12A and $13 \mathrm{~A})$.

(2) In the late Bartonian-earliest Priabonian, around 39-38 Ma, the accretionary prism starts to emerge (Figs. 12B and 13B). The forearc basin is partitioned into two basins with varying subsidence rates likely due to pull-apart subsidence; the Minbu Basin in the south remains open to the proto-Bengal Bay to the west and the south, while in the north, quasi-closed estuarine conditions develop in the Chindwin Basin. Simultaneously, the metamorphic belts located to the east are progressively exhumed and start to feed the forearc.

(3) By $37 \mathrm{Ma}$, the Paleogene accretionary prism, that today forms the inner wedge of Indo-Burman Ranges, is completely emerged. The Chindwin Basin is temporarily overfilled and drainages in central Myanmar become southward directed (Fig. 12C). The modern geomorphology of central Myanmar is set up, with the central Myanmar low plains enclosed on the west and the east by topographic highs (Fig. 13C).

The 39-38 Ma window thus appears to be a period of significant change for the subduction margin, with the emergence of the inner wedge of the Indo-Burman Ranges, the first evidence of exhumation of the metamorphic belts, and the first indication of pull-apart partitioning of the forearc basin. Exhumation of the metamorphic belts could have sporadically started earlier in the middle Eocene, as discussed earlier, but the metamorphic belts became a prominent, continuous sediment supplier starting at 39-38 Ma. Similarly, pull-apart subsidence of the basin might have started earlier, but the forearc appears to be significantly partitioned during this time window.

Earlier onset of uplift and exhumation of the accretionary prism is also probable, as proposed by previous authors (as early as the Cretaceous; Socquet et al., 2002; Zhang et al., 2017a). However, the inner wedge lacks shallow-marine deposits and is dominated by marine turbidite sequences (Bender, 1983), indicating that depositional environments shifted very quickly from deep-sea deposition in the trench to sub-aerial deposition. It is thus likely that most of the uplift started only slightly before 39-38 Ma. Contacts between sedimentary units exposed in the inner wedge provide a few more details about what happened after this early uplift of the accretionary prism. On the 
eastern side of the inner wedge of the accretionary prism, Eocene marine rocks are unconformably overlain by a conglomeratic molasse, the Maw Gravels, which yield late middle Miocene fossil mammals (Bender, 1983). In places, a 10-m-thick, ferralitic paleosol profile with a $0.5-1-\mathrm{m}$-thick petroplinthic horizon made of continuous, thick iron crust developed in the Eocene rocks at the contact between both units (Fig. DR3 [see footnote 1]; Licht, 2013). The thickness of the lateritic profile and the presence of a petroplinthic horizon indicate that the development of the paleosol likely took a significant amount of time-up to several million years (Valeton, 1994). This finding indicates that there was a long period of tectonic quiescence between the initial uplift of the inner wedge during the late Eocene and the deposition of the late middle Miocene Molasse. The deposition of the Maw Gravels was likely related to the onset of the recent, Mio-Pliocene uplift of the Indo-Burman Ranges that exposed the outer wedge of the accretionary prism (Maurin and Rangin, 2009). The uplift of the Indo-Burman Ranges thus appears to have occurred in at least two steps: first, during the late Eocene when the inner wedge was exposed, and second, during the late Miocene-Pliocene when the outer wedge was formed.

Various mechanisms are proposed to explain the late Miocene-Pliocene uplift of the Indo-Burman Ranges, including the subduction of the large amount of Neogene sediments that fill up the Bengal Basin and the Sylhet Basin (Maurin and Rangin, 2009), and increased E-W shortening of the Burmese platelet due to the arrival of mid-crustal flow from the east following the late Miocene collapse of the Tibetan Plateau (Rangin et al., 2013). However, these mechanisms are only valid for the Neogene and cannot explain the late middle Eocene uplift of the inner wedge.

A temporary shift to flat slab subduction could explain the uplift of the accretionary prism, but would not explain the extremely high subsidence rates in the foreland basin or the high-grade metamorphism throughout the backarc areas (Finzel et al., 2011). The accretion of a small allochthonous terrane or volcanic arc, as proposed by others (i.e., Acharyya, 2007, 2015), could partly explain the uplift, but would also fail to explain the coeval shift to intense strike-slip deformation and subsidence in the forearc; there is also no clear evidence for such allochthonous blocks in the accretionary prism. A change of plate kinematics driving increased E-W convergence and upper plate shortening could also explain the shift to a more compressive regime and the resulting uplift of the accretionary prism; however, in the Paleogene, the convergence of the Indian plate 
relative to Southeast Asia trended to lower velocities and increased obliquity, which would not favor this hypothesis (Lee and Lawver, 1995; Cande et al., 2010; van Hinsbergen et al., 2011b). Still others have proposed a collision of a northeast moving Indian plate with the Burmese margin slightly before 39-38 Ma followed by a change of convergence direction from NE to N (Morley, 2002; Aitchison et al., 2007; Vérard et al., 2017). The collision could have anchored the Burmese platelet to India and dragged it northward as the direction of convergence changed, providing an explanation for an episode of shortening in the accretionary prism followed by strike-slip deformation of the upper plate. However, it is remarkable that such a collision between a cold, thick continental plate and the weak, hot Burmese margin (Morley, 2009) did not result in more surface deformation and uplift; moreover, strike-slip deformation (and related pull-apart subsidence) seems coeval rather than posterior to accretionary wedge uplift. Today, the obliquity ratio (ratio of the strike-slip velocity divided by the sum of strikeslip and normal velocity) of the convergence along the Burmese subduction margin is $\sim 0.65$ and so can be called "hyper-oblique" (Nielsen et al., 2004). The core of the inner wedge of the Indo-Burman Ranges displays a positive flower structure and is traversed by the Kabaw strike-slip Fault, which accommodates $1 / 4-1 / 3$ of the N-S strike slip deformation of the Burma Terrane (Nielsen et al., 2004; Socquet et al., 2006; Maurin and Rangin, 2009). In this sense, the inner wedge of the Indo-Burman Ranges is very similar to retro-wedges formed along hyper-oblique convergence zones where the obliquity ratio $\mathrm{r}$ is $>0.5$ (Burbidge and Braun, 1998; McClay et al., 2004). The Eocene uplift of the inner (retro-) wedge of the Indo-Burman Ranges can be explained in light of the known evolution of accretionary prisms formed by hyper-oblique convergence. Such systems go through a period of fast retro-wedge building and uplift via the transition from localized strain partitioning in the accretionary wedge to full strain partitioning, and all strike slip motion is eventually accommodated by one or several individual fault systems (McClay et al., 2004; Leever et al., 2011). Evidence of coeval pull-apart subsidence and partitioning in the forearc and of the onset of high-grade metamorphism associated with exhumation of the metamorphic belts corroborates intense shear and strike-slip faulting on the Burma platelet during that time. Thus, we interpret the late middle Eocene uplift of the Indo-Burman Ranges as reflecting localized strain partitioning and wedge buildup prefiguring the onset of a paleo-Kabaw Fault system ("oblique wedge stage" of Leever et al., 2011). The onset of full strain partitioning and of the paleo-Kabaw Fault 
system would have been coeval or have shortly followed the late middle Eocene, eventually slowing the uplift of the accretionary wedge.

\subsection{Implications for the History of India Asia Convergence}

Our interpretations imply that the convergence of the Indian plate along the Burmese margin has been hyper-oblique since at least the late Bartonian, ca. 39-38 Ma, and that it resulted in the coeval uplift of the inner wedge of the accretionary prism, pull-apart subsidence and partitioning of the forearc basins, and high-grade metamorphism and exhumation along the metamorphic belts (Fig. 13). While the modern Burmese sliver fault system is commonly dated to the middle Miocene and the opening of the Andaman Sea (Khan and Chakraborty 2005; Socquet et al., 2006), our results suggest that a similar paleo-sliver system, with a paleo-Kabaw Fault in the accretionary prism and a paleoShan Scarp Fault in the metamorphic belts, was already set up by the late middle Eocene or shortly thereafter (Fig. 13B). These observations corroborate evidence for ca. Eocene to ca. Miocene syn-kinematic deposition in the backarc basin, indicating that a proto"Shan Scarp" Fault was already active (Morley, 2017). Strike-slip deformation of the Burmese margin could have started even earlier, sometime in the middle Eocene, but would have been less substantial.

Our results thus suggest that the northward drag of the Burmese platelet pre-dates the opening of the Andaman Sea and the set-up of the modern sliver system in the middle Miocene by at least 20 million years. Central Myanmar has thus likely moved northward by much more than $400-500 \mathrm{~km}$, which is the lower-end estimate of northward motion achieved by simply closing the Andaman Sea rift system (Maung, 1987). We suspect that the actual motion of Central Myanmar over this time period to be closer to Mitchell's (1993) upper estimate of $\sim 1100 \mathrm{~km}$, with $600-700 \mathrm{~km}$ of the motion occurring between the late middle Eocene and the middle Miocene; this movement was accommodated to the opening of the Eocene-Miocene Mergui and North Sumatra Basins south the Andaman Rift (Hall and Morley, 2004).

There is no clear evidence for shortening and surface uplift in central Myanmar before the late middle Eocene. Leading up to the shift in sedimentation regime 39-38 Ma, accumulation in the forearc basin was continuous and dominated by the denudation of the volcanic arc from the Paleocene to the late middle Eocene, as is seen in standard Andean-type margins, and thus rules out a collision with India. A collision of the Indian Plate with the Burmese margin sometime during the early to middle Eocene, as is 
proposed by most of the kinematic models dominated by extrusion processes (Tapponnier et al., 1982; Replumaz and Tapponnier, 2003; Replumaz et al., 2010; Cogné et al., 2013), and more exotic scenarios (Aitchison et al., 2007; Vérard et al., 2017), seems thus unlikely. If such a collision had occurred, it would have been located in northernmost Myanmar, in the Eastern Himalayan Syntaxis-where forearc strata have not been preserved (Fig. 2), leaving most of the Burmese margin undeformed.

Our reconstruction of the history of the Burmese subduction margin validates geodynamic models that locate Myanmar east of the collision zone as early as the Paleocene, with Indochina already forming a narrow peninsula at the southeastward extremity of East Asia. This narrow peninsula must have had a similar-to-today N-S orientation since at least the late middle Eocene to explain hyper-oblique convergence along the Burmese margin. In this sense, our results are in agreement with models dominated by homogeneous thickening and continuous deformation of weaker Asian lithosphere that propose a conservative, similar-to-today pre-collisional paleogeography for SE Asia and argue that most of Myanmar and the Burma Terrane was not particularly shortened or thickened by the collision with India (Fig. 1C; e.g., England and Houseman, 1986; Molnar et al., 1993; Hallet and Molnar, 2001; Shen et al., 2001; van Hinsbergen et al., 2011a, 2012; Hall, 2012; Seton et al., 2012). However, our results do not completely exclude extrusion and rotation processes as active post-collisional processes in SE Asia; the shift to hyper-oblique convergence along the Burmese margin could be explained by an undetermined amount of post-collisional rotation of peninsular Indochina. Our reconstructions show that this rotation must have been achieved by 39-38 Ma to explain the onset of hyper-oblique convergence along the Burmese margin. The idealized extrusion-dominated reconstructions of van Hinsbergen et al. (2011a), adapted from Replumaz and Tapponnier (2003) and Royden et al. (2008) are the closest analogues to this scenario. Paleomagnetic estimates of post-collisional clockwise rotation in peninsular Indochina yield results of variable magnitude, with estimates of 20-30 for the whole of Indochina (Richter and Fuller, 1996; Charusiri et al., 2006; Li et al., 2017), and as much as $>70^{\circ}$ in some places (Sato et al., 2001; Tong et al., 2016). Yet, the lack of detailed geological data in peninsular Indochina (i.e., ages and origins of volcanism and metamorphism along shear zones) often precludes a robust age interpretation for this rotation, as evidenced by the recent synthesis of Li et al. (2017), and ultimately hinders a clear evaluation of the accuracy of this scenario. 
We also see three additional mechanisms to possibly explain the shift to hyper-oblique convergence in the late middle Eocene, which are more controversial.

(1) A potential collision between the eastern tip of India and northernmost Myanmar shortly before 39 Ma could have anchored the Burmese margin to the Indian plate's northwards motion. However, this timing is at odds with many other studies along the India-Asia Suture that indicate a collision started ca. 55 Ma (see reviews in Najman, 2006; Najman et al., 2010).

(2) A late and poorly dated small rotation $\left(\sim 15^{\circ}\right.$ counterclockwise $)$ of Indian convergence in the middle Eocene (Lee and Lawver, 1995; Cande et al., 2010) could have triggered the shift to strike-slip deformation. This late rotation would have slightly increased the convergence obliquity along the margin, but it seems too small to have alone triggered strain partitioning on the Burmese margin.

(3) A change in the properties of the subducting material may have favored the shift to strain partitioning on the Burmese margin. By the late Eocene, most of the old, Jurassic Tethyan oceanic crust had been subducted below the Asian subduction margin. The late Eocene would correspond roughly to the time when Cenozoic oceanic crust from the Indian Ocean reached the Burmese margin (Seton et al., 2012; Hall, 2012). This younger, less dense oceanic lithosphere could have acted as a giant sheet anchor increasing both the northward drag of the subduction margin and the shear on the Burmese plate.

Cretaceous-Paleogene paleomagnetic data from the Burmese platelet could potentially help us validate or reject these scenarios by reconstructing the amount and timing of paleo-rotation of the subduction margin; however, paleomagnetic data from central Myanmar are so far virtually nonexistent.

\section{CONCLUSIONS}

Our results show that the modern tectonic configuration of central Myanmar, today a sliver plate bounded to the west by the Indo-Burman Ranges and the Kabaw Fault, and to the east by the Burmese metamorphic belts and the Sagaing Fault, was actually first formed during a short time window in the late middle Eocene.

From the Paleocene to the middle Eocene, the Burmese margin displayed the regular morphology of an Andean-type margin, with a forearc basin developed on a nascent accretionary prism open to the trench, where westward-prograding deltaic systems were fed by the denudation of the Wuntho-Popa volcanic arc. In the late middle Eocene, around 39-38 Ma, the accretionary prism started emerging. Pull-apart subsidence 
partitioned the forearc basin into two basins - the Chindwin Basin to the north and the Minbu Basin to the south. Quasi-closed estuarine conditions developed in the Chindwin Basin, whereas the Minbu Basin remained more open to the ocean. Simultaneously, increased shear stress in the backarc area led to metamorphism and exhumation of the Burma terrane basement. By $37 \mathrm{Ma}$, the Paleogene accretionary prism, forming today the inner wedge of Indo-Burman Ranges, had completely emerged. The main drainages in central Myanmar became southward directed, and the modern central Myanmar low plains were formed.

This tectonic evolution can be explained in light of the known evolution of accretionary prisms formed by hyper-oblique convergence. Coeval pull-apart subsidence and partitioning in the forearc, and onset of high-grade metamorphism associated with exhumation in the metamorphic belts indicate both intense shear and strike-slip faulting on the Burmese platelet during that time, and high obliquity of the convergence at the Burmese margin. We interpret the synchronous uplift of the Indo-Burman Ranges as reflecting accretionary wedge build-up marking the onset of a paleo-Kabaw Fault system. These interpretations imply that a similar-to-today sliver system, with a paleoKabaw Fault in the accretionary prism and a paleo-Sagaing shear zone (the paleo-Shan Scarp Fault) creating high-grade metamorphism in the metamorphic belts to the east, was already set up by the late middle Eocene. This evolution indicates that the Burmese sliver platelet is at least twice older than previously thought and that it has experienced a significant ( $>500 \mathrm{~km}$ ), but yet to be determined, amount of northward motion. Finally, our results do not support any India-Asia convergence scenario involving a Paleogene collision of India with the Burmese subduction margin. Our reconstruction for the evolution of the Burmese margin is more in agreement with conservative geodynamic models for the India-Asia convergence arguing for a close-to-modern pre-collisional paleogeometry for the Indochina Peninsula, and indicates that any post-collisional rotation of Indochina, if it existed, must have been achieved by 39 Ma.

\section{ACKNOWLEDGMENTS}

This research was primarily funded by the European Research Council Consolidator Grant MAGIC 649081, the Marie Curie fellowship ECAMMETT 656731, and the University of Washington. We thank two anonymous reviewers, Chris Morley, Kyi Kyi Thein, Chit Sein, J.-J. Jaeger, O. Chavasseau, V. Lazarri, Andrew Schauer, D. Cowan, D. van 
Hinsbergen, M. Mueller, M. Needle, M. Koehler, A. Gagnon, M. Pecha, G. Gehrels, D. Giesler, A. Pullen, B. Nelson, and F. Teng for prolific discussions, and assistance in the field and in the lab.

1GSA Data Repository item 2018336, including supplementary figures, geochronological data, sulfur isotope and grain counting results, is available at http://www.geosociety.org/datarepository/2018 or by request to editing@geosociety.org.

\section{References}

Acharyya, S.K., 2007, Collisional emplacement history of the Naga-Andaman ophiolites and the position of the eastern Indian suture: Journal of Asian Earth Sciences , v. 29, no. 2, 2 p. 29-242, https://doiorg.insu.bib.cnrs.fr/10.1016/j.jseaes.2006.03.003.

Acharyya, S.K., 2015, Indo-Burma Range: a belt of accreted microcontinents, ophiolites and Mesozoic-Paleogene flyschoid sediments: International Journal of Earth Sciences , v. 104, no. 5, p. 1235-1251, https://doiorg.insu.bib.cnrs.fr/10.1007/s00531-015-1154-6.

Adnet, S., Cappetta, H., Beard, K.C., Marivaux, L., Marandat, B., Chaimanee, Y., et al, 2008, First myliobatiform teeth (Elasmobranchii, Neoselachii) from the pondaung formation (late middle Eocene) of central Myanmar: Neues Jahrbuch für Geologie und Palaontologie, Abhandlungen, v. 247, no. 3, p. 335-340, https://doiorg.insu.bib.cnrs.fr/10.1127/0077-7749/2008/0247-0335.

Aitchison, J.C., Ali, J.R., and Davis, A.M., 2007, When and where did India and Asia collide?: Journal of Geophysical Research. Solid Earth , v. 112, B5, https://doiorg.insu.bib.cnrs.fr/10.1029/2006JB004706.

Allègre, C.O., Courtillot, V., Tapponnier, P., Hirn, A., Mattauer, M., Coulon, C., et al, 1984, Structure and evolution of the Himalaya-Tibet orogenic belt: Nature , v. 307, no. 5946, p. 17-22, https://doi-org.insu.bib.cnrs.fr/10.1038/307017a0.

Allen, J.R., 2000, Morphodynamics of Holocene salt marshes: A review sketch from the Atlantic and Southern North Sea coasts of Europe: Quaternary Science Reviews , v. 19, no. 12, p. 1155-1231, https://doi-org.insu.bib.cnrs.fr/10.1016/S02773791(99)00034-7.

Allen, R., Najman, Y., Carter, A., Barfod, D., Bickle, M.J., Chapman, H.J., et al, 2008, Provenance of the Tertiary sedimentary rocks of the Indo-Burman Ranges, Burma (Myanmar): Burman arc or Himalayan-derived?: Journal of the Geological Society , v. 165 , no. 6, p. 1045-1057, https://doi-org.insu.bib.cnrs.fr/10.1144/001676492007-143.

Anthony, E.J., Lang, J., and Oyédé, L.M., 1996, Sedimentation in a tropical, microtidal, wave-dominated coastal-plain estuary: Sedimentology , v. 43, no. 4, p. 665-675, https://doi-org.insu.bib.cnrs.fr/10.1111/j.1365-3091.1996.tb02019.x. 
Anthony, E.J., Oyédé, L.M., and Lang, J., 2002, Sedimentation in a fluvially infilling, barrier-bound estuary on a wave-dominated, microtidal coast: The Ouémé River estuary, Benin, West Africa: Sedimentology, v. 49, no. 5, p. 1095-1112, https://doi-org.insu.bib.cnrs.fr/10.1046/j.1365-3091.2002.00491.x.

Bannert, D., Lyen, A.S., and Htay, T., 2011, The Geology of the Indoburman Ranges in Myanmar: Geologisches Jahrbuch , v. 101, p. 5-101.

Barley, M.E., Pickard, A.L., Zaw, K., Rak, P., and Doyle, M.G., 2003, Jurassic to Miocene magmatism and metamorphism in the Mogok metamorphic belt and the IndiaEurasia collision in Myanmar: Tectonics , v. 22, no. 3, https://doiorg.insu.bib.cnrs.fr/10.1029/2002TC001398.

Bender, F., 1983, Geology of Burma: Berlin, Gebrüder Borntraeger, 293 p.

Bertrand, G., and Rangin, C., 2003, Tectonics of the western margin of the Shan plateau (central Myanmar): Implication for the India-Indochina oblique convergence since the Oligocene: Journal of Asian Earth Sciences , v. 21, no. 10, p. 1139-1157, https://doi-org.insu.bib.cnrs.fr/10.1016/S1367-9120(02)00183-9.

Bertrand, G., Rangin, C., Maluski, H., Bellon, H., and Party, G.S., 2001, Diachronous cooling along the Mogok Metamorphic Belt (Shan scarp, Myanmar): The trace of the northward migration of the Indian syntaxis: Journal of Asian Earth Sciences , v. 19, no. 5 , p. 649-659, https://doi-org.insu.bib.cnrs.fr/10.1016/S13679120(00)00061-4.

Botev, Z.I., Grotowski, J.F., and Kroese, D.P., 2010, Kernel density estimation via diffusion: Annals of Statistics , v. 38, no. 5, p. 2916-2957, https://doiorg.insu.bib.cnrs.fr/10.1214/10-AOS799.

Brunnschweiler, R.O., 1966, On the Geology of the Indoburman Ranges: Journal of the Geological Society of Australia , v. 13, p. 137-194, https://doiorg.insu.bib.cnrs.fr/10.1080/00167616608728608.

Burbidge, D.R., and Braun, J., 1998, Analogue models of obliquely convergent continental plate boundaries: Journal of Geophysical Research. Solid Earth , v. 103, B7, p. 15,221-15,237, https://doi-org.insu.bib.cnrs.fr/10.1029/98JB00751.

Cande, S.C., Patriat, P., and Dyment, J., 2010, Motion between the Indian, Antarctic and African plates in the early Cenozoic: Geophysical Journal International , v. 183, no. 1, p. 127-149, https://doi-org.insu.bib.cnrs.fr/10.1111/j.1365246X.2010.04737.x.

Casagrande, D.J., 1987, Sulphur in peat and coal, in Scott, A.C., ed., Coal and coal-bearing strata: Recent advances : Geological Society of London Special Publication 32, p. 87-105, https://doi-org.insu.bib.cnrs.fr/10.1144/GSL.SP.1987.032.01.07.

Chaimanee, Y., Chavasseau, O., Beard, K.C., Kyaw, A.A., Soe, A.N., Sein, C., et al, 2012, Late Middle Eocene primate from Myanmar and the initial anthropoid colonization of Africa: Proceedings of the National Academy of Sciences of the United States of America , v. 109, p. 10,293-10,297, https://doiorg.insu.bib.cnrs.fr/10.1073/pnas.1200644109.

Charusiri, P., Imsamut, S., Zhuang, Z., Ampaiwan, T., and Xu, X., 2006, Paleomagnetism of the earliest Cretaceous to early late Cretaceous sandstones, Khorat Group, 
Northeast Thailand: Implications for tectonic plate movement of the Indochina block: Gondwana Research , v. 9, no. 3, p. 310-325, https://doiorg.insu.bib.cnrs.fr/10.1016/j.gr.2005.11.006.

Chavasseau, O., Chaimanee, Y., Coster, P., Emonet, E.G., Soe, A.N., Kyaw, A.A., Maung, A., Rugbumrung, M., Shwe, H., and Jaeger, J.-J., 2010, First record of a chalicothere from the Miocene of Myanmar: Acta Palaeontologica Polonica, v. 55, p. 13-22, https://doi-org.insu.bib.cnrs.fr/10.4202/app.2009.0033.

Chavasseau, O., Chaimanee, Y., Tun, S.T., Soe, A.N., Barry, J.C., Marandat, B., et al, 2006, Chaungtha, a new Middle Miocene mammal locality from the Irrawaddy Formation, Myanmar: Journal of Asian Earth Sciences, v. 28, no. 4, p. 354-362, https://doi-org.insu.bib.cnrs.fr/10.1016/j.jseaes.2005.10.012.

Chen, Y., Courtillot, V., Cogné, J.P., Besse, J., Yang, Z., and Enkin, R., 1993, The configuration of Asia prior to the collision of India: Cretaceous paleomagnetic constraints: Journal of Geophysical Research, Solid Earth , v. 98, B12, p. 21,92721,941 .

Chew, D.M., Petrus, J.A., and Kamber, B.S., 2014, U-Pb LA-ICPMS dating using accessory mineral standards with variable common Pb: Chemical Geology , v. 363, p. 185199, https://doi-org.insu.bib.cnrs.fr/10.1016/j.chemgeo.2013.11.006.

Cogné, J.P., Besse, J., Chen, Y., and Hankard, F., 2013, A new Late Cretaceous to Present APWP for Asia and its implications for paleomagnetic shallow inclinations in Central Asia and Cenozoic Eurasian plate deformation: Geophysical Journal International , v. 192, no. 3, p. 1000-1024, https://doiorg.insu.bib.cnrs.fr/10.1093/gji/ggs104.

Collinson, J.D., Mountney, N.P., and Thompson, D.B., 2006, Sedimentary Structures: Terra Publishing, third edition, $292 \mathrm{p}$.

Dalrymple, R.W., Zaitlin, B.A., and Boyd, R., 1992, Estuarine facies models: conceptual basis and stratigraphic implications: perspective: Journal of Sedimentary Research , v. 62, no. 6, https://doi-org.insu.bib.cnrs.fr/10.1306/D4267A69-2B26-11D78648000102C1865D.

DeCelles, P.G., Kapp, P., Gehrels, G.E., and Ding, L., 2014, Paleocene-Eocene foreland basin evolution in the Himalaya of southern Tibet and Nepal: Implications for the age of initial India-Asia collision: Tectonics , v. 33, no. 5, p. 824-849, https://doiorg.insu.bib.cnrs.fr/10.1002/2014TC003522.

DeCelles, P.G., Robinson, D.M., and Zandt, G., 2002, Implications of shortening in the Himalayan fold-thrust belt for uplift of the Tibetan Plateau: Tectonics , v. 21, no. 6, https://doi-org.insu.bib.cnrs.fr/10.1029/2001TC001322.

Dickinson, W.R., 1985, Interpreting provenance relations from detrital modes of sandstones, in Zuma, G.G., ed., Provenance of Arenites: Cosenza, Italy , D. Reidel Publishing Company, p. 333-361, https://doi-org.insu.bib.cnrs.fr/10.1007/97894-017-2809-6_15.

England, P., and Houseman, G., 1986, Finite strain calculations of continental deformation: 2. Comparison with the India-Asia collision zone: Journal of 
Geophysical Research, Solid Earth , v. 91, B3, p. 3664-3676, https://doiorg.insu.bib.cnrs.fr/10.1029/JB091iB03p03664.

Finzel, E.S., Trop, J.M., Ridgway, K.D., and Enkelmann, E., 2011, Upper plate proxies for flat-slab subduction processes in southern Alaska: Earth and Planetary Science Letters , v. 303, no. 3-4, p. 348-360, https://doiorg.insu.bib.cnrs.fr/10.1016/j.epsl.2011.01.014.

Fry, B., Silva, S.R., Kendall, C., and Anderson, R.K., 2002, Oxygen isotope corrections for online $\delta 34 S$ analysis: Rapid Communications in Mass Spectrometry , v. 16, no. 9, p. 854-858, https://doi-org.insu.bib.cnrs.fr/10.1002/rcm.651.

Gardiner, N.J., Hawkesworth, C.J., Robb, L.J., Whitehouse, M.J., Roberts, N.M., Kirkland, C.L., and Evans, N.J., 2017, Contrasting Granite Metallogeny through the Zircon Record: A Case Study from Myanmar: Scientific Reports , v. 7, no. 1, p. 748, https://doi-org.insu.bib.cnrs.fr/10.1038/s41598-017-00832-2.

Gardiner, N.J., Searle, M.P., Robb, L.J., and Morley, C.K., 2015, Neo-Tethyan magmatism and metallogeny in Myanmar-An Andean analogue?: Journal of Asian Earth Sciences , v. 106, p. 197-215, https://doiorg.insu.bib.cnrs.fr/10.1016/j.jseaes.2015.03.015.

Garzanti, E., Wang, J.G., Vezzoli, G., and Limonta, M., 2016, Tracing provenance and sediment fluxes in the Irrawaddy River basin (Myanmar): Chemical Geology, v. 440, p. 73-90, https://doi-org.insu.bib.cnrs.fr/10.1016/j.chemgeo.2016.06.010.

Gibbons, A.D., Zahirovic, S., Müller, R.D., Whittaker, J.M., and Yatheesh, V., 2015, A tectonic model reconciling evidence for the collisions between India, Eurasia and intra-oceanic arcs of the central-eastern Tethys: Gondwana Research , v. 28, no. 2, p. 451-492, https://doi-org.insu.bib.cnrs.fr/10.1016/j.gr.2015.01.001.

Gingras, M.K., Pemberton, S.G., and Saunders, T., 2001, Bathymetry, sediment texture, and substrate cohesiveness; their impact on modern Glossifungites trace assemblages at Willapa Bay, Washington: Palaeogeography, Palaeoclimatology, Palaeoecology , v. 169, no. 1-2, p. 1-21, https://doiorg.insu.bib.cnrs.fr/10.1016/S0031-0182(01)00212-7.

Gough, A., and Hall, R., 2017, Oligocene Fluvio-Deltaic Depositional Environments Salin Sub-Basin, Central Myanmar [abs.]: American Geophysical Union Fall Meeting 2017, New Orleans, abstract \#EP21F-1904.

Gradstein, F.M., Ogg, J.G., Schmitz, M., and Ogg, G., eds., 2012, The Geologic Time Scale 2012 : Elsevier, 1176 p.

Hall, R., 2012, Late Jurassic-Cenozoic reconstructions of the Indonesian region and the Indian Ocean: Tectonophysics , v. 570, p. 1-41, https://doiorg.insu.bib.cnrs.fr/10.1016/j.tecto.2012.04.021.

Hall, R., and Morley, C.K., 2004, Sundaland basins, in Clift, P., et al, eds., Continent-Ocean Interactions within the East Asian Marginal Seas: Washington, D.C. , American Geophysical Union, Geophysical Monograph, v. 149, p. 55-85.

Hallet, B., and Molnar, P., 2001, Distorted drainage basins as markers of crustal strain east of the Himalaya: Journal of Geophysical Research, Solid Earth , v. 106, B7, p. 13,697-13,709, https://doi-org.insu.bib.cnrs.fr/10.1029/2000JB900335. 
Harrison, T.M., Yin, A., and Ryerson, F.J., 1998, Orographic evolution of the Himalaya and Tibetan plateau: Oxford Monographs on Geology and Geophysics , v. 39, p. 39-72.

Jaeger, J.-J., Thein, T., Benammi, M., Chaimanee, Y., Soe, A.N., Lwin, T., et al, 1999, A new primate from the middle Eocene of Myanmar and the Asian early origin of anthropoids: Science, v. 286, no. 5439, p. 528-530, https://doiorg.insu.bib.cnrs.fr/10.1126/science.286.5439.528.

Khan, P.K., and Chakraborty, P.P., 2005, Two-phase opening of Andaman Sea: A new seismotectonic insight: Earth and Planetary Science Letters , v. 229, no. 3, p. 259271, https://doi-org.insu.bib.cnrs.fr/10.1016/j.epsl.2004.11.010.

Khin, K., and Myitta, 1999, Marine transgression and regression in Miocene sequences of northern Pegu (Bago) Yoma, Central Myanmar: Journal of Asian Earth Sciences , v. 17, no. 3, p. 369-393, http:/doi.org/10.1016/S0743-9547(98)00065-8.

Lee, H.Y., Chung, S.L., and Yang, H.M., 2016, Late Cenozoic volcanism in central Myanmar: Geochemical characteristics and geodynamic significance: Lithos , v. 245, p. 174190, https://doi-org.insu.bib.cnrs.fr/10.1016/j.lithos.2015.09.018.

Lee, T.Y., and Lawver, L.A., 1995, Cenozoic plate reconstruction of Southeast Asia: Tectonophysics , v. 251, no. 1-4, p. 85-138, https://doiorg.insu.bib.cnrs.fr/10.1016/0040-1951(95)00023-2.

Leeder, M.R., 2009, Sedimentology and Sedimentary Basins: From Turbulence to Tectonics: John Wiley \& Sons, $608 \mathrm{p}$.

Leever, K.A., Gabrielsen, R.H., Sokoutis, D., and Willingshofer, E., 2011, The effect of convergence angle on the kinematic evolution of strain partitioning in transpressional brittle wedges: Insight from analog modeling and high-resolution digital image analysis: Tectonics , v. 30, no. 2, https://doiorg.insu.bib.cnrs.fr/10.1029/2010TC002823.

Li, S., Advokaat, E.L., van Hinsbergen, D.J., Koymans, M., Deng, C., and Zhu, R., 2017, Paleomagnetic constraints on the Mesozoic-Cenozoic paleolatitudinal and rotational history of Indochina and South China: Review and updated kinematic reconstruction: Earth-Science Reviews , v. 171, p. 58-77, https://doiorg.insu.bib.cnrs.fr/10.1016/j.earscirev.2017.05.007.

Licht, A., 2013, Paléodrainage, paléoenvironnements et paléoclimats de l'Eocène birman: Implications sur l'origine et l'évolution précoce des anthropoïdes asiatiques [Ph.D. thesis]: France, University of Poitiers, $264 \mathrm{p}$.

Licht, A., Boura, A., De Franceschi, D., Ducrocq, S., Soe, A.N., and Jaeger, J.-J., 2014a, Fossil woods from the late middle Eocene Pondaung Formation, Myanmar: Review of Palaeobotany and Palynology, v. 202, p. 29-46, https://doiorg.insu.bib.cnrs.fr/10.1016/j.revpalbo.2013.12.002.

Licht, A., Boura, A., De Franceschi, D., Utescher, T., Sein, C., and Jaeger, J.-J., 2015, Late middle Eocene fossil wood of Myanmar: Implications for the landscape and the climate of the Eocene Bengal Bay: Review of Palaeobotany and Palynology , v. 216, p. 44-54, https://doi-org.insu.bib.cnrs.fr/10.1016/j.revpalbo.2015.01.010. 
Licht, A., Cojan, I., Caner, L., Soe, A.N., Jaeger, J., and France-Lanord, C., 2014b, Influence of permeability barriers in alluvial hydromorphic palaeosols: The Eocene Pondaung Formation, Myanmar: Sedimentology , v. 61, p. 362-382.

Licht, A., France-Lanord, C., Reisberg, L., Fontaine, C., Soe, A.N., and Jaeger, J.-J., 2013, A palaeo Tibet-Myanmar connection? Reconstructing the Late Eocene drainage system of central Myanmar using a multi-proxy approach: Journal of the Geological Society , v. 170, no. 6, p. 929-939, https://doiorg.insu.bib.cnrs.fr/10.1144/jgs2012-126.

Licht, A., Reisberg, L., France-Lanord, C., Soe, A.N., and Jaeger, J.-J., 2016, Cenozoic evolution of the central Myanmar drainage system: Insights from sediment provenance in the Minbu Sub-Basin: Basin Research , v. 28, no. 2, p. 237-251, https://doi-org.insu.bib.cnrs.fr/10.1111/bre.12108.

Licht, A., van Cappelle, M., Abels, H. A., Ladant, J., Trabucho-Alexandre, J., France-Lanord, C., Donnadieu, Y., Vandenberghe, J., Rigaudier, T., Lecuyer, C., Terry Jr., D., Adriaens, R., Boura, A., Guo, Z., Soe, A.N., Dupont-Nivet, G., and Jaeger, J.-J., 2014c, Asian monsoons in a late Eocene greenhouse world: Nature , v. 513, p. 501-506, https://doi-org.insu.bib.cnrs.fr/10.1038/nature13704.

Liu, C.Z., Chung, S.L., Wu, F.Y., Zhang, C., Xu, Y., Wang, J.G., et al, 2016, Tethyan suturing in Southeast Asia: Zircon U-Pb and Hf-O isotopic constraints from Myanmar ophiolites: Geology , v. 44, no. 4, p. 311-314, https://doiorg.insu.bib.cnrs.fr/10.1130/G37342.1.

Ludwig, K.R., 2003, User's manual for Isoplot 3.00: A Geochronological Toolkit for Microsoft Excel: Berkeley Geochronological Center Special Publication 4.

Ma, L., Wang, Y., Fan, W., Geng, H., Cai, Y., Zhong, H., et al, 2014, Petrogenesis of the early Eocene I-type granites in west Yingjiang (SW Yunnan) and its implication for the eastern extension of the Gangdese batholiths: Gondwana Research , v. 25, no. 1, p. 401-419.

Ma, Y., Yang, T., Bian, W., Jin, J., Zhang, S., Wu, H., and Li, H., 2016, Early Cretaceous paleomagnetic and geochronologic results from the Tethyan Himalaya: Insights into the Neotethyan paleogeography and the India-Asia collision: Scientific Reports , v. 6, 21605, https://doi-org.insu.bib.cnrs.fr/10.1038/srep21605.

Maffione, M., van Hinsbergen, D.J., Koornneef, L.M., Guilmette, C., Hodges, K., Borneman, N., et al, 2015, Forearc hyperextension dismembered the south Tibetan ophiolites: Geology , v. 43, p. 475-478, https://doi-org.insu.bib.cnrs.fr/10.1130/G36472.1.

Maung, H., 1987, Transcurrent movements in the Burma-Andaman Sea region: Geology , v. $15, \quad$ p. 911-912, https://doi-org.insu.bib.cnrs.fr/10.1130/00917613(1987)15<911:TMITBS>2.0.C0;2.

Maurin, T., and Rangin, C., 2009, Structure and kinematics of the Indo-Burmese Wedge: Recent and fast growth of the outer wedge: Tectonics , v. 28, no. 2, https://doiorg.insu.bib.cnrs.fr/10.1029/2008TC002276.

Maury, R.C., Pubellier, M., Rangin, C., Wulput, L., Cotten, J., Socquet, A., et al, 2004, Quaternary calc-alkaline and alkaline volcanism in an hyper-oblique convergence setting, central Myanmar and western Yunnan: Bulletin de la Société Géologique de 
France , v. 175, no. 5, p. 461-472, https://doiorg.insu.bib.cnrs.fr/10.2113/175.5.461.

McClay, K.R., Whitehouse, P.S., Dooley, T., and Richards, M., 2004, 3D evolution of fold and thrust belts formed by oblique convergence: Marine and Petroleum Geology , v. 21, no. 7, p. 857-877, https://doiorg.insu.bib.cnrs.fr/10.1016/j.marpetgeo.2004.03.009.

McQuarrie, N., Tobgay, T., Long, S.P., Reiners, P.W., and Cosca, M.A., 2014, Variable exhumation rates and variable displacement rates: Documenting recent slowing of Himalayan shortening in western Bhutan: Earth and Planetary Science Letters, v. 386, p. 161-174, https://doi-org.insu.bib.cnrs.fr/10.1016/j.epsl.2013.10.045.

Metcalfe, I., 2013, Gondwana dispersion and Asian accretion: tectonic and palaeogeographic evolution of eastern Tethys: Journal of Asian Earth Sciences , v. 66, p. 1-33, https://doi-org.insu.bib.cnrs.fr/10.1016/j.jseaes.2012.12.020.

Miall, A.D., 2013, The geology of fluvial deposits: sedimentary facies, basin analysis, and petroleum geology: Springer, 582 p., https://doi-org.insu.bib.cnrs.fr/10.1007/9783-662-03237-4.

Mitchell, A., Chung, S.L., Oo, T., Lin, T.H., and Hung, C.H., 2012, Zircon U-Pb ages in Myanmar: Magmatic-metamorphic events and the closure of a neo-Tethys ocean?: Journal of Asian Earth Sciences , v. 56, p. 1-23, https://doiorg.insu.bib.cnrs.fr/10.1016/j.jseaes.2012.04.019.

Mitchell, A.H.G., 1993, Cretaceous-Cenozoic tectonic events in the western Myanmar (Burma)-Assam region: Journal of the Geological Society , v. 150, no. 6, p. 10891102, https://doi-org.insu.bib.cnrs.fr/10.1144/gsigs.150.6.1089.

Mitchell, A.H.G., Htay, M.T., Htun, K.M., Win, M.N., Oo, T., and Hlaing, T., 2007, Rock relationships in the Mogok metamorphic belt, Tatkon to Mandalay, central Myanmar: Journal of Asian Earth Sciences , v. 29, no. 5, p. 891-910, https://doiorg.insu.bib.cnrs.fr/10.1016/j.jseaes.2006.05.009.

Molnar, P., England, P., and Martinod, J., 1993, Mantle dynamics, uplift of the Tibetan Plateau, and the Indian monsoon: Reviews of Geophysics , v. 31, no. 4, p. 357-396.

Morley, C.K., 2002, A tectonic model for the Tertiary evolution of strike-slip faults and rift basins in SE Asia: Tectonophysics , v. 347, no. 4, p. 189-215, https://doiorg.insu.bib.cnrs.fr/10.1016/S0040-1951(02)00061-6.

Morley, C.K., 2009, Evolution from an oblique subduction back-arc mobile belt to a highly oblique collisional margin: the Cenozoic tectonic development of Thailand and eastern Myanmar, in Cawood, P.A., and Kröner, A., eds., Earth Accretionary Systems in Space and Time : Geological Society of London Special Publication 318, no. 1, p. 373-403, https://doi-org.insu.bib.cnrs.fr/10.1144/SP318.14.

Morley, C.K., 2012, Late Cretaceous-early Palaeogene tectonic development of SE Asia: Earth-Science Reviews , v. 115, no. 1-2, p. 37-75, https://doiorg.insu.bib.cnrs.fr/10.1016/j.earscirev.2012.08.002.

Morley, C.K., 2017, Syn-kinematic sedimentation at a releasing splay in the northern Minwun Ranges, Sagaing Fault zone, Myanmar: Significance for fault timing and 
displacement: Basin Research , v. 29, S1, p. 684-700, https://doiorg.insu.bib.cnrs.fr/10.1111/bre.12201.

Mozley, P.S., and Wersin, P., 1992, Isotopic composition of siderite as an indicator of depositional environment: Geology, v. 20, no. 9, p. 817-820, https://doiorg.insu.bib.cnrs.fr/10.1130/0091-7613(1992)020<0817:ICOSAA>2.3.CO;2.

Myanmar Geosciences Society (MGS), 2014, Geological map of Myanmar, revised version: Myanmar Geosciences Society, Yangon.

Nagappa, Y., 1959, Foraminiferal biostratigraphy of the Cretaceous-Eocene succession in the India-Pakistan-Burma region: Micropaleontology , v. 5, no. 2, p. 145-177, https://doi-org.insu.bib.cnrs.fr/10.2307/1484208.

Najman, Y., 2006, The detrital record of orogenesis: A review of approaches and techniques used in the Himalayan sedimentary basins: Earth-Science Reviews , v. 74, no. 1-2, p. 1-72, org.insu.bib.cnrs.fr/10.1016/j.earscirev.2005.04.004.

Najman, Y., Appel, E., Boudagher-Fadel, M., Bown, P., Carter, A., Garzanti, E., et al, 2010, Timing of India-Asia collision: Geological, biostratigraphic, and palaeomagnetic constraints: Journal of Geophysical Research, Solid Earth , v. 115, B12, https://doiorg.insu.bib.cnrs.fr/10.1029/2010JB007673.

Najman, Y., Jenks, D., Godin, L., Boudagher-Fadel, M., Millar, I., Garzanti, E., et al, 2017, The Tethyan Himalayan detrital record shows that India-Asia terminal collision occurred by $54 \mathrm{Ma}$ in the Western Himalaya: Earth and Planetary Science Letters , v. 459, p. 301-310, https://doi-org.insu.bib.cnrs.fr/10.1016/j.epsl.2016.11.036.

Nichols, G., 2009, Sedimentology and stratigraphy: Oxford, John Wiley \& Sons, 355 p.

Nielsen, C., Chamot-Rooke, N., and Rangin, C., 2004, From partial to full strain partitioning along the Indo-Burmese hyper-oblique subduction: Marine Geology , v. 209, no. 1-4, p. 303-327, https://doiorg.insu.bib.cnrs.fr/10.1016/j.margeo.2004.05.001.

Oo, K.L., Zaw, K., Meffre, S., Aung, D.W., and Lai, C.K., 2015, Provenance of the Eocene sandstones in the southern Chindwin Basin, Myanmar: Implications for the unroofing history of the Cretaceous-Eocene magmatic arc: Journal of Asian Earth Sciences , v. 107, p. 172-194, https://doiorg.insu.bib.cnrs.fr/10.1016/j.jseaes.2015.04.029.

Paton, C., Woodhead, J., Hellstrom, J., Hergt, J., Greig, A., and Maas, R., 2010, Improved laser ablation $\mathrm{U}-\mathrm{Pb}$ zircon geochronology through robust down-hole fractionation correction: Geochemistry Geophysics Geosystems , v. 11, no. 3, https://doiorg.insu.bib.cnrs.fr/10.1029/2009GC002618.

Pivnik, D.A., Nahm, J., Tucker, R.S., Smith, G.O., Nyein, K., Nyunt, M., and Maung, P.H., 1998, Polyphase deformation in a fore-arc/back-arc basin, Salin subbasin, Myanmar (Burma): AAPG Bulletin , v. 82, no. 10, p. 1837-1856.

Pubellier, M., 2008, Structural Map of Eastern Eurasia: CCGM, Commission for the Geological Map of the World, Scale at equator 1:12,500,000, 1 sheet.

Rangin, C., Maurin, T., and Masson, F., 2013, Combined effects of Eurasia/Sunda oblique convergence and East-Tibetan crustal flow on the active tectonics of Burma: 
Journal of Asian Earth Sciences , v. 76, p. 185-194, https://doiorg.insu.bib.cnrs.fr/10.1016/j.jseaes.2013.05.018.

Rangin, C., Maw, W., Lwin, S., Naing, W., Mouret, C., Bertrand, G., and the G.I.A.C. Scientific Party, 1999, Cenozoic Pull-Apart basins in Central Myanmar: the trace of the path of India along the Western Margin of Sundaland [abs.]: Terra Nova , v. 4, p. 59.

Replumaz, A., and Tapponnier, P., 2003, Reconstruction of the deformed collision zone between India and Asia by backward motion of lithospheric blocks: Journal of Geophysical Research , v. 108, https://doiorg.insu.bib.cnrs.fr/10.1029/2001JB000661.

Replumaz, A., Guillot, S., Villaseñor, A., and Negredo, A.M., 2013, Amount of Asian lithospheric mantle subducted during the India/Asia collision: Gondwana Research , v. 24, no. 3, p. 936-945, https://doiorg.insu.bib.cnrs.fr/10.1016/j.gr.2012.07.019.

Replumaz, A., Negredo, A.M., Guillot, S., and Villaseñor, A., 2010, Multiple episodes of continental subduction during India/Asia convergence: Insight from seismic tomography and tectonic reconstruction: Tectonophysics , v. 483, no. 1, p. 125134, https://doi-org.insu.bib.cnrs.fr/10.1016/j.tecto.2009.10.007.

Richter, B., and Fuller, M., 1996, Palaeomagnetism of the Sibumasu and Indochina blocks: Implications for the extrusion tectonic model, in Hall, R., and Blundell, D., Tectonic Evolution of Southeast Asia : Geological Society of London, Special Publication 106, no. 1, p. 203-224, https://doiorg.insu.bib.cnrs.fr/10.1144/GSL.SP.1996.106.01.13.

Robinson, R.A., Brezina, C.A., Parrish, R.R., Horstwood, M.S., Oo, N.W., Bird, M.I., et al, 2014, Large rivers and orogens: The evolution of the Yarlung Tsangpo-Irrawaddy system and the eastern Himalayan syntaxis: Gondwana Research , v. 26, no. 1, p. 112-121, https://doi-org.insu.bib.cnrs.fr/10.1016/j.gr.2013.07.002.

Roy, P.S., Cowell, P.J., Ferland, M.A., Thom, B.G., Carter, R.W.G., and Woodroffe, C.D., 1994, Wave-dominated coasts, in Carter, R.W.G., and Woodroffe, C.D., eds., Coastal Evolution: Late Quaternary Shoreline Morphodynamics : Cambridge University Press, p. 121-186.

Royden, L.H., Burchfiel, B.C., and van der Hilst, R.D., 2008, The geological evolution of the Tibetan Plateau: Science , v. 321, p. 1054-1058, https://doiorg.insu.bib.cnrs.fr/10.1126/science.1155371.

Sato, K., Liu, Y., Zhu, Z., Yang, Z., and Otofuji, Y.I., 2001, Tertiary paleomagnetic data from northwestern Yunnan, China: Further evidence for large clockwise rotation of the Indochina block and its tectonic implications: Earth and Planetary Science Letters , v. 185 , no. 1 , p. 185-198, https://doi-org.insu.bib.cnrs.fr/10.1016/S0012821X(00)00377-0.

Searle, M., Corfield, R.I., Stephenson, B.E.N., and McCarron, J.O.E., 1997, Structure of the North Indian continental margin in the Ladakh-Zanskar Himalayas: implications for the timing of obduction of the Spontang ophiolite, India-Asia collision and deformation events in the Himalaya: Geological Magazine , v. 134, no. 3, p. 297316, https://doi-org.insu.bib.cnrs.fr/10.1017/S0016756897006857. 
Searle, M.P., Morley, C.K., Waters, D.J., Gardiner, N.J., Htun, U.K., Nu, T.T., and Robb, L.J., 2017, Tectonic and metamorphic evolution of the Mogok Metamorphic and Jade Mines belts and ophiolitic terranes of Burma (Myanmar), in Barber, A.J., Zaw, K., and Crow, M.J., eds., Myanmar: Geology, Resources and Tectonics : Geological Society of London Memoir 48, p. 261-293.

Searle, M.P., Noble, S.R., Cottle, J.M., Waters, D.J., Mitchell, A.H.G., Hlaing, T., and Horstwood, M.S.A., 2007, Tectonic evolution of the Mogok metamorphic belt, Burma (Myanmar) constrained by U-Th-Pb dating of metamorphic and magmatic rocks: Tectonics , v. 26, no. 3, https://doiorg.insu.bib.cnrs.fr/10.1029/2006TC002083.

Searle, M.P., Whitehouse, M.J., Robb, L.J., Ghani, A.A., Hutchison, C.S., Sone, M., et al, 2012, Tectonic evolution of the Sibumasu-Indochina terrane collision zone in Thailand and Malaysia: Constraints from new $\mathrm{U}-\mathrm{Pb}$ zircon chronology of SE Asian tin granitoids: Journal of the Geological Society , v. 169, no. 4, p. 489-500, https://doiorg.insu.bib.cnrs.fr/10.1144/0016-76492011-107.

Seton, M., Müller, R.D., Zahirovic, S., Gaina, C., Torsvik, T., Shephard, G., et al, 2012, Global continental and ocean basin reconstructions since 200 Ma: Earth-Scientific Review (Singapore) , v. 113, no. 3-4, p. 212-270.

Sevastjanova, I., Hall, R., Rittner, M., Paw, S.M.T.L., Naing, T.T., Alderton, D.H., and Comfort, G., 2016, Myanmar and Asia united, Australia left behind long ago: Gondwana Research v. 32, p. http://doi.org.insu.bib.cnrs.fr/10.1016/j.gr.2015.02.001.

Shen, F., Royden, L.H., and Burchfiel, B.C., 2001, Large-scale crustal deformation of the Tibetan Plateau: Journal of Geophysical Research , v. 106, B4, p. 6793-6816, https://doi-org.insu.bib.cnrs.fr/10.1029/2000JB900389.

Socquet, A., Goffé, B., Pubellier, M., and Rangin, C., 2002, Le métamorphisme TardiCrétacé à Éocène des zones internes de la chaîne Indo-Birmane (Myanmar occidental): implications géodynamiques: Comptes Rendus Geoscience , v. 334, no. 8, p. 573-580, https://doi-org.insu.bib.cnrs.fr/10.1016/S1631-0713(02)01796-0.

Socquet, A., Vigny, C., Chamot-Rooke, N., Simons, W., Rangin, C., and Ambrosius, B., 2006, India and Sunda plates motion and deformation along their boundary in Myanmar determined by GPS: Journal of Geophysical Research. Solid Earth , v. 111, B5, https://doi-org.insu.bib.cnrs.fr/10.1029/2005JB003877.

Tapponnier, P., Peltzer, G., Le Dain, A.Y., Armijo, R., and Cobbold, P., 1982, Propagating extrusion tectonics in Asia: New insights from simple experiments with plasticine: Geology , v. 10, no. 12, p. 611-616, https://doi-org.insu.bib.cnrs.fr/10.1130/00917613(1982)10<611:PETIAN>2.0.C0;2.

Tessier, B., Archer, A.W., Laniere, W., and Feldman, H.R., 1995, Comparison of ancient tidal rhythmites (Carboniferous of Kansas and Indiana, USA) with modern analogues (the Bay of Mont-Saint-Michel, France), in Flemming B.W., and Bartholomä, A., eds., Tidal Signatures in Modern and Ancient Sediments: Special Publication of the International Association of Sedimentologists 24 , p. 259-271. 
Thein, M., and Maung, M., 2017, The Eastern (Back-arc) Basin of Central Myanmar: Basement rocks, lithostratigraphic units, palaeocurrents, provenance and developmental history, in Barber, A.J., Zaw, K., and Crow, M.J., eds., Myanmar: Geology, Resources and Tectonics: Geological Society of London Memoir 48, p. 169-183.

Tong, Y., Yang, Z., Jing, X., Zhao, Y., Li, C., Huang, D., and Zhang, X., 2016, New insights into the Cenozoic lateral extrusion of crustal blocks on the southeastern edge of Tibetan Plateau: Evidence from paleomagnetic results from Paleogene sedimentary strata of the Baoshan Terrane: Tectonics , v. 35, no. 11, p. 2494-2514, https://doi-org.insu.bib.cnrs.fr/10.1002/2016TC004221.

United Nations, 1978, Atlas of Stratigraphy Volume V: United Nations, ESCAP, New York. Valeton, I., 1994, Element concentration and formation of ore deposits by weathering: Catena , v. 21, no. 2-3, p. 99-129, https://doi-org.insu.bib.cnrs.fr/10.1016/03418162(94)90006-X.

van Hinsbergen, D.J., Kapp, P., Dupont-Nivet, G., Lippert, P.C., DeCelles, P.G., and Torsvik, T.H., 2011a, Restoration of Cenozoic deformation in Asia and the size of Greater India: Tectonics , v. 30, no. 5. TC5003, https://doiorg.insu.bib.cnrs.fr/10.1029/2011TC002908.

van Hinsbergen, D.J., Lippert, P.C., Dupont-Nivet, G., McQuarrie, N., Doubrovine, P.V., Spakman, W., and Torsvik, T.H., 2012, Greater India Basin hypothesis and a twostage Cenozoic collision between India and Asia: Proceedings of the National Academy of Sciences of the United States of America, v. 109, no. 20, p. 7659-7664.

van Hinsbergen, D.J., Steinberger, B., Doubrovine, P.V., and Gassmöller, R., 2011b, Acceleration and deceleration of India-Asia convergence since the Cretaceous: Roles of mantle plumes and continental collision: Journal of Geophysical Research, Solid Earth , v. 116, B6, https://doi-org.insu.bib.cnrs.fr/10.1029/2010JB008051.

Vérard, C., Stampfli, G., Borel, G., and Hochard, C., 2017, The Indian Promontory: A Bridge between Plate Tectonics and Life Evolution Models: Universal Journal of Geoscience , v. 5, no. 2, p. 25-32, https://doiorg.insu.bib.cnrs.fr/10.13189/ujg.2017.050202.

Vermeesch, P., 2013, Multi-sample comparison of detrital age distributions: Chemical Geology , v. 341, p. 140-146

Wang, J.G., Hu, X., Garzanti, E., An, W., and Liu, X.C., 2017, The birth of the Xigaze forearc basin in southern Tibet: Earth and Planetary Science Letters , v. 465, p. 38-47, https://doi-org.insu.bib.cnrs.fr/10.1016/j.epsl.2017.02.036.

Wang, J.G., Wu, F.Y., Tan, X.C., and Liu, C.Z., 2014, Magmatic evolution of the Western Myanmar Arc documented by $\mathrm{U}-\mathrm{Pb}$ and $\mathrm{Hf}$ isotopes in detrital zircon: Tectonophysics , v. 612, p. 97-105, https://doiorg.insu.bib.cnrs.fr/10.1016/j.tecto.2013.11.039.

Yin, A., and Harrison, T.M., 2000, Geologic evolution of the Himalayan-Tibetan orogen: Annual Review of Earth and Planetary Sciences, v. 28, no. 1, p. 211-280, https://doi-org.insu.bib.cnrs.fr/10.1146/annurev.earth.28.1.211. 
Yin, A., Harrison, T.M., Ryerson, F.J., Wenji, C., Kidd, W.S.F., and Copeland, P., 1994, Tertiary structural evolution of the Gangdese thrust system, southeastern Tibet: Journal of Geophysical Research, Solid Earth, v. 99, B9, p. 18,175-18,201, https://doi-org.insu.bib.cnrs.fr/10.1029/94JB00504.

Zaw, K., 1990, Geological, petrological and geochemical characteristics of granitoid rocks in Burma: With special reference to the associated W-Sn mineralization and their tectonic setting: Journal of Southeast Asian Earth Sciences , v. 4, no. 4, p. 293-335, https://doi-org.insu.bib.cnrs.fr/10.1016/0743-9547(90)90004-W.

Zhang, J.E., Xiao, W., Windley, B.F., Cai, F., Sein, K., and Naing, S., 2017b, Early Cretaceous wedge extrusion in the Indo-Burma Range accretionary complex: Implications for the Mesozoic subduction of Neotethys in SE Asia: International Journal of Earth Sciences , v. 106, no. 4, p. 1391-1408, https://doiorg.insu.bib.cnrs.fr/10.1007/s00531-017-1468-7.

Zhang, P., Mei, L., Hu, X., Li, R., Wu, L., Zhou, Z., and Qiu, H., 2017a, Structures, uplift, and magmatism of the Western Myanmar Arc: Constraints to mid-CretaceousPaleogene tectonic evolution of the western Myanmar continental margin: Gondwana Research , v. 52, p. 18-38, https://doiorg.insu.bib.cnrs.fr/10.1016/j.gr.2017.09.002. 
Alexis Licht, Guillaume Dupont-Nivet, Zaw Win, Hnin Hnin Swe, Myat Kaythi, Pierrick

Roperch, Tamas Ugrai, Virginia Littell, Diana Park, Jan Westerweel, Dominic Jones, Fernando Poblete, Day Wa Aung, Huasheng Huang, Carina Hoorn, and Kyaing Sein, 2019, Paleogene evolution of the Burmese forearc basin and implications for the history of India-Asia convergence: GSA Bulletin, https://doi.org/10.1130/B35002.1.

$\mathrm{U}-\mathrm{Pb}$ dating methods at the University of Washington

Figures DR1-DR3

Tables DR1-DR3 


\section{Supplementary methods - U-Pb dating methods at the University of Washington}

Zircon crystals are extracted from 1 to $5 \mathrm{~kg}$ samples by traditional methods of crushing and grinding, followed by separation with a Wilfley table, heavy liquids, and a Frantz magnetic separator at the University of Washington. A split of 100 to 1000 zircon crystals, is separated to include all grain sizes, is incorporated into a 1" epoxy mount together with fragments of the Plesovice International standard zircon (Slama et al., 2008) and fragment of our internal standard zircon, GHB, coming from the Hypersolvus granite of the Golden Horn Batholith of the North Cascades (Eddy et al., 2016). The mounts are polished, imaged with a backscattered electron detector (BSE) with our in-house, JEOL 733 Superprobe microprobe to distinguish zircons from other remaining heavy minerals, and polished again prior to isotopic analysis.

$\mathrm{U}-\mathrm{Pb}$ geochronology of zircons was conducted by laser ablation inductively coupled plasma mass spectrometry (LA-ICPMS) at the University of Washington. The analyses involve ablation of zircon with an Analyte G2 excimer laser (operating at a wavelength of $193 \mathrm{~nm}$ ) using a spot diameter of 25 microns, $10 \mathrm{~Hz}$ pulse repetition rate and an energy fluence of $4.12 \mathrm{~J} \mathrm{~cm}^{-2}$. The ablated material is carried in helium and mixed with nitrogen into the plasma source of an iCAP RQ Quadrupole ICP-MS. Analyzed masses include ${ }^{238} \mathrm{U},{ }^{235} \mathrm{U},{ }^{232} \mathrm{Th},{ }^{207} \mathrm{~Pb},{ }^{206} \mathrm{~Pb}$, and ${ }^{204} \mathrm{~Pb}$, with a total, combined dwell time of $\sim 0.4 \mathrm{~s}$. Each analysis consists of a $10 \mathrm{~s}$ integration on peaks with the laser off (for background), $38 \mathrm{~s}$ of acquisition with the laser firing, and a $17 \mathrm{~s}$ delay to purge the previous sample and prepare for the next analysis.

Data reduction is conducted with Iolite, using their Geochron Data Reduction Scheme to get U-Pb ages uncorrected for common lead (Paton et al., 2010), and the Andersen Routine of the Vizualage Data Reduction scheme (Chew et al., 2014), for $\mathrm{U}-\mathrm{Pb}$ ages corrected for common lead. To ensure grains with a complex history (e.g., inheritance, $\mathrm{Pb}$ loss, or overgrowths, detectable amount of ${ }^{204} \mathrm{~Pb}$ ) do not compromise data quality, the time-resolved pattern of ${ }^{206} \mathrm{~Pb}$ ${ }^{238} \mathrm{U}$ is monitored closely during data reduction, and any analyses that show abnormal patterns (e.g., different fractionation from standards or jumps in value) are rejected (Gehrels et al., 2011).

Data are provided in three formats: measured isotopic ratios (already corrected for downhole fraction and instrument bias with Iolite), U-Pb ages uncorrected for common lead, and U-Pb ages corrected for common lead with the Andersen routine. For each analysis, the errors in determining ${ }^{206} \mathrm{~Pb} /{ }^{238} \mathrm{U}$ result in a measurement error of $\sim 1-3 \%$ (at 2-sigma) in the ${ }^{206} \mathrm{~Pb} /{ }^{238} \mathrm{U}$ age. The errors in measurement of ${ }^{206} \mathrm{~Pb} / 207 \mathrm{~Pb}$ also result in $\sim 1-3 \%$ uncertainty (at 2sigma) in age for grains that are $>1.0 \mathrm{Ga}$, but are substantially larger for younger grains due to low intensity of the ${ }^{207} \mathrm{~Pb}$ signal. The crossover in precision of ${ }^{206} \mathrm{~Pb} /{ }^{238} \mathrm{U}$ and ${ }^{206} \mathrm{~Pb} /{ }^{207} \mathrm{~Pb}$ ages occurs at $\sim 1.2 \mathrm{Ga}$. The best age for every analysis is thus determined from ${ }^{206} \mathrm{~Pb} /{ }^{238} \mathrm{U}$ age for analyses with ${ }^{206} \mathrm{~Pb} /{ }^{238} \mathrm{U}$ age $<1.2 \mathrm{Ga}$ and from ${ }^{206} \mathrm{~Pb} /{ }^{207} \mathrm{~Pb}$ age for analyses with ${ }^{206} \mathrm{~Pb} /{ }^{238} \mathrm{U}$ age $>1.2 \mathrm{Ga}$. 7. Analyses with $>20 \%$ discordance ( $<80 \%$ concordance), as well with $>5 \%$ reverse discordance $(<105 \%$ concordance) are included but are marked as 'discordant' if the grains are older than $500 \mathrm{Ma}$ and should be used with caution.

The accuracy of our protocol is regularly tested with our secondary standard GHB and a set of 8 international standards provided by the Arizona Laserchron facility, including FCT, Temora2, OG1, R33, TarBra, Oracle, 91500, and 9435 (contact the Laserchron for more information about ages and origin). Over one year of analysis, the average offset to the TIMS U-Pb age value for our determined ages uncorrected for common lead is less than $0.5 \%$ for half of them (FCT, oracle, Tarbra, OG1) less than 1.5\% for others (R33, 91500, Temora2, GHB); only the Paleogene 9435 standard displays a higher average offset (2.3\%), but this standard also displays high age variability when analyzed with a Multi-collector ICP-MS (Mark Pecha, Laserchron, pers. com; Gehrels et al., 2008). Ages corrected for common lead with the Andersen routine display a commonly bigger offset $(\sim 1.5 \%$, but up to $3-5 \%$ for Proterozoic grains). We thus recommend to use the ages uncorrected for common lead.

The uncertainty resulting from the calibration correction is generally $1-2 \%$ (2-sigma) for both ${ }^{206} \mathrm{~Pb} / 207 \mathrm{~Pb}$ and ${ }^{206} \mathrm{~Pb}$ ${ }^{238} \mathrm{U}$ ages. Uncertainties from this calibration correction are not included in the age uncertainties provided in the supplementary material and should be combined (quadratically) with the uncertainty of the age of the standard to yield an external uncertainty for each sample. This external uncertainty is reported in the auxiliary material table with our data and provides a minimum uncertainty for each set of analyses. 


\section{References:}

Chew, D.M., Petrus, J.A. and Kamber, B.S. (2014), U-Pb LA-ICPMS dating using accessory mineral standards with variable common $\mathrm{Pb}$. Chemical Geology, 363: 185-199

Eddy, M. P., Bowring, S. A., Miller, R. B., \& Tepper, J. H. (2016). Rapid assembly and crystallization of a fossil large-volume silicic magma chamber. Geology, 44(4), 331-334.

Gehrels, G. E., Valencia, V. A., \& Ruiz, J. (2008). Enhanced precision, accuracy, efficiency, and spatial resolution of $\mathrm{U}-\mathrm{Pb}$ ages by laser ablation-multicollector-inductively coupled plasma-mass spectrometry. Geochemistry, Geophysics, Geosystems, 9(3).

Gehrels, G., Kapp, P., DeCelles, P., Pullen, A., Blakey, R., Weislogel, A., ... \& Yin, A. (2011). Detrital zircon geochronology of pre-Tertiary strata in the Tibetan-Himalayan orogen. Tectonics, 30(5).

Paton, C., Woodhead, J., Hellstrom, J., Hergt, J., Greig, A. and Maas, R (2010) Improved laser ablation U-Pb zircon geochronology through robust down-hole fractionation correction. Geochemistry, Geophysics, Geosystems, 11(3), doi:10.1029/2009GC002618

Sláma, J., Košler, J., Condon, D. J., Crowley, J. L., Gerdes, A., Hanchar, J. M., ... \& Schaltegger, U. (2008). Plešovice zircon-a new natural reference material for $\mathrm{U}-\mathrm{Pb}$ and $\mathrm{Hf}$ isotopic microanalysis. Chemical Geology, 249(1-2), 1-35. 
Paleogene evolution of the Burmese forearc basin and implications for the history of India-Asia convergence

Alexis Licht, Guillaume Dupont-Nivet, Zaw Win, Hnin Hnin Swe, Myat Kaythi, Pierrick Roperch, Tamas Ugrai, Virginia Littell, Diana Park, Jan Westerweel, Dominic Jones, Fernando Poblete, Day Wa Aung, Huasheng Huang, Carina Hoorn, and Kyaing Sein

\section{Supplementary Figures}



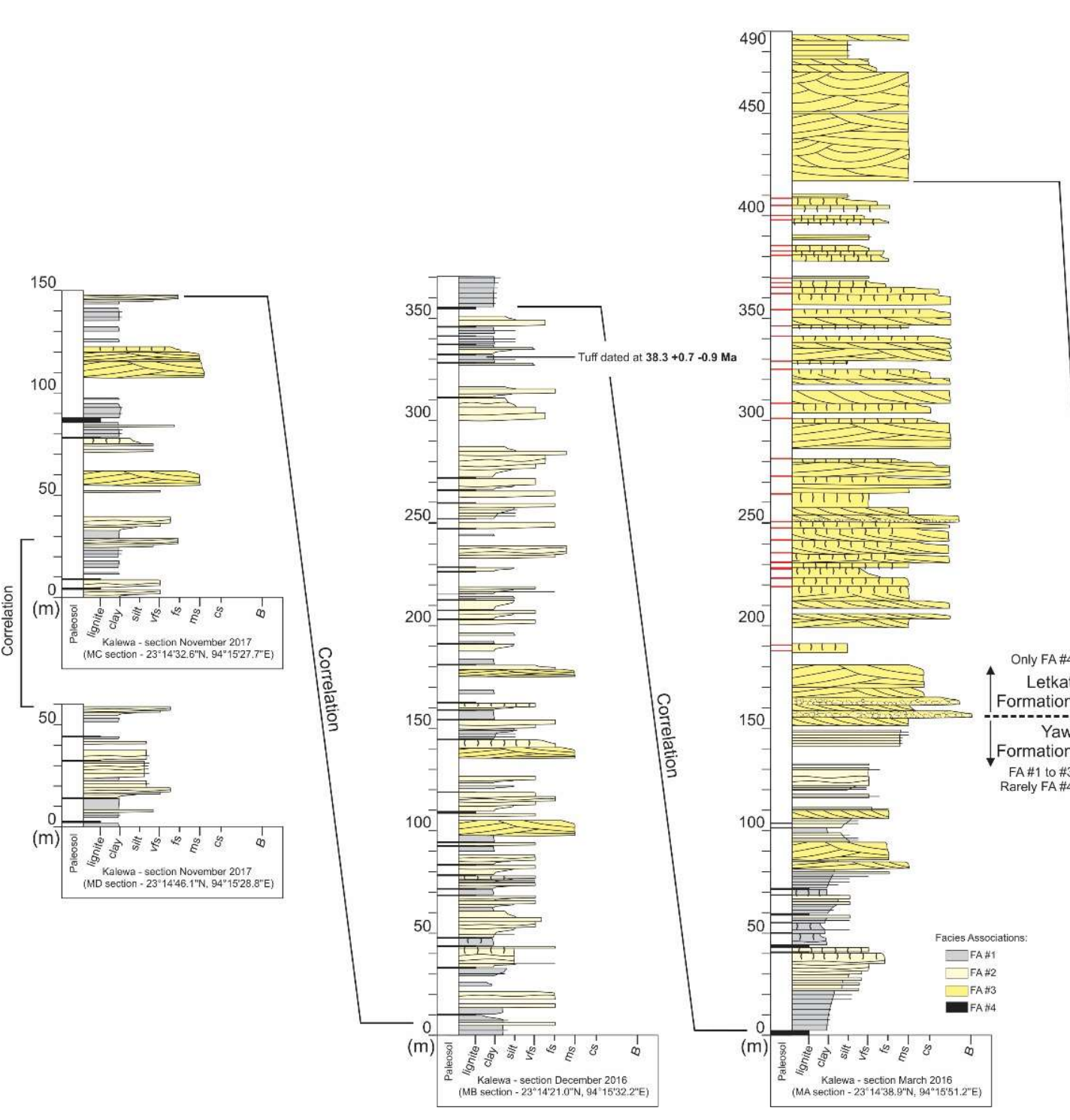

\section{Supplementary Figure DR1:}

Detailed logs of the Yaw and

Letkat Formations, with associated facies associations, and their correlations (correlations were made in the field by following marker beds, distance between sections is $\sim 200$ to $2000 \mathrm{~m}$ ).

Stratigraphic sections MA to MD were measured at the $10-\mathrm{cm}$ scale using a Jacob Staff, stratigraphic section LA weas measured at the 1-m scale. The base of MD section is approximatively $\sim 500 \mathrm{~m}$ above the transition between the

Pondaung and the Yaw Formation, marked by the appearance of the first lignites. The top of LA section is $\sim 700 \mathrm{~m}$ below the transition from the Letkat to the Natma Formation, which is gradual and marked by an increased in finegrained, pedogenised deposits. 

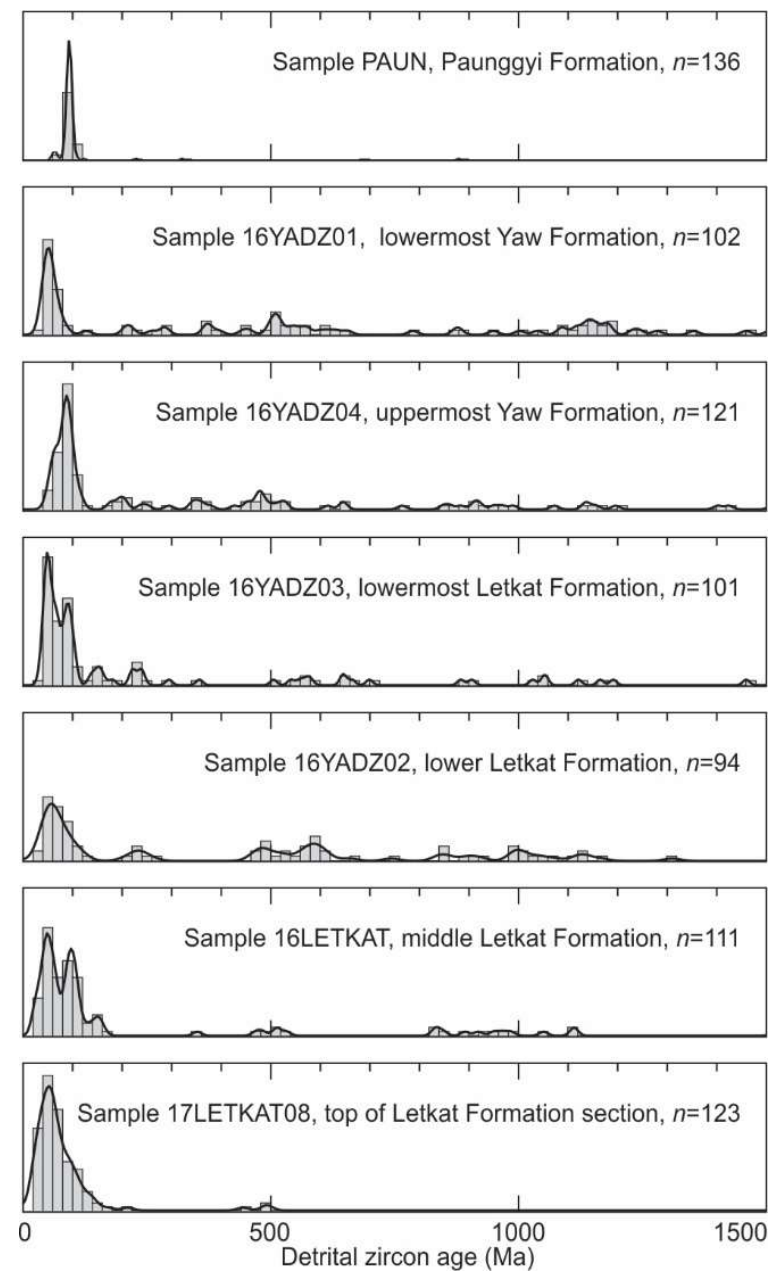

Supplementary Figure DR2: Kernel density estimators (KDE) and histograms (20 Myr bins) for the seven detrital sandstones presented in this study. The kernel density bandwidth of each plot was determined with plug-in bandwidth selection method of Botev et al. (2010). Stratigraphic and geographic location of the samples is given in supplementary table 2. 

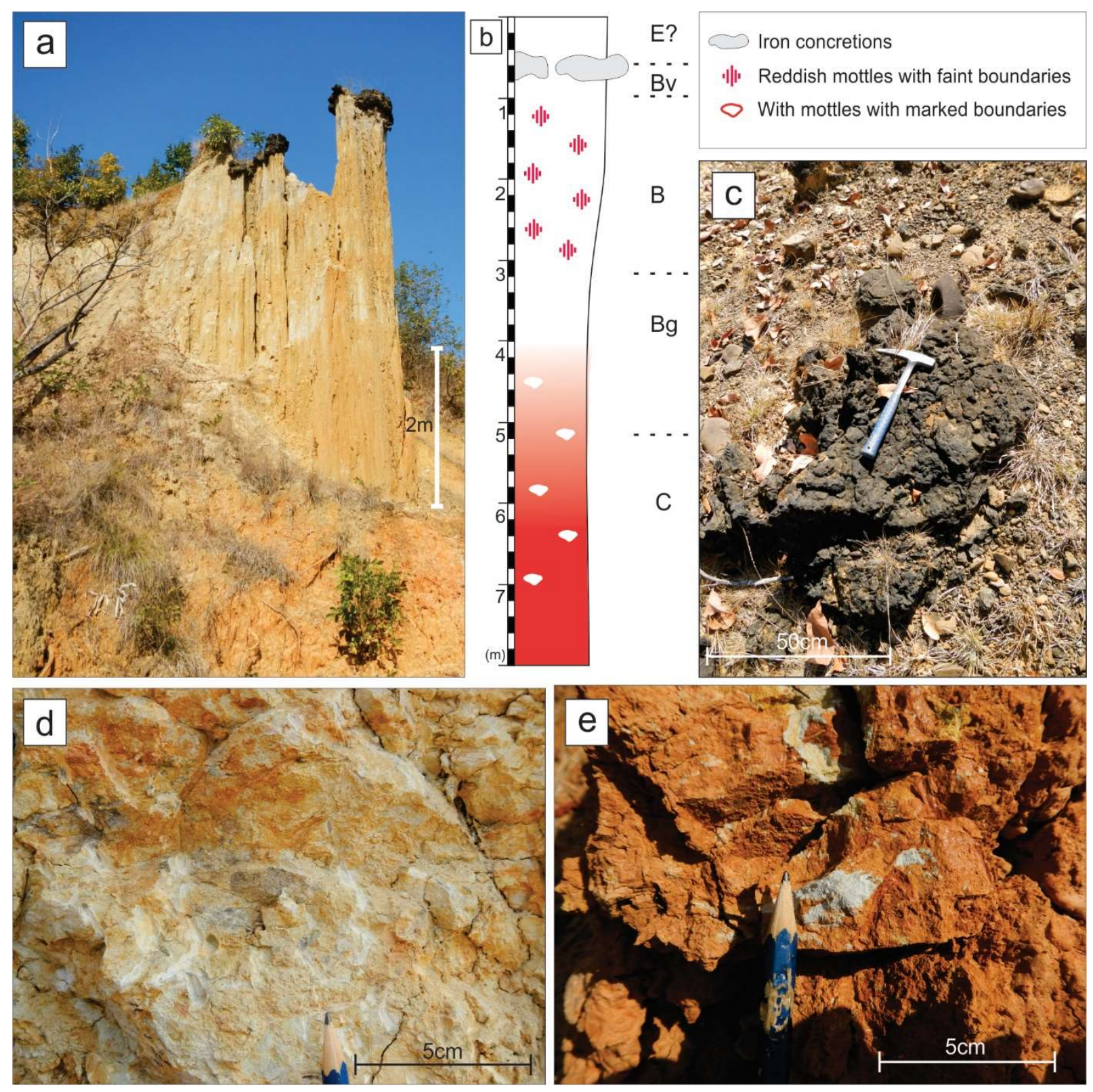

Supplementary Figure DR3: (a) Ferralitic paleosol developed in Eocene clastics below the Maw Gravels near Gangaw, eastern edge of the Indo-Burman Ranges (After Licht, 2013). (b) interpreted profile with pedogenic horizons. (c) Iron concretions in petroplinthic horizon Bv. (d) red mottles in the Bg horizon; (e) White mottles in the $\mathrm{C}$ horizon. 
Table DR1 - Lignite Sulfur results

\begin{tabular}{|c|c|c|c|c|c|c|c|c|}
\hline Sample & Strati & $\begin{array}{c}\text { PeakArea } \\
\text { (Vs) }\end{array}$ & Percent S & $\begin{array}{l}\text { Percent S } \\
\text { Accuracy }\end{array}$ & $\begin{array}{l}\text { Percent S } \\
\text { Precision }\end{array}$ & $\begin{array}{l}\text { d34S vs } \\
\text { VCDT } \\
\text { (permil) }\end{array}$ & $\begin{array}{c}\text { d34S } \\
\text { Accuracy }\end{array}$ & $\begin{array}{c}\text { d34S } \\
\text { Precision }\end{array}$ \\
\hline 16MBOM48 & $48 \mathrm{~m}$ in $\mathrm{MB}$ section & 18.949 & 0.4683 & -0.044993 & 0.12518 & 1.7094 & -0.26587 & 0.071155 \\
\hline YA160M68 & $68 \mathrm{~m}$ in MA section & 241.482 & 5.1633 & -0.044993 & 0.12518 & 5.4165 & -0.26587 & 0.071155 \\
\hline 16MBOM355 & $355 \mathrm{~m}$ in $\mathrm{MB}$ section & 16.785 & 0.42264 & -0.044993 & 0.12518 & 3.5212 & -0.26587 & 0.071155 \\
\hline 16МBOM93 & $93 \mathrm{~m}$ in $\mathrm{MB}$ section & 26.372 & 0.64143 & -0.044993 & 0.12518 & -0.66048 & -0.26587 & 0.071155 \\
\hline 16МBOM329 & $329 \mathrm{~m}$ in MB section & 50.436 & 1.1414 & -0.044993 & 0.12518 & -2.7313 & -0.26587 & 0.071155 \\
\hline 16MBOM266 & $266 \mathrm{~m}$ in $\mathrm{MB}$ section & 23.151 & 0.56195 & -0.044993 & 0.12518 & 1.3519 & -0.26587 & 0.071155 \\
\hline 16MBOM247 & $247 \mathrm{~m}$ in MB section & 15.086 & 0.39296 & -0.044993 & 0.12518 & 0.054964 & -0.26587 & 0.071155 \\
\hline 16МBOM163 & $163 \mathrm{~m}$ in MB section & 18.983 & 0.46828 & -0.044993 & 0.12518 & 0.92713 & -0.26587 & 0.071155 \\
\hline YA160M01 & $1 \mathrm{~m}$ in $\mathrm{MB}$ section & 14.848 & 0.37859 & -0.044993 & 0.12518 & 1.104 & -0.26587 & 0.071155 \\
\hline 16MBOM44 & $44 \mathrm{~m}$ in $\mathrm{MB}$ section & 50.378 & 1.1458 & -0.044993 & 0.12518 & -2.9935 & -0.26587 & 0.071155 \\
\hline 16МВОМ311 & $311 \mathrm{~m}$ in $\mathrm{MB}$ section & 26.982 & 0.65299 & -0.044993 & 0.12518 & 0.19105 & -0.26587 & 0.071155 \\
\hline 16MBOM345 & $345 \mathrm{~m}$ in $\mathrm{MB}$ section & 47.902 & 1.0841 & -0.044993 & 0.12518 & 1.7831 & -0.26587 & 0.071155 \\
\hline YA160M54 & $54 \mathrm{~m}$ in $\mathrm{MB}$ section & 113.778 & 2.5238 & -0.044993 & 0.12518 & 0.33143 & -0.26587 & 0.071155 \\
\hline YA160M33 & $33 \mathrm{~m}$ in $\mathrm{MB}$ section & 29.272 & 0.68432 & -0.044993 & 0.12518 & -6.4483 & -0.26587 & 0.071155 \\
\hline 16LIG01 & $\sim 350 \mathrm{~m}$ below MD section & 2.444 & 0.11841 & -0.044993 & 0.12518 & 1.2883 & -0.26587 & 0.071155 \\
\hline 17MCOM04 & $4 \mathrm{~m}$ in $\mathrm{MC}$ section & 7.314 & 0.3721 & -0.32544 & 0.13916 & 2.0312 & -0.16738 & 0.17854 \\
\hline 17MCOM09 & $9 \mathrm{~m}$ in $\mathrm{MC}$ section & 20.937 & 0.81862 & -0.32544 & 0.13916 & -9.1345 & -0.16738 & 0.17854 \\
\hline 17MCOM79 & $79 \mathrm{~m}$ in $\mathrm{MC}$ section & 43.148 & 1.6095 & -0.32544 & 0.13916 & -5.9663 & -0.16738 & 0.17854 \\
\hline 17MCOM87 & $87 \mathrm{~m}$ in $\mathrm{MC}$ section & 48.237 & 1.8406 & -0.32544 & 0.13916 & 4.9545 & -0.16738 & 0.17854 \\
\hline 17MDOM02 & $2 \mathrm{~m}$ in MD section & 18.389 & 0.71656 & -0.32544 & 0.13916 & -0.29152 & -0.16738 & 0.17854 \\
\hline 17MDOM13 & $13 \mathrm{~m}$ in MD section & 63.577 & 2.2279 & -0.32544 & 0.13916 & 15.4724 & -0.16738 & 0.17854 \\
\hline 17MDOM23 & $23 \mathrm{~m}$ in MD section & 8.82 & 0.38212 & -0.32544 & 0.13916 & -0.47639 & -0.16738 & 0.17854 \\
\hline 17MDOM31 & $21 \mathrm{~m}$ in MD section & 79.852 & 2.6932 & -0.32544 & 0.13916 & 7.0634 & -0.16738 & 0.17854 \\
\hline 17MDOM35 & $35 \mathrm{~m}$ in MD sction & 36.295 & 1.4328 & -0.32544 & 0.13916 & 19.3023 & -0.16738 & 0.17854 \\
\hline 17MDOM44 & $44 \mathrm{~m}$ in MD section & 4.724 & 0.23827 & -0.32544 & 0.13916 & 11.0702 & -0.16738 & 0.17854 \\
\hline
\end{tabular}


Table DR2 - Grain-counting results

\begin{tabular}{|c|c|c|c|c|c|c|c|c|c|c|c|c|}
\hline Sample & Stratigraphic location & Qm & Qp & Phylo leavy ppaqu & F & Lmeta & Lsed & Lcarb & Lvolc & Total \\
\hline 16LETKAT & $\begin{array}{c}\text { Letkat Fm, along the road, level } 80 m \text { in LA } \\
\text { section (sample for DZ U-Pb dating as well) }\end{array}$ & 194 & 20 & 14 & 14 & 4 & 12 & 14 & 41 & 0 & 7 & 320 \\
\hline PAUN & $\begin{array}{c}\text { Paunggyi Formation, along the road (sample for } \\
\text { DZ U-Pb dating as well) }\end{array}$ & 142 & 24 & 0 & 2 & 5 & 35 & 23 & 28 & 1 & 54 & 314 \\
\hline YA16DZ01 & $\begin{array}{c}\text { Very most base of the Yaw Formation, out of } \\
\text { the log (sample for DZ U-Pb dating as well) }\end{array}$ & 87 & 58 & 6 & 5 & 13 & 26 & 22 & 42 & 2 & 49 & 310 \\
\hline YA16DZ02 & $\begin{array}{c}\text { Level 271, MA section, middle of Letkat Fm } \\
\text { (sample for DZ U-Pb dating as well) }\end{array}$ & 186 & 17 & 6 & 4 & 4 & 13 & 26 & 42 & 0 & 23 & 321 \\
\hline YA16DZ03 & $\begin{array}{c}\text { Level 181, MA section, base of Letkat Fm } \\
\text { (sample for DZ U-Pb dating as well) }\end{array}$ & 182 & 19 & 7 & 8 & 5 & 17 & 34 & 40 & 0 & 36 & 348 \\
\hline YA16DZ04 & $\begin{array}{c}\text { Level 85, MA section, sandstone below letkat } \\
\text { Fm (sample for DZ U-Pb dating as well) }\end{array}$ & 137 & 40 & 2 & 15 & 8 & 11 & 31 & 34 & 4 & 59 & 341 \\
\hline YA16QFL01 & Level 87, MA section (Yaw Fm) & 159 & 24 & 0 & 1 & 2 & 11 & 31 & 56 & 0 & 27 & 311 \\
\hline YA16QFL02 & level 34, MA section (Yaw Fm) & 131 & 26 & 0 & 6 & 11 & 29 & 29 & 56 & 0 & 57 & 345 \\
\hline YA16QFL03 & Level 371, MA section (Letkat Fm) & 213 & 21 & 5 & 7 & 6 & 27 & 19 & 26 & 0 & 21 & 345 \\
\hline YA16QFL05 & Level 321, MA section (Letkat Fm) & 216 & 44 & 0 & 3 & 3 & 12 & 18 & 27 & 0 & 17 & 340 \\
\hline YA16QFL06 & Level 221, MA section (Letkat Fm) & 203 & 9 & 5 & 14 & 3 & 10 & 22 & 46 & 1 & 28 & 341 \\
\hline YA16QFL09 & Level 486, MA section (Letkat Fm) & 186 & 25 & 7 & 7 & 6 & 33 & 15 & 29 & 1 & 4 & 313 \\
\hline 16MBQFL217 & Level 217, MB section (Yaw Fm) & 169 & 12 & 0 & 2 & 12 & 23 & 17 & 58 & 1 & 44 & 338 \\
\hline
\end{tabular}

\begin{tabular}{|c|c|c|c|c|c|}
\hline Q & F & L & Lm & Ls & LV \\
\hline 74.3 & 1.4 & 21.5 & 22.6 & 66.1 & 11.3 \\
\hline 54.1 & 1.6 & 34.5 & 21.9 & 26.7 & 51.4 \\
\hline 50.7 & 4.5 & 40.2 & 19.5 & 37.2 & 43.4 \\
\hline 66.1 & 1.3 & 29.6 & 28.6 & 46.2 & 25.3 \\
\hline 61.3 & 1.5 & 33.5 & 30.9 & 36.4 & 32.7 \\
\hline 56.0 & 2.5 & 40.5 & 25.0 & 27.4 & 47.6 \\
\hline 59.4 & 0.6 & 37.0 & 27.2 & 49.1 & 23.7 \\
\hline 47.9 & 3.4 & 43.3 & 20.4 & 39.4 & 40.1 \\
\hline 71.6 & 1.8 & 20.2 & 28.8 & 39.4 & 31.8 \\
\hline 77.8 & 0.9 & 18.6 & 29.0 & 43.5 & 27.4 \\
\hline 66.5 & 0.9 & 30.4 & 22.9 & 47.9 & 29.2 \\
\hline 72.0 & 2.0 & 16.7 & 31.3 & 60.4 & 8.3 \\
\hline 55.9 & 3.7 & 37.0 & 14.3 & 48.7 & 37.0 \\
\hline
\end{tabular}




\section{Table DR3 - U-Pb results}

Sample name

Location

YA16DZ01

$23^{\circ} 13^{\prime} 06.6^{\prime \prime} \mathrm{N}, 94^{\circ} 14^{\prime} 52.2^{\prime \prime} \mathrm{E}$

YA16DZ02 $23^{\circ} 13^{\prime} 42.6^{\prime \prime} \mathrm{N}, 94^{\circ} 15^{\prime} 58.7^{\prime \prime E}$

YA16DZ03 $23^{\circ} 13^{\prime} 42.6^{\prime \prime} \mathrm{N}, 94^{\circ} 15^{\prime} 58.7^{\prime \prime} \mathrm{E}$

YA16DZ04 $23^{\circ} 13^{\prime} 42.6^{\prime \prime} \mathrm{N}, 94^{\circ} 15^{\prime} 58.7^{\prime \prime E}$

LETKAT $23^{\circ} 11^{\prime} 32.1^{\prime \prime N}, 94^{\circ} 16^{\prime} 07.4^{\prime \prime E}$

17LETKAT08 $23^{\circ} 19^{\prime} 10.7^{\prime \prime} \mathrm{N}, 94^{\circ} 17^{\prime} 54.3^{\prime \prime E}$

PAUN $23^{\circ} 13^{\prime} 27.4^{\prime \prime} \mathrm{N}, 94^{\circ} 09^{\prime} 07.7^{\prime \prime E}$

16MBV01

\section{Description}

Very most base of the Yaw Formation, out of the log

Level 271, MA section, middle of Letkat Fm

Level 181, MA section, base of Letkat Fm

Level 85, MA section, sandstone below letkat Fm

Letkat $\mathrm{Fm}$, along the road, level $~ 80 \mathrm{~m}$ in LA section

Letkat $\mathrm{Fm}$, level $476 \mathrm{~m}$ in LA section

Paunggyi Formation

Tuff layer, level 332 in MB section

1. Measured ratios corrected for downhole fraction and instrument bias.

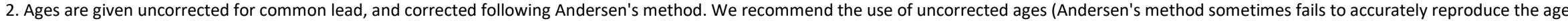
of international standards with our set up).

3. Best age is determined from $206 \mathrm{~Pb} / 238 \mathrm{U}$ age for analyses with $206 \mathrm{~Pb} / 238 \mathrm{U}$ age $<1200 \mathrm{Ma}$ and from $206 \mathrm{~Pb} / 207 \mathrm{~Pb}$ age for analyses with $206 \mathrm{~Pb} / 238 \mathrm{U}$ age $>1200 \mathrm{Ma}$.

4. All uncertainties include only measurement errors and are given in $2 \mathrm{~s}$.

5. additionnal systematic uncertainty during the sessions: $\sim 1.3 \%$.

6. Accuracy: observed offset for the ages of our secondary standards (R33 and GHB) during the sessions is in most of cases $<2 \%$, and in rare cases up to $4 \%$.

7. Analyses with $206 \mathrm{~Pb} / 238 \mathrm{U}$ age $>500 \mathrm{Ma}$ and with $>20 \%$ discordance $(<80 \%$ concordance) are included but are noted as discordant

8. Analyses with $206 \mathrm{~Pb} / 238 \mathrm{U}$ age $>500 \mathrm{Ma}$ and with $>5 \%$ reverse discordance ( $<105 \%$ concordance) are included but are noted as discordant

9. concordance is calculated between $206 \mathrm{~Pb} / 238 \mathrm{U}$ and $206 \mathrm{~Pb} / 207 \mathrm{~Pb}$ ages; 


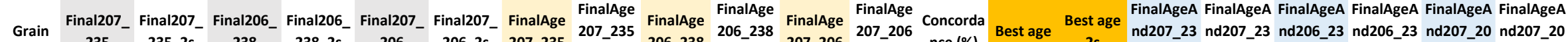

\begin{tabular}{|c|c|c|c|c|c|c|c|c|c|c|c|c|c|c|c|c|c|c|c|c|}
\hline & 235 & 235_25 & 238 & 238 - 25 & 206 & 206025 & 207_235 & $2 \mathrm{~s}$ & 200 _ 238 & $2 \mathrm{~s}$ & $201 / 206$ & $2 \mathrm{~s}$ & nce (\%) & 25 & 5 & $5 \_2 \mathrm{~s}$ & 8 & 8_2s & 6 & 6_2s \\
\hline Z001 & 0.754 & 0.018 & 0.0929 & 0.001 & 0.0591 & 0.0014 & 570 & 10 & 572.7 & 6 & 561 & 53 & -2.1 & 572.7 & 552.6 & 6.1 & 571.2 & 6.4 & 488 & 30 \\
\hline Z002 & 0.057 & 0.01 & 0.0078 & 0.00028 & 0.0472 & 0.0051 & 55.5 & 9.5 & 50.1 & 1.8 & 120 & 230 & 58.3 & 50.1 & 50 & 1.9 & 49.9 & 1.9 & 50.1 & 1.8 \\
\hline Z003 & 0.484 & 0.018 & 0.05982 & 0.00093 & 0.0591 & 0.0028 & 400 & 12 & 374.5 & 5.6 & 539 & 97 & 30.5 & 374.5 & 366.5 & 6.2 & 371.9 & 6.3 & 334 & 23 \\
\hline Z004 & 0.34 & 0.016 & 0.0456 & 0.00084 & 0.0534 & 0.0028 & 297 & 12 & 287.4 & 5.2 & 320 & 110 & 10.2 & 287.4 & 283.5 & 6.1 & 286.5 & 5.7 & 245 & 26 \\
\hline Z005 & 1.688 & 0.071 & 0.159 & 0.0025 & 0.0754 & 0.0036 & 1002 & 26 & 951 & 14 & 1063 & 92 & 10.5 & 951.0 & 941 & 15 & 944 & 16 & 913 & 33 \\
\hline Z006 & 7.16 & 0.28 & 0.3902 & 0.007 & 0.1312 & 0.0051 & 2127 & 36 & 2123 & 32 & 2122 & 60 & 0.0 & 2122.0 & 2086 & 34 & 2112 & 36 & 2054 & 39 \\
\hline Z007 & 0.0612 & 0.0064 & 0.00794 & 0.0002 & 0.0542 & 0.0052 & 60.1 & 6.1 & 51 & 1.3 & 350 & 200 & 85.4 & 51.0 & 50.5 & 1.3 & 50.4 & 1.4 & 50.9 & 1.3 \\
\hline 2008 & 2.229 & 0.062 & 0.2015 & 0.0031 & 0.0806 & 0.0016 & 1188 & 20 & 1183 & 17 & 1206 & 40 & 1.9 & 1183.0 & 1166 & 19 & 1180 & 17 & 1139 & 23 \\
\hline 2009 & 0.938 & 0.051 & 0.1034 & 0.0017 & 0.0661 & 0.0037 & 668 & 26 & 634.3 & 9.6 & 760 & 110 & 16.5 & 634.3 & 612 & 12 & 629 & 11 & 566 & 36 \\
\hline Z010 & 0.0383 & 0.0048 & 0.0065 & 0.00015 & 0.0428 & 0.0056 & 38.1 & 4.7 & 41.79 & 0.95 & -100 & 220 & 141.8 & 41.8 & 42 & 1.1 & 42 & 1.1 & 41.79 & 0.95 \\
\hline Z011 & 0.0767 & 0.0033 & 0.01218 & 0.00081 & 0.0453 & 0.0018 & 75.1 & 3.1 & 78 & 5.1 & -15 & 75 & 620.0 & 78.0 & 78.3 & 5.3 & 78.2 & 5.3 & 73.4 & 7.2 \\
\hline Z012 & 0.133 & 0.01 & 0.0203 & 0.0003 & 0.0477 & 0.0037 & 126.1 & 9 & 129.5 & 1.9 & 90 & 150 & -43.9 & 129.5 & 129.5 & 2.1 & 129.7 & 2.1 & 127.6 & 3.8 \\
\hline Z014 & 0.0526 & 0.0061 & 0.0084 & 0.00025 & 0.0451 & 0.0056 & 51.9 & 5.9 & 53.9 & 1.6 & -20 & 220 & 369.5 & 53.9 & 54 & 1.7 & 54.1 & 1.8 & 53.8 & 1.7 \\
\hline 2015 & 0.32 & 0.049 & 0.0416 & 0.0013 & 0.0552 & 0.0087 & 274 & 37 & 262.5 & 8.1 & 330 & 290 & 20.5 & 262.5 & 260.6 & 9.4 & 261 & 9.7 & 257.7 & 9.7 \\
\hline Z016 & 2.19 & 0.14 & 0.1945 & 0.0054 & 0.0804 & 0.0045 & 1171 & 45 & 1145 & 29 & 1180 & 110 & 3.0 & 1145.0 & 1119 & 37 & 1138 & 30 & 1074 & 58 \\
\hline Z017 & 0.0487 & 0.0073 & 0.00792 & 0.00027 & 0.0443 & 0.0066 & 48.1 & 7 & 50.8 & 1.7 & -60 & 250 & 184.7 & 50.8 & 50.9 & 1.8 & 51 & 1.8 & 50.6 & 1.7 \\
\hline $\mathrm{Z} 018$ & 0.0425 & 0.0069 & 0.00722 & 0.00025 & 0.0436 & 0.0074 & 42.1 & 6.8 & 46.4 & 1.6 & -100 & 270 & 146.4 & 46.4 & 46.6 & 1.8 & 46.6 & 1.8 & 46.5 & 1.6 \\
\hline 2019 & 2.691 & 0.096 & 0.235 & 0.0051 & 0.0815 & 0.0032 & 1324 & 27 & 1361 & 27 & 1221 & 78 & -11.5 & discordantdiscordant & 1304 & 23 & 1357 & 28 & 1184 & 61 \\
\hline 2020 & 0.64 & 0.13 & 0.013 & 0.0013 & 0.328 & 0.048 & 468 & 80 & 83 & 8 & 3300 & 320 & 97.5 & $83.0 \quad 8.0$ & 57.6 & 6.4 & 51.7 & 3.7 & 270 & 170 \\
\hline 2021 & 2.26 & 0.13 & 0.2011 & 0.0037 & 0.0801 & 0.005 & 1194 & 42 & 1181 & 20 & 1170 & 120 & -0.9 & 1181.0 & 1144 & 27 & 1174 & 21 & 1059 & 81 \\
\hline 2022 & 3.917 & 0.088 & 0.2826 & 0.0044 & 0.0991 & 0.0018 & 1616 & 18 & 1604 & 22 & 1605 & 35 & 0.1 & 1605.0 & 1595 & 21 & 1600 & 23 & 1573 & 22 \\
\hline 2023 & 3.99 & 0.15 & 0.2801 & 0.0058 & 0.1015 & 0.002 & 1629 & 31 & 1591 & 29 & 1649 & 36 & 3.5 & 1649.0 & 1588 & 28 & 1584 & 29 & 1579 & 24 \\
\hline 2024 & 0.732 & 0.022 & 0.0888 & 0.0014 & 0.0589 & 0.0013 & 557 & 13 & 548.4 & 8.4 & 558 & 48 & 1.7 & 548.4 & 539 & 10 & 547.1 & 8.6 & 493 & 26 \\
\hline 2025 & 0.0495 & 0.0039 & 0.00684 & 0.00019 & 0.0525 & 0.0045 & 49 & 3.7 & 43.9 & 1.2 & 270 & 160 & 83.7 & 43.9 & 43.6 & 1.3 & 43.6 & 1.3 & 43.8 & 1.3 \\
\hline 2027 & 0.903 & 0.021 & 0.1076 & 0.0012 & 0.061 & 0.0014 & 653 & 11 & 658.5 & 7.2 & 629 & 51 & -4.7 & 658.5 & 643.4 & 8.3 & 657.4 & 7.4 & 577 & 36 \\
\hline 2028 & 2.075 & 0.06 & 0.1899 & 0.0049 & 0.0779 & 0.0014 & 1139 & 20 & 1120 & 26 & 1141 & 34 & 1.8 & 1120.0 & 1120 & 27 & 1118 & 28 & 1086 & 27 \\
\hline 2029 & 4.89 & 0.19 & 0.3255 & 0.0065 & 0.1083 & 0.0035 & 1797 & 32 & 1816 & 32 & 1760 & 61 & -3.2 & 1760.0 & 1769 & 35 & 1810 & 34 & 1706 & 51 \\
\hline 2030 & 1.327 & 0.052 & 0.1237 & 0.0033 & 0.078 & 0.0044 & 855 & 23 & 751 & 19 & 1130 & 110 & 33.5 & discordantdiscordant & 734 & 19 & 739 & 21 & 723 & 23 \\
\hline 2031 & 4.51 & 0.097 & 0.3033 & 0.0058 & 0.1062 & 0.0014 & 1732 & 18 & 1707 & 29 & 1734 & 24 & 1.6 & 1734.0 & 1704 & 27 & 1702 & 31 & 1683 & 25 \\
\hline 2032 & 0.098 & 0.04 & 0.00825 & 0.00062 & 0.081 & 0.029 & 91 & 33 & 52.9 & 4 & 690 & 520 & 92.3 & 52.9 & 49.5 & 3.7 & 49.4 & 3.7 & 52.9 & 4 \\
\hline 2033 & 0.35 & 0.033 & 0.04575 & 0.00099 & 0.0542 & 0.0048 & 303 & 25 & 288.4 & 6.1 & 340 & 180 & 15.2 & 288.4 & 286.1 & 6.1 & 287 & 5.8 & 276 & 16 \\
\hline Z034 & 0.66 & 0.013 & 0.0804 & 0.0012 & 0.0588 & 0.0011 & 514.4 & 8 & 498.4 & 7.4 & 556 & 41 & 10.4 & 498.4 & 495.3 & 6.6 & 496.8 & 7.5 & 471 & 19 \\
\hline 2035 & 13.99 & 0.23 & 0.5112 & 0.0075 & 0.199 & 0.0031 & 2747 & 16 & 2661 & 32 & 2816 & 25 & 5.5 & 2816.0 & 2645 & 34 & 2620 & 42 & 2671 & 32 \\
\hline 2036 & 2.092 & 0.052 & 0.194 & 0.003 & 0.0783 & 0.0012 & 1145 & 17 & 1143 & 16 & 1152 & 30 & 0.8 & 1143.0 & 1128 & 16 & 1140 & 17 & 1107 & 17 \\
\hline 2037 & 1.752 & 0.05 & 0.1692 & 0.0025 & 0.0752 & 0.0016 & 1026 & 18 & 1007 & 14 & 1068 & 45 & 5.7 & 1007.0 & 994 & 16 & 1003 & 14 & 968 & 26 \\
\hline 2038 & 0.805 & 0.029 & 0.099 & 0.001 & 0.0589 & 0.002 & 598 & 16 & 608.6 & 6 & 546 & 75 & -11.5 & discordanidiscordant & 585 & 11 & 607.4 & 6 & 490 & 47 \\
\hline 2039 & 0.079 & 0.014 & 0.00953 & 0.00099 & 0.0619 & 0.0072 & 77 & 13 & 61.1 & 6.3 & 580 & 230 & 89.5 & 61.1 & 57.5 & 3.8 & 57.5 & 3.8 & 61.1 & 6.3 \\
\hline 2040 & 0.082 & 0.016 & 0.0094 & 0.00038 & 0.063 & 0.011 & 79 & 15 & 60.3 & 2.4 & 540 & 360 & 88.8 & 60.3 & 59.1 & 2.8 & 59.1 & 2.8 & 60.1 & 2.5 \\
\hline 2041 & 0.326 & 0.063 & 0.01062 & 0.00061 & 0.211 & 0.035 & 274 & 48 & 68.1 & 3.9 & 2490 & 380 & 97.3 & 68.1 & 53.2 & 2.3 & 52.8 & 2.3 & 68.1 & 3.9 \\
\hline Z042 & 2.427 & 0.097 & 0.2085 & 0.0058 & 0.0819 & 0.0031 & 1249 & 29 & 1220 & 31 & 1235 & 78 & 1.2 & 1235.0 & 1207 & 31 & 1214 & 33 & 1162 & 58 \\
\hline Z043 & 0.058 & 0.012 & 0.008 & 0.00034 & 0.052 & 0.011 & 56 & 12 & 51.4 & 2.2 & 160 & 360 & 67.9 & 51.4 & 51 & 2.4 & 51 & 2.4 & 51.4 & 2.2 \\
\hline Z044 & 1.953 & 0.067 & 0.1838 & 0.0032 & 0.0754 & 0.0023 & 1098 & 23 & 1088 & 17 & 1072 & 61 & -1.5 & 1088.0 & 1075 & 19 & 1085 & 18 & 1020 & 39 \\
\hline Z045 & 0.675 & 0.019 & 0.08435 & 0.00084 & 0.0581 & 0.0017 & 523 & 12 & 522 & 5 & 522 & 61 & 0.0 & 522.0 & 504.2 & 6.4 & 520.5 & 5.2 & 433 & 30 \\
\hline Z046 & 0.0619 & 0.0063 & 0.0095 & 0.00024 & 0.0476 & 0.0049 & 60.8 & 6 & 61 & 1.5 & 80 & 190 & 23.8 & 61.0 & 61 & 1.6 & 61 & 1.6 & 61 & 1.5 \\
\hline Z047 & 0.0474 & 0.0069 & 0.00779 & 0.00025 & 0.0458 & 0.0072 & 46.8 & 6.7 & 50 & 1.6 & -30 & 250 & 266.7 & 50.0 & 50.1 & 1.6 & 50.1 & 1.6 & 50 & 1.6 \\
\hline Z048 & 2.165 & 0.082 & 0.1973 & 0.0032 & 0.0799 & 0.0033 & 1166 & 27 & 1161 & 17 & 1171 & 83 & 0.9 & 1161.0 & 1117 & 19 & 1154 & 19 & 1047 & 51 \\
\hline Z049 & 0.564 & 0.024 & 0.0718 & 0.0018 & 0.057 & 0.0019 & 453 & 16 & 447 & 11 & 474 & 73 & 5.7 & 447.0 & 435 & 11 & 446 & 11 & 377 & 32 \\
\hline
\end{tabular}




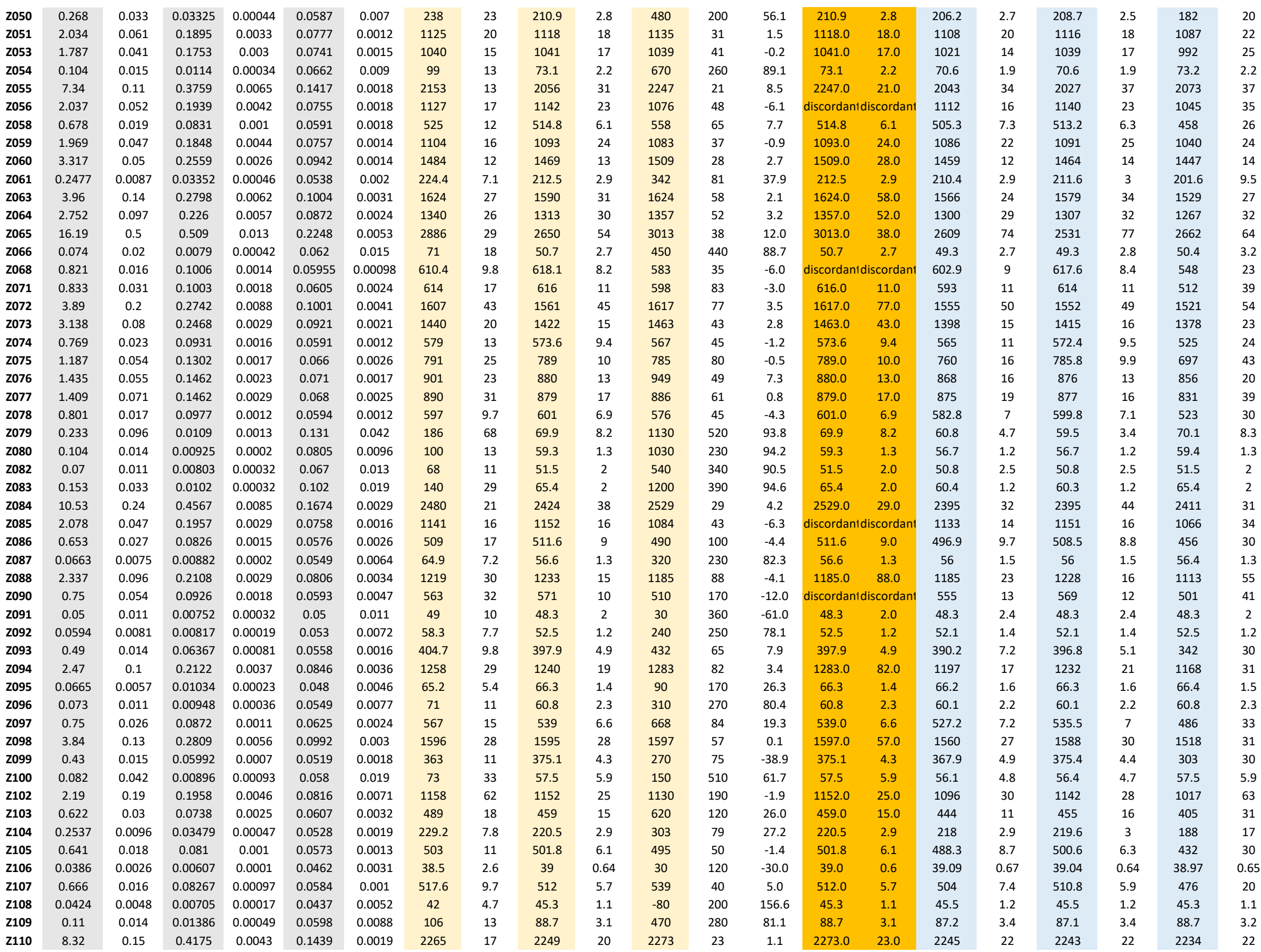




\begin{tabular}{|c|c|c|c|c|c|c|c|c|c|c|c|c|c|c|c|c|c|c|c|c|}
\hline Z111 & 11.7 & 0.17 & 0.4836 & 0.0038 & 0.1755 & 0.0025 & 2579 & 13 & 2543 & 17 & 2609 & 24 & 2.5 & 2609.0 & 24.0 & 2547 & 18 & 2530 & 22 & 2561 \\
\hline Z112 & 0.494 & 0.038 & 0.05953 & 0.00086 & 0.0614 & 0.005 & 410 & 27 & 372.7 & 5.2 & 570 & 150 & 34.6 & 372.7 & 5.2 & 367.2 & 5.3 & 369.2 & 4.8 & 350 \\
\hline Z113 & 0.0484 & 0.0036 & 0.00727 & 0.00016 & 0.0488 & 0.0036 & 47.9 & 3.4 & 46.7 & 1 & 130 & 140 & 64.1 & 46.7 & 1.0 & 46.6 & 1.1 & 46.6 & 1.1 & 46.5 \\
\hline Z114 & 0.736 & 0.035 & 0.0904 & 0.0011 & 0.0584 & 0.0026 & 558 & 20 & 558.2 & 6.5 & 540 & 100 & -3.4 & 558.2 & 6.5 & 534.3 & 9 & 556 & 7 & 437 \\
\hline Z115 & 0.06 & 0.011 & 0.00841 & 0.00029 & 0.0521 & 0.0098 & 58 & 11 & 54 & 1.9 & 150 & 320 & 64.0 & 54.0 & 1.9 & 53.7 & 2.1 & 53.7 & 2.1 & 54.1 \\
\hline Z116 & 2.505 & 0.091 & 0.2174 & 0.0061 & 0.0823 & 0.0022 & 1271 & 27 & 1268 & 33 & 1246 & 51 & -1.8 & 1246.0 & 51.0 & 1246 & 30 & 1264 & 34 & 1186 \\
\hline Z117 & 0.0621 & 0.0067 & 0.00782 & 0.00023 & 0.0563 & 0.0061 & 60.9 & 6.4 & 50.2 & 1.5 & 420 & 210 & 88.0 & 50.2 & 1.5 & 49.6 & 1.6 & 49.6 & 1.6 & 50.2 \\
\hline Z118 & 2.144 & 0.06 & 0.1979 & 0.003 & 0.0787 & 0.0022 & 1166 & 18 & 1164 & 16 & 1152 & 60 & -1.0 & 1164.0 & 16.0 & 1133 & 15 & 1160 & 17 & 1096 \\
\hline Z119 & 2.082 & 0.052 & 0.1932 & 0.0026 & 0.0779 & 0.0018 & 1141 & 17 & 1138 & 14 & 1137 & 45 & -0.1 & 1138.0 & 14.0 & 1113 & 11 & 1135 & 14 & 1090 \\
\hline Z120 & 0.653 & 0.033 & 0.0825 & 0.0011 & 0.0574 & 0.003 & 508 & 20 & 511.1 & 6.4 & 500 & 130 & -2.2 & 511.1 & 6.4 & 497.3 & 9.1 & 509.6 & 7.3 & 444 \\
\hline
\end{tabular}




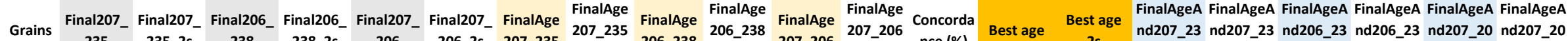

\begin{tabular}{|c|c|c|c|c|c|c|c|c|c|c|c|c|c|c|c|c|c|c|c|c|c|}
\hline & 235 & 235_25 & 238 & 238_25 & 206 & 206 25 & 201_235 & $2 \mathrm{~s}$ & 200 _ 238 & $2 \mathrm{~s}$ & $201 / 206$ & $2 \mathrm{~s}$ & nce (\%) & & 25 & 5 & 5_2s & 8 & 8_2s & 6 & 6_2s \\
\hline 2001 & 0.832 & 0.02 & 0.09686 & 0.00098 & 0.0625 & 0.0015 & 614 & 11 & 595.9 & 5.8 & 682 & 51 & 12.6 & 595.9 & 5.8 & 585.6 & 6.2 & 593.4 & 6 & 557 & 21 \\
\hline Z002 & 0.794 & 0.026 & 0.097 & 0.001 & 0.0596 & 0.0021 & 592 & 14 & 597.1 & 5.9 & 569 & 76 & -4.9 & 597.1 & 5.9 & 576.6 & 7.4 & 595.6 & 6.3 & 512 & 37 \\
\hline Z003 & 0.085 & 0.0068 & 0.01277 & 0.00026 & 0.0486 & 0.0037 & 82.7 & 6.4 & 81.8 & 1.7 & 130 & 150 & 37.1 & 81.8 & 1.7 & 81.7 & 1.7 & 81.8 & 1.7 & 81.9 & 1.7 \\
\hline Z004 & 0.774 & 0.025 & 0.0925 & 0.0013 & 0.0601 & 0.0018 & 581 & 14 & 570.5 & 7.6 & 609 & 69 & 6.3 & 570.5 & 7.6 & 556.1 & 9.6 & 568.2 & 8 & 498 & 34 \\
\hline Z005 & 1.699 & 0.035 & 0.1672 & 0.0026 & 0.074 & 0.0017 & 1007 & 13 & 996 & 15 & 1035 & 45 & 3.8 & 996.0 & 15.0 & 978 & 11 & 993 & 15 & 950 & 22 \\
\hline Z006 & 1.396 & 0.047 & 0.1401 & 0.0028 & 0.0729 & 0.0026 & 886 & 20 & 845 & 16 & 1001 & 69 & 15.6 & 845.0 & 16.0 & 833 & 15 & 839 & 17 & 820 & 21 \\
\hline Z007 & 4.635 & 0.097 & 0.2928 & 0.0051 & 0.1151 & 0.0014 & 1754 & 17 & 1655 & 25 & 1880 & 22 & 12.0 & 1880.0 & 22.0 & 1646 & 28 & 1634 & 28 & 1661 & 28 \\
\hline 2008 & 1.216 & 0.027 & 0.1175 & 0.0021 & 0.0758 & 0.0027 & 807 & 12 & 716 & 12 & 1075 & 70 & 33.4 & discordant & discordant & 708 & 14 & 706 & 14 & 714 & 13 \\
\hline Z009 & 0.968 & 0.032 & 0.081 & 0.0025 & 0.087 & 0.002 & 686 & 16 & 502 & 15 & 1354 & 45 & 62.9 & discordant & discordant & 487 & 15 & 484 & 15 & 502 & 15 \\
\hline Z010 & 5.9 & 0.19 & 0.2951 & 0.0085 & 0.1455 & 0.0023 & 1957 & 27 & 1665 & 42 & 2291 & 28 & 27.3 & discordant & discordant & 1623 & 44 & 1592 & 45 & 1665 & 42 \\
\hline Z011 & 0.704 & 0.039 & 0.0858 & 0.0014 & 0.0599 & 0.0034 & 539 & 23 & 530.8 & 8.2 & 570 & 120 & 6.9 & 530.8 & 8.2 & 511 & 12 & 528.3 & 8.8 & 438 & 51 \\
\hline Z012 & 0.768 & 0.03 & 0.0928 & 0.0026 & 0.0601 & 0.0015 & 577 & 17 & 572 & 15 & 597 & 54 & 4.2 & 572.0 & 15.0 & 559 & 15 & 570 & 15 & 525 & 25 \\
\hline Z013 & 1.95 & 0.12 & 0.174 & 0.0028 & 0.0818 & 0.0048 & 1090 & 41 & 1034 & 15 & 1200 & 120 & 13.8 & 1034.0 & 15.0 & 999 & 20 & 1019 & 14 & 968 & 51 \\
\hline Z014 & 0.062 & 0.01 & 0.00879 & 0.00026 & 0.0506 & 0.0078 & 60.9 & 9.5 & 56.4 & 1.6 & 200 & 290 & 71.8 & 56.4 & 1.6 & 56.1 & 2 & 56.1 & 2 & 56.4 & 1.6 \\
\hline Z015 & 12.29 & 0.21 & 0.468 & 0.0064 & 0.191 & 0.0028 & 2625 & 16 & 2474 & 28 & 2748 & 25 & 10.0 & 2748.0 & 25.0 & 2450 & 35 & 2410 & 38 & 2485 & 33 \\
\hline Z016 & 0.414 & 0.043 & 0.04151 & 0.00082 & 0.0728 & 0.0077 & 347 & 31 & 262.1 & 5.1 & 860 & 210 & 69.5 & 262.1 & 5.1 & 254.7 & 5.9 & 256.6 & 5.3 & 256.2 & 9.1 \\
\hline Z017 & 1.484 & 0.025 & 0.1515 & 0.0014 & 0.0712 & 0.0011 & 923 & 10 & 909.6 & 7.7 & 960 & 30 & 5.3 & 909.6 & 7.7 & 901.8 & 7.9 & 907.1 & 8 & 893 & 13 \\
\hline Z019 & 1.718 & 0.031 & 0.1675 & 0.002 & 0.0744 & 0.0014 & 1014 & 12 & 998 & 11 & 1046 & 40 & 4.6 & 998.0 & 11.0 & 987 & 12 & 995 & 12 & 963 & 23 \\
\hline Z020 & 0.092 & 0.011 & 0.01272 & 0.00041 & 0.0531 & 0.007 & 89 & 11 & 81.4 & 2.6 & 250 & 250 & 67.4 & 81.4 & 2.6 & 80.9 & 2.8 & 81 & 2.8 & 81.1 & 2.7 \\
\hline Z021 & 0.812 & 0.062 & 0.1011 & 0.0021 & 0.059 & 0.0049 & 613 & 42 & 621 & 13 & 520 & 180 & -19.4 & discordant & discordant & 606 & 17 & 621 & 15 & 552 & 43 \\
\hline Z022 & 0.0642 & 0.0045 & 0.01004 & 0.00021 & 0.0464 & 0.0031 & 63.1 & 4.3 & 64.4 & 1.3 & 40 & 120 & -61.0 & 64.4 & 1.3 & 64.1 & 1.2 & 64.2 & 1.2 & 64.5 & 1.3 \\
\hline Z023 & 0.0704 & 0.0099 & 0.0109 & 0.0003 & 0.0473 & 0.0069 & 68.6 & 9.3 & 69.9 & 1.9 & 30 & 250 & -133.0 & 69.9 & 1.9 & 69.9 & 2.1 & 70 & 2.1 & 69.9 & 1.9 \\
\hline Z024 & 0.615 & 0.024 & 0.0752 & 0.0022 & 0.0595 & 0.002 & 485 & 15 & 467 & 13 & 569 & 73 & 17.9 & 467.0 & 13.0 & 453 & 12 & 465 & 13 & 401 & 30 \\
\hline Z026 & 0.095 & 0.021 & 0.00984 & 0.00032 & 0.069 & 0.014 & 91 & 18 & 63.1 & 2 & 620 & 360 & 89.8 & 63.1 & 2.0 & 61.5 & 2.4 & 61.6 & 2.4 & 63.5 & 2.4 \\
\hline $\mathrm{Z} 2027$ & 0.779 & 0.026 & 0.09496 & 0.00088 & 0.0597 & 0.0019 & 584 & 15 & 584.8 & 5.2 & 573 & 73 & -2.1 & 584.8 & 5.2 & 562.4 & 9.5 & 582.8 & 5.2 & 479 & 50 \\
\hline Z028 & 0.743 & 0.022 & 0.0922 & 0.001 & 0.0586 & 0.0017 & 563 & 13 & 568.7 & 6.2 & 538 & 64 & -5.7 & discordant & discordant & 548.2 & 8.8 & 567.3 & 6.3 & 469 & 43 \\
\hline Z029 & 0.061 & 0.0083 & 0.00893 & 0.00023 & 0.0498 & 0.0069 & 59.8 & 7.9 & 57.3 & 1.5 & 120 & 250 & 52.3 & 57.3 & 1.5 & 57.1 & 1.6 & 57.1 & 1.6 & 57.3 & 1.5 \\
\hline Z030 & 0.811 & 0.025 & 0.097 & 0.0014 & 0.0608 & 0.0017 & 602 & 14 & 596.8 & 8.2 & 620 & 62 & 3.7 & 596.8 & 8.2 & 579.7 & 9.2 & 594.8 & 8.3 & 530 & 32 \\
\hline Z031 & 0.1011 & 0.0087 & 0.01642 & 0.00035 & 0.0448 & 0.004 & 97.4 & 8 & 105 & 2.2 & -20 & 160 & 625.0 & 105.0 & 2.2 & 105.3 & 2.5 & 105.4 & 2.5 & 104.3 & 3 \\
\hline Z032 & 0.0663 & 0.0079 & 0.01048 & 0.00032 & 0.0458 & 0.005 & 65 & 7.4 & 67.2 & 2 & 0 & 190 & \#DIV/0! & 67.2 & 2.0 & 67.3 & 2 & 67.4 & 2 & 67.3 & 2 \\
\hline Z033 & 0.602 & 0.02 & 0.076 & 0.0012 & 0.0576 & 0.0021 & 477 & 13 & 472.4 & 7.5 & 496 & 80 & 4.8 & 472.4 & 7.5 & 462.2 & 9.1 & 471.2 & 8 & 433 & 24 \\
\hline Z035 & 0.0651 & 0.0088 & 0.00974 & 0.00023 & 0.0486 & 0.0067 & 63.7 & 8.4 & 62.5 & 1.4 & 90 & 240 & 30.6 & 62.5 & 1.4 & 62.4 & 1.5 & 62.4 & 1.6 & 62.5 & 1.4 \\
\hline Z036 & 0.619 & 0.02 & 0.0788 & 0.00087 & 0.057 & 0.0018 & 489 & 13 & 488.9 & 5.2 & 474 & 71 & -3.1 & 488.9 & 5.2 & 476.8 & 6.6 & 487.8 & 5.2 & 433 & 28 \\
\hline Z038 & 0.663 & 0.022 & 0.0829 & 0.0015 & 0.0584 & 0.0022 & 516 & 13 & 513.1 & 9.2 & 524 & 80 & 2.1 & 513.1 & 9.2 & 499 & 10 & 511.7 & 9.8 & 440 & 33 \\
\hline Z039 & 2.184 & 0.063 & 0.1918 & 0.0036 & 0.0831 & 0.0027 & 1174 & 20 & 1131 & 20 & 1260 & 64 & 10.2 & 1131.0 & 20.0 & 1114 & 16 & 1122 & 22 & 1090 & 26 \\
\hline Z040 & 0.1054 & 0.007 & 0.01549 & 0.00039 & 0.0509 & 0.0042 & 101.5 & 6.4 & 99.1 & 2.5 & 190 & 150 & 47.8 & 99.1 & 2.5 & 98.6 & 2.8 & 98.8 & 2.8 & 97.6 & 3.3 \\
\hline Z041 & 1.716 & 0.04 & 0.167 & 0.0019 & 0.0748 & 0.002 & 1013 & 15 & 995 & 11 & 1053 & 54 & 5.5 & 995.0 & 11.0 & 975 & 11 & 991 & 12 & 941 & 27 \\
\hline Z042 & 3.67 & 0.18 & 0.2585 & 0.007 & 0.102 & 0.0029 & 1557 & 37 & 1481 & 36 & 1663 & 55 & 10.9 & 1663.0 & 55.0 & 1470 & 37 & 1466 & 37 & 1477 & 37 \\
\hline Z043 & 0.752 & 0.057 & 0.0903 & 0.0019 & 0.0608 & 0.0048 & 564 & 34 & 557 & 11 & 560 & 170 & 0.5 & 557.0 & 11.0 & 537 & 13 & 554 & 12 & 462 & 48 \\
\hline Z044 & 2.156 & 0.054 & 0.1927 & 0.0023 & 0.0814 & 0.0021 & 1165 & 17 & 1136 & 12 & 1221 & 51 & 7.0 & 1136.0 & 12.0 & 1120 & 14 & 1130 & 13 & 1102 & 23 \\
\hline Z045 & 0.095 & 0.013 & 0.01425 & 0.00046 & 0.0492 & 0.0069 & 91 & 12 & 91.2 & 2.9 & 100 & 250 & 8.8 & 91.2 & 2.9 & 91.2 & 3.3 & 91.2 & 3.3 & 91.2 & 2.9 \\
\hline Z046 & 1.368 & 0.048 & 0.1398 & 0.0032 & 0.0707 & 0.0018 & 873 & 21 & 843 & 18 & 950 & 57 & 11.3 & 843.0 & 18.0 & 830 & 18 & 838 & 19 & 810 & 24 \\
\hline Z047 & 0.273 & 0.012 & 0.03634 & 0.00058 & 0.0547 & 0.0025 & 244.5 & 9.3 & 230.1 & 3.6 & 375 & 98 & 38.6 & 230.1 & 3.6 & 227.2 & 4.3 & 228.9 & 3.9 & 218 & 11 \\
\hline Z048 & 1.729 & 0.075 & 0.1703 & 0.0027 & 0.0739 & 0.0032 & 1015 & 28 & 1013 & 15 & 1010 & 90 & -0.3 & 1013.0 & 15.0 & 971 & 19 & 1008 & 16 & 913 & 42 \\
\hline Z049 & 0.0669 & 0.0056 & 0.01001 & 0.00031 & 0.049 & 0.0044 & 65.6 & 5.3 & 64.2 & 2 & 170 & 180 & 62.2 & 64.2 & 2.0 & 63.9 & 2.1 & 64 & 2.1 & 63.7 & 2.1 \\
\hline Z050 & 0.077 & 0.012 & 0.01048 & 0.0004 & 0.0542 & 0.0093 & 75 & 12 & 67.2 & 2.6 & 290 & 330 & 76.8 & 67.2 & 2.6 & 66.7 & 3.1 & 66.7 & 3.1 & 67.2 & 2.6 \\
\hline Z051 & 0.889 & 0.054 & 0.1008 & 0.0024 & 0.0642 & 0.003 & 642 & 26 & 619 & 14 & 724 & 80 & 14.5 & 619.0 & 14.0 & 612 & 13 & 615 & 12 & 606 & 21 \\
\hline
\end{tabular}




\begin{tabular}{|c|c|c|c|c|c|c|c|c|c|c|c|c|c|c|c|c|c|c|c|c|c|}
\hline Z052 & 1.732 & 0.072 & 0.1684 & 0.0057 & 0.0753 & 0.0029 & 1018 & 27 & 1003 & 31 & 1063 & 79 & 5.6 & 1003.0 & 31.0 & 974 & 26 & 998 & 33 & 944 & 36 \\
\hline 2053 & 0.119 & 0.012 & 0.01821 & 0.00043 & 0.0464 & 0.0047 & 113 & 11 & 116.3 & 2.7 & 60 & 190 & -93.8 & 116.3 & 2.7 & 116.1 & 3 & 116.5 & 3 & 114.1 & 4.7 \\
\hline 2054 & 0.728 & 0.02 & 0.09131 & 0.0009 & 0.0585 & 0.002 & 554 & 12 & 563.2 & 5.3 & 530 & 75 & -6.3 & discordant & discordant & 542.9 & 8.3 & 561.9 & 5.6 & 461 & 45 \\
\hline 2055 & 10.35 & 0.2 & 0.4579 & 0.0074 & 0.1637 & 0.002 & 2465 & 17 & 2429 & 33 & 2493 & 20 & 2.6 & 2493.0 & 20.0 & 2413 & 28 & 2412 & 37 & 2417 & 24 \\
\hline Z056 & 0.0539 & 0.0091 & 0.00861 & 0.00027 & 0.0451 & 0.0072 & 52.8 & 8.8 & 55.3 & 1.7 & -40 & 260 & 238.3 & 55.3 & 1.7 & 55.4 & 1.7 & 55.4 & 1.7 & 55.3 & 1.8 \\
\hline Z057 & 0.101 & 0.02 & 0.01068 & 0.00043 & 0.069 & 0.013 & 96 & 18 & 68.5 & 2.7 & 630 & 380 & 89.1 & 68.5 & 2.7 & 66.2 & 3.1 & 66.2 & 3.1 & 68.2 & 2.8 \\
\hline Z058 & 0.075 & 0.011 & 0.0083 & 0.00015 & 0.0652 & 0.0085 & 73 & 10 & 53.32 & 0.96 & 600 & 240 & 91.1 & 53.3 & 1.0 & 52.06 & 0.91 & 52.03 & 0.91 & 53.32 & 0.96 \\
\hline Z059 & 0.079 & 0.011 & 0.01022 & 0.00023 & 0.0558 & 0.0072 & 76 & 10 & 65.5 & 1.5 & 370 & 240 & 82.3 & 65.5 & 1.5 & 64.7 & 1.5 & 64.6 & 1.5 & 65.2 & 1.6 \\
\hline $\mathrm{Z} 060$ & 0.776 & 0.025 & 0.0938 & 0.0012 & 0.0601 & 0.002 & 582 & 14 & 578.2 & 7 & 591 & 70 & 2.2 & 578.2 & 7.0 & 558.7 & 6.4 & 576.2 & 7.3 & 499 & 33 \\
\hline $\mathrm{Z} 061$ & 0.0699 & 0.009 & 0.00735 & 0.00016 & 0.0717 & 0.0096 & 68.2 & 8.4 & 47.2 & 1 & 770 & 260 & 93.9 & 47.2 & 1.0 & 45.8 & 1.2 & 45.7 & 1.2 & 47.2 & 1 \\
\hline Z062 & 0.2686 & 0.0085 & 0.03841 & 0.00043 & 0.0508 & 0.0016 & 241.3 & 6.8 & 242.9 & 2.7 & 224 & 69 & -8.4 & 242.9 & 2.7 & 240.2 & 3.4 & 242.8 & 2.8 & 215 & 17 \\
\hline Z064 & 11.02 & 0.18 & 0.4807 & 0.0069 & 0.1668 & 0.0031 & 2524 & 15 & 2530 & 30 & 2522 & 31 & -0.3 & 2522.0 & 31.0 & 2492 & 24 & 2519 & 36 & 2474 & 27 \\
\hline Z065 & 0.085 & 0.012 & 0.00991 & 0.00038 & 0.0611 & 0.0072 & 82 & 11 & 63.6 & 2.4 & 480 & 210 & 86.8 & 63.6 & 2.4 & 62.3 & 2.2 & 62.3 & 2.2 & 62 & 2.9 \\
\hline Z067 & 0.0538 & 0.0048 & 0.00762 & 0.00015 & 0.0516 & 0.0048 & 53.1 & 4.6 & 48.93 & 0.94 & 220 & 170 & 77.8 & 48.9 & 0.9 & 48.6 & 1.1 & 48.7 & 1.1 & 49.13 & 0.92 \\
\hline Z068 & 0.0427 & 0.0023 & 0.00636 & 0.00011 & 0.0488 & 0.0026 & 42.4 & 2.2 & 40.84 & 0.68 & 140 & 110 & 70.8 & 40.8 & 0.7 & 40.75 & 0.72 & 40.74 & 0.72 & 40.75 & 0.71 \\
\hline Z069 & 2.266 & 0.081 & 0.1986 & 0.0038 & 0.0832 & 0.0031 & 1198 & 25 & 1167 & 21 & 1253 & 76 & 6.9 & 1167.0 & 21.0 & 1133 & 20 & 1158 & 22 & 1100 & 36 \\
\hline Z070 & 1.413 & 0.049 & 0.1426 & 0.0029 & 0.072 & 0.0023 & 892 & 20 & 859 & 16 & 973 & 63 & 11.7 & 859.0 & 16.0 & 842 & 15 & 854 & 17 & 811 & 22 \\
\hline Z071 & 0.1216 & 0.0078 & 0.0174 & 0.0011 & 0.0508 & 0.0016 & 116.2 & 7.2 & 111.4 & 7.1 & 223 & 67 & 50.0 & 111.4 & 7.1 & 110.7 & 7.1 & 111 & 7.1 & 105.3 & 8.1 \\
\hline Z074 & 1.865 & 0.046 & 0.1763 & 0.0019 & 0.0769 & 0.002 & 1067 & 16 & 1047 & 10 & 1108 & 52 & 5.5 & 1047.0 & 10.0 & 1028 & 12 & 1042 & 11 & 1004 & 25 \\
\hline Z075 & 1.522 & 0.067 & 0.1542 & 0.006 & 0.0717 & 0.0016 & 935 & 27 & 924 & 33 & 969 & 45 & 4.6 & 924.0 & 33.0 & 905 & 29 & 920 & 34 & 875 & 28 \\
\hline Z076 & 0.256 & 0.013 & 0.03687 & 0.00056 & 0.0504 & 0.0025 & 231 & 10 & 233.4 & 3.5 & 230 & 110 & -1.5 & 233.4 & 3.5 & 230.6 & 3.9 & 233.1 & 3.6 & 204 & 19 \\
\hline Z078 & 1.27 & 0.14 & 0.1092 & 0.0037 & 0.0855 & 0.0098 & 814 & 59 & 668 & 22 & 1170 & 200 & 42.9 & discordant & discordant & 644 & 23 & 649 & 25 & 633 & 29 \\
\hline Z079 & 0.764 & 0.032 & 0.0795 & 0.0027 & 0.0719 & 0.0035 & 576 & 19 & 493 & 16 & 966 & 94 & 49.0 & 493.0 & 16.0 & 486 & 16 & 484 & 16 & 493 & 16 \\
\hline Z080 & 4.68 & 0.17 & 0.3075 & 0.0043 & 0.1101 & 0.0034 & 1759 & 29 & 1728 & 21 & 1789 & 55 & 3.4 & 1789.0 & 55.0 & 1703 & 21 & 1717 & 22 & 1692 & 34 \\
\hline Z081 & 0.038 & 0.0046 & 0.00557 & 0.00014 & 0.0489 & 0.0054 & 37.8 & 4.5 & 35.78 & 0.89 & 150 & 220 & 76.1 & 35.8 & 0.9 & 35.67 & 0.86 & 35.7 & 0.87 & 36.1 & 1.1 \\
\hline Z082 & 2.17 & 0.14 & 0.1894 & 0.0037 & 0.0828 & 0.0051 & 1160 & 44 & 1118 & 20 & 1280 & 120 & 12.7 & 1118.0 & 20.0 & 1087 & 20 & 1111 & 24 & 1069 & 34 \\
\hline Z083 & 3.84 & 0.12 & 0.2656 & 0.0049 & 0.1057 & 0.0029 & 1597 & 26 & 1518 & 25 & 1718 & 50 & 11.6 & 1718.0 & 50.0 & 1503 & 25 & 1499 & 26 & 1509 & 26 \\
\hline Z084 & 0.1329 & 0.0044 & 0.01967 & 0.00052 & 0.0488 & 0.0013 & 126.6 & 3.9 & 125.5 & 3.3 & 152 & 60 & 17.4 & 125.5 & 3.3 & 125.2 & 3.3 & 125.5 & 3.4 & 122.5 & 4.3 \\
\hline 2085 & 0.093 & 0.011 & 0.01355 & 0.00027 & 0.05 & 0.0059 & 90 & 10 & 86.8 & 1.7 & 150 & 210 & 42.1 & 86.8 & 1.7 & 86.4 & 1.8 & 86.5 & 1.9 & 85.8 & 2.1 \\
\hline Z086 & 0.834 & 0.038 & 0.1 & 0.001 & 0.0608 & 0.0028 & 613 & 21 & 614.2 & 6.1 & 600 & 97 & -2.4 & 614.2 & 6.1 & 585 & 11 & 611.5 & 6.6 & 489 & 49 \\
\hline Z087 & 9.93 & 0.19 & 0.3925 & 0.0059 & 0.1836 & 0.0022 & 2426 & 18 & 2134 & 27 & 2684 & 20 & 20.5 & discordant & discordant & 2080 & 29 & 2027 & 31 & 2134 & 27 \\
\hline Z088 & 12.79 & 0.28 & 0.4964 & 0.0063 & 0.1871 & 0.0041 & 2662 & 20 & 2598 & 27 & 2712 & 36 & 4.2 & 2712.0 & 36.0 & 2575 & 27 & 2564 & 35 & 2586 & 26 \\
\hline Z089 & 0.726 & 0.026 & 0.0839 & 0.0019 & 0.0623 & 0.0015 & 553 & 15 & 520 & 11 & 674 & 50 & 22.8 & discordant & discordant & 514 & 11 & 516 & 11 & 510 & 14 \\
\hline 2090 & 0.252 & 0.014 & 0.03316 & 0.00058 & 0.0555 & 0.0033 & 228 & 11 & 210.3 & 3.6 & 390 & 130 & 46.1 & 210.3 & 3.6 & 208 & 4 & 208.9 & 4.1 & 206.2 & 6 \\
\hline Z091 & 0.0521 & 0.006 & 0.00799 & 0.0002 & 0.0464 & 0.0052 & 51.4 & 5.7 & 51.3 & 1.3 & 50 & 200 & -2.6 & 51.3 & 1.3 & 51.2 & 1.4 & 51.3 & 1.4 & 51.1 & 1.2 \\
\hline Z093 & 0.091 & 0.013 & 0.01322 & 0.00043 & 0.0508 & 0.0078 & 88 & 12 & 84.7 & 2.7 & 140 & 260 & 39.5 & 84.7 & 2.7 & 84.3 & 3 & 84.4 & 3.1 & 83.1 & 3.5 \\
\hline Z094 & 0.629 & 0.034 & 0.0781 & 0.0023 & 0.0582 & 0.0021 & 493 & 21 & 485 & 14 & 515 & 79 & 5.8 & 485.0 & 14.0 & 472 & 14 & 483 & 13 & 421 & 32 \\
\hline Z095 & 0.739 & 0.048 & 0.0916 & 0.0018 & 0.0577 & 0.0034 & 558 & 27 & 565 & 10 & 500 & 130 & -13.0 & discordant & discordant & 544 & 12 & 563 & 11 & 460 & 49 \\
\hline 2096 & 0.0554 & 0.0088 & 0.00754 & 0.00035 & 0.0527 & 0.0054 & 54.4 & 8 & 48.4 & 2.3 & 250 & 150 & 80.6 & 48.4 & 2.3 & 47.8 & 1.9 & 47.8 & 1.9 & 47.9 & 2.5 \\
\hline Zo97 & 0.099 & 0.013 & 0.01448 & 0.00043 & 0.0503 & 0.0068 & 95 & 12 & 92.7 & 2.7 & 140 & 240 & 33.8 & 92.7 & 2.7 & 92.4 & 3 & 92.4 & 3 & 92.7 & 2.8 \\
\hline Z098 & 1.728 & 0.086 & 0.1743 & 0.0031 & 0.0723 & 0.0039 & 1013 & 33 & 1036 & 17 & 950 & 120 & -9.1 & discordant & discordant & 979 & 22 & 1031 & 18 & 858 & 77 \\
\hline Z099 & 0.676 & 0.018 & 0.0849 & 0.001 & 0.0578 & 0.0016 & 523 & 11 & 525.1 & 6.2 & 510 & 63 & -3.0 & 525.1 & 6.2 & 510.1 & 7.6 & 524 & 6.5 & 458 & 29 \\
\hline $\mathrm{Z100}$ & 0.0895 & 0.0053 & 0.01339 & 0.00023 & 0.0487 & 0.0031 & 86.9 & 5 & 85.7 & 1.4 & 130 & 120 & 34.1 & 85.7 & 1.4 & 85.3 & 1.6 & 85.6 & 1.6 & 80.8 & 4.4 \\
\hline Z101 & 0.051 & 0.0039 & 0.00783 & 0.00019 & 0.0475 & 0.0036 & 50.5 & 3.8 & 50.3 & 1.2 & 80 & 140 & 37.1 & 50.3 & 1.2 & 50.2 & 1.3 & 50.2 & 1.3 & 50.3 & 1.2 \\
\hline $\mathrm{Z102}$ & 0.0394 & 0.0061 & 0.00584 & 0.0002 & 0.0498 & 0.0083 & 39 & 6 & 37.5 & 1.3 & 100 & 290 & 62.5 & 37.5 & 1.3 & 37.4 & 1.4 & 37.4 & 1.4 & 37.4 & 1.3 \\
\hline Z103 & 0.952 & 0.041 & 0.1082 & 0.0012 & 0.0638 & 0.0026 & 677 & 21 & 662.4 & 7.1 & 711 & 86 & 6.8 & 662.4 & 7.1 & 638.2 & 9.8 & 658.6 & 7.3 & 567 & 42 \\
\hline Z104 & 5.03 & 0.22 & 0.334 & 0.011 & 0.11 & 0.0031 & 1818 & 36 & 1855 & 55 & 1792 & 51 & -3.5 & 1792.0 & 51.0 & 1790 & 40 & 1849 & 56 & 1734 & 42 \\
\hline Z106 & 1.856 & 0.075 & 0.1813 & 0.0032 & 0.0745 & 0.0032 & 1062 & 27 & 1074 & 18 & 1027 & 89 & -4.6 & 1074.0 & 18.0 & 1023 & 20 & 1069 & 19 & 943 & 49 \\
\hline Z107 & 0.745 & 0.086 & 0.094 & 0.0031 & 0.0581 & 0.0067 & 557 & 52 & 579 & 18 & 470 & 250 & -23.2 & discordant & discordant & 577 & 21 & 580 & 20 & 565 & 27 \\
\hline Z108 & 0.697 & 0.033 & 0.0878 & 0.0015 & 0.0576 & 0.0025 & 535 & 19 & 542.7 & 9.1 & 486 & 92 & -11.7 & discordant & discordant & 515 & 11 & 541 & 9.1 & 399 & 51 \\
\hline Z109 & 2.687 & 0.048 & 0.2304 & 0.0029 & 0.0852 & 0.002 & 1327 & 14 & 1336 & 15 & 1312 & 46 & -1.8 & 1312.0 & 46.0 & 1305 & 14 & 1333 & 16 & 1260 & 31 \\
\hline $\mathrm{Z110}$ & 1.16 & 0.061 & 0.1224 & 0.004 & 0.0687 & 0.0028 & 777 & 28 & 744 & 23 & 865 & 82 & 14.0 & 744.0 & 23.0 & 727 & 24 & 739 & 23 & 696 & 32 \\
\hline
\end{tabular}




\begin{tabular}{|c|c|c|c|c|c|c|c|c|c|c|c|c|c|c|c|c|c|c|c|}
\hline 0.882 & 0.016 & 0.10654 & 0.00093 & 0.0599 & 0.0012 & 641.5 & 8.8 & 652.6 & 5.4 & 594 & 43 & -9.9 & discordant & discordant & 633.1 & 7.2 & 651.8 & 5.6 & 567 \\
\hline 0.0482 & 0.0059 & 0.00735 & 0.00018 & 0.0464 & 0.0054 & 47.6 & 5.7 & 47.2 & 1.2 & 60 & 220 & 21.3 & 47.2 & 1.2 & 47.2 & 1.3 & 47.2 & 1.3 & 47.2 \\
\hline 0.0531 & 0.0053 & 0.00791 & 0.00019 & 0.0492 & 0.0052 & 52.4 & 5.1 & 50.8 & 1.2 & 130 & 190 & 60.9 & 50.8 & 1.2 & 50.7 & 1.4 & 50.7 & 1.4 & 50.8 \\
\hline 0.0624 & 0.006 & 0.00938 & 0.00035 & 0.0484 & 0.0043 & 61.3 & 5.7 & 60.2 & 2.3 & 120 & 170 & 49.8 & 60.2 & 2.3 & 60.1 & 2.3 & 60.1 & 2.3 & 60.3 \\
\hline 0.796 & 0.02 & 0.0971 & 0.0011 & 0.0595 & 0.0016 & 594 & 11 & 597.6 & 6.5 & 574 & 57 & -4.1 & 597.6 & 6.5 & 577.3 & 7 & 596.2 & 6.8 & 505 \\
\hline 1.49 & 0.12 & 0.1484 & 0.0051 & 0.0731 & 0.0054 & 914 & 47 & 891 & 29 & 940 & 150 & 5.2 & 891.0 & 29.0 & 848 & 30 & 883 & 30 & 770 \\
\hline 0.605 & 0.016 & 0.0773 & 0.00098 & 0.0569 & 0.0017 & 480 & 10 & 480 & 5.9 & 473 & 66 & -1.5 & 480.0 & 5.9 & 464.9 & 5.9 & 478.8 & 6.2 & 397 \\
\hline 0.0489 & 0.0072 & 0.00727 & 0.00026 & 0.0488 & 0.0074 & 48.2 & 7 & 46.7 & 1.7 & 100 & 270 & 53.3 & 46.7 & 1.7 & 46.6 & 1.8 & 46.6 & 1.8 & 46.7 \\
\hline 0.251 & 0.011 & 0.03645 & 0.00073 & 0.0502 & 0.0022 & 227.3 & 8.7 & 230.8 & 4.6 & 196 & 90 & -17.8 & 230.8 & 4.6 & 228.1 & 4.6 & 230.8 & 4.8 & 200 \\
\hline
\end{tabular}




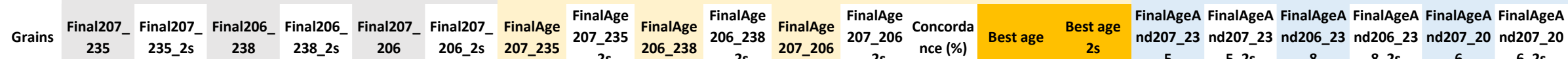

\begin{tabular}{|c|c|c|c|c|c|c|c|c|c|c|c|c|c|c|c|c|c|c|c|c|c|}
\hline & & & & & & & & $2 \mathrm{~s}$ & & $2 \mathrm{~s}$ & & $2 \mathrm{~s}$ & & & & 5 & $5 \_2 \mathrm{~s}$ & 8 & 8_2s & 6 & 6_2s \\
\hline Z001 & 0.1544 & 0.0077 & 0.02247 & 0.00036 & 0.05 & 0.0027 & 145.5 & 6.8 & 143.2 & 2.3 & 190 & 110 & 24.6 & 143.2 & 2.3 & 142.8 & 2.4 & 143.1 & 2.5 & 141.3 & 3 \\
\hline Z002 & 0.21 & 0.03 & 0.0286 & 0.0012 & 0.0539 & 0.0083 & 190 & 25 & 181.6 & 7.4 & 290 & 290 & 37.4 & 181.6 & 7.4 & 180.6 & 8.1 & 180.9 & 8.1 & 179.5 & 8.4 \\
\hline Z003 & 0.091 & 0.019 & 0.00829 & 0.00023 & 0.079 & 0.015 & 87 & 16 & 53.2 & 1.5 & 980 & 350 & 94.6 & 53.2 & 1.5 & 51.3 & 1.4 & 51.2 & 1.4 & 52.9 & 1.7 \\
\hline Zo04 & 0.0511 & 0.0032 & 0.00797 & 0.00014 & 0.0466 & 0.003 & 50.5 & 3.1 & 51.15 & 0.89 & 70 & 130 & 26.9 & 51.2 & 0.9 & 51.06 & 0.94 & 51.12 & 0.97 & 50.81 & 0.89 \\
\hline Z005 & 0.084 & 0.011 & 0.01055 & 0.00028 & 0.0577 & 0.0071 & 82 & 10 & 67.6 & 1.8 & 450 & 240 & 85.0 & 67.6 & 1.8 & 66.5 & 1.8 & 66.5 & 1.8 & 67.3 & 2 \\
\hline Z006 & 0.0549 & 0.0099 & 0.00725 & 0.00015 & 0.0563 & 0.0095 & 54 & 9.2 & 46.57 & 0.95 & 420 & 310 & 88.9 & 46.6 & 1.0 & 45.8 & 1.1 & 45.8 & 1.1 & 46.63 & 0.98 \\
\hline zoo7 & 0.067 & 0.011 & 0.00791 & 0.00032 & 0.0617 & 0.0099 & 68 & 11 & 50.8 & 2 & 520 & 310 & 90.2 & 50.8 & 2.0 & 49.1 & 2.5 & 49.1 & 2.5 & 50.3 & 2.3 \\
\hline Z008 & 0.775 & 0.033 & 0.0929 & 0.0012 & 0.0606 & 0.0025 & 581 & 19 & 572.6 & 6.9 & 598 & 90 & 4.2 & 572.6 & 6.9 & 553.3 & 9.7 & 570.1 & 7.3 & 490 & 41 \\
\hline 2009 & 0.094 & 0.011 & 0.01344 & 0.00035 & 0.0518 & 0.0067 & 91 & 10 & 86 & 2.2 & 190 & 230 & 54.7 & 86.0 & 2.2 & 85.5 & 2.5 & 85.7 & 2.5 & 85.3 & 2.3 \\
\hline 2010 & 0.107 & 0.0096 & 0.0159 & 0.00053 & 0.049 & 0.0043 & 102.8 & 8.8 & 101.7 & 3.4 & 130 & 160 & 21.8 & 101.7 & 3.4 & 101.5 & 3.4 & 101.6 & 3.5 & 101 & 3.2 \\
\hline Z011 & 0.056 & 0.01 & 0.00832 & 0.00026 & 0.0499 & 0.0092 & 55.3 & 9.5 & 53.4 & 1.6 & 70 & 290 & 23.7 & 53.4 & 1.6 & 53.3 & 1.8 & 53.3 & 1.9 & 53.4 & 1.6 \\
\hline Z012 & 0.148 & 0.012 & 0.01681 & 0.00036 & 0.0637 & 0.0045 & 140 & 10 & 107.5 & 2.3 & 660 & 140 & 83.7 & 107.5 & 2.3 & 105.3 & 2.3 & 105.3 & 2.2 & 107.5 & 2.4 \\
\hline Z013 & 0.1653 & 0.0042 & 0.02393 & 0.00021 & 0.0501 & 0.0013 & 155.3 & 3.7 & 152.4 & 1.3 & 197 & 55 & 22.6 & 152.4 & 1.3 & 152 & 1.4 & 152.2 & 1.4 & 150.3 & 3 \\
\hline Z014 & 0.066 & 0.0086 & 0.01073 & 0.00029 & 0.0435 & 0.0054 & 64.5 & 8.1 & 68.8 & 1.9 & -50 & 220 & 237.6 & 68.8 & 1.9 & 69.1 & 2 & 69 & 2 & 68.5 & 2 \\
\hline Z015 & 0.065 & 0.014 & 0.00962 & 0.0005 & 0.049 & 0.01 & 63 & 13 & 61.7 & 3.2 & 30 & 340 & -105.7 & 61.7 & 3.2 & 61.5 & 3.3 & 61.6 & 3.3 & 61.6 & 3.2 \\
\hline Z016 & 11.85 & 0.17 & 0.4783 & 0.0055 & 0.1798 & 0.0018 & 2595 & 12 & 2519 & 24 & 2650 & 17 & 4.9 & 2650.0 & 17.0 & 2526 & 30 & 2496 & 31 & 2548 & 31 \\
\hline Z017 & 0.647 & 0.04 & 0.083 & 0.0017 & 0.0576 & 0.0035 & 504 & 24 & 514 & 10 & 480 & 130 & -7.1 & discordant & discordant & 495 & 13 & 513 & 11 & 428 & 46 \\
\hline Z018 & 0.737 & 0.017 & 0.09116 & 0.00097 & 0.0587 & 0.0011 & 560 & 10 & 562.4 & 5.7 & 551 & 42 & -2.1 & 562.4 & 5.7 & 549.1 & 8 & 561.4 & 5.9 & 509 & 23 \\
\hline Z019 & 0.648 & 0.029 & 0.0818 & 0.0011 & 0.0575 & 0.0024 & 506 & 18 & 506.9 & 6.5 & 484 & 85 & -4.7 & 506.9 & 6.5 & 489.2 & 8.7 & 505.5 & 6.2 & 403 & 37 \\
\hline $\mathrm{ZO20}$ & 0.103 & 0.011 & 0.01532 & 0.00042 & 0.0488 & 0.0048 & 99 & 10 & 98 & 2.7 & 160 & 200 & 38.8 & 98.0 & 2.7 & 97.7 & 2.7 & 97.7 & 2.7 & 98.4 & 2.6 \\
\hline $\mathrm{ZO21}$ & 0.248 & 0.021 & 0.03521 & 0.00084 & 0.0511 & 0.0043 & 223 & 17 & 223.1 & 5.2 & 200 & 160 & -11.6 & 223.1 & 5.2 & 219.5 & 4.6 & 222.7 & 5.3 & 192 & 20 \\
\hline Z022 & 0.263 & 0.018 & 0.03836 & 0.00054 & 0.0501 & 0.0034 & 236 & 14 & 242.7 & 3.3 & 180 & 130 & -34.8 & 242.7 & 3.3 & 240.3 & 3.3 & 242.9 & 3.6 & 225 & 12 \\
\hline Z024 & 0.107 & 0.017 & 0.01427 & 0.00042 & 0.0527 & 0.008 & 102 & 15 & 92 & 3 & 270 & 280 & 65.9 & 92.0 & 3.0 & 90.4 & 3.1 & 90.4 & 3.2 & 92 & 3 \\
\hline Z025 & 1.727 & 0.042 & 0.1732 & 0.002 & 0.0723 & 0.0016 & 1017 & 15 & 1030 & 11 & 988 & 47 & -4.3 & 1030.0 & 11.0 & 1004 & 12 & 1028 & 11 & 951 & 30 \\
\hline Z026 & 0.0437 & 0.0046 & 0.00692 & 0.00019 & 0.0452 & 0.0048 & 43.3 & 4.5 & 44.4 & 1.2 & 20 & 190 & -122.0 & 44.4 & 1.2 & 44.4 & 1.4 & 44.5 & 1.4 & 44 & 1.5 \\
\hline Z027 & 2.23 & 0.075 & 0.2036 & 0.0026 & 0.0794 & 0.0024 & 1188 & 24 & 1195 & 14 & 1170 & 60 & -2.1 & 1195.0 & 14.0 & 1155 & 17 & 1190 & 15 & 1107 & 34 \\
\hline Z028 & 0.1 & 0.041 & 0.00775 & 0.00062 & 0.087 & 0.028 & 93 & 36 & 49.8 & 4 & 910 & 540 & 94.5 & 49.8 & 4.0 & 46.9 & 2.5 & 46.8 & 2.5 & 49.8 & 4 \\
\hline Z029 & 0.0608 & 0.0059 & 0.00847 & 0.00016 & 0.0522 & 0.005 & 59.8 & 5.6 & 54.4 & 1 & 250 & 190 & 78.2 & 54.4 & 1.0 & 54 & 1.2 & 54 & 1.1 & 54 & 1.5 \\
\hline Z030 & 0.0578 & 0.0034 & 0.00963 & 0.00025 & 0.0442 & 0.0024 & 57 & 3.2 & 61.8 & 1.6 & -50 & 100 & 223.6 & 61.8 & 1.6 & 61.8 & 1.8 & 62 & 1.7 & 61.4 & 2.3 \\
\hline Z031 & 0.144 & 0.024 & 0.01447 & 0.00043 & 0.071 & 0.01 & 135 & 20 & 92.6 & 2.8 & 810 & 260 & 88.6 & 92.6 & 2.8 & 90.1 & 3 & 89.9 & 3 & 92.6 & 2.8 \\
\hline
\end{tabular}




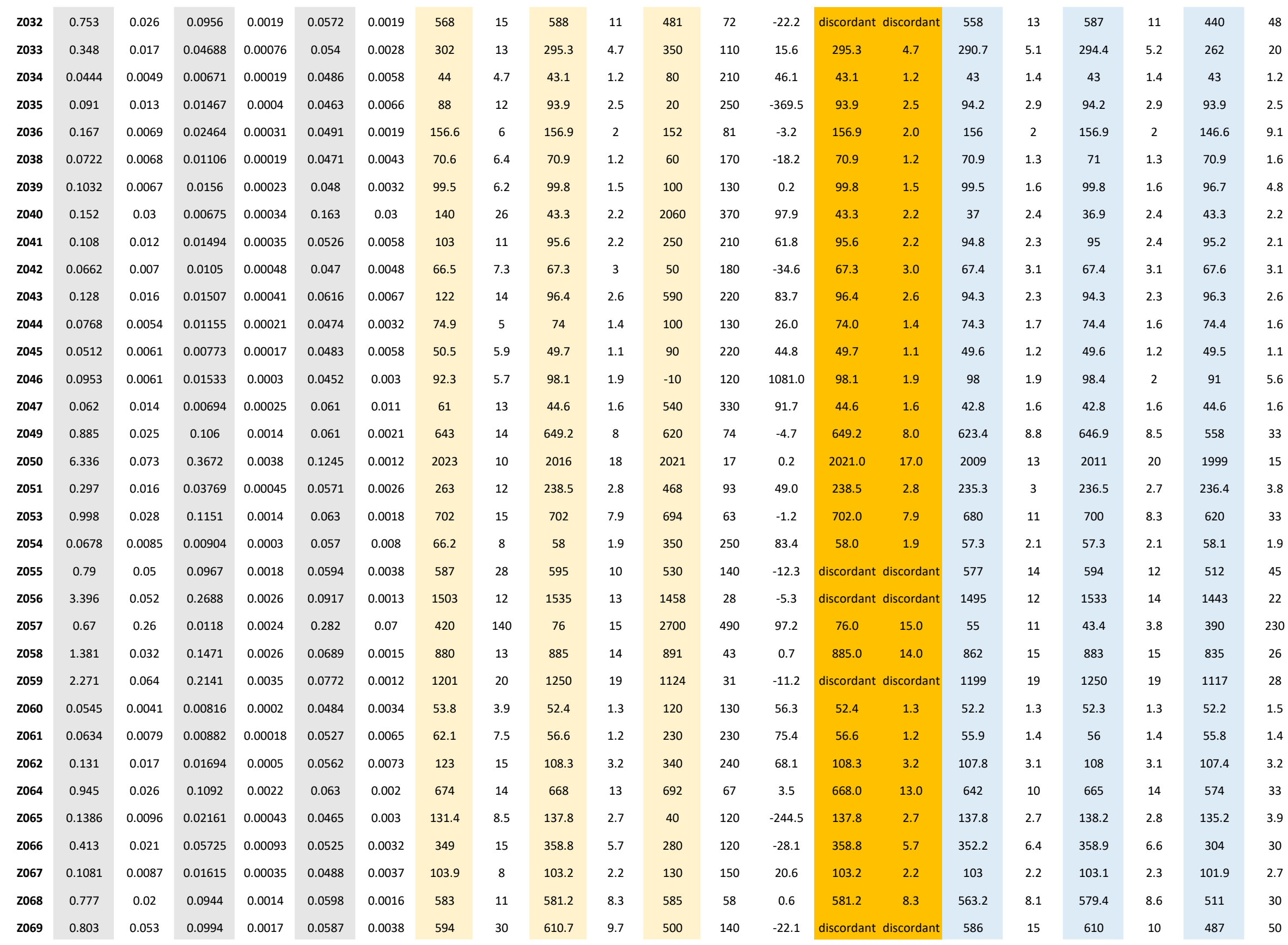




\begin{tabular}{|c|c|c|c|c|c|c|c|c|c|c|c|c|c|c|c|c|c|c|c|c|}
\hline Z070 & 0.0461 & 0.0052 & 0.00713 & 0.00016 & 0.0458 & 0.0048 & 45.7 & 5 & 45.8 & 1.1 & 40 & 190 & -14.5 & 45.8 & 1.1 & 46.1 & 1 & 46.1 & 1 & 45.8 \\
\hline $\mathrm{Z} 071$ & 0.073 & 0.005 & 0.01116 & 0.00022 & 0.0478 & 0.0035 & 71.4 & 4.7 & 71.5 & 1.4 & 90 & 140 & 20.6 & 71.5 & 1.4 & 71.5 & 1.6 & 71.5 & 1.5 & 71.1 \\
\hline zo72 & 0.96 & 0.044 & 0.1058 & 0.0016 & 0.0652 & 0.0024 & 681 & 23 & 648.2 & 9.1 & 764 & 83 & 15.2 & 648.2 & 9.1 & 637 & 11 & 643.7 & 9 & 612 \\
\hline $\mathrm{z} 073$ & 0.082 & 0.01 & 0.01428 & 0.00035 & 0.0422 & 0.0053 & 79.6 & 9.4 & 91.4 & 2.2 & -140 & 200 & 165.3 & 91.4 & 2.2 & 91.7 & 2.5 & 92 & 2.5 & 90.1 \\
\hline $\mathrm{Z} 075$ & 0.1615 & 0.0086 & 0.02423 & 0.00032 & 0.0485 & 0.0027 & 151.7 & 7.5 & 154.3 & 2 & 120 & 110 & -28.6 & 154.3 & 2.0 & 152.9 & 2.3 & 154.4 & 2.2 & 134 \\
\hline Z076 & 0.153 & 0.026 & 0.01034 & 0.00023 & 0.104 & 0.015 & 142 & 22 & 66.3 & 1.5 & 1390 & 300 & 95.2 & 66.3 & 1.5 & 61.2 & 1.1 & 61.2 & 1.1 & 66.3 \\
\hline zo77 & 1.788 & 0.065 & 0.1776 & 0.0045 & 0.0734 & 0.0012 & 1039 & 24 & 1053 & 25 & 1022 & 34 & -3.0 & 1053.0 & 25.0 & 1030 & 25 & 1052 & 25 & 989 \\
\hline $\mathrm{z} 078$ & 0.0508 & 0.0054 & 0.00823 & 0.00016 & 0.0439 & 0.0043 & 50.2 & 5.2 & 52.8 & 1 & -20 & 180 & 364.0 & 52.8 & 1.0 & 53 & 1.1 & 53 & 1.1 & 52.8 \\
\hline Z079 & 1.472 & 0.04 & 0.1512 & 0.0025 & 0.0707 & 0.0019 & 917 & 17 & 908 & 14 & 938 & 55 & 3.2 & 908.0 & 14.0 & 887 & 16 & 904 & 15 & 839 \\
\hline zo80 & 0.06 & 0.011 & 0.00824 & 0.00027 & 0.0514 & 0.0079 & 58.5 & 9.9 & 52.9 & 1.7 & 200 & 260 & 73.6 & 52.9 & 1.7 & 52.8 & 1.6 & 52.8 & 1.6 & 52.6 \\
\hline zo81 & 0.0457 & 0.0045 & 0.00734 & 0.00017 & 0.0451 & 0.0043 & 45.3 & 4.4 & 47.2 & 1.1 & -10 & 170 & 572.0 & 47.2 & 1.1 & 47.3 & 1.1 & 47.3 & 1.1 & 47.1 \\
\hline $\mathrm{z} 082$ & 0.056 & 0.0095 & 0.00796 & 0.00017 & 0.0538 & 0.0092 & 54.9 & 9 & 51.1 & 1.1 & 210 & 290 & 75.7 & 51.1 & 1.1 & 50.7 & 1.3 & 50.7 & 1.3 & 50.7 \\
\hline Z083 & 0.0748 & 0.0062 & 0.01092 & 0.00022 & 0.05 & 0.0043 & 73.1 & 5.8 & 70 & 1.4 & 160 & 160 & 56.3 & 70.0 & 1.4 & 69.8 & 1.6 & 69.8 & 1.6 & 70 \\
\hline zo86 & 1.902 & 0.069 & 0.1783 & 0.0034 & 0.0782 & 0.0023 & 1079 & 24 & 1058 & 18 & 1143 & 58 & 7.4 & 1058.0 & 18.0 & 1043 & 19 & 1053 & 19 & 1035 \\
\hline $\mathrm{Z} 087$ & 0.0909 & 0.0082 & 0.01269 & 0.00025 & 0.0519 & 0.0044 & 88 & 7.6 & 81.3 & 1.6 & 230 & 160 & 64.7 & 81.3 & 1.6 & 80.9 & 1.7 & 80.8 & 1.7 & 81.3 \\
\hline Z088 & 1.752 & 0.027 & 0.1774 & 0.0021 & 0.072 & 0.001 & 1030 & 11 & 1053 & 12 & 982 & 29 & -7.2 & discordant & discordant & 1023.9 & 9.9 & 1052 & 12 & 967 \\
\hline Z089 & 0.072 & 0.017 & 0.01148 & 0.00039 & 0.047 & 0.011 & 70 & 15 & 73.6 & 2.5 & -70 & 330 & 205.1 & 73.6 & 2.5 & 73.6 & 3.1 & 73 & 2.8 & 72.4 \\
\hline Z090 & 0.152 & 0.069 & 0.01319 & 0.0009 & 0.088 & 0.033 & 154 & 64 & 84.4 & 5.7 & 810 & 480 & 89.6 & 84.4 & 5.7 & 79 & 2.3 & 79 & 2.3 & 84.2 \\
\hline Z091 & 0.0918 & 0.0097 & 0.01329 & 0.00028 & 0.0505 & 0.0055 & 88.8 & 8.9 & 85.1 & 1.8 & 170 & 200 & 49.9 & 85.1 & 1.8 & 84.6 & 2 & 84.8 & 2 & 83.5 \\
\hline $\mathrm{Z} 092$ & 0.0675 & 0.0095 & 0.01084 & 0.00032 & 0.0461 & 0.0071 & 65.9 & 9 & 69.5 & 2.1 & -20 & 250 & 447.5 & 69.5 & 2.1 & 69.7 & 2.3 & 69.7 & 2.3 & 69.2 \\
\hline Z093 & 0.115 & 0.012 & 0.01444 & 0.00037 & 0.0593 & 0.0064 & 110 & 11 & 92.4 & 2.4 & 460 & 210 & 79.9 & 92.4 & 2.4 & 90.8 & 2.5 & 91 & 2.5 & 89.4 \\
\hline Z095 & 0.087 & 0.017 & 0.01345 & 0.00048 & 0.0462 & 0.0087 & 83 & 16 & 86.1 & 3.1 & -40 & 300 & 315.3 & 86.1 & 3.1 & 86.2 & 3 & 86.2 & 3 & 86.1 \\
\hline Z096 & 0.0532 & 0.004 & 0.0079 & 0.00022 & 0.0491 & 0.0038 & 52.5 & 3.9 & 50.7 & 1.4 & 140 & 140 & 63.8 & 50.7 & 1.4 & 50.2 & 1.4 & 50.2 & 1.4 & 50.7 \\
\hline Z097 & 0.131 & 0.018 & 0.01516 & 0.00043 & 0.0614 & 0.0074 & 123 & 16 & 97 & 2.7 & 500 & 210 & 80.6 & 97.0 & 2.7 & 95 & 2.6 & 95.2 & 2.6 & 96.8 \\
\hline Z098 & 0.082 & 0.014 & 0.00792 & 0.0002 & 0.074 & 0.012 & 79 & 13 & 50.9 & 1.3 & 750 & 300 & 93.2 & 50.9 & 1.3 & 49.5 & 1.5 & 49.5 & 1.5 & 50.7 \\
\hline Z099 & 0.741 & 0.033 & 0.0876 & 0.0012 & 0.0613 & 0.0022 & 561 & 19 & 541.1 & 7.1 & 627 & 77 & 13.7 & 541.1 & 7.1 & 526 & 10 & 538 & 7.1 & 491 \\
\hline Z101 & 0.247 & 0.031 & 0.00871 & 0.00026 & 0.204 & 0.023 & 221 & 26 & 55.9 & 1.6 & 2730 & 220 & 98.0 & 55.9 & 1.6 & 44.8 & 1.7 & 44.6 & 1.7 & 55.9 \\
\hline Z103 & 0.1734 & 0.004 & 0.0258 & 0.00031 & 0.04868 & 0.00097 & 162.3 & 3.4 & 164.2 & 2 & 131 & 44 & -25.3 & 164.2 & 2.0 & 162.2 & 2.2 & 164.2 & 2 & 131 \\
\hline Z104 & 0.0571 & 0.0061 & 0.00841 & 0.0002 & 0.0499 & 0.0057 & 56.2 & 5.8 & 54 & 1.3 & 150 & 210 & 64.0 & 54.0 & 1.3 & 53.8 & 1.5 & 53.8 & 1.5 & 54 \\
\hline Z105 & 0.063 & 0.0084 & 0.00996 & 0.00032 & 0.0471 & 0.0069 & 61.7 & 8 & 63.9 & 2 & 20 & 250 & -219.5 & 63.9 & 2.0 & 64 & 2.3 & 64 & 2.3 & 63.7 \\
\hline Z106 & 0.0519 & 0.0037 & 0.00768 & 0.00019 & 0.049 & 0.003 & 51.4 & 3.5 & 49.3 & 1.2 & 140 & 120 & 64.8 & 49.3 & 1.2 & 49.1 & 1.2 & 49.2 & 1.2 & 48.9 \\
\hline Z107 & 1.968 & 0.051 & 0.1909 & 0.0029 & 0.0759 & 0.002 & 1103 & 17 & 1126 & 16 & 1084 & 55 & -3.9 & 1126.0 & 16.0 & 1088 & 14 & 1124 & 16 & 1037 \\
\hline $\mathrm{Z} 108$ & 2.229 & 0.052 & 0.2061 & 0.0029 & 0.0789 & 0.0012 & 1189 & 16 & 1208 & 16 & 1167 & 30 & -3.5 & 1167.0 & 30.0 & 1180 & 16 & 1207 & 16 & 1138 \\
\hline Z109 & 0.0919 & 0.0068 & 0.01358 & 0.00024 & 0.0489 & 0.0033 & 89 & 6.3 & 87 & 1.5 & 140 & 130 & 37.9 & 87.0 & 1.5 & 86.8 & 1.6 & 86.8 & 1.6 & 86.9 \\
\hline
\end{tabular}




\begin{tabular}{|c|c|c|c|c|c|c|c|c|c|c|c|c|c|c|c|c|c|c|c|c|}
\hline $\mathrm{Z110}$ & 0.264 & 0.017 & 0.03788 & 0.00064 & 0.0506 & 0.0031 & 237 & 14 & 239.7 & 4 & 200 & 120 & -19.9 & 239.7 & 4.0 & 238.4 & 4.3 & 239.7 & 4.1 & 229 \\
\hline Z111 & 0.771 & 0.018 & 0.0952 & 0.0011 & 0.0585 & 0.001 & 580 & 10 & 586.3 & 6.5 & 554 & 41 & -5.8 & discordant & discordant & 569.7 & 7.9 & 585.4 & 6.6 & 511 \\
\hline Z112 & 0.0887 & 0.008 & 0.0141 & 0.0003 & 0.0459 & 0.0042 & 86 & 7.4 & 90.3 & 1.9 & 0 & 160 & \#DIV/0! & 90.3 & 1.9 & 90.3 & 2.1 & 90.5 & 2.1 & 89.3 \\
\hline $\mathrm{Z113}$ & 0.0913 & 0.0074 & 0.01386 & 0.00029 & 0.0482 & 0.0042 & 88.5 & 6.9 & 88.7 & 1.8 & 100 & 160 & 11.3 & 88.7 & 1.8 & 88.6 & 2 & 88.7 & 2 & 88.6 \\
\hline Z114 & 0.066 & 0.0061 & 0.00799 & 0.00018 & 0.06 & 0.0054 & 64.7 & 5.8 & 51.3 & 1.2 & 520 & 180 & 90.1 & 51.3 & 1.2 & 50.5 & 1.2 & 50.5 & 1.2 & 51.2 \\
\hline $\mathrm{Z115}$ & 0.0439 & 0.0052 & 0.0055 & 0.00026 & 0.0604 & 0.008 & 43.5 & 5.1 & 35.3 & 1.7 & 470 & 250 & 92.5 & 35.3 & 1.7 & 34.7 & 1.7 & 34.7 & 1.7 & 35.3 \\
\hline $\mathrm{Z116}$ & 0.093 & 0.015 & 0.00849 & 0.0003 & 0.081 & 0.014 & 89 & 14 & 54.5 & 1.9 & 900 & 360 & 93.9 & 54.5 & 1.9 & 52.3 & 2.3 & 52.2 & 2.3 & 54.5 \\
\hline Z117 & 0.0473 & 0.0039 & 0.00737 & 0.00024 & 0.0464 & 0.0032 & 46.9 & 3.8 & 47.3 & 1.6 & 40 & 130 & -18.3 & 47.3 & 1.6 & 47.4 & 1.6 & 47.4 & 1.5 & 47.2 \\
\hline Z118 & 0.256 & 0.013 & 0.03594 & 0.00051 & 0.0517 & 0.0025 & 231 & 10 & 227.6 & 3.2 & 260 & 100 & 12.5 & 227.6 & 3.2 & 225.8 & 3.4 & 227.2 & 3.3 & 211 \\
\hline Z119 & 0.2475 & 0.0083 & 0.03488 & 0.00038 & 0.0517 & 0.0017 & 224.3 & 6.8 & 221 & 2.3 & 261 & 73 & 15.3 & 221.0 & 2.3 & 217.2 & 2.8 & 220.4 & 2.5 & 192 \\
\hline $\mathrm{Z120}$ & 3.42 & 0.12 & 0.2685 & 0.0039 & 0.0925 & 0.0031 & 1506 & 27 & 1533 & 20 & 1463 & 65 & -4.8 & 1463.0 & 65.0 & 1482 & 17 & 1528 & 20 & 1406 \\
\hline
\end{tabular}




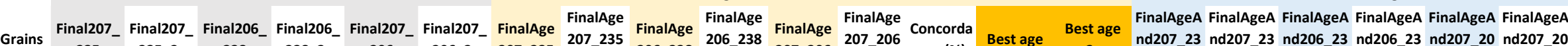

\begin{tabular}{|c|c|c|c|c|c|c|c|c|c|c|c|c|c|c|c|c|c|c|c|c|c|}
\hline Grains & 235 & 235_2s & 238 & $238 \_2 s$ & 206 & $206 \_2 s$ & 207_235 & $\begin{array}{c}207 \_235 \\
-2 s \\
\end{array}$ & 206_238 & $\begin{array}{c}206 \_238 \\
-2 s \\
\end{array}$ & 207_206 & $\begin{array}{c}207 \_206 \\
-2 s \\
\end{array}$ & nce (\%) & Best age & $2 s$ & $\begin{array}{c}\text { nd207_23 } \\
5\end{array}$ & $\begin{array}{c}\text { nd207_23 } \\
5 \_2 s\end{array}$ & $\begin{array}{c}\text { nd206_23 } \\
8 \\
\end{array}$ & $\begin{array}{c}\text { nd206_23 } \\
8 \_2 s\end{array}$ & $\begin{array}{c}3 \text { nd207_20 } \\
6\end{array}$ & $\begin{array}{c}\text { nd207_2 } \\
6 \_2 s \\
\end{array}$ \\
\hline Z001 & 0.1024 & 0.0039 & 0.01534 & 0.00028 & 0.049 & 0.0019 & 98.9 & 3.6 & 98.1 & 1.8 & 147 & 78 & 33.3 & 98.1 & 1.8 & 98 & 1.8 & 98.1 & 1.9 & 97.7 & 1.8 \\
\hline Z002 & 0.0899 & 0.0081 & 0.01382 & 0.00038 & 0.0476 & 0.0045 & 86.9 & 7.5 & 88.5 & 2.4 & 60 & 170 & -47.5 & 88.5 & 2.4 & 88.5 & 2.6 & 88.6 & 2.6 & 89.3 & 2.7 \\
\hline Z003 & 0.106 & 0.018 & 0.01563 & 0.00054 & 0.0493 & 0.0081 & 100 & 16 & 100 & 3.4 & 40 & 270 & -150.0 & 100.0 & 3.4 & 99.9 & 3.6 & 99.9 & 3.6 & 100 & 3.4 \\
\hline Z004 & 0.0988 & 0.0071 & 0.01509 & 0.00038 & 0.0482 & 0.0037 & 95.3 & 6.6 & 96.6 & 2.4 & 120 & 150 & 19.5 & 96.6 & 2.4 & 96.4 & 2.6 & 96.5 & 2.6 & 96.6 & 2.5 \\
\hline Z005 & 0.0993 & 0.0076 & 0.01321 & 0.00038 & 0.0551 & 0.0042 & 95.7 & 7 & 84.6 & 2.4 & 350 & 150 & 75.8 & 84.6 & 2.4 & 83.8 & 2.5 & 83.8 & 2.5 & 83.9 & 2.4 \\
\hline Z006 & 1.221 & 0.069 & 0.1264 & 0.0043 & 0.0696 & 0.0025 & 802 & 34 & 767 & 25 & 889 & 76 & 13.7 & 767.0 & 25.0 & 752 & 26 & 761 & 24 & 723 & 39 \\
\hline Z007 & 0.427 & 0.012 & 0.0572 & 0.0012 & 0.0545 & 0.0014 & 360.7 & 8.9 & 358.4 & 7.4 & 378 & 58 & 5.2 & 358.4 & 7.4 & 348.3 & 6.9 & 357.4 & 7.5 & 290 & 25 \\
\hline 2008 & 2.996 & 0.066 & 0.2413 & 0.004 & 0.0905 & 0.0018 & 1404 & 17 & 1393 & 21 & 1428 & 38 & 2.5 & 1428.0 & 38.0 & 1367 & 17 & 1387 & 22 & 1343 & 22 \\
\hline Z009 & 22.25 & 0.42 & 0.597 & 0.012 & 0.2715 & 0.0038 & 3192 & 18 & 3015 & 49 & 3312 & 22 & 9.0 & 3312.0 & 22.0 & 2956 & 53 & 2891 & 69 & 3005 & 43 \\
\hline 2010 & 0.619 & 0.023 & 0.0769 & 0.0013 & 0.0586 & 0.0019 & 487 & 15 & 477.7 & 8 & 547 & 78 & 12.7 & 477.7 & 8.0 & 461 & 8.8 & 474.2 & 7.8 & 394 & 32 \\
\hline Z011 & 1.293 & 0.052 & 0.1434 & 0.0028 & 0.0656 & 0.0024 & 839 & 23 & 864 & 16 & 761 & 79 & -13.5 & discordant & discordant & 814 & 18 & 861 & 16 & 683 & 58 \\
\hline Z012 & 0.187 & 0.011 & 0.02768 & 0.00053 & 0.0492 & 0.0028 & 173.5 & 9.1 & 176 & 3.4 & 150 & 110 & -17.3 & 176.0 & 3.4 & 175.5 & 3.6 & 176.1 & 3.6 & 176.2 & 3.5 \\
\hline 2013 & 3.511 & 0.068 & 0.266 & 0.004 & 0.0959 & 0.0015 & 1528 & 15 & 1520 & 20 & 1541 & 30 & 1.4 & 1541.0 & 30.0 & 1497 & 18 & 1515 & 22 & 1478 & 19 \\
\hline 2014 & 0.677 & 0.027 & 0.0834 & 0.0022 & 0.0586 & 0.0019 & 523 & 16 & 516 & 13 & 532 & 68 & 3.0 & 516.0 & 13.0 & 498 & 13 & 514 & 13 & 423 & 38 \\
\hline 2015 & 3.526 & 0.083 & 0.2484 & 0.006 & 0.103 & 0.0015 & 1531 & 19 & 1430 & 31 & 1676 & 27 & 14.7 & 1676.0 & 27.0 & 1418 & 32 & 1411 & 33 & 1430 & 31 \\
\hline Z016 & 0.0914 & 0.0069 & 0.01407 & 0.00032 & 0.0474 & 0.0036 & 88.5 & 6.4 & 90 & 2 & 90 & 140 & 0.0 & 90.0 & 2.0 & 89.9 & 2.1 & 90 & 2.2 & 89.3 & 2.3 \\
\hline 2017 & 0.1009 & 0.0046 & 0.01508 & 0.00024 & 0.0484 & 0.002 & 97.5 & 4.2 & 96.5 & 1.5 & 122 & 84 & 20.9 & 96.5 & 1.5 & 96.2 & 1.5 & 96.4 & 1.5 & 93.4 & 3.3 \\
\hline 2018 & 0.1204 & 0.0071 & 0.01838 & 0.00037 & 0.0483 & 0.0033 & 116.6 & 6.9 & 117.4 & 2.3 & 120 & 130 & 2.2 & 117.4 & 2.3 & 117 & 2.5 & 117.3 & 2.5 & 115.7 & 2.8 \\
\hline Z019 & 1.755 & 0.031 & 0.1663 & 0.0028 & 0.0762 & 0.0012 & 1028 & 11 & 991 & 16 & 1096 & 32 & 9.6 & 991.0 & 16.0 & 981 & 15 & 986 & 17 & 959 & 16 \\
\hline $\mathrm{ZO20}$ & 0.1393 & 0.0089 & 0.01629 & 0.0005 & 0.0628 & 0.0037 & 133.5 & 8.4 & 104.1 & 3.1 & 640 & 130 & 83.7 & 104.1 & 3.1 & 102.1 & 3.2 & 102.2 & 3.2 & 103.2 & 3.8 \\
\hline 2022 & 1.381 & 0.026 & 0.1353 & 0.0025 & 0.0742 & 0.001 & 882 & 12 & 818 & 14 & 1043 & 27 & 21.6 & discordant & discordant & 812 & 15 & 810 & 15 & 818 & 15 \\
\hline Z023 & 0.0675 & 0.0033 & 0.01079 & 0.00023 & 0.0452 & 0.002 & 66.2 & 3.2 & 69.2 & 1.5 & -10 & 84 & 792.0 & 69.2 & 1.5 & 69.3 & 1.5 & 69.3 & 1.5 & 69 & 1.5 \\
\hline Z024 & 0.215 & 0.041 & 0.01075 & 0.00044 & 0.138 & 0.019 & 192 & 31 & 68.9 & 2.8 & 2020 & 240 & 96.6 & 68.9 & 2.8 & 60.1 & 1.4 & 59.9 & 1.4 & 68.9 & 2.8 \\
\hline 2025 & 0.1053 & 0.0061 & 0.01574 & 0.00028 & 0.0481 & 0.0026 & 101.4 & 5.6 & 100.6 & 1.8 & 110 & 110 & 8.5 & 100.6 & 1.8 & 100.5 & 1.9 & 100.6 & 1.9 & 99.4 & 3.1 \\
\hline Z027 & 0.154 & 0.02 & 0.01388 & 0.00049 & 0.0809 & 0.0093 & 143 & 17 & 88.8 & 3.1 & 1070 & 230 & 91.7 & 88.8 & 3.1 & 84.9 & 2.8 & 84.7 & 2.8 & 88.8 & 3.1 \\
\hline 2028 & 0.0706 & 0.0074 & 0.01062 & 0.00053 & 0.0478 & 0.005 & 68.9 & 7 & 68.1 & 3.4 & 80 & 180 & 14.9 & 68.1 & 3.4 & 68 & 3.5 & 68 & 3.5 & 67.2 & 3.7 \\
\hline 2029 & 0.166 & 0.014 & 0.01584 & 0.00037 & 0.0768 & 0.0066 & 154 & 12 & 101.3 & 2.3 & 980 & 170 & 89.7 & 101.3 & 2.3 & 97.7 & 2.4 & 97.6 & 2.4 & 101.3 & 2.3 \\
\hline Z030 & 1.666 & 0.028 & 0.1592 & 0.0019 & 0.0754 & 0.0011 & 995 & 11 & 952 & 11 & 1075 & 29 & 11.4 & 952.0 & 11.0 & 947 & 10 & 947 & 11 & 945.1 & 9.9 \\
\hline 2031 & 0.415 & 0.018 & 0.0552 & 0.0011 & 0.0543 & 0.0024 & 353 & 12 & 346.2 & 6.9 & 354 & 92 & 2.2 & 346.2 & 6.9 & 338.9 & 7 & 345.2 & 7.2 & 289 & 24 \\
\hline Z032 & 4.485 & 0.075 & 0.2681 & 0.0044 & 0.1204 & 0.0016 & 1727 & 14 & 1531 & 22 & 1959 & 23 & 21.8 & discordant & discordant & 1506 & 24 & 1488 & 25 & 1531 & 22 \\
\hline
\end{tabular}




\begin{tabular}{|c|c|c|c|c|c|c|c|c|c|c|c|c|c|c|c|c|c|c|c|c|}
\hline Z033 & 0.0647 & 0.0098 & 0.0082 & 0.00049 & 0.0585 & 0.0095 & 63 & 9.3 & 52.6 & 3.2 & 360 & 300 & 85.4 & 52.6 & 3.2 & 51.8 & 3.3 & 51.8 & 3.3 & 51.2 \\
\hline Z034 & 3.467 & 0.077 & 0.2472 & 0.0052 & 0.1009 & 0.0017 & 1517 & 18 & 1423 & 27 & 1635 & 32 & 13.0 & 1635.0 & 32.0 & 1411 & 28 & 1405 & 29 & 1415 \\
\hline zo35 & 3.74 & 0.056 & 0.2762 & 0.0036 & 0.0973 & 0.0014 & 1579 & 12 & 1572 & 18 & 1574 & 26 & 0.1 & 1574.0 & 26.0 & 1552 & 15 & 1567 & 19 & 1523 \\
\hline Z037 & 0.608 & 0.016 & 0.0736 & 0.0013 & 0.0589 & 0.0012 & 481 & 10 & 457.4 & 8 & 553 & 46 & 17.3 & 457.4 & 8.0 & 451.4 & 7.6 & 455.1 & 8.2 & 426 \\
\hline Z038 & 0.1133 & 0.0075 & 0.01384 & 0.00034 & 0.0589 & 0.0039 & 108.6 & 6.8 & 88.6 & 2.1 & 490 & 140 & 81.9 & 88.6 & 2.1 & 87.3 & 2.2 & 87.3 & 2.2 & 87.9 \\
\hline Z039 & 0.937 & 0.024 & 0.1061 & 0.0017 & 0.0632 & 0.0016 & 670 & 13 & 650 & 10 & 711 & 54 & 8.6 & 650.0 & 10.0 & 634 & 10 & 647 & 10 & 590 \\
\hline Z040 & 0.0668 & 0.0058 & 0.00934 & 0.00027 & 0.0517 & 0.0047 & 65.4 & 5.5 & 60 & 1.7 & 220 & 170 & 72.7 & 60.0 & 1.7 & 59.6 & 1.9 & 59.6 & 1.9 & 60 \\
\hline Z041 & 0.546 & 0.023 & 0.0606 & 0.0016 & 0.0643 & 0.0025 & 441 & 15 & 379.4 & 9.8 & 723 & 80 & 47.5 & 379.4 & 9.8 & 373.2 & 9.6 & 374 & 10 & 368 \\
\hline Z042 & 0.445 & 0.013 & 0.0553 & 0.0017 & 0.0576 & 0.0011 & 373.3 & 9.3 & 347 & 11 & 506 & 43 & 31.4 & 347.0 & 11.0 & 343 & 10 & 345 & 11 & 330 \\
\hline zo43 & 0.704 & 0.024 & 0.0859 & 0.0015 & 0.0584 & 0.0019 & 539 & 14 & 531.3 & 8.9 & 522 & 72 & -1.8 & 531.3 & 8.9 & 515.5 & 9.5 & 529.2 & 9.2 & 432 \\
\hline Z044 & 0.0805 & 0.0099 & 0.00903 & 0.00031 & 0.0658 & 0.009 & 77.9 & 9.3 & 57.9 & 2 & 620 & 280 & 90.7 & 57.9 & 2.0 & 56.5 & 2.4 & 56.5 & 2.4 & 57.7 \\
\hline Z046 & 1.48 & 0.03 & 0.1518 & 0.0024 & 0.0693 & 0.0013 & 921 & 12 & 911 & 13 & 902 & 37 & -1.0 & 911.0 & 13.0 & 895 & 12 & 908 & 14 & 836 \\
\hline Z047 & 1.448 & 0.037 & 0.1475 & 0.0023 & 0.0698 & 0.0016 & 910 & 14 & 887 & 13 & 909 & 50 & 2.4 & 887.0 & 13.0 & 875 & 12 & 883 & 13 & 833 \\
\hline zo48 & 6.47 & 0.11 & 0.3386 & 0.0061 & 0.1359 & 0.0019 & 2040 & 14 & 1879 & 29 & 2172 & 25 & 13.5 & 2172.0 & 25.0 & 1861 & 34 & 1836 & 35 & 1884 \\
\hline Z049 & 0.129 & 0.01 & 0.01811 & 0.00044 & 0.051 & 0.0041 & 122.8 & 9.4 & 115.7 & 2.8 & 210 & 150 & 44.9 & 115.7 & 2.8 & 115.3 & 3 & 115.2 & 3 & 114.7 \\
\hline Z050 & 0.0863 & 0.0084 & 0.0123 & 0.00032 & 0.0509 & 0.0053 & 83.6 & 7.8 & 78.8 & 2 & 170 & 180 & 53.6 & 78.8 & 2.0 & 78.5 & 2.2 & 78.4 & 2.2 & 78.9 \\
\hline Z051 & 0.0954 & 0.0091 & 0.01318 & 0.00038 & 0.0519 & 0.0051 & 93.6 & 8.8 & 84.4 & 2.4 & 250 & 190 & 66.2 & 84.4 & 2.4 & 83.8 & 2.6 & 83.8 & 2.6 & 83.9 \\
\hline Z052 & 0.185 & 0.018 & 0.01498 & 0.00034 & 0.0871 & 0.0077 & 170 & 15 & 95.9 & 2.2 & 1290 & 180 & 92.6 & 95.9 & 2.2 & 90.4 & 2 & 90.2 & 2 & 95.9 \\
\hline Z053 & 0.078 & 0.0078 & 0.00987 & 0.00023 & 0.0562 & 0.0057 & 75.8 & 7.3 & 63.3 & 1.5 & 350 & 190 & 81.9 & 63.3 & 1.5 & 62.6 & 1.6 & 62.5 & 1.6 & 63.5 \\
\hline Z054 & 0.4416 & 0.0095 & 0.0582 & 0.001 & 0.0538 & 0.0012 & 371 & 6.7 & 364.9 & 6.1 & 353 & 49 & -3.4 & 364.9 & 6.1 & 356.7 & 5.8 & 363.8 & 6.3 & 283 \\
\hline Z055 & 0.1167 & 0.0098 & 0.01556 & 0.00038 & 0.0536 & 0.0046 & 111.5 & 8.9 & 99.5 & 2.4 & 310 & 170 & 67.9 & 99.5 & 2.4 & 98.6 & 2.6 & 98.6 & 2.6 & 99.4 \\
\hline Z057 & 2.934 & 0.059 & 0.1446 & 0.0022 & 0.1438 & 0.0022 & 1389 & 15 & 871 & 12 & 2269 & 26 & 61.6 & discordant & discordant & 812 & 13 & 791 & 12 & 871 \\
\hline Z058 & 13.86 & 0.2 & 0.533 & 0.0084 & 0.1845 & 0.0023 & 2739 & 14 & 2753 & 35 & 2692 & 20 & -2.3 & 2692.0 & 20.0 & 2727 & 18 & 2742 & 40 & 2656 \\
\hline Z059 & 0.69 & 0.016 & 0.0815 & 0.0017 & 0.0599 & 0.0014 & 532 & 9.9 & 505 & 10 & 597 & 57 & 15.4 & 505.0 & 10.0 & 496.6 & 9.8 & 502 & 11 & 460 \\
\hline $\mathrm{Z} 060$ & 0.748 & 0.032 & 0.0787 & 0.0013 & 0.0681 & 0.0032 & 568 & 19 & 488.4 & 7.6 & 829 & 92 & 41.1 & 488.4 & 7.6 & 478.6 & 7.4 & 480.6 & 8.2 & 474 \\
\hline $\mathrm{Z} 061$ & 0.2391 & 0.0075 & 0.03161 & 0.00056 & 0.0539 & 0.0016 & 217.4 & 6.2 & 200.6 & 3.5 & 349 & 66 & 42.5 & 200.6 & 3.5 & 199 & 3.5 & 199.4 & 3.6 & 193.7 \\
\hline $\mathrm{Z} 062$ & 0.704 & 0.017 & 0.0855 & 0.0012 & 0.0585 & 0.0015 & 540 & 10 & 529 & 7.3 & 536 & 55 & 1.3 & 529.0 & 7.3 & 517.6 & 7.2 & 527.1 & 7.6 & 455 \\
\hline 2063 & 0.85 & 0.02 & 0.1003 & 0.0014 & 0.06 & 0.0012 & 623 & 11 & 616.3 & 8.3 & 602 & 41 & -2.4 & 616.3 & 8.3 & 605.7 & 9.7 & 614.7 & 8.5 & 544 \\
\hline Z064 & 0.2502 & 0.0094 & 0.03281 & 0.00059 & 0.0545 & 0.0023 & 226.3 & 7.6 & 208.1 & 3.7 & 361 & 90 & 42.4 & 208.1 & 3.7 & 205.6 & 3.9 & 206.7 & 3.9 & 183 \\
\hline Z065 & 0.17 & 0.016 & 0.01417 & 0.00043 & 0.0843 & 0.0073 & 158 & 14 & 90.7 & 2.7 & 1160 & 170 & 92.2 & 90.7 & 2.7 & 86.6 & 2.6 & 86.4 & 2.6 & 90.7 \\
\hline Z067 & 2.39 & 0.13 & 0.2099 & 0.0067 & 0.0815 & 0.0041 & 1235 & 39 & 1228 & 36 & 1200 & 110 & -2.3 & 1200.0 & 110.0 & 1183 & 37 & 1216 & 38 & 1126 \\
\hline Z069 & 0.0678 & 0.0026 & 0.01002 & 0.00032 & 0.0486 & 0.0016 & 66.6 & 2.5 & 64.2 & 2 & 125 & 70 & 48.6 & 64.2 & 2.0 & 64.1 & 2.1 & 64.1 & 2.1 & 62.3 \\
\hline Z070 & 1.023 & 0.069 & 0.0691 & 0.0012 & 0.1064 & 0.0076 & 707 & 33 & 430.7 & 7.4 & 1650 & 130 & 73.9 & 430.7 & 7.4 & 407.3 & 8.9 & 403.3 & 9.2 & 430.7 \\
\hline Z071 & 1.537 & 0.028 & 0.1543 & 0.0021 & 0.0714 & 0.0012 & 944 & 11 & 925 & 11 & 961 & 35 & 3.7 & 925.0 & 11.0 & 912 & 10 & 921 & 12 & 878 \\
\hline
\end{tabular}




\begin{tabular}{|c|c|c|c|c|c|c|c|c|c|c|c|c|c|c|c|c|c|c|c|c|c|}
\hline Z073 & 2.157 & 0.045 & 0.1973 & 0.0031 & 0.0784 & 0.0014 & 1166 & 15 & 1161 & 16 & 1150 & 35 & -1.0 & 1161.0 & 16.0 & 1140 & 14 & 1157 & 17 & 1092 & 20 \\
\hline Z075 & 6.9 & 0.11 & 0.3731 & 0.0044 & 0.1329 & 0.002 & 2098 & 14 & 2043 & 21 & 2134 & 26 & 4.3 & 2134.0 & 26.0 & 2037 & 21 & 2028 & 24 & 2036 & 21 \\
\hline Z076 & 0.1166 & 0.0058 & 0.01414 & 0.00028 & 0.059 & 0.0027 & 111.7 & 5.3 & 90.5 & 1.8 & 530 & 100 & 82.9 & 90.5 & 1.8 & 89.2 & 1.8 & 89.2 & 1.8 & 91 & 2 \\
\hline Z077 & 0.112 & 0.011 & 0.01348 & 0.00039 & 0.0602 & 0.0058 & 107.1 & 9.7 & 86.3 & 2.5 & 490 & 190 & 82.4 & 86.3 & 2.5 & 85 & 2.6 & 84.9 & 2.6 & 85.7 & 2.7 \\
\hline Z078 & 0.0972 & 0.0049 & 0.01465 & 0.00031 & 0.0476 & 0.0021 & 94 & 4.6 & 93.7 & 2 & 106 & 90 & 11.6 & 93.7 & 2.0 & 93.6 & 2 & 93.6 & 2 & 93.6 & 2.2 \\
\hline Z079 & 1.356 & 0.027 & 0.1435 & 0.0022 & 0.0684 & 0.00098 & 869 & 12 & 864 & 12 & 876 & 30 & 1.4 & 864.0 & 12.0 & 850 & 12 & 862 & 13 & 823 & 16 \\
\hline zo80 & 1.557 & 0.027 & 0.1533 & 0.0023 & 0.0736 & 0.0013 & 954 & 11 & 919 & 13 & 1025 & 36 & 10.3 & 919.0 & 13.0 & 909 & 12 & 914 & 14 & 893 & 13 \\
\hline Z081 & 0.113 & 0.011 & 0.01195 & 0.00029 & 0.0686 & 0.0063 & 108.3 & 9.8 & 76.6 & 1.8 & 750 & 180 & 89.8 & 76.6 & 1.8 & 74.2 & 2.1 & 74.1 & 2.1 & 76.6 & 1.8 \\
\hline Z082 & 0.284 & 0.034 & 0.03252 & 0.00086 & 0.064 & 0.0076 & 254 & 29 & 206.3 & 5.4 & 610 & 250 & 66.2 & 206.3 & 5.4 & 201.9 & 5.3 & 201.7 & 5.3 & 205.6 & 6.2 \\
\hline Z083 & 1.396 & 0.037 & 0.1416 & 0.0023 & 0.0716 & 0.0017 & 886 & 15 & 853 & 13 & 961 & 50 & 11.2 & 853.0 & 13.0 & 841 & 13 & 849 & 14 & 827 & 22 \\
\hline Z084 & 0.959 & 0.026 & 0.1134 & 0.0021 & 0.0614 & 0.0016 & 681 & 13 & 692 & 12 & 650 & 53 & -6.5 & discordant & discordant & 668 & 11 & 691 & 13 & 588 & 37 \\
\hline Z085 & 0.0712 & 0.009 & 0.01029 & 0.00027 & 0.0505 & 0.0064 & 69.3 & 8.5 & 66 & 1.7 & 150 & 220 & 56.0 & 66.0 & 1.7 & 65.7 & 1.9 & 65.7 & 1.9 & 65.6 & 1.8 \\
\hline zo86 & 0.926 & 0.024 & 0.1056 & 0.0017 & 0.0642 & 0.0016 & 664 & 12 & 647 & 10 & 733 & 53 & 11.7 & 647.0 & 10.0 & 632.1 & 9.5 & 644 & 10 & 603 & 19 \\
\hline Z087 & 1.653 & 0.084 & 0.1627 & 0.0032 & 0.0747 & 0.0037 & 996 & 35 & 972 & 17 & 1031 & 97 & 5.7 & 972.0 & 17.0 & 933 & 20 & 963 & 18 & 883 & 36 \\
\hline Z088 & 2.389 & 0.075 & 0.2209 & 0.0055 & 0.0786 & 0.0015 & 1236 & 22 & 1286 & 29 & 1164 & 36 & -10.5 & discordant & discordant & 1230 & 22 & 1285 & 29 & 1146 & 30 \\
\hline Z089 & 0.1144 & 0.0069 & 0.01449 & 0.00035 & 0.0576 & 0.0033 & 109.7 & 6.2 & 92.7 & 2.2 & 460 & 120 & 79.8 & 92.7 & 2.2 & 91.6 & 2.2 & 91.6 & 2.2 & 92.5 & 2.3 \\
\hline$z 090$ & 4.317 & 0.062 & 0.3014 & 0.0048 & 0.1045 & 0.0017 & 1696 & 12 & 1698 & 24 & 1701 & 29 & 0.2 & 1701.0 & 29.0 & 1667 & 17 & 1691 & 25 & 1634 & 22 \\
\hline Zo91 & 2.27 & 0.1 & 0.193 & 0.0052 & 0.0859 & 0.0031 & 1197 & 32 & 1137 & 28 & 1325 & 67 & 14.2 & 1137.0 & 28.0 & 1110 & 28 & 1125 & 29 & 1096 & 33 \\
\hline Zo92 & 0.242 & 0.023 & 0.01883 & 0.00034 & 0.0955 & 0.009 & 222 & 19 & 120.2 & 2.2 & 1440 & 160 & 91.7 & 120.2 & 2.2 & 113.6 & 2.4 & 113.3 & 2.4 & 120.2 & 2.2 \\
\hline Z093 & 0.073 & 0.0054 & 0.01079 & 0.00023 & 0.0494 & 0.0038 & 71.3 & 5.1 & 69.2 & 1.5 & 140 & 140 & 50.6 & 69.2 & 1.5 & 69 & 1.6 & 69 & 1.6 & 69.6 & 1.7 \\
\hline Zo94 & 0.0924 & 0.0082 & 0.01372 & 0.00031 & 0.0499 & 0.0044 & 89.3 & 7.6 & 87.8 & 2 & 160 & 160 & 45.1 & 87.8 & 2.0 & 87.9 & 2.2 & 88 & 2.2 & 88 & 2.3 \\
\hline Z095 & 0.1024 & 0.0069 & 0.01343 & 0.00034 & 0.0556 & 0.0034 & 98.7 & 6.3 & 86 & 2.2 & 380 & 130 & 77.4 & 86.0 & 2.2 & 85.2 & 2.2 & 85.2 & 2.2 & 86 & 2.2 \\
\hline Zo96 & 0.0855 & 0.0034 & 0.01276 & 0.00025 & 0.0491 & 0.0019 & 83.2 & 3.2 & 81.7 & 1.6 & 149 & 80 & 45.2 & 81.7 & 1.6 & 81.5 & 1.6 & 81.6 & 1.6 & 81.2 & 1.6 \\
\hline Zo97 & 0.599 & 0.021 & 0.0761 & 0.0013 & 0.0576 & 0.0021 & 475 & 13 & 472.4 & 7.9 & 489 & 79 & 3.4 & 472.4 & 7.9 & 456.3 & 8.7 & 470.9 & 8.3 & 389 & 34 \\
\hline Z099 & 0.089 & 0.007 & 0.01326 & 0.00027 & 0.0491 & 0.0038 & 86.2 & 6.5 & 84.9 & 1.7 & 130 & 140 & 34.7 & 84.9 & 1.7 & 84.7 & 1.8 & 84.9 & 1.8 & 83.2 & 2.8 \\
\hline Z100 & 0.106 & 0.011 & 0.01079 & 0.00036 & 0.0729 & 0.0081 & 101 & 10 & 69.2 & 2.3 & 900 & 220 & 92.3 & 69.2 & 2.3 & 67 & 2.5 & 66.9 & 2.5 & 69.2 & 2.3 \\
\hline Z101 & 0.0963 & 0.0079 & 0.01299 & 0.00033 & 0.0544 & 0.0042 & 92.9 & 7.2 & 83.2 & 2.1 & 340 & 150 & 75.5 & 83.2 & 2.1 & 82.3 & 2.2 & 82.5 & 2.2 & 80.8 & 3.2 \\
\hline Z102 & 0.0951 & 0.0048 & 0.01371 & 0.00029 & 0.051 & 0.0025 & 92.1 & 4.5 & 87.8 & 1.8 & 230 & 100 & 61.8 & 87.8 & 1.8 & 87.4 & 1.9 & 87.5 & 1.9 & 87.8 & 1.9 \\
\hline Z103 & 0.0775 & 0.0079 & 0.01062 & 0.00039 & 0.0532 & 0.0049 & 75.4 & 7.4 & 68.1 & 2.5 & 260 & 170 & 73.8 & 68.1 & 2.5 & 67.5 & 2.4 & 67.6 & 2.4 & 67.2 & 2.8 \\
\hline Z104 & 0.1004 & 0.0068 & 0.01515 & 0.0003 & 0.0486 & 0.0032 & 96.9 & 6.3 & 97 & 1.9 & 130 & 130 & 25.4 & 97.0 & 1.9 & 96.8 & 2 & 96.9 & 2 & 97 & 1.9 \\
\hline Z105 & 2.936 & 0.069 & 0.2273 & 0.0037 & 0.0947 & 0.0022 & 1389 & 18 & 1320 & 19 & 1514 & 42 & 12.8 & 1514.0 & 42.0 & 1305 & 18 & 1307 & 21 & 1309 & 18 \\
\hline Z106 & 0.093 & 0.0089 & 0.01423 & 0.00049 & 0.0477 & 0.0044 & 89.8 & 8.2 & 91.1 & 3.1 & 80 & 170 & -13.9 & 91.1 & 3.1 & 91.1 & 3.2 & 91.2 & 3.2 & 90 & 3.5 \\
\hline Z109 & 0.0638 & 0.004 & 0.0097 & 0.00028 & 0.0492 & 0.0033 & 62.7 & 3.8 & 62.2 & 1.8 & 140 & 130 & 55.6 & 62.2 & 1.8 & 62.1 & 1.9 & 62.1 & 1.9 & 62.1 & 1.8 \\
\hline Z110 & 0.272 & 0.014 & 0.03805 & 0.00085 & 0.0527 & 0.0028 & 244 & 11 & 240.7 & 5.2 & 280 & 110 & 14.0 & 240.7 & 5.2 & 237.3 & 5.1 & 240.3 & 5.5 & 233.4 & 7.7 \\
\hline
\end{tabular}




\begin{tabular}{|c|c|c|c|c|c|c|c|c|c|c|c|c|c|c|c|c|c|c|c|c|}
\hline Z111 & 0.199 & 0.017 & 0.0287 & 0.001 & 0.0501 & 0.0046 & 182 & 14 & 182.6 & 6.4 & 190 & 170 & 3.9 & 182.6 & 6.4 & 183 & 7.1 & 182.6 & 6.8 & 177.2 \\
\hline Z112 & 0.317 & 0.04 & 0.01594 & 0.00061 & 0.143 & 0.016 & 275 & 31 & 101.9 & 3.9 & 2110 & 220 & 95.2 & 101.9 & 3.9 & 89.9 & 3.4 & 89.4 & 3.4 & 101.9 \\
\hline Z113 & 0.353 & 0.013 & 0.04723 & 0.00075 & 0.0546 & 0.002 & 305.9 & 9.9 & 297.5 & 4.6 & 372 & 76 & 20.0 & 297.5 & 4.6 & 291.6 & 4.3 & 296.4 & 4.7 & 270 \\
\hline Z114 & 0.244 & 0.02 & 0.03056 & 0.00087 & 0.0588 & 0.0052 & 219 & 16 & 194 & 5.4 & 450 & 180 & 56.9 & 194.0 & 5.4 & 191.4 & 5.6 & 192.1 & 5.8 & 189.6 \\
\hline Z115 & 3.326 & 0.096 & 0.2538 & 0.0047 & 0.0959 & 0.0027 & 1487 & 24 & 1457 & 24 & 1542 & 57 & 5.5 & 1542.0 & 57.0 & 1424 & 24 & 1446 & 27 & 1398 \\
\hline Z116 & 0.0867 & 0.007 & 0.01365 & 0.00037 & 0.0465 & 0.004 & 84.1 & 6.5 & 87.4 & 2.4 & 30 & 150 & -191.3 & 87.4 & 2.4 & 87.5 & 2.5 & 87.6 & 2.5 & 87.5 \\
\hline Z117 & 0.727 & 0.025 & 0.0729 & 0.0016 & 0.073 & 0.0021 & 553 & 14 & 453.4 & 9.5 & 996 & 59 & 54.5 & 453.4 & 9.5 & 445.2 & 9.5 & 444 & 9.6 & 452.6 \\
\hline Z118 & 0.0929 & 0.0081 & 0.01363 & 0.00031 & 0.0505 & 0.0048 & 89.8 & 7.5 & 87.3 & 2 & 170 & 170 & 48.6 & 87.3 & 2.0 & 87.1 & 2.3 & 87.1 & 2.3 & 87.2 \\
\hline Z119 & 0.615 & 0.021 & 0.0775 & 0.0014 & 0.0582 & 0.0019 & 486 & 13 & 481.2 & 8.5 & 514 & 70 & 6.4 & 481.2 & 8.5 & 464.1 & 9.1 & 477.6 & 9.3 & 400 \\
\hline $\mathrm{Z120}$ & 0.0896 & 0.0086 & 0.0142 & 0.00034 & 0.0457 & 0.0044 & 86.6 & 8 & 90.9 & 2.1 & 30 & 180 & -203.0 & 90.9 & 2.1 & 91 & 2.4 & 91.1 & 2.4 & 90.7 \\
\hline Z121 & 0.2832 & 0.0085 & 0.03972 & 0.00079 & 0.0519 & 0.0011 & 252.8 & 6.7 & 251.1 & 4.9 & 272 & 49 & 7.7 & 251.1 & 4.9 & 246.9 & 4.8 & 250.7 & 4.9 & 215 \\
\hline Z122 & 0.0592 & 0.0043 & 0.00878 & 0.0002 & 0.0495 & 0.0038 & 58.2 & 4.1 & 56.4 & 1.3 & 150 & 150 & 62.4 & 56.4 & 1.3 & 56.2 & 1.4 & 56.3 & 1.4 & 56 \\
\hline Z123 & 0.119 & 0.012 & 0.01503 & 0.00039 & 0.0581 & 0.0061 & 114 & 11 & 96.2 & 2.5 & 400 & 180 & 76.0 & 96.2 & 2.5 & 94.6 & 2.7 & 94.7 & 2.7 & 95.5 \\
\hline Z124 & 1.881 & 0.064 & 0.1816 & 0.0033 & 0.0755 & 0.0024 & 1071 & 22 & 1075 & 18 & 1060 & 64 & -1.4 & 1075.0 & 18.0 & 1032 & 17 & 1069 & 19 & 957 \\
\hline Z125 & 0.0976 & 0.0034 & 0.01491 & 0.00032 & 0.0477 & 0.0015 & 94.4 & 3.1 & 95.4 & 2 & 88 & 64 & -8.4 & 95.4 & 2.0 & 95 & 2.1 & 95.4 & 2.1 & 88.8 \\
\hline Z126 & 0.0662 & 0.0031 & 0.01035 & 0.00023 & 0.0467 & 0.0023 & 65 & 3 & 66.3 & 1.5 & 50 & 92 & -32.6 & 66.3 & 1.5 & 66.4 & 1.6 & 66.4 & 1.6 & 66.3 \\
\hline Z127 & 0.828 & 0.03 & 0.0779 & 0.0028 & 0.0788 & 0.0038 & 615 & 18 & 483 & 17 & 1137 & 94 & 57.5 & 483.0 & 17.0 & 473 & 18 & 471 & 18 & 483 \\
\hline $\mathrm{Z128}$ & 0.1056 & 0.0075 & 0.0155 & 0.00033 & 0.0496 & 0.0036 & 101.6 & 6.9 & 99.2 & 2.1 & 150 & 130 & 33.9 & 99.2 & 2.1 & 98.9 & 2.2 & 99 & 2.2 & 98.4 \\
\hline Z129 & 0.114 & 0.01 & 0.01705 & 0.00037 & 0.0497 & 0.0048 & 110.8 & 9.8 & 109 & 2.4 & 130 & 170 & 16.2 & 109.0 & 2.4 & 108.6 & 2.5 & 108.8 & 2.5 & 106.7 \\
\hline Z130 & 0.0925 & 0.0085 & 0.01363 & 0.00037 & 0.0494 & 0.0047 & 89.3 & 7.8 & 87.3 & 2.4 & 130 & 170 & 32.8 & 87.3 & 2.4 & 87.9 & 2.7 & 87.9 & 2.7 & 88 \\
\hline Z131 & 0.1 & 0.01 & 0.01359 & 0.00039 & 0.0525 & 0.0051 & 95.8 & 9.2 & 87 & 2.5 & 270 & 190 & 67.8 & 87.0 & 2.5 & 86.4 & 2.6 & 86.4 & 2.6 & 86.8 \\
\hline Z132 & 0.626 & 0.022 & 0.0775 & 0.0014 & 0.0592 & 0.0022 & 495 & 15 & 480.8 & 8.6 & 544 & 80 & 11.6 & 480.8 & 8.6 & 466.2 & 9 & 478.4 & 8.9 & 405 \\
\hline Z133 & 0.0775 & 0.0046 & 0.01049 & 0.0002 & 0.0545 & 0.0033 & 75.6 & 4.3 & 67.3 & 1.3 & 340 & 130 & 80.2 & 67.3 & 1.3 & 66.7 & 1.3 & 66.7 & 1.3 & 67 \\
\hline Z134 & 2.164 & 0.056 & 0.194 & 0.0032 & 0.0804 & 0.002 & 1171 & 17 & 1143 & 17 & 1202 & 53 & 4.9 & 1143.0 & 17.0 & 1120 & 17 & 1140 & 19 & 1090 \\
\hline Z135 & 0.0904 & 0.0052 & 0.01323 & 0.00029 & 0.0503 & 0.003 & 87.7 & 4.8 & 84.7 & 1.8 & 180 & 110 & 52.9 & 84.7 & 1.8 & 84.4 & 1.9 & 84.5 & 1.9 & 83.8 \\
\hline Z136 & 0.0515 & 0.0033 & 0.00756 & 0.00016 & 0.0496 & 0.0032 & 50.9 & 3.2 & 48.5 & 1 & 200 & 140 & 75.8 & 48.5 & 1.0 & 48.3 & 1 & 48.3 & 1 & 48.5 \\
\hline Z137 & 0.118 & 0.014 & 0.01689 & 0.0006 & 0.0512 & 0.0061 & 112 & 12 & 108 & 3.8 & 210 & 220 & 48.6 & 108.0 & 3.8 & 107.2 & 4.1 & 107.4 & 4.2 & 107.6 \\
\hline Z138 & 2.905 & 0.062 & 0.236 & 0.004 & 0.0893 & 0.0015 & 1381 & 16 & 1365 & 21 & 1406 & 33 & 2.9 & 1406.0 & 33.0 & 1343 & 17 & 1359 & 22 & 1322 \\
\hline Z140 & 0.0635 & 0.0027 & 0.00904 & 0.00025 & 0.0512 & 0.002 & 62.5 & 2.6 & 58 & 1.6 & 236 & 84 & 75.4 & 58.0 & 1.6 & 57.7 & 1.7 & 57.7 & 1.7 & 58 \\
\hline
\end{tabular}




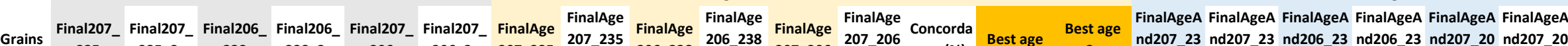

\begin{tabular}{|c|c|c|c|c|c|c|c|c|c|c|c|c|c|c|c|c|c|c|c|c|c|}
\hline Grains & 235 & 235_2s & 238 & $238 \_2 s$ & 206 & 206_2s & 207_235 & $\begin{array}{c}207 \_235 \\
\ldots 2 s\end{array}$ & 206_238 & $\begin{array}{c}206 \_238 \\
\ldots 2 s\end{array}$ & 207_206 & $\begin{array}{c}207 \_206 \\
\ldots 2 s\end{array}$ & nce (\%) & Best age & $2 s$ & $\begin{array}{c}\text { nd207_23 } \\
5\end{array}$ & $\begin{array}{c}\text { nd207_23 } \\
5 \_2 s\end{array}$ & $\begin{array}{c}3 \text { nd206_23 } \\
8\end{array}$ & $\begin{array}{c}\text { nd206_23 } \\
8 \_2 s\end{array}$ & $\begin{array}{c}3 \text { nd207_20 } \\
6\end{array}$ & $\begin{array}{c}\text { nd207_2 } \\
6 \_2 s\end{array}$ \\
\hline 2001 & 0.096 & 0.014 & 0.01555 & 0.00046 & 0.0447 & 0.0067 & 92 & 13 & 99.5 & 2.9 & -60 & 250 & 265.8 & 99.5 & 2.9 & 100 & 3.3 & 100 & 3.3 & 99.5 & 2.9 \\
\hline 2002 & 0.053 & 0.0041 & 0.00867 & 0.00019 & 0.0446 & 0.0036 & 52.3 & 4 & 55.7 & 1.2 & -30 & 140 & 285.7 & 55.7 & 1.2 & 55.8 & 1.3 & 55.9 & 1.3 & 55.4 & 1.3 \\
\hline 2003 & 0.088 & 0.016 & 0.01639 & 0.0005 & 0.0391 & 0.007 & 84 & 15 & 104.8 & 3.2 & -280 & 250 & 137.4 & 104.8 & 3.2 & 106 & 3.4 & 106.1 & 3.5 & 104.8 & 3.2 \\
\hline 2004 & 0.0331 & 0.005 & 0.00513 & 0.00042 & 0.0461 & 0.0057 & 33 & 4.8 & 33 & 2.7 & 0 & 210 & \#DIV/0! & 33.0 & 2.7 & 32.9 & 2.7 & 32.9 & 2.7 & 32.8 & 2.7 \\
\hline 2005 & 0.059 & 0.016 & 0.00679 & 0.00029 & 0.063 & 0.014 & 58 & 14 & 43.6 & 1.8 & 600 & 460 & 92.7 & 43.6 & 1.8 & 42.9 & 1.7 & 42.8 & 1.7 & 43.6 & 1.8 \\
\hline 2006 & 0.187 & 0.042 & 0.01903 & 0.00067 & 0.07 & 0.014 & 166 & 34 & 121.5 & 4.2 & 570 & 380 & 78.7 & 121.5 & 4.2 & 118.4 & 4.6 & 118.3 & 4.6 & 121.8 & 5.3 \\
\hline 2007 & 0.0604 & 0.0085 & 0.00909 & 0.00028 & 0.0485 & 0.0068 & 59.1 & 8 & 58.4 & 1.8 & 50 & 230 & -16.8 & 58.4 & 1.8 & 58.3 & 1.9 & 58.3 & 1.9 & 58.3 & 1.8 \\
\hline 2008 & 0.0557 & 0.0028 & 0.00869 & 0.00019 & 0.0471 & 0.0025 & 55 & 2.7 & 55.8 & 1.2 & 60 & 100 & 7.0 & 55.8 & 1.2 & 55.8 & 1.3 & 55.8 & 1.3 & 55.7 & 1.3 \\
\hline 2009 & 1.964 & 0.043 & 0.1942 & 0.0031 & 0.0734 & 0.0014 & 1102 & 15 & 1144 & 17 & 1019 & 38 & -12.3 & discordant & discordant & 1096 & 14 & 1143 & 17 & 1004 & 33 \\
\hline 2010 & 0.087 & 0.013 & 0.01225 & 0.00044 & 0.0538 & 0.009 & 84 & 12 & 78.5 & 2.8 & 180 & 280 & 56.4 & 78.5 & 2.8 & 77.9 & 3.1 & 77.9 & 3.1 & 77.8 & 2.8 \\
\hline 2011 & 0.105 & 0.023 & 0.01193 & 0.00096 & 0.067 & 0.016 & 99 & 20 & 76.4 & 6.1 & 390 & 390 & 80.4 & 76.4 & 6.1 & 74.8 & 6.4 & 74.8 & 6.4 & 75 & 6.9 \\
\hline Z012 & 0.0656 & 0.009 & 0.00976 & 0.00045 & 0.0489 & 0.0063 & 64.1 & 8.5 & 62.6 & 2.9 & 90 & 220 & 30.4 & 62.6 & 2.9 & 62.5 & 3 & 62.5 & 3 & 62.3 & 3 \\
\hline 2013 & 0.31 & 0.1 & 0.0274 & 0.0011 & 0.069 & 0.012 & 251 & 55 & 173.9 & 7.1 & 620 & 260 & 72.0 & 173.9 & 7.1 & 184 & 37 & 193 & 57 & 171.3 & 9.1 \\
\hline Z014 & 0.072 & 0.013 & 0.00947 & 0.00041 & 0.056 & 0.01 & 70 & 12 & 60.8 & 2.6 & 280 & 330 & 78.3 & 60.8 & 2.6 & 60.1 & 2.8 & 60.1 & 2.9 & 60.6 & 2.7 \\
\hline 2015 & 0.1074 & 0.0072 & 0.01682 & 0.00083 & 0.047 & 0.0021 & 103.3 & 6.6 & 107.5 & 5.3 & 60 & 85 & -79.2 & 107.5 & 5.3 & 107.5 & 5.4 & 107.7 & 5.4 & 103.4 & 7.6 \\
\hline 2016 & 0.0612 & 0.003 & 0.0093 & 0.00015 & 0.0477 & 0.0023 & 60.2 & 2.8 & 59.65 & 0.98 & 93 & 94 & 35.9 & 59.7 & 1.0 & 59.6 & 1 & 59.6 & 1 & 59.6 & 1 \\
\hline Z017 & 10.13 & 0.18 & 0.4759 & 0.0079 & 0.1543 & 0.0016 & 2445 & 17 & 2508 & 35 & 2393 & 17 & -4.8 & 2393.0 & 17.0 & 2438 & 20 & 2506 & 36 & 2382 & 18 \\
\hline Z018 & 0.0343 & 0.0022 & 0.00502 & 0.00011 & 0.0494 & 0.003 & 34.3 & 2.1 & 32.28 & 0.72 & 150 & 120 & 78.5 & 32.3 & 0.7 & 32.16 & 0.74 & 32.17 & 0.74 & 32.28 & 0.88 \\
\hline 2019 & 0.605 & 0.022 & 0.0799 & 0.0017 & 0.0544 & 0.0016 & 479 & 14 & 496 & 10 & 372 & 64 & -33.3 & 496.0 & 10.0 & 474 & 11 & 495 & 11 & 366 & 38 \\
\hline Z020 & 0.109 & 0.024 & 0.01037 & 0.00043 & 0.072 & 0.013 & 102 & 21 & 66.5 & 2.8 & 650 & 310 & 89.8 & 66.5 & 2.8 & 63.7 & 1.9 & 63.6 & 1.9 & 66.6 & 2.8 \\
\hline 2021 & 0.0348 & 0.0017 & 0.00532 & 0.00019 & 0.0472 & 0.0018 & 34.7 & 1.7 & 34.2 & 1.2 & 67 & 76 & 49.0 & 34.2 & 1.2 & 34.2 & 1.3 & 34.2 & 1.3 & 34.1 & 1.3 \\
\hline Z022 & 0.09 & 0.31 & 0.0122 & 0.0057 & -0.03 & 0.24 & -30 & 330 & 78 & 36 & -8200 & 7000 & 101.0 & 78.0 & 36.0 & 65 & 27 & 59 & 26 & 380 & 270 \\
\hline Z023 & 0.0529 & 0.0041 & 0.00823 & 0.00016 & 0.0461 & 0.0034 & 52.3 & 4 & 52.8 & 1 & 20 & 130 & -164.0 & 52.8 & 1.0 & 52.9 & 1.1 & 53.2 & 1.2 & 53.4 & 1.3 \\
\hline 2024 & 0.069 & 0.013 & 0.01077 & 0.00033 & 0.0464 & 0.0086 & 67 & 13 & 69.1 & 2.1 & -20 & 310 & 445.5 & 69.1 & 2.1 & 69.2 & 2.3 & 69.2 & 2.3 & 69 & 2.1 \\
\hline Z025 & 0.0546 & 0.0088 & 0.00791 & 0.00027 & 0.0498 & 0.0078 & 53.5 & 8.5 & 50.8 & 1.8 & 150 & 280 & 66.1 & 50.8 & 1.8 & 50.5 & 1.8 & 50.5 & 1.8 & 50.8 & 1.8 \\
\hline 2026 & 0.0432 & 0.0033 & 0.00649 & 0.00012 & 0.0485 & 0.0038 & 42.9 & 3.2 & 41.7 & 0.77 & 110 & 150 & 62.1 & 41.7 & 0.8 & 41.62 & 0.84 & 41.62 & 0.84 & 41.72 & 0.79 \\
\hline 2027 & 0.0302 & 0.0014 & 0.00463 & 0.00022 & 0.0474 & 0.0018 & 30.2 & 1.4 & 29.8 & 1.4 & 63 & 82 & 52.7 & 29.8 & 1.4 & 29.7 & 1.4 & 29.7 & 1.4 & 29.8 & 1.4 \\
\hline 2028 & 1.919 & 0.089 & 0.1896 & 0.0045 & 0.0733 & 0.0028 & 1083 & 30 & 1119 & 24 & 1001 & 77 & -11.8 & discordant & discordant & 1065 & 25 & 1116 & 24 & 987 & 41 \\
\hline 2029 & 0.0397 & 0.0038 & 0.00616 & 0.00022 & 0.0467 & 0.0043 & 39.4 & 3.7 & 39.6 & 1.4 & 30 & 160 & -32.0 & 39.6 & 1.4 & 39.6 & 1.4 & 39.6 & 1.4 & 39.6 & 1.4 \\
\hline 2030 & 0.0871 & 0.0079 & 0.012 & 0.00022 & 0.0525 & 0.0045 & 84.4 & 7.3 & 76.9 & 1.4 & 250 & 170 & 69.2 & 76.9 & 1.4 & 76.4 & 1.4 & 76.4 & 1.4 & 76.9 & 1.4 \\
\hline
\end{tabular}




\begin{tabular}{|c|c|c|c|c|c|c|c|c|c|c|c|c|c|c|c|c|c|c|c|c|c|}
\hline 2033 & 0.026 & 0.002 & 0.0041 & 0.00013 & 0.0475 & 0.004 & 26 & 2 & 26.35 & 0.83 & 60 & 150 & 56.1 & 26.4 & 0.8 & 26.33 & 0.89 & 26.33 & 0.89 & 26.16 & 0.98 \\
\hline Z034 & 0.0704 & 0.0025 & 0.01096 & 0.00018 & 0.0466 & 0.0017 & 69 & 2.3 & 70.3 & 1.2 & 45 & 72 & -56.2 & 70.3 & 1.2 & 70.3 & 1.2 & 70.4 & 1.2 & 69.5 & 1.7 \\
\hline Z035 & 1.431 & 0.047 & 0.1541 & 0.0043 & 0.0673 & 0.0012 & 899 & 20 & 923 & 24 & 841 & 37 & -9.8 & discordant & discordant & 890 & 22 & 922 & 24 & 811 & 32 \\
\hline Z036 & 0.0453 & 0.003 & 0.00739 & 0.00021 & 0.0453 & 0.0031 & 44.9 & 3 & 47.5 & 1.3 & -10 & 120 & 575.0 & 47.5 & 1.3 & 47.3 & 1.3 & 47.3 & 1.3 & 47.6 & 1.3 \\
\hline Z037 & 0.0499 & 0.004 & 0.00764 & 0.00018 & 0.0472 & 0.0037 & 49.4 & 3.9 & 49 & 1.2 & 70 & 150 & 30.0 & 49.0 & 1.2 & 49 & 1.2 & 49 & 1.2 & 49.3 & 1.3 \\
\hline Z038 & 0.0431 & 0.0051 & 0.00683 & 0.00021 & 0.046 & 0.0055 & 42.6 & 5 & 43.9 & 1.3 & 0 & 200 & \#DIV/0! & 43.9 & 1.3 & 43.9 & 1.4 & 43.9 & 1.4 & 43.7 & 1.3 \\
\hline Z039 & 0.0521 & 0.0082 & 0.00738 & 0.00023 & 0.0512 & 0.0074 & 51.2 & 7.7 & 47.4 & 1.4 & 150 & 210 & 68.4 & 47.4 & 1.4 & 46.5 & 1.1 & 46.5 & 1.1 & 47.4 & 1.4 \\
\hline Zo40 & 2.009 & 0.062 & 0.1917 & 0.0031 & 0.0759 & 0.0024 & 1115 & 22 & 1130 & 17 & 1075 & 66 & -5.1 & discordant & discordant & 1090 & 18 & 1129 & 17 & 1021 & 39 \\
\hline Z041 & 0.0864 & 0.0049 & 0.01343 & 0.00024 & 0.0464 & 0.0025 & 84 & 4.6 & 86 & 1.5 & 40 & 100 & -115.0 & 86.0 & 1.5 & 85.9 & 1.6 & 86.1 & 1.5 & 85.3 & 2.9 \\
\hline Z042 & 0.084 & 0.011 & 0.01407 & 0.00033 & 0.0429 & 0.0056 & 81 & 10 & 90.1 & 2.1 & -80 & 220 & 212.6 & 90.1 & 2.1 & 90.4 & 2.3 & 90.5 & 2.3 & 90.1 & 2.1 \\
\hline 2043 & 0.0313 & 0.003 & 0.0048 & 0.00011 & 0.0469 & 0.0044 & 31.3 & 3 & 30.89 & 0.73 & 40 & 170 & 22.8 & 30.9 & 0.7 & 30.87 & 0.75 & 30.87 & 0.75 & 30.89 & 0.73 \\
\hline Z044 & 0.0571 & 0.0055 & 0.00834 & 0.00023 & 0.0496 & 0.005 & 56.2 & 5.3 & 53.6 & 1.5 & 170 & 190 & 68.5 & 53.6 & 1.5 & 53.3 & 1.6 & 53.3 & 1.6 & 53.5 & 1.5 \\
\hline Z047 & 0.152 & 0.025 & 0.0203 & 0.0012 & 0.0536 & 0.009 & 140 & 22 & 129.8 & 7.7 & 210 & 290 & 38.2 & 129.8 & 7.7 & 130.8 & 8.6 & 130.9 & 8.6 & 131.9 & 8.5 \\
\hline Z048 & 0.0311 & 0.0025 & 0.00501 & 0.00026 & 0.0457 & 0.0035 & 31.1 & 2.4 & 32.2 & 1.7 & 10 & 140 & -222.0 & 32.2 & 1.7 & 32.3 & 1.7 & 32.3 & 1.7 & 32.1 & 1.7 \\
\hline Z049 & 0.1012 & 0.0058 & 0.01498 & 0.00032 & 0.0485 & 0.0024 & 97.7 & 5.4 & 95.9 & 2.1 & 125 & 98 & 23.3 & 95.9 & 2.1 & 95.7 & 2.1 & 95.8 & 2.1 & 96.4 & 2.4 \\
\hline Z050 & 0.0627 & 0.0041 & 0.01037 & 0.00025 & 0.0439 & 0.0027 & 61.7 & 3.9 & 66.5 & 1.6 & -60 & 110 & 210.8 & 66.5 & 1.6 & 66.8 & 1.6 & 66.8 & 1.6 & 65.9 & 1.8 \\
\hline Z051 & 0.117 & 0.022 & 0.01007 & 0.0004 & 0.088 & 0.016 & 109 & 20 & 64.6 & 2.6 & 960 & 390 & 93.3 & 64.6 & 2.6 & 60.6 & 2.5 & 60.6 & 2.5 & 63.9 & 2.6 \\
\hline Z052 & 0.1044 & 0.0062 & 0.01584 & 0.00024 & 0.0476 & 0.0027 & 100.6 & 5.7 & 101.3 & 1.5 & 90 & 110 & -12.6 & 101.3 & 1.5 & 101.4 & 1.6 & 101.4 & 1.6 & 101.3 & 1.5 \\
\hline 2053 & 0.0434 & 0.0068 & 0.00816 & 0.00029 & 0.0393 & 0.0065 & 42.9 & 6.6 & 52.4 & 1.9 & -220 & 250 & 123.8 & 52.4 & 1.9 & 52.8 & 2.1 & 52.8 & 2.1 & 52 & 1.9 \\
\hline Z054 & 0.027 & 0.002 & 0.004122 & 0.000096 & 0.0474 & 0.0034 & 27 & 2 & 26.52 & 0.61 & 80 & 140 & 66.9 & 26.5 & 0.6 & 26.49 & 0.63 & 26.49 & 0.63 & 26.39 & 0.66 \\
\hline Z055 & 0.117 & 0.0028 & 0.01835 & 0.00038 & 0.04625 & 0.00072 & 112.3 & 2.6 & 117.2 & 2.4 & 20 & 32 & -486.0 & 117.2 & 2.4 & 116.5 & 2.5 & 117.4 & 2.4 & 95.1 & 9.9 \\
\hline Z056 & 0.0341 & 0.0017 & 0.005486 & 0.00009 & 0.0453 & 0.0026 & 34 & 1.7 & 35.27 & 0.58 & -10 & 110 & 452.7 & 35.3 & 0.6 & 35.34 & 0.64 & 35.34 & 0.64 & 35.27 & 0.58 \\
\hline Z057 & 0.1439 & 0.0048 & 0.02172 & 0.00076 & 0.04795 & 0.00098 & 136.4 & 4.3 & 138.5 & 4.8 & 98 & 44 & -41.3 & 138.5 & 4.8 & 136.8 & 4.7 & 138.5 & 4.9 & 107 & 13 \\
\hline Z058 & 0.062 & 0.0062 & 0.01005 & 0.00027 & 0.0441 & 0.0037 & 60.8 & 5.9 & 64.5 & 1.7 & -20 & 160 & 422.5 & 64.5 & 1.7 & 64.6 & 1.7 & 64.7 & 1.7 & 63.8 & 2.1 \\
\hline Z059 & 0.0644 & 0.0071 & 0.01126 & 0.00057 & 0.0418 & 0.0044 & 63 & 6.8 & 72.2 & 3.6 & -150 & 170 & 148.1 & 72.2 & 3.6 & 72.7 & 3.7 & 72.7 & 3.7 & 71.1 & 3.6 \\
\hline 2060 & 0.0486 & 0.0041 & 0.00762 & 0.00015 & 0.0465 & 0.0041 & 48.1 & 4 & 48.94 & 0.96 & 40 & 160 & -22.4 & 48.9 & 1.0 & 49 & 1 & 49 & 1 & 48.76 & 0.97 \\
\hline Z061 & 0.068 & 0.011 & 0.0109 & 0.0011 & 0.0443 & 0.005 & 67 & 11 & 70 & 6.9 & -50 & 190 & 240.0 & 70.0 & 6.9 & 70.1 & 6.8 & 70.2 & 6.9 & 68 & 6.8 \\
\hline 2062 & 3.132 & 0.065 & 0.2348 & 0.0044 & 0.0968 & 0.0014 & 1440 & 16 & 1360 & 23 & 1562 & 27 & 12.9 & 1562.0 & 27.0 & 1352 & 24 & 1345 & 25 & 1363 & 24 \\
\hline Z063 & 0.0335 & 0.0045 & 0.0058 & 0.00042 & 0.0436 & 0.005 & 33.3 & 4.5 & 37.2 & 2.7 & -90 & 190 & 141.3 & 37.2 & 2.7 & 38.1 & 2.9 & 38.1 & 2.9 & 37.2 & 2.7 \\
\hline Z064 & 0.0827 & 0.0066 & 0.01346 & 0.00036 & 0.0443 & 0.0031 & 80.4 & 6.2 & 86.2 & 2.3 & -20 & 130 & 531.0 & 86.2 & 2.3 & 86.4 & 2.2 & 86.5 & 2.2 & 85.4 & 2.7 \\
\hline Z065 & 0.097 & 0.017 & 0.01421 & 0.00051 & 0.0499 & 0.0088 & 93 & 16 & 90.9 & 3.3 & 110 & 300 & 17.4 & 90.9 & 3.3 & 90.6 & 3.6 & 90.7 & 3.6 & 89.5 & 4.7 \\
\hline Z066 & 0.0527 & 0.0022 & 0.00834 & 0.0002 & 0.0458 & 0.0014 & 52.2 & 2.1 & 53.5 & 1.3 & 6 & 58 & -791.7 & 53.5 & 1.3 & 53.6 & 1.3 & 53.6 & 1.3 & 53.4 & 1.4 \\
\hline Z067 & 0.0214 & 0.0027 & 0.003601 & 0.000068 & 0.0434 & 0.0056 & 21.5 & 2.7 & 23.17 & 0.44 & -100 & 200 & 123.2 & 23.2 & 0.4 & 23.39 & 0.58 & 23.39 & 0.58 & 23.17 & 0.44 \\
\hline Z068 & 0.0567 & 0.0086 & 0.0095 & 0.00032 & 0.0421 & 0.0063 & 55.6 & 8.2 & 61 & 2 & -120 & 240 & 150.8 & 61.0 & 2.0 & 61.2 & 2.2 & 61.2 & 2.2 & 61 & 2 \\
\hline
\end{tabular}




\begin{tabular}{|c|c|c|c|c|c|c|c|c|c|c|c|c|c|c|c|c|c|c|c|c|c|}
\hline 2069 & 0.0564 & 0.0043 & 0.00832 & 0.00021 & 0.0484 & 0.0033 & 55.6 & 4.1 & 53.4 & 1.3 & 110 & 130 & 51.5 & 53.4 & 1.3 & 53.3 & 1.3 & 53.3 & 1.3 & 52.6 & 1.6 \\
\hline $\mathbf{Z 0 7 0}$ & 0.092 & 0.0075 & 0.01436 & 0.00031 & 0.0473 & 0.0039 & 89 & 7 & 91.9 & 2 & 60 & 150 & -53.2 & 91.9 & 2.0 & 91.9 & 2 & 92 & 2 & 91.5 & 2 \\
\hline Z071 & 0.098 & 0.018 & 0.01588 & 0.00054 & 0.045 & 0.0083 & 94 & 16 & 101.6 & 3.4 & -40 & 290 & 354.0 & 101.6 & 3.4 & 102.3 & 3.4 & 102.5 & 3.4 & 101.5 & 3.5 \\
\hline Z072 & 1.837 & 0.053 & 0.1883 & 0.0033 & 0.0709 & 0.0021 & 1056 & 19 & 1112 & 18 & 937 & 62 & -18.7 & discordant & discordant & 1043 & 16 & 1110 & 18 & 901 & 51 \\
\hline Z073 & 0.0698 & 0.0085 & 0.01069 & 0.00031 & 0.0473 & 0.0055 & 68.1 & 8 & 68.6 & 2 & 50 & 200 & -37.2 & 68.6 & 2.0 & 68.6 & 2 & 68.6 & 2 & 68.6 & 2 \\
\hline 2074 & 0.0346 & 0.0049 & 0.005 & 0.00018 & 0.0499 & 0.0064 & 34.4 & 4.7 & 32.1 & 1.1 & 120 & 220 & 73.3 & 32.1 & 1.1 & 32 & 1.1 & 32 & 1.1 & 32.1 & 1.1 \\
\hline Z075 & 0.059 & 0.021 & 0.00895 & 0.0005 & 0.054 & 0.019 & 55 & 20 & 57.4 & 3.2 & -50 & 530 & 214.8 & 57.4 & 3.2 & 57 & 4.1 & 57 & 4.1 & 57.4 & 3.2 \\
\hline Z076 & 0.0461 & 0.0036 & 0.00723 & 0.0002 & 0.0461 & 0.0032 & 45.7 & 3.5 & 46.4 & 1.3 & 20 & 120 & -132.0 & 46.4 & 1.3 & 46.5 & 1.2 & 46.5 & 1.2 & 46.3 & 1.3 \\
\hline Z077 & 0.542 & 0.036 & 0.0716 & 0.0039 & 0.0545 & 0.0014 & 435 & 26 & 445 & 24 & 383 & 56 & -16.2 & 445.0 & 24.0 & 430 & 23 & 445 & 24 & 350 & 34 \\
\hline 2078 & 0.11 & 0.015 & 0.01418 & 0.00067 & 0.0573 & 0.0074 & 108 & 15 & 90.7 & 4.2 & 370 & 230 & 75.5 & 90.7 & 4.2 & 89.5 & 4.2 & 89.6 & 4.2 & 89.3 & 4.8 \\
\hline Z079 & 0.164 & 0.063 & 0.01694 & 0.00079 & 0.057 & 0.011 & 126 & 27 & 108.3 & 5 & 250 & 200 & 56.7 & 108.3 & 5.0 & 105.2 & 2.5 & 105.3 & 2.5 & 102.2 & 7.4 \\
\hline Z080 & 0.818 & 0.037 & 0.1015 & 0.002 & 0.0584 & 0.0023 & 604 & 20 & 623 & 12 & 517 & 85 & -20.5 & discordant & discordant & 595 & 15 & 622 & 12 & 482 & 49 \\
\hline Z081 & 0.0231 & 0.0019 & 0.003669 & 0.000096 & 0.0463 & 0.0041 & 23.2 & 1.9 & 23.61 & 0.61 & 50 & 160 & 52.8 & 23.6 & 0.6 & 23.59 & 0.64 & 23.59 & 0.64 & 23.62 & 0.63 \\
\hline Z082 & 0.0505 & 0.0066 & 0.00789 & 0.00027 & 0.0475 & 0.0066 & 49.8 & 6.4 & 50.7 & 1.7 & 40 & 240 & -26.8 & 50.7 & 1.7 & 50.7 & 1.9 & 50.7 & 1.9 & 50.7 & 1.7 \\
\hline Z083 & 0.0253 & 0.0021 & 0.003645 & 0.000089 & 0.0502 & 0.0039 & 25.3 & 2 & 23.45 & 0.57 & 180 & 150 & 87.0 & 23.5 & 0.6 & 23.34 & 0.57 & 23.34 & 0.57 & 23.45 & 0.57 \\
\hline Z084 & 0.108 & 0.014 & 0.01609 & 0.00047 & 0.048 & 0.0072 & 103 & 13 & 102.9 & 3 & 70 & 270 & -47.0 & 102.9 & 3.0 & 102.9 & 3.4 & 102.9 & 3.4 & 102.9 & 3 \\
\hline Z085 & 0.0621 & 0.004 & 0.01005 & 0.00032 & 0.0453 & 0.0022 & 61.1 & 3.9 & 64.4 & 2.1 & -18 & 89 & 457.8 & 64.4 & 2.1 & 64.5 & 2.1 & 64.6 & 2.1 & 62.3 & 2.9 \\
\hline Z086 & 0.095 & 0.01 & 0.01466 & 0.00038 & 0.0474 & 0.0054 & 91.3 & 9.6 & 93.8 & 2.4 & 60 & 200 & -56.3 & 93.8 & 2.4 & 93.9 & 2.7 & 94 & 2.7 & 94 & 2.4 \\
\hline Z087 & 0.069 & 0.011 & 0.01 & 0.0003 & 0.0473 & 0.0064 & 67 & 10 & 64.2 & 1.9 & 100 & 250 & 35.8 & 64.2 & 1.9 & 63.9 & 2 & 64 & 2 & 64.1 & 2 \\
\hline 2088 & 0.0356 & 0.0045 & 0.00519 & 0.00016 & 0.0509 & 0.0065 & 36.4 & 4.8 & 33.4 & 1 & 150 & 220 & 77.7 & 33.4 & 1.0 & 33.2 & 1 & 33.2 & 1 & 33.4 & 1 \\
\hline Z089 & 0.052 & 0.0046 & 0.00853 & 0.00052 & 0.0451 & 0.0035 & 51.3 & 4.4 & 54.7 & 3.3 & -20 & 140 & 373.5 & 54.7 & 3.3 & 54.9 & 3.4 & 54.9 & 3.4 & 53.6 & 3.7 \\
\hline Z090 & 0.143 & 0.011 & 0.023 & 0.0014 & 0.0456 & 0.0025 & 135.5 & 9.4 & 146.4 & 8.6 & 0 & 100 & \#DIV/o! & 146.4 & 8.6 & 146.5 & 8.8 & 147.1 & 8.8 & 137 & 12 \\
\hline 2091 & 0.0442 & 0.0065 & 0.00712 & 0.00037 & 0.0466 & 0.0071 & 43.7 & 6.3 & 45.7 & 2.4 & -10 & 250 & 557.0 & 45.7 & 2.4 & 45.8 & 2.6 & 45.8 & 2.6 & 45.5 & 2.5 \\
\hline Z092 & 0.0533 & 0.0019 & 0.00861 & 0.00018 & 0.045 & 0.0015 & 52.7 & 1.9 & 55.2 & 1.1 & -25 & 65 & 320.8 & 55.2 & 1.1 & 55.3 & 1.2 & 55.4 & 1.2 & 51.4 & 3.1 \\
\hline 2093 & 0.062 & 0.011 & 0.00886 & 0.00038 & 0.0506 & 0.009 & 60 & 10 & 56.9 & 2.4 & 90 & 300 & 36.8 & 56.9 & 2.4 & 56.6 & 2.5 & 56.6 & 2.5 & 56.9 & 2.4 \\
\hline Z094 & 1.002 & 0.04 & 0.1181 & 0.0033 & 0.0614 & 0.0016 & 702 & 20 & 719 & 19 & 641 & 54 & -12.2 & discordant & discordant & 690 & 18 & 718 & 19 & 596 & 39 \\
\hline 2095 & 0.0733 & 0.0068 & 0.0111 & 0.00035 & 0.0484 & 0.0044 & 71.5 & 6.5 & 71.2 & 2.3 & 110 & 170 & 35.3 & 71.2 & 2.3 & 71 & 2.3 & 71.1 & 2.3 & 69.8 & 3.7 \\
\hline 2096 & 0.0578 & 0.0053 & 0.00987 & 0.00028 & 0.0427 & 0.0039 & 56.9 & 5.1 & 63.3 & 1.8 & -110 & 160 & 157.5 & 63.3 & 1.8 & 63.6 & 1.9 & 63.7 & 1.9 & 63.2 & 1.8 \\
\hline Z097 & 0.0822 & 0.0051 & 0.01323 & 0.00063 & 0.046 & 0.002 & 80.1 & 4.8 & 84.7 & 4 & 22 & 85 & -285.0 & 84.7 & 4.0 & 84.7 & 4 & 84.8 & 4 & 83.7 & 4.5 \\
\hline 2098 & 0.0789 & 0.0063 & 0.01094 & 0.00021 & 0.052 & 0.0037 & 76.9 & 5.8 & 70.2 & 1.3 & 230 & 130 & 69.5 & 70.2 & 1.3 & 69.6 & 1.2 & 69.8 & 1.3 & 67.8 & 2.9 \\
\hline 2099 & 0.0484 & 0.0047 & 0.00686 & 0.00016 & 0.052 & 0.0048 & 47.8 & 4.5 & 44.1 & 1 & 240 & 170 & 81.6 & 44.1 & 1.0 & 43.9 & 1.1 & 44 & 1.1 & 44.1 & 1.3 \\
\hline Z100 & 0.09 & 0.023 & 0.01586 & 0.00048 & 0.041 & 0.01 & 84 & 21 & 101.4 & 3.1 & -260 & 360 & 139.0 & 101.4 & 3.1 & 102.2 & 3.4 & 102.3 & 3.4 & 101.2 & 3.1 \\
\hline Z101 & 0.0236 & 0.0024 & 0.003957 & 0.000078 & 0.0431 & 0.0041 & 23.6 & 2.4 & 25.46 & 0.5 & -100 & 160 & 125.5 & 25.5 & 0.5 & 25.56 & 0.5 & 25.56 & 0.5 & 25.37 & 0.53 \\
\hline Z102 & 0.0625 & 0.0037 & 0.00998 & 0.00027 & 0.0454 & 0.0025 & 61.5 & 3.6 & 64 & 1.7 & 0 & 100 & \#DIV/0! & 64.0 & 1.7 & 64.1 & 1.8 & 64.2 & 1.8 & 63.1 & 2.2 \\
\hline
\end{tabular}




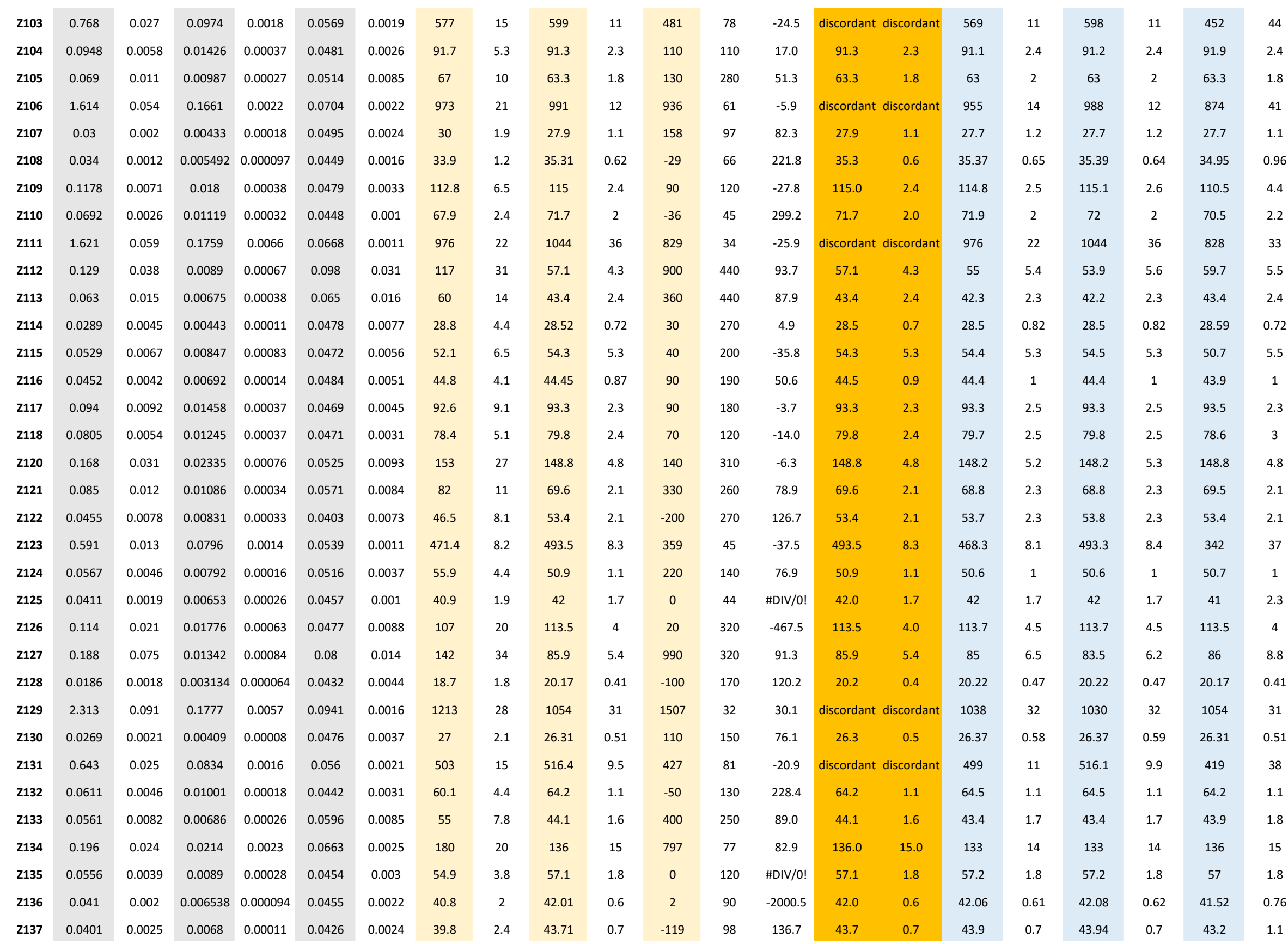




\begin{tabular}{|c|c|c|c|c|c|c|c|c|c|c|c|c|c|c|c|c|c|c|c|}
\hline 0.133 & 0.034 & 0.01803 & 0.00087 & 0.052 & 0.013 & 121 & 30 & 115.2 & 5.5 & 80 & 420 & -44.0 & 115.2 & 5.5 & 114.3 & 5.9 & 114.4 & 5.9 & 113.5 \\
\hline 0.367 & 0.052 & 0.0212 & 0.0026 & 0.121 & 0.0041 & 308 & 39 & 135 & 17 & 1954 & 63 & 93.1 & 135.0 & 17.0 & 123 & 15 & 122 & 15 & 135 \\
\hline 0.2272 & 0.0099 & 0.03369 & 0.00053 & 0.0488 & 0.0018 & 207.5 & 8.1 & 213.6 & 3.3 & 137 & 77 & -55.9 & 213.6 & 3.3 & 212 & 3.5 & 213.9 & 3.3 & 193 \\
\hline
\end{tabular}




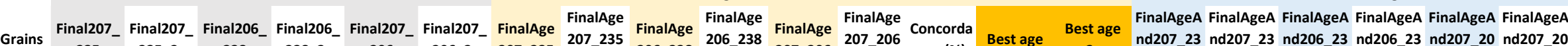

\begin{tabular}{|c|c|c|c|c|c|c|c|c|c|c|c|c|c|c|c|c|c|c|c|c|c|}
\hline Grains & 235 & 235_2s & 238 & 238_2s & 206 & 206_2s & 207_235 & $\begin{array}{c}207 \_235 \\
\ldots 2 s\end{array}$ & 206_238 & $\begin{array}{c}206 \_238 \\
\ldots 2 s\end{array}$ & 207_206 & $\begin{array}{c}207 \_206 \\
\ldots \text { 2s }\end{array}$ & nce (\%) & Best age & $2 s$ & $\begin{array}{c}\text { nd207_23 } \\
5\end{array}$ & $\begin{array}{c}\text { nd207_23 } \\
5 \_2 s\end{array}$ & $\begin{array}{c}3 \text { nd206_23 } \\
8\end{array}$ & $\begin{array}{c}\text { nd206_23 } \\
8 \_2 s\end{array}$ & $\begin{array}{c}3 \text { nd207_20 } \\
6\end{array}$ & $\begin{array}{c}\text { nd207_2 } \\
6 \_2 s\end{array}$ \\
\hline 2001 & 0.132 & 0.034 & 0.00821 & 0.0006 & 0.096 & 0.019 & 121 & 28 & 52.7 & 3.9 & 1320 & 410 & 96.0 & 52.7 & 3.9 & 49.6 & 3.9 & 47.9 & 4.1 & 55.7 & 5.5 \\
\hline 2002 & 0.0808 & 0.0081 & 0.00819 & 0.00028 & 0.0705 & 0.0062 & 78.5 & 7.6 & 52.6 & 1.8 & 820 & 180 & 93.6 & 52.6 & 1.8 & 51 & 1.6 & 51 & 1.6 & 52.6 & 1.8 \\
\hline 2003 & 0.0555 & 0.0036 & 0.00802 & 0.0003 & 0.05 & 0.0027 & 54.7 & 3.5 & 51.5 & 1.9 & 180 & 110 & 71.4 & 51.5 & 1.9 & 51.3 & 1.9 & 51.3 & 1.9 & 51.9 & 2.2 \\
\hline 2004 & 0.0706 & 0.0091 & 0.00847 & 0.0005 & 0.0631 & 0.0081 & 68.9 & 8.5 & 54.4 & 3.2 & 520 & 240 & 89.5 & 54.4 & 3.2 & 52.1 & 2.9 & 52.1 & 2.9 & 54.2 & 3.2 \\
\hline 2006 & 0.0952 & 0.0072 & 0.01513 & 0.00056 & 0.0473 & 0.0041 & 93.8 & 7.4 & 96.8 & 3.5 & 90 & 160 & -7.6 & 96.8 & 3.5 & 95.8 & 3.4 & 96.8 & 3.7 & 95.6 & 4.1 \\
\hline Z007 & 10.98 & 0.34 & 0.407 & 0.012 & 0.1961 & 0.0058 & 2516 & 29 & 2196 & 57 & 2783 & 49 & 21.1 & discordant & discordant & 2148 & 68 & 2076 & 71 & 2206 & 58 \\
\hline 2008 & 0.0536 & 0.0019 & 0.00787 & 0.00022 & 0.0499 & 0.002 & 53 & 1.8 & 50.6 & 1.4 & 181 & 85 & 72.0 & 50.6 & 1.4 & 50.4 & 1.5 & 50.4 & 1.5 & 50.1 & 1.5 \\
\hline 2009 & 0.1089 & 0.0099 & 0.01521 & 0.00075 & 0.0536 & 0.005 & 104.4 & 9.1 & 97.3 & 4.8 & 290 & 180 & 66.4 & 97.3 & 4.8 & 94.8 & 4.1 & 94.9 & 4.1 & 96 & 5.4 \\
\hline Z010 & 0.0716 & 0.009 & 0.01102 & 0.00045 & 0.0466 & 0.0056 & 69.8 & 8.4 & 70.6 & 2.9 & 60 & 210 & -17.7 & 70.6 & 2.9 & 70.7 & 3 & 70.7 & 3 & 70.6 & 2.9 \\
\hline 2011 & 0.0267 & 0.0036 & 0.00418 & 0.00026 & 0.0482 & 0.0073 & 26.7 & 3.5 & 26.9 & 1.7 & 130 & 270 & 79.3 & 26.9 & 1.7 & 26.8 & 1.8 & 26.8 & 1.8 & 26.5 & 1.7 \\
\hline 2012 & 0.228 & 0.041 & 0.01675 & 0.00074 & 0.096 & 0.015 & 202 & 33 & 107.1 & 4.7 & 1240 & 310 & 91.4 & 107.1 & 4.7 & 99.6 & 3.5 & 99.3 & 3.5 & 106.9 & 4.7 \\
\hline 2013 & 0.0987 & 0.0054 & 0.0152 & 0.00045 & 0.0477 & 0.0028 & 95.5 & 5 & 97.2 & 2.8 & 90 & 110 & -8.0 & 97.2 & 2.8 & 97.2 & 3 & 97.3 & 3 & 94.7 & 3.6 \\
\hline 2015 & 0.75 & 0.052 & 0.0931 & 0.0027 & 0.0602 & 0.0047 & 569 & 32 & 573 & 16 & 530 & 160 & -8.1 & discordant & discordant & 550 & 17 & 572 & 17 & 479 & 46 \\
\hline Z016 & 0.0489 & 0.0053 & 0.00687 & 0.00041 & 0.0513 & 0.0044 & 48.3 & 5.2 & 44.1 & 2.6 & 220 & 170 & 80.0 & 44.1 & 2.6 & 43.9 & 2.6 & 43.9 & 2.6 & 44.1 & 2.6 \\
\hline 2017 & 0.1647 & 0.0079 & 0.02423 & 0.00077 & 0.0497 & 0.0024 & 154.5 & 6.8 & 154.3 & 4.8 & 174 & 98 & 11.3 & 154.3 & 4.8 & 153.6 & 5 & 154.1 & 5.1 & 149.9 & 6.1 \\
\hline 2018 & 0.082 & 0.014 & 0.01025 & 0.00037 & 0.058 & 0.01 & 79 & 13 & 65.7 & 2.4 & 300 & 310 & 78.1 & 65.7 & 2.4 & 65.9 & 3.2 & 64.8 & 2.6 & 66.7 & 3 \\
\hline 2019 & 0.0585 & 0.0037 & 0.00899 & 0.00023 & 0.0476 & 0.0032 & 57.6 & 3.6 & 57.7 & 1.5 & 80 & 130 & 27.9 & 57.7 & 1.5 & 57.7 & 1.6 & 57.7 & 1.6 & 57.7 & 1.5 \\
\hline 2020 & 0.139 & 0.0042 & 0.02094 & 0.00051 & 0.0485 & 0.0013 & 132.1 & 3.7 & 133.6 & 3.2 & 121 & 57 & -10.4 & 133.6 & 3.2 & 133.1 & 3.3 & 133.7 & 3.3 & 127.4 & 6.3 \\
\hline 2021 & 0.093 & 0.029 & 0.01088 & 0.0006 & 0.063 & 0.02 & 87 & 23 & 69.7 & 3.8 & 250 & 360 & 72.1 & 69.7 & 3.8 & 66.5 & 5 & 66.5 & 5 & 71 & 5.8 \\
\hline 2022 & 0.124 & 0.01 & 0.0181 & 0.00062 & 0.0503 & 0.0043 & 117.8 & 9.1 & 115.7 & 4 & 190 & 160 & 39.1 & 115.7 & 4.0 & 115.4 & 4.2 & 115.5 & 4.2 & 115.6 & 4 \\
\hline 2023 & 0.0333 & 0.0044 & 0.00454 & 0.00012 & 0.0532 & 0.0066 & 33.2 & 4.3 & 29.21 & 0.8 & 280 & 230 & 89.6 & 29.2 & 0.8 & 28.87 & 0.79 & 28.87 & 0.79 & 29.5 & 0.87 \\
\hline 2024 & 0.0549 & 0.0055 & 0.00818 & 0.00031 & 0.0507 & 0.0053 & 54.1 & 5.3 & 52.5 & 2 & 180 & 200 & 70.8 & 52.5 & 2.0 & 51.9 & 2.3 & 51.9 & 2.3 & 52.5 & 2 \\
\hline Z025 & 0.137 & 0.024 & 0.01519 & 0.00069 & 0.065 & 0.012 & 128 & 21 & 97.1 & 4.4 & 550 & 330 & 82.3 & 97.1 & 4.4 & 94.3 & 5.2 & 94.3 & 5.2 & 97.1 & 4.4 \\
\hline 2026 & 0.149 & 0.058 & 0.01675 & 0.00056 & 0.066 & 0.026 & 114 & 19 & 107.1 & 3.6 & 180 & 270 & 40.5 & 107.1 & 3.6 & 106.1 & 4 & 105.1 & 4.8 & 107.1 & 3.7 \\
\hline Z027 & 0.121 & 0.015 & 0.01656 & 0.00073 & 0.053 & 0.0062 & 115 & 14 & 105.8 & 4.6 & 280 & 230 & 62.2 & 105.8 & 4.6 & 104.8 & 4.8 & 104.9 & 4.8 & 107.3 & 5.5 \\
\hline Z028 & 1.294 & 0.05 & 0.1389 & 0.0041 & 0.0683 & 0.0028 & 845 & 21 & 838 & 23 & 870 & 81 & 3.7 & 838.0 & 23.0 & 801 & 19 & 834 & 24 & 717 & 46 \\
\hline 2029 & 0.643 & 0.025 & 0.083 & 0.0024 & 0.0578 & 0.0024 & 507 & 17 & 514 & 14 & 494 & 88 & -4.0 & 514.0 & 14.0 & 494 & 15 & 512 & 15 & 411 & 45 \\
\hline Z030 & 0.109 & 0.015 & 0.01465 & 0.00039 & 0.0547 & 0.0077 & 104 & 14 & 93.8 & 2.5 & 270 & 260 & 65.3 & 93.8 & 2.5 & 93 & 2.8 & 93 & 2.8 & 93.6 & 2.5 \\
\hline Z031 & 0.0681 & 0.0034 & 0.01026 & 0.00032 & 0.0486 & 0.0024 & 66.8 & 3.2 & 65.8 & 2.1 & 150 & 110 & 56.1 & 65.8 & 2.1 & 65.6 & 2.1 & 65.7 & 2.1 & 63.2 & 3.3 \\
\hline Z032 & 0.0503 & 0.0043 & 0.00676 & 0.00016 & 0.0541 & 0.0048 & 49.8 & 4.1 & 43.5 & 1 & 310 & 180 & 86.0 & 43.5 & 1.0 & 43.3 & 1.2 & 43.3 & 1.3 & 43.8 & 1.4 \\
\hline
\end{tabular}




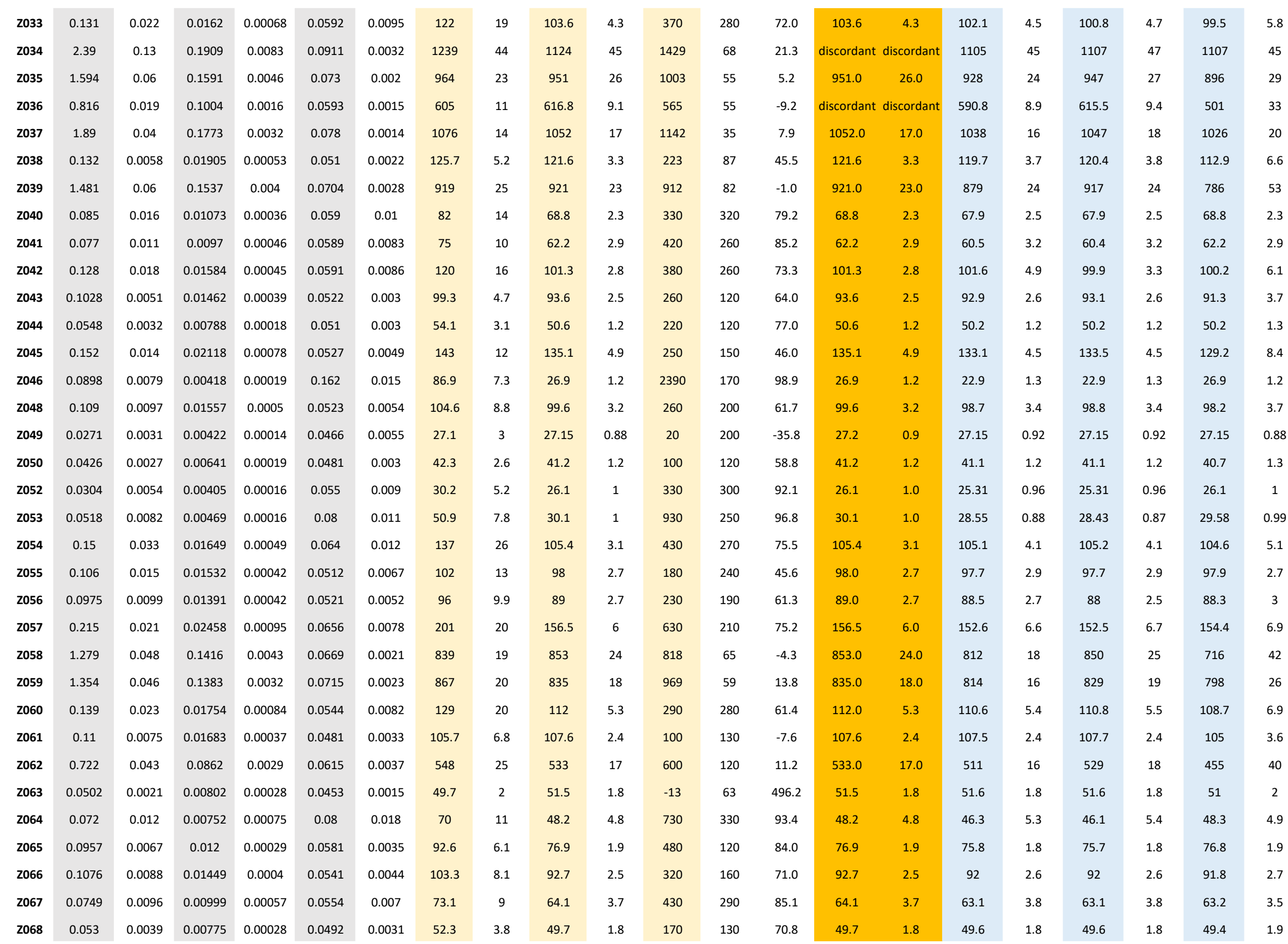




\begin{tabular}{|c|c|c|c|c|c|c|c|c|c|c|c|c|c|c|c|c|c|c|c|c|}
\hline Z069 & 0.047 & 0.0024 & 0.00706 & 0.00018 & 0.0485 & 0.0021 & 46.6 & 2.3 & 45.3 & 1.2 & 118 & 86 & 61.6 & 45.3 & 1.2 & 45.2 & 1.2 & 45.2 & 1.2 & 45.2 \\
\hline Zo70 & 0.067 & 0.0051 & 0.01002 & 0.00036 & 0.049 & 0.0037 & 65.7 & 4.9 & 64.3 & 2.3 & 140 & 150 & 54.1 & 64.3 & 2.3 & 64.1 & 2.4 & 64.2 & 2.4 & 63.3 \\
\hline $\mathrm{z} 071$ & 0.1716 & 0.0097 & 0.02354 & 0.00076 & 0.0519 & 0.003 & 162.6 & 9.4 & 150 & 4.8 & 320 & 140 & 53.1 & 150.0 & 4.8 & 148.5 & 5 & 148.9 & 5 & 146.3 \\
\hline $\mathrm{z} 072$ & 0.1009 & 0.0081 & 0.01362 & 0.00036 & 0.0541 & 0.0043 & 97.2 & 7.5 & 87.2 & 2.3 & 320 & 160 & 72.8 & 87.2 & 2.3 & 86.5 & 2.4 & 86.5 & 2.4 & 87 \\
\hline $\mathrm{z} 073$ & 0.62 & 0.026 & 0.0764 & 0.0013 & 0.0591 & 0.0026 & 489 & 16 & 474.8 & 7.7 & 543 & 96 & 12.6 & 474.8 & 7.7 & 464.5 & 9.1 & 472.8 & 8.2 & 441 \\
\hline $\mathrm{Z} 074$ & 4.23 & 0.14 & 0.2873 & 0.0087 & 0.1083 & 0.0023 & 1682 & 29 & 1626 & 44 & 1764 & 40 & 7.8 & 1764.0 & 40.0 & 1605 & 42 & 1612 & 47 & 1599 \\
\hline $\mathrm{Z} 075$ & 0.068 & 0.015 & 0.00677 & 0.00081 & 0.068 & 0.019 & 65 & 14 & 43.5 & 5.2 & 430 & 540 & 89.9 & 43.5 & 5.2 & 42.1 & 5.3 & 42.1 & 5.3 & 43.5 \\
\hline Z076 & 10.86 & 0.73 & 0.365 & 0.022 & 0.2148 & 0.0049 & 2473 & 92 & 1990 & 110 & 2936 & 39 & 32.2 & discordant & discordant & 1900 & 110 & 1820 & 110 & 1990 \\
\hline Z077 & 0.134 & 0.028 & 0.01582 & 0.0008 & 0.059 & 0.011 & 125 & 25 & 101.1 & 5.1 & 440 & 380 & 77.0 & 101.1 & 5.1 & 99.5 & 5.6 & 99.4 & 5.6 & 101.1 \\
\hline zo78 & 1.036 & 0.082 & 0.1016 & 0.0039 & 0.0733 & 0.0038 & 711 & 40 & 623 & 23 & 970 & 110 & 35.8 & discordant & discordant & 607 & 24 & 613 & 22 & 603 \\
\hline zo79 & 0.163 & 0.01 & 0.0236 & 0.0009 & 0.0502 & 0.0025 & 152.6 & 8.8 & 150.3 & 5.7 & 190 & 100 & 20.9 & 150.3 & 5.7 & 149.7 & 5.7 & 150.1 & 5.7 & 145.5 \\
\hline $\mathrm{Z} 080$ & 2.023 & 0.085 & 0.1888 & 0.0042 & 0.0784 & 0.0025 & 1118 & 29 & 1114 & 23 & 1142 & 62 & 2.5 & 1114.0 & 23.0 & 1085 & 22 & 1109 & 23 & 1046 \\
\hline $\mathrm{Z} 081$ & 0.065 & 0.007 & 0.00955 & 0.00032 & 0.0499 & 0.005 & 63.7 & 6.6 & 61.2 & 2.1 & 150 & 190 & 59.2 & 61.2 & 2.1 & 61 & 2.1 & 61 & 2.1 & 61 \\
\hline zo82 & 0.119 & 0.016 & 0.01418 & 0.00062 & 0.0605 & 0.0074 & 113 & 14 & 90.8 & 4 & 500 & 250 & 81.8 & 90.8 & 4.0 & 89.4 & 4.2 & 89.4 & 4.2 & 88.4 \\
\hline $\mathrm{z} 083$ & 4.58 & 0.15 & 0.3084 & 0.0098 & 0.1084 & 0.0023 & 1741 & 28 & 1731 & 48 & 1776 & 36 & 2.5 & 1776.0 & 36.0 & 1690 & 38 & 1721 & 51 & 1661 \\
\hline zo84 & 1.41 & 0.15 & 0.1307 & 0.0049 & 0.0772 & 0.0063 & 875 & 53 & 791 & 28 & 1100 & 160 & 28.1 & discordant & discordant & 755 & 23 & 774 & 27 & 726 \\
\hline $\mathrm{Z} 085$ & 0.1 & 0.013 & 0.01067 & 0.00039 & 0.0684 & 0.0085 & 95 & 12 & 68.4 & 2.5 & 690 & 250 & 90.1 & 68.4 & 2.5 & 66.6 & 2.6 & 66.6 & 2.6 & 68.2 \\
\hline Z086 & 1.776 & 0.039 & 0.1655 & 0.0031 & 0.0782 & 0.0013 & 1035 & 14 & 987 & 17 & 1148 & 32 & 14.0 & 987.0 & 17.0 & 982 & 18 & 980 & 18 & 986 \\
\hline Z087 & 0.0444 & 0.0028 & 0.00714 & 0.00032 & 0.0465 & 0.003 & 44.1 & 2.7 & 45.9 & 2 & 40 & 120 & -14.8 & 45.9 & 2.0 & 45.9 & 2.1 & 46 & 2.1 & 45.8 \\
\hline Z088 & 3.32 & 0.11 & 0.2488 & 0.0077 & 0.0985 & 0.0029 & 1483 & 25 & 1431 & 40 & 1582 & 55 & 9.5 & 1582.0 & 55.0 & 1395 & 32 & 1415 & 42 & 1371 \\
\hline Z089 & 0.096 & 0.011 & 0.01432 & 0.00061 & 0.0498 & 0.0059 & 93 & 10 & 91.6 & 3.9 & 170 & 220 & 46.1 & 91.6 & 3.9 & 91.3 & 4.1 & 91.4 & 4.2 & 91.9 \\
\hline Z090 & 0.1805 & 0.0062 & 0.02568 & 0.0005 & 0.0512 & 0.0014 & 168.4 & 5.3 & 163.4 & 3.2 & 238 & 61 & 31.3 & 163.4 & 3.2 & 162 & 3.3 & 163 & 3.2 & 151.8 \\
\hline Z091 & 0.0369 & 0.0076 & 0.00555 & 0.0003 & 0.05 & 0.011 & 36.5 & 7.3 & 35.7 & 1.9 & 100 & 360 & 64.3 & 35.7 & 1.9 & 35.4 & 2.2 & 35.4 & 2.2 & 35.7 \\
\hline Z093 & 0.1157 & 0.0059 & 0.01681 & 0.0005 & 0.0499 & 0.0024 & 111 & 5.3 & 107.4 & 3.2 & 175 & 96 & 38.6 & 107.4 & 3.2 & 106.6 & 3.2 & 107.1 & 3.3 & 103.7 \\
\hline Z094 & 0.108 & 0.012 & 0.01498 & 0.00058 & 0.055 & 0.0066 & 104 & 11 & 95.9 & 3.7 & 320 & 230 & 70.0 & 95.9 & 3.7 & 95 & 3.8 & 95.1 & 3.8 & 95.8 \\
\hline Z095 & 0.13 & 0.018 & 0.0166 & 0.0011 & 0.0581 & 0.0074 & 123 & 16 & 106.3 & 7.2 & 430 & 260 & 75.3 & 106.3 & 7.2 & 104.2 & 7.7 & 104.2 & 7.7 & 106.3 \\
\hline Z096 & 0.084 & 0.012 & 0.0133 & 0.00048 & 0.0467 & 0.0066 & 81 & 11 & 85.2 & 3.1 & 10 & 240 & -752.0 & 85.2 & 3.1 & 85.2 & 3.4 & 85.3 & 3.4 & 84.5 \\
\hline Zo97 & 1.58 & 0.071 & 0.1623 & 0.005 & 0.071 & 0.0025 & 958 & 27 & 969 & 28 & 937 & 71 & -3.4 & 969.0 & 28.0 & 925 & 23 & 965 & 28 & 837 \\
\hline Z099 & 0.407 & 0.021 & 0.0566 & 0.0024 & 0.0522 & 0.0025 & 346 & 15 & 355 & 15 & 280 & 100 & -26.8 & 355.0 & 15.0 & 346 & 14 & 355 & 15 & 301 \\
\hline Z100 & 0.169 & 0.057 & 0.0109 & 0.00072 & 0.112 & 0.036 & 152 & 47 & 69.9 & 4.6 & 1480 & 720 & 95.3 & 69.9 & 4.6 & 64.7 & 5.3 & 64.6 & 5.4 & 70 \\
\hline Z101 & 0.0429 & 0.0027 & 0.00671 & 0.0002 & 0.0468 & 0.0028 & 42.7 & 2.6 & 43.1 & 1.3 & 50 & 110 & 13.8 & 43.1 & 1.3 & 43.1 & 1.3 & 43.1 & 1.3 & 43.1 \\
\hline Z102 & 1.225 & 0.051 & 0.1235 & 0.0041 & 0.0721 & 0.0029 & 809 & 23 & 750 & 23 & 962 & 84 & 22.0 & discordant & discordant & 733 & 21 & 742 & 24 & 703 \\
\hline $\mathrm{Z} 103$ & 0.0664 & 0.0045 & 0.01022 & 0.00045 & 0.0477 & 0.003 & 65.2 & 4.2 & 65.5 & 2.9 & 120 & 130 & 45.4 & 65.5 & 2.9 & 65.4 & 3 & 65.5 & 3 & 64 \\
\hline Z104 & 0.854 & 0.028 & 0.1042 & 0.0023 & 0.0598 & 0.0018 & 625 & 16 & 639 & 14 & 580 & 67 & -10.2 & discordant & discordant & 613 & 13 & 637 & 14 & 530 \\
\hline
\end{tabular}




\begin{tabular}{|c|c|c|c|c|c|c|c|c|c|c|c|c|c|c|c|c|c|c|c|c|}
\hline Z105 & 0.057 & 0.0071 & 0.00837 & 0.00028 & 0.0494 & 0.0059 & 56 & 6.8 & 53.7 & 1.8 & 160 & 230 & 66.4 & 53.7 & 1.8 & 53.5 & 1.8 & 53.5 & 1.8 & 53.7 \\
\hline Z106 & 0.104 & 0.013 & 0.01675 & 0.00085 & 0.0463 & 0.0062 & 102 & 13 & 107 & 5.4 & 50 & 240 & -114.0 & 107.0 & 5.4 & 107.2 & 5.8 & 107.3 & 5.8 & 106.4 \\
\hline Z107 & 0.2 & 0.023 & 0.0089 & 0.0005 & 0.171 & 0.022 & 184 & 19 & 57.1 & 3.2 & 2530 & 240 & 97.7 & 57.1 & 3.2 & 49 & 3.6 & 47.7 & 3.7 & 60.4 \\
\hline Z108 & 0.114 & 0.01 & 0.01763 & 0.0007 & 0.0481 & 0.0047 & 109 & 9.1 & 112.6 & 4.4 & 120 & 180 & 6.2 & 112.6 & 4.4 & 112.5 & 4.8 & 112.7 & 4.8 & 112.6 \\
\hline Z109 & 0.087 & 0.018 & 0.00817 & 0.00026 & 0.071 & 0.012 & 83 & 16 & 52.5 & 1.6 & 690 & 310 & 92.4 & 52.5 & 1.6 & 50.1 & 1.7 & 50 & 1.7 & 52.5 \\
\hline Z110 & 2.082 & 0.095 & 0.1887 & 0.0061 & 0.0807 & 0.0033 & 1137 & 31 & 1113 & 33 & 1186 & 81 & 6.2 & 1113.0 & 33.0 & 1070 & 29 & 1104 & 35 & 1006 \\
\hline Z111 & 0.963 & 0.057 & 0.0784 & 0.0024 & 0.0905 & 0.0059 & 680 & 29 & 486 & 14 & 1370 & 130 & 64.5 & 486.0 & 14.0 & 469 & 15 & 467 & 16 & 481 \\
\hline Z112 & 0.199 & 0.048 & 0.01396 & 0.00094 & 0.091 & 0.016 & 175 & 36 & 89.3 & 5.9 & 1130 & 330 & 92.1 & 89.3 & 5.9 & 83.6 & 5.5 & 83.4 & 5.5 & 88.7 \\
\hline Z113 & 0.101 & 0.016 & 0.01401 & 0.00059 & 0.0535 & 0.0088 & 97 & 15 & 89.7 & 3.8 & 260 & 320 & 65.5 & 89.7 & 3.8 & 89.1 & 4.2 & 89.2 & 4.2 & 88 \\
\hline Z114 & 0.0303 & 0.0024 & 0.0046 & 0.00011 & 0.0481 & 0.0037 & 30.3 & 2.3 & 29.62 & 0.69 & 100 & 150 & 70.4 & 29.6 & 0.7 & 29.4 & 0.66 & 29.41 & 0.66 & 29.64 \\
\hline Z116 & 0.185 & 0.015 & 0.00496 & 0.00026 & 0.276 & 0.021 & 171 & 13 & 31.9 & 1.7 & 3270 & 130 & 99.0 & 31.9 & 1.7 & 22.4 & 1.5 & 22.3 & 1.5 & 31.9 \\
\hline Z117 & 0.649 & 0.056 & 0.0839 & 0.0037 & 0.058 & 0.0056 & 503 & 34 & 519 & 22 & 510 & 220 & -1.8 & 519.0 & 22.0 & 501 & 22 & 516 & 23 & 439 \\
\hline Z118 & 0.0534 & 0.0047 & 0.00804 & 0.00029 & 0.0483 & 0.004 & 52.7 & 4.5 & 51.6 & 1.9 & 140 & 160 & 63.1 & 51.6 & 1.9 & 51.4 & 1.9 & 51.5 & 1.9 & 51.2 \\
\hline Z119 & 0.065 & 0.013 & 0.00807 & 0.00028 & 0.0514 & 0.005 & 63 & 12 & 51.8 & 1.8 & 300 & 220 & 82.7 & 51.8 & 1.8 & 51.3 & 1.8 & 51.3 & 1.8 & 51.7 \\
\hline Z120 & 0.18 & 0.019 & 0.0073 & 0.00062 & 0.192 & 0.026 & 166 & 16 & 46.9 & 4 & 2550 & 250 & 98.2 & 46.9 & 4.0 & 39 & 4.3 & 38.9 & 4.3 & 46.9 \\
\hline Z121 & 0.0633 & 0.0058 & 0.00919 & 0.0003 & 0.0504 & 0.0043 & 62.1 & 5.6 & 59 & 1.9 & 230 & 180 & 74.3 & 59.0 & 1.9 & 58.6 & 1.9 & 58.6 & 1.9 & 59 \\
\hline Z122 & 3.33 & 0.2 & 0.252 & 0.01 & 0.0955 & 0.0032 & 1474 & 48 & 1448 & 53 & 1521 & 63 & 4.8 & 1521.0 & 63.0 & 1417 & 49 & 1438 & 55 & 1392 \\
\hline Z123 & 0.086 & 0.022 & 0.01416 & 0.00065 & 0.044 & 0.011 & 81 & 20 & 90.6 & 4.1 & -170 & 360 & 153.3 & 90.6 & 4.1 & 90.5 & 4.5 & 91.3 & 4.4 & 88.2 \\
\hline Z125 & 0.1725 & 0.0074 & 0.02254 & 0.0009 & 0.0552 & 0.002 & 161.3 & 6.5 & 143.7 & 5.7 & 412 & 83 & 65.1 & 143.7 & 5.7 & 142.1 & 5.7 & 142.5 & 5.8 & 141 \\
\hline Z126 & 1.447 & 0.052 & 0.1491 & 0.0041 & 0.0719 & 0.0025 & 911 & 20 & 895 & 23 & 964 & 70 & 7.2 & 895.0 & 23.0 & 862 & 18 & 886 & 23 & 813 \\
\hline Z127 & 0.0759 & 0.0059 & 0.00702 & 0.00031 & 0.0797 & 0.0061 & 74.1 & 5.6 & 45.1 & 2 & 1080 & 170 & 95.8 & 45.1 & 2.0 & 43.3 & 2 & 43.3 & 2 & 45.1 \\
\hline Z128 & 0.0731 & 0.0067 & 0.01036 & 0.00043 & 0.0518 & 0.0046 & 71.4 & 6.3 & 66.4 & 2.7 & 220 & 160 & 69.8 & 66.4 & 2.7 & 66 & 2.8 & 66.1 & 2.8 & 65.9 \\
\hline
\end{tabular}


U-Pb ages uncorrected for common lead

Ratios

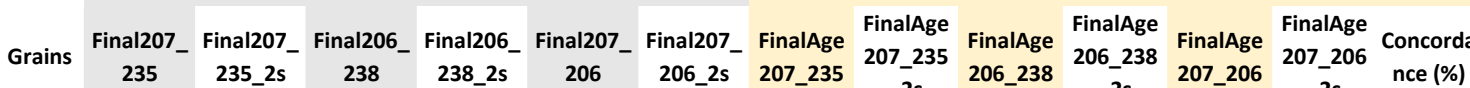

\begin{tabular}{|c|c|c|c|c|c|c|c|c|c|c|c|c|c|c|c|c|c|c|c|c|c|}
\hline Grains & $\begin{array}{l}\text { Finalzo'- } \\
235\end{array}$ & $235 \_2 s$ & 238 & 238_2s & 206 & 206_2s & $\begin{array}{l}\text { Finalage } \\
\text { 207_235 }\end{array}$ & $\begin{array}{c}207 \_235 \\
\text { 2s }\end{array}$ & $\begin{array}{l}\text { FinalAge } \\
\text { 206_238 }\end{array}$ & $\begin{array}{c}206 \_238 \\
25\end{array}$ & $\begin{array}{l}\text { FnalAge } \\
207 \_206\end{array}$ & $\begin{array}{c}\text { 207_206 } \\
\text { _2s }\end{array}$ & $\begin{array}{l}\text { Concorra } \\
\text { nce (\%) }\end{array}$ & Best age & $\begin{array}{c}\text { Best age } \\
2 s\end{array}$ & $\begin{array}{c}\text { nd207_23 } \\
5\end{array}$ & $\begin{array}{c}\text { nd207_23 } \\
5 \_2 s\end{array}$ & $\begin{array}{c}3 \text { nd206_23 } \\
8\end{array}$ & $\begin{array}{c}\text { nd206_23 } \\
8 \_2 s\end{array}$ & $\begin{array}{c}\text { nd207_20 } \\
6\end{array}$ & $\begin{array}{c}\text { nd207_20 } \\
6 \_2 s \\
\end{array}$ \\
\hline Z001 & 0.0992 & 0.0086 & 0.01491 & 0.00066 & 0.0482 & 0.0039 & 95.7 & 7.9 & 95.4 & 4.2 & 100 & 150 & 4.6 & 95.4 & 4.2 & 95.3 & 4.3 & 95.4 & 4.3 & 94.8 & 4.7 \\
\hline Z002 & 0.237 & 0.05 & 0.01401 & 0.00052 & 0.119 & 0.02 & 216 & 40 & 89.6 & 3.3 & 1620 & 270 & 94.5 & 89.6 & 3.3 & 83.2 & 3.4 & 82.9 & 3.4 & 89.6 & 3.4 \\
\hline 2003 & 0.1092 & 0.0061 & 0.01604 & 0.00039 & 0.049 & 0.0026 & 105.1 & 5.5 & 102.6 & 2.5 & 140 & 100 & 26.7 & 102.6 & 2.5 & 102.3 & 2.6 & 102.4 & 2.6 & 102.7 & 2.5 \\
\hline 2005 & 0.0699 & 0.0057 & 0.01049 & 0.00022 & 0.048 & 0.0039 & 68.5 & 5.4 & 67.3 & 1.4 & 90 & 150 & 25.2 & 67.3 & 1.4 & 67.2 & 1.5 & 67.2 & 1.5 & 66.4 & 1.6 \\
\hline 2006 & 0.102 & 0.0097 & 0.01395 & 0.00038 & 0.0528 & 0.0048 & 98.4 & 8.9 & 89.3 & 2.4 & 300 & 180 & 70.2 & 89.3 & 2.4 & 88.7 & 2.5 & 88.7 & 2.5 & 89.3 & 2.4 \\
\hline Z007 & 0.0645 & 0.0029 & 0.00947 & 0.00016 & 0.049 & 0.002 & 63.4 & 2.7 & 60.8 & 1 & 142 & 83 & 57.2 & 60.8 & 1.0 & 60.58 & 0.98 & 60.56 & 0.98 & 60.5 & 1.1 \\
\hline 2009 & 0.102 & 0.0063 & 0.0158 & 0.0004 & 0.0466 & 0.0027 & 98.4 & 5.8 & 101 & 2.6 & 40 & 110 & -152.5 & 101.0 & 2.6 & 101 & 2.6 & 101.2 & 2.6 & 98.9 & 3.9 \\
\hline 2010 & 1.057 & 0.042 & 0.1117 & 0.0016 & 0.0687 & 0.0027 & 731 & 21 & 682.4 & 9.1 & 872 & 83 & 21.7 & discordant & discordant & 670 & 10 & 676.5 & 9.9 & 661 & 17 \\
\hline 2011 & 0.0831 & 0.0082 & 0.01374 & 0.00032 & 0.0439 & 0.0043 & 80.7 & 7.7 & 88 & 2 & -70 & 170 & 225.7 & 88.0 & 2.0 & 88.2 & 2.2 & 88.4 & 2.2 & 87 & 3.2 \\
\hline Z012 & 0.0869 & 0.0065 & 0.01323 & 0.00027 & 0.0479 & 0.0039 & 84.4 & 6 & 84.7 & 1.7 & 90 & 150 & 5.9 & 84.7 & 1.7 & 84.7 & 1.9 & 84.7 & 2 & 84.8 & 1.8 \\
\hline 2013 & 0.0937 & 0.0085 & 0.01382 & 0.00037 & 0.0482 & 0.0042 & 90.6 & 7.9 & 88.5 & 2.3 & 130 & 170 & 31.9 & 88.5 & 2.3 & 88.2 & 2.4 & 88.3 & 2.4 & 86.1 & 3.6 \\
\hline Z014 & 0.0985 & 0.0078 & 0.01475 & 0.00028 & 0.0484 & 0.0041 & 95.1 & 7.2 & 94.4 & 1.8 & 110 & 160 & 14.2 & 94.4 & 1.8 & 94.1 & 1.9 & 94.3 & 1.9 & 92.8 & 3.3 \\
\hline 2015 & 0.121 & 0.0095 & 0.01934 & 0.00036 & 0.0465 & 0.004 & 115.5 & 8.6 & 123.5 & 2.3 & 40 & 150 & -208.8 & 123.5 & 2.3 & 123.6 & 2.6 & 123.8 & 2.6 & 123.6 & 2.4 \\
\hline Z016 & 0.079 & 0.013 & 0.01309 & 0.00042 & 0.0454 & 0.0083 & 79 & 14 & 83.8 & 2.7 & -70 & 280 & 219.7 & 83.8 & 2.7 & 84 & 2.8 & 84.1 & 2.8 & 83.8 & 2.6 \\
\hline Z017 & 0.0928 & 0.0063 & 0.01459 & 0.00032 & 0.0465 & 0.0034 & 89.9 & 5.8 & 93.4 & 2 & 40 & 140 & -133.5 & 93.4 & 2.0 & 93.4 & 2.2 & 93.6 & 2.2 & 92.4 & 2.6 \\
\hline Z018 & 0.084 & 0.01 & 0.01382 & 0.00028 & 0.044 & 0.0055 & 81.7 & 9.7 & 88.5 & 1.8 & -70 & 210 & 226.4 & 88.5 & 1.8 & 88.8 & 1.8 & 88.8 & 1.8 & 88.8 & 2 \\
\hline 2019 & 0.0827 & 0.0074 & 0.01329 & 0.0003 & 0.0459 & 0.0042 & 80.4 & 6.9 & 85.1 & 1.9 & 10 & 160 & -751.0 & 85.1 & 1.9 & 85.3 & 1.9 & 85.3 & 1.9 & 85.1 & 1.9 \\
\hline Z021 & 0.117 & 0.029 & 0.01477 & 0.00058 & 0.058 & 0.015 & 108 & 26 & 94.5 & 3.7 & 200 & 440 & 52.8 & 94.5 & 3.7 & 93.4 & 4.2 & 93.4 & 4.2 & 94.3 & 3.7 \\
\hline Z022 & 0.1029 & 0.0095 & 0.01512 & 0.00036 & 0.0494 & 0.0045 & 99 & 8.8 & 96.8 & 2.3 & 150 & 170 & 35.5 & 96.8 & 2.3 & 96.6 & 2.4 & 96.6 & 2.4 & 96.5 & 2.3 \\
\hline Z023 & 0.1037 & 0.0072 & 0.0153 & 0.00035 & 0.0495 & 0.0036 & 99.9 & 6.7 & 97.9 & 2.2 & 160 & 140 & 38.8 & 97.9 & 2.2 & 97.5 & 2.4 & 97.7 & 2.4 & 93.4 & 5.2 \\
\hline 2024 & 0.0971 & 0.0099 & 0.01458 & 0.0005 & 0.0479 & 0.0047 & 93.6 & 9.2 & 93.3 & 3.2 & 90 & 180 & -3.7 & 93.3 & 3.2 & 93.3 & 3.3 & 93.3 & 3.3 & 93 & 3.3 \\
\hline Z025 & 0.1129 & 0.0067 & 0.01616 & 0.00032 & 0.0518 & 0.0037 & 108.4 & 6.1 & 103.3 & 2 & 240 & 140 & 57.0 & 103.3 & 2.0 & 102.8 & 2.3 & 102.9 & 2.3 & 102.6 & 2.4 \\
\hline Z026 & 0.0723 & 0.009 & 0.0106 & 0.00027 & 0.05 & 0.0065 & 70.5 & 8.4 & 68 & 1.8 & 130 & 230 & 47.7 & 68.0 & 1.8 & 67.7 & 2 & 67.7 & 2 & 68.1 & 2.2 \\
\hline Z027 & 0.098 & 0.0063 & 0.01515 & 0.00025 & 0.0469 & 0.003 & 94.7 & 5.8 & 96.9 & 1.6 & 50 & 120 & -93.8 & 96.9 & 1.6 & 96.9 & 1.6 & 97 & 1.6 & 95.5 & 2.5 \\
\hline Z028 & 0.116 & 0.02 & 0.01452 & 0.00045 & 0.058 & 0.0095 & 109 & 17 & 92.9 & 2.9 & 380 & 280 & 75.6 & 92.9 & 2.9 & 91.1 & 2.9 & 91.2 & 2.9 & 93.1 & 3 \\
\hline 2029 & 0.088 & 0.018 & 0.01479 & 0.00056 & 0.0453 & 0.0096 & 84 & 16 & 94.6 & 3.6 & -30 & 350 & 415.3 & 94.6 & 3.6 & 94.6 & 4.3 & 94.7 & 4.4 & 94.2 & 3.5 \\
\hline 2030 & 0.1128 & 0.0075 & 0.01631 & 0.00052 & 0.0507 & 0.0031 & 108.3 & 6.9 & 104.3 & 3.3 & 220 & 130 & 52.6 & 104.3 & 3.3 & 103.4 & 3.2 & 103.7 & 3.2 & 103.3 & 3.8 \\
\hline 2031 & 0.082 & 0.012 & 0.01412 & 0.00041 & 0.0425 & 0.0066 & 79 & 11 & 90.4 & 2.6 & -90 & 260 & 200.4 & 90.4 & 2.6 & 90.8 & 3 & 90.8 & 3 & 90.3 & 2.7 \\
\hline 2032 & 0.301 & 0.08 & 0.01731 & 0.00063 & 0.115 & 0.027 & 247 & 58 & 110.6 & 4 & 1190 & 410 & 90.7 & 110.6 & 4.0 & 99.5 & 2.3 & 99.7 & 2.4 & 99.7 & 9 \\
\hline Z033 & 0.1051 & 0.0059 & 0.01439 & 0.00033 & 0.0526 & 0.003 & 101.3 & 5.4 & 92.1 & 2.1 & 290 & 120 & 68.2 & 92.1 & 2.1 & 91.5 & 2.1 & 91.6 & 2.1 & 92.5 & 2.4 \\
\hline
\end{tabular}

Corrected for common lead using Andersen's routine

IAgeA FinalAgeA FinalAgeA FinalAgeA FinalAgeA FinalAgeA $2 s$

\section{7} 1.6

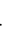




\begin{tabular}{|c|c|c|c|c|c|c|c|c|c|c|c|c|c|c|c|c|c|c|c|c|}
\hline Z034 & 0.093 & 0.015 & 0.0143 & 0.00041 & 0.048 & 0.0079 & 89 & 14 & 91.5 & 2.6 & 40 & 280 & -128.8 & 91.5 & 2.6 & 91.5 & 3 & 91.5 & 3 & 91.5 \\
\hline 2035 & 0.103 & 0.015 & 0.01593 & 0.00034 & 0.0472 & 0.0068 & 98 & 13 & 101.9 & 2.2 & 30 & 240 & -239.7 & 101.9 & 2.2 & 102 & 2.5 & 102 & 2.6 & 101.8 \\
\hline Z036 & 0.129 & 0.019 & 0.01649 & 0.00039 & 0.0583 & 0.0083 & 126 & 18 & 105.4 & 2.4 & 360 & 250 & 70.7 & 105.4 & 2.4 & 103.9 & 2.4 & 104 & 2.4 & 105.4 \\
\hline Z037 & 0.099 & 0.011 & 0.01506 & 0.0004 & 0.0483 & 0.0054 & 95.5 & 9.9 & 96.4 & 2.5 & 90 & 200 & -7.1 & 96.4 & 2.5 & 96.4 & 2.8 & 96.4 & 2.8 & 96.8 \\
\hline Z038 & 0.0993 & 0.0085 & 0.01518 & 0.00037 & 0.0479 & 0.0044 & 95.8 & 7.8 & 97.1 & 2.3 & 80 & 170 & -21.4 & 97.1 & 2.3 & 97 & 2.6 & 97.1 & 2.6 & 97.2 \\
\hline Z039 & 0.1057 & 0.0085 & 0.01511 & 0.00038 & 0.051 & 0.0042 & 101.7 & 7.9 & 96.7 & 2.4 & 210 & 160 & 54.0 & 96.7 & 2.4 & 96.1 & 2.5 & 96.3 & 2.5 & 95.3 \\
\hline Z040 & 0.1096 & 0.0085 & 0.01504 & 0.00034 & 0.053 & 0.0041 & 105.3 & 7.8 & 96.2 & 2.2 & 290 & 160 & 66.8 & 96.2 & 2.2 & 95.5 & 2.2 & 95.6 & 2.3 & 95 \\
\hline Z041 & 0.1006 & 0.0049 & 0.01514 & 0.00028 & 0.0483 & 0.0024 & 97.2 & 4.5 & 96.9 & 1.8 & 140 & 110 & 30.8 & 96.9 & 1.8 & 96.6 & 1.9 & 96.8 & 1.9 & 95.6 \\
\hline Z042 & 0.18 & 0.037 & 0.0158 & 0.00046 & 0.078 & 0.015 & 163 & 30 & 101.1 & 2.9 & 830 & 340 & 87.8 & 101.1 & 2.9 & 96.7 & 3.3 & 96.6 & 3.3 & 100.9 \\
\hline Z043 & 0.363 & 0.021 & 0.05122 & 0.00091 & 0.0518 & 0.003 & 314 & 15 & 322 & 5.6 & 250 & 120 & -28.8 & 322.0 & 5.6 & 315.7 & 6.9 & 322 & 6 & 270 \\
\hline Z044 & 0.096 & 0.011 & 0.01506 & 0.00029 & 0.048 & 0.0059 & 95 & 11 & 96.4 & 1.8 & 60 & 210 & -60.7 & 96.4 & 1.8 & 96.3 & 2.1 & 96.4 & 2.2 & 96.3 \\
\hline Z045 & 0.0956 & 0.0087 & 0.0148 & 0.00034 & 0.0469 & 0.0041 & 92.3 & 8 & 94.7 & 2.1 & 60 & 160 & -57.8 & 94.7 & 2.1 & 94.8 & 2.2 & 94.8 & 2.2 & 94.7 \\
\hline Z046 & 0.11 & 0.019 & 0.01499 & 0.00061 & 0.0539 & 0.009 & 104 & 17 & 95.9 & 3.9 & 220 & 300 & 56.4 & 95.9 & 3.9 & 95.1 & 4.1 & 95.2 & 4.2 & 95.5 \\
\hline Z047 & 0.174 & 0.03 & 0.01649 & 0.00048 & 0.079 & 0.013 & 160 & 25 & 105.4 & 3 & 930 & 320 & 88.7 & 105.4 & 3.0 & 101.7 & 3.2 & 101.6 & 3.2 & 105.5 \\
\hline Z048 & 0.103 & 0.019 & 0.0144 & 0.00055 & 0.0514 & 0.0098 & 97 & 17 & 92.2 & 3.5 & 170 & 330 & 45.8 & 92.2 & 3.5 & 91.7 & 4.1 & 91.7 & 4.1 & 92.2 \\
\hline Z049 & 0.124 & 0.02 & 0.01517 & 0.00041 & 0.06 & 0.01 & 117 & 17 & 97.1 & 2.6 & 450 & 290 & 78.4 & 97.1 & 2.6 & 95.3 & 3.4 & 95.2 & 3.4 & 97.1 \\
\hline Z050 & 0.111 & 0.013 & 0.01607 & 0.00039 & 0.0525 & 0.0068 & 109 & 12 & 102.8 & 2.5 & 210 & 230 & 51.0 & 102.8 & 2.5 & 102.3 & 3 & 102.3 & 3 & 102.8 \\
\hline Z051 & 0.116 & 0.014 & 0.01508 & 0.00034 & 0.0558 & 0.0065 & 110 & 12 & 96.5 & 2.1 & 340 & 230 & 71.6 & 96.5 & 2.1 & 95.5 & 2.3 & 95.5 & 2.3 & 96.3 \\
\hline Z052 & 0.104 & 0.011 & 0.01479 & 0.00041 & 0.0514 & 0.0058 & 99 & 10 & 94.7 & 2.6 & 200 & 210 & 52.7 & 94.7 & 2.6 & 94.3 & 2.9 & 94.3 & 2.9 & 94.6 \\
\hline Z053 & 0.0966 & 0.0075 & 0.01389 & 0.00026 & 0.0509 & 0.0042 & 93.3 & 7 & 88.9 & 1.6 & 240 & 170 & 63.0 & 88.9 & 1.6 & 88.5 & 1.9 & 88.5 & 1.9 & 88.5 \\
\hline Z054 & 0.095 & 0.012 & 0.01578 & 0.00044 & 0.0436 & 0.0055 & 91 & 12 & 100.9 & 2.8 & -90 & 210 & 212.1 & 100.9 & 2.8 & 101.3 & 2.9 & 101.5 & 2.9 & 99.4 \\
\hline Z055 & 0.1065 & 0.0095 & 0.01471 & 0.00033 & 0.0533 & 0.0053 & 102.3 & 8.7 & 94.1 & 2.1 & 280 & 190 & 66.4 & 94.1 & 2.1 & 93.5 & 2.4 & 93.6 & 2.4 & 94.3 \\
\hline Z056 & 0.1119 & 0.0098 & 0.01542 & 0.00037 & 0.0523 & 0.0039 & 107.2 & 8.8 & 98.7 & 2.4 & 260 & 150 & 62.0 & 98.7 & 2.4 & 97.9 & 2.3 & 98.1 & 2.3 & 97.2 \\
\hline Z057 & 0.1094 & 0.007 & 0.01503 & 0.00055 & 0.0534 & 0.0036 & 105.2 & 6.4 & 96.1 & 3.5 & 330 & 140 & 70.9 & 96.1 & 3.5 & 95.4 & 3.7 & 95.4 & 3.7 & 95.2 \\
\hline Z058 & 0.097 & 0.012 & 0.01687 & 0.00041 & 0.0417 & 0.0051 & 93 & 11 & 107.8 & 2.6 & -160 & 200 & 167.4 & 107.8 & 2.6 & 108.7 & 2.8 & 108.7 & 2.8 & 108.1 \\
\hline Z059 & 0.1041 & 0.0066 & 0.0153 & 0.00029 & 0.0487 & 0.0029 & 100.4 & 6 & 97.9 & 1.8 & 150 & 120 & 34.7 & 97.9 & 1.8 & 98.1 & 1.8 & 98.1 & 1.8 & 97.6 \\
\hline Z060 & 0.0988 & 0.0062 & 0.01513 & 0.00026 & 0.0473 & 0.0029 & 95.5 & 5.8 & 96.8 & 1.7 & 70 & 120 & -38.3 & 96.8 & 1.7 & 96.7 & 1.7 & 96.9 & 1.7 & 95.7 \\
\hline Z061 & 0.204 & 0.032 & 0.01583 & 0.00037 & 0.093 & 0.014 & 185 & 26 & 101.2 & 2.3 & 1180 & 300 & 91.4 & 101.2 & 2.3 & 95.5 & 2.9 & 95.4 & 2.9 & 101.2 \\
\hline Z062 & 0.1115 & 0.0048 & 0.01547 & 0.00042 & 0.0512 & 0.0014 & 107.2 & 4.3 & 99 & 2.7 & 242 & 59 & 59.1 & 99.0 & 2.7 & 97.6 & 2 & 98.5 & 2.7 & 95.6 \\
\hline Z063 & 0.107 & 0.01 & 0.015 & 0.0003 & 0.0514 & 0.0048 & 102.3 & 9.5 & 95.9 & 1.9 & 220 & 180 & 56.4 & 95.9 & 1.9 & 95.5 & 2 & 95.5 & 2 & 95.9 \\
\hline Z064 & 0.096 & 0.0097 & 0.01521 & 0.00037 & 0.0469 & 0.0052 & 92.6 & 9 & 97.3 & 2.3 & 40 & 190 & -143.3 & 97.3 & 2.3 & 97.4 & 2.5 & 97.4 & 2.5 & 97.7 \\
\hline Z065 & 0.092 & 0.01 & 0.01524 & 0.00034 & 0.0439 & 0.0046 & 89.2 & 9.3 & 97.5 & 2.1 & -70 & 180 & 239.3 & 97.5 & 2.1 & 97.4 & 2 & 97.5 & 2 & 97.3 \\
\hline Z066 & 0.1002 & 0.0059 & 0.0148 & 0.00021 & 0.0492 & 0.003 & 96.8 & 5.5 & 94.7 & 1.4 & 150 & 120 & 36.9 & 94.7 & 1.4 & 94.4 & 1.5 & 94.5 & 1.5 & 92.2 \\
\hline Z067 & 0.119 & 0.013 & 0.01529 & 0.00035 & 0.0568 & 0.0063 & 114 & 12 & 97.8 & 2.2 & 380 & 220 & 74.3 & 97.8 & 2.2 & 96.6 & 2.4 & 96.7 & 2.4 & 97.6 \\
\hline
\end{tabular}




\begin{tabular}{|c|c|c|c|c|c|c|c|c|c|c|c|c|c|c|c|c|c|c|c|c|c|}
\hline Z068 & 0.099 & 0.0093 & 0.01514 & 0.00027 & 0.0478 & 0.0047 & 95.5 & 8.6 & 96.9 & 1.7 & 80 & 180 & -21.1 & 96.9 & 1.7 & 96.8 & 1.9 & 96.9 & 2 & 96.5 & 1.8 \\
\hline 2069 & 0.0959 & 0.0051 & 0.01509 & 0.00032 & 0.0464 & 0.0025 & 92.9 & 4.7 & 96.5 & 2 & 40 & 100 & -141.3 & 96.5 & 2.0 & 96.6 & 2.2 & 96.8 & 2.2 & 95.1 & 3 \\
\hline Z070 & 0.0971 & 0.0068 & 0.01358 & 0.0003 & 0.0518 & 0.0033 & 93.9 & 6.2 & 87 & 1.9 & 250 & 130 & 65.2 & 87.0 & 1.9 & 86.5 & 1.9 & 86.5 & 1.9 & 85.9 & 2.5 \\
\hline Z071 & 0.1027 & 0.0063 & 0.01548 & 0.00027 & 0.0481 & 0.0031 & 99 & 5.8 & 99 & 1.7 & 110 & 120 & 10.0 & 99.0 & 1.7 & 98.7 & 1.8 & 99 & 1.8 & 93.9 & 5.1 \\
\hline Z072 & 0.0954 & 0.007 & 0.01436 & 0.00032 & 0.0485 & 0.004 & 92.2 & 6.5 & 91.9 & 2.1 & 110 & 150 & 16.5 & 91.9 & 2.1 & 91.8 & 2.4 & 91.9 & 2.4 & 92 & 2.1 \\
\hline 2073 & 0.099 & 0.018 & 0.01443 & 0.00066 & 0.0494 & 0.0084 & 95 & 17 & 92.3 & 4.2 & 130 & 310 & 29.0 & 92.3 & 4.2 & 91.8 & 4 & 92.1 & 4 & 89.3 & 7.5 \\
\hline Z074 & 0.102 & 0.027 & 0.01018 & 0.00042 & 0.074 & 0.019 & 95 & 23 & 65.3 & 2.7 & 620 & 400 & 89.5 & 65.3 & 2.7 & 63.2 & 3.1 & 64.5 & 2.8 & 64.2 & 3.5 \\
\hline Z075 & 0.0967 & 0.0037 & 0.01438 & 0.00029 & 0.0487 & 0.0017 & 93.6 & 3.5 & 92.1 & 1.9 & 132 & 71 & 30.2 & 92.1 & 1.9 & 91.7 & 1.9 & 91.9 & 1.9 & 86.8 & 4.5 \\
\hline zo76 & 0.065 & 0.0046 & 0.01003 & 0.00027 & 0.0483 & 0.0039 & 64.9 & 4.7 & 64.3 & 1.7 & 100 & 150 & 35.7 & 64.3 & 1.7 & 64.2 & 1.9 & 64.3 & 1.9 & 64.3 & 1.7 \\
\hline Zo77 & 0.1019 & 0.005 & 0.01524 & 0.00032 & 0.0486 & 0.0023 & 98.4 & 4.6 & 97.5 & 2.1 & 129 & 96 & 24.4 & 97.5 & 2.1 & 97.1 & 2.1 & 97.4 & 2.1 & 95.2 & 3.6 \\
\hline Z078 & 0.086 & 0.012 & 0.01455 & 0.00036 & 0.0421 & 0.0062 & 83 & 11 & 93.1 & 2.3 & -120 & 240 & 177.6 & 93.1 & 2.3 & 94.2 & 2.4 & 94.3 & 2.4 & 92.9 & 2.3 \\
\hline 2079 & 0.168 & 0.038 & 0.01117 & 0.00037 & 0.109 & 0.022 & 159 & 34 & 71.6 & 2.3 & 1300 & 350 & 94.5 & 71.6 & 2.3 & 65.5 & 1.5 & 65.4 & 1.5 & 71.5 & 2.3 \\
\hline zo80 & 0.1011 & 0.0038 & 0.01345 & 0.00038 & 0.0549 & 0.0018 & 97.7 & 3.4 & 86.1 & 2.4 & 393 & 72 & 78.1 & 86.1 & 2.4 & 85.3 & 2.5 & 85.4 & 2.5 & 85.6 & 3.5 \\
\hline 2081 & 0.114 & 0.0069 & 0.01613 & 0.00034 & 0.0529 & 0.0039 & 109.5 & 6.3 & 103.2 & 2.2 & 300 & 150 & 65.6 & 103.2 & 2.2 & 102.5 & 2.3 & 102.6 & 2.3 & 103.1 & 2.2 \\
\hline zo82 & 0.0986 & 0.0093 & 0.01515 & 0.00041 & 0.0477 & 0.0046 & 95.2 & 8.5 & 96.9 & 2.6 & 90 & 180 & -7.7 & 96.9 & 2.6 & 96.9 & 2.9 & 97 & 2.9 & 97.2 & 2.7 \\
\hline Z083 & 0.1144 & 0.008 & 0.01559 & 0.00031 & 0.0535 & 0.0041 & 109.7 & 7.3 & 99.7 & 2 & 300 & 150 & 66.8 & 99.7 & 2.0 & 99 & 2.1 & 99 & 2.2 & 99.4 & 1.9 \\
\hline Zo84 & 5.366 & 0.072 & 0.3329 & 0.0032 & 0.1167 & 0.0013 & 1879 & 11 & 1852 & 16 & 1905 & 21 & 2.8 & 1905.0 & 21.0 & 1848 & 17 & 1846 & 18 & 1850 & 19 \\
\hline Z085 & 0.108 & 0.01 & 0.01535 & 0.00035 & 0.0498 & 0.0043 & 103.5 & 9.2 & 98.2 & 2.2 & 200 & 170 & 50.9 & 98.2 & 2.2 & 97.8 & 2.3 & 97.8 & 2.3 & 97.6 & 2.4 \\
\hline Z086 & 1.546 & 0.042 & 0.1469 & 0.0022 & 0.0758 & 0.0016 & 947 & 16 & 883 & 13 & 1084 & 43 & 18.5 & 883.0 & 13.0 & 878 & 13 & 875 & 13 & 881 & 14 \\
\hline 2087 & 0.0744 & 0.0093 & 0.01088 & 0.0004 & 0.0495 & 0.0057 & 72.4 & 8.6 & 69.8 & 2.5 & 120 & 200 & 41.8 & 69.8 & 2.5 & 69.3 & 2.6 & 69.3 & 2.6 & 68.2 & 3.3 \\
\hline Z088 & 0.097 & 0.012 & 0.01506 & 0.00029 & 0.0464 & 0.0054 & 93 & 11 & 96.4 & 1.9 & 20 & 200 & -382.0 & 96.4 & 1.9 & 96.3 & 1.9 & 96.5 & 2 & 93.2 & 3.2 \\
\hline$z 089$ & 0.247 & 0.011 & 0.03648 & 0.00059 & 0.0492 & 0.0021 & 223.9 & 9.2 & 231 & 3.6 & 155 & 89 & -49.0 & 231.0 & 3.6 & 228.7 & 4.2 & 231.3 & 3.7 & 207 & 17 \\
\hline$z 090$ & 0.103 & 0.011 & 0.01483 & 0.00047 & 0.051 & 0.0054 & 99 & 10 & 94.9 & 3 & 200 & 200 & 52.6 & 94.9 & 3.0 & 94.4 & 3.1 & 94.6 & 3.1 & 93.6 & 3.6 \\
\hline Z091 & 0.0947 & 0.007 & 0.01487 & 0.0005 & 0.047 & 0.0039 & 91.6 & 6.5 & 95.1 & 3.2 & 60 & 150 & -58.5 & 95.1 & 3.2 & 95.2 & 3.4 & 95.3 & 3.4 & 93.6 & 3.3 \\
\hline Z092 & 0.099 & 0.017 & 0.01403 & 0.00078 & 0.0511 & 0.008 & 94 & 16 & 89.8 & 5 & 150 & 280 & 40.1 & 89.8 & 5.0 & 91.9 & 7 & 91.9 & 7 & 89.9 & 5 \\
\hline 2093 & 0.1 & 0.01 & 0.01567 & 0.00032 & 0.0465 & 0.0048 & 96.3 & 9.5 & 100.2 & 2 & 30 & 180 & -234.0 & 100.2 & 2.0 & 100.2 & 2.2 & 100.4 & 2.2 & 99.6 & 2.4 \\
\hline Zo94 & 0.088 & 0.013 & 0.01421 & 0.00037 & 0.0454 & 0.0067 & 85 & 12 & 91 & 2.3 & -40 & 240 & 327.5 & 91.0 & 2.3 & 91.1 & 2.6 & 91.3 & 2.6 & 89.9 & 3 \\
\hline 2095 & 0.118 & 0.024 & 0.01417 & 0.00042 & 0.06 & 0.012 & 110 & 21 & 90.7 & 2.7 & 400 & 370 & 77.3 & 90.7 & 2.7 & 88.9 & 3.2 & 88.8 & 3.2 & 90.4 & 2.6 \\
\hline Z096 & 0.0988 & 0.0058 & 0.01506 & 0.00019 & 0.047 & 0.0026 & 95.5 & 5.4 & 96.4 & 1.2 & 80 & 110 & -20.5 & 96.4 & 1.2 & 96.3 & 1.3 & 96.4 & 1.3 & 95.5 & 2 \\
\hline Z097 & 0.1005 & 0.0052 & 0.01471 & 0.00056 & 0.0501 & 0.0026 & 97.1 & 4.7 & 94.1 & 3.5 & 190 & 110 & 50.5 & 94.1 & 3.5 & 93.8 & 3.7 & 93.9 & 3.7 & 92.9 & 3.9 \\
\hline 2098 & 0.113 & 0.013 & 0.01455 & 0.00032 & 0.0559 & 0.0063 & 107 & 12 & 93.1 & 2.1 & 350 & 220 & 73.4 & 93.1 & 2.1 & 92.1 & 2.1 & 92.1 & 2.1 & 92.5 & 2.4 \\
\hline Z099 & 0.0928 & 0.0082 & 0.01011 & 0.00027 & 0.0663 & 0.0052 & 89.8 & 7.5 & 64.8 & 1.7 & 730 & 170 & 91.1 & 64.8 & 1.7 & 63.3 & 1.7 & 63.2 & 1.7 & 64.7 & 1.8 \\
\hline Z100 & 0.0965 & 0.008 & 0.01426 & 0.00027 & 0.0495 & 0.0042 & 93.4 & 7.3 & 91.3 & 1.7 & 150 & 160 & 39.1 & 91.3 & 1.7 & 90.9 & 2 & 91.1 & 1.9 & 90.3 & 2.5 \\
\hline Z101 & 0.0958 & 0.0072 & 0.01485 & 0.0004 & 0.0467 & 0.0034 & 92.6 & 6.6 & 95 & 2.5 & 40 & 130 & -137.5 & 95.0 & 2.5 & 94.3 & 2.3 & 94.5 & 2.3 & 91.6 & 4.2 \\
\hline
\end{tabular}




\begin{tabular}{|c|c|c|c|c|c|c|c|c|c|c|c|c|c|c|c|c|c|c|c|c|}
\hline Z102 & 0.0942 & 0.0096 & 0.01378 & 0.00024 & 0.0498 & 0.0052 & 91 & 8.8 & 88.2 & 1.5 & 150 & 190 & 41.2 & 88.2 & 1.5 & 88 & 1.7 & 88 & 1.7 & 88.2 \\
\hline Z103 & 0.1111 & 0.0046 & 0.01636 & 0.00028 & 0.0494 & 0.0024 & 106.9 & 4.2 & 104.6 & 1.8 & 156 & 96 & 32.9 & 104.6 & 1.8 & 104.4 & 2.2 & 104.7 & 2.2 & 100.8 \\
\hline Z104 & 0.099 & 0.016 & 0.01438 & 0.00044 & 0.0493 & 0.0074 & 94 & 15 & 92 & 2.8 & 150 & 280 & 38.7 & 92.0 & 2.8 & 91.5 & 2.6 & 91.5 & 2.6 & 91.9 \\
\hline Z105 & 0.1018 & 0.0072 & 0.01484 & 0.00035 & 0.05 & 0.004 & 98.2 & 6.7 & 95 & 2.2 & 170 & 150 & 44.1 & 95.0 & 2.2 & 94.6 & 2.4 & 94.7 & 2.4 & 92.7 \\
\hline Z106 & 0.1037 & 0.0071 & 0.01559 & 0.0004 & 0.0503 & 0.0041 & 100 & 6.5 & 99.7 & 2.6 & 180 & 150 & 44.6 & 99.7 & 2.6 & 99.3 & 2.6 & 99.4 & 2.6 & 100.1 \\
\hline Z107 & 0.1003 & 0.0031 & 0.01496 & 0.00016 & 0.0489 & 0.0016 & 97 & 2.9 & 95.7 & 1 & 142 & 70 & 32.6 & 95.7 & 1.0 & 95.5 & 1.1 & 95.5 & 1 & 93.8 \\
\hline Z108 & 0.1174 & 0.0077 & 0.0158 & 0.00017 & 0.0538 & 0.0035 & 112.4 & 7 & 101.1 & 1.1 & 320 & 130 & 68.4 & 101.1 & 1.1 & 100.1 & 1.2 & 100.1 & 1.3 & 100.8 \\
\hline Z109 & 0.102 & 0.013 & 0.01503 & 0.00032 & 0.0481 & 0.0059 & 98 & 12 & 96.2 & 2 & 110 & 230 & 12.5 & 96.2 & 2.0 & 96.5 & 2 & 96.5 & 2 & 96 \\
\hline Z110 & 0.1007 & 0.0083 & 0.01509 & 0.00028 & 0.0484 & 0.004 & 97 & 7.6 & 96.6 & 1.8 & 110 & 160 & 12.2 & 96.6 & 1.8 & 96.5 & 1.9 & 96.5 & 2 & 96.3 \\
\hline Z111 & 0.1097 & 0.0055 & 0.0164 & 0.00031 & 0.0486 & 0.0026 & 105.6 & 5 & 104.9 & 1.9 & 130 & 110 & 19.3 & 104.9 & 1.9 & 104.4 & 2.1 & 104.8 & 2.1 & 102.9 \\
\hline Z112 & 0.105 & 0.014 & 0.01569 & 0.00041 & 0.0485 & 0.0064 & 101 & 13 & 100.4 & 2.6 & 90 & 230 & -11.6 & 100.4 & 2.6 & 100.1 & 2.7 & 100.3 & 2.7 & 100.2 \\
\hline Z113 & 0.1094 & 0.0072 & 0.01565 & 0.00032 & 0.0505 & 0.0031 & 105.2 & 6.5 & 100.1 & 2 & 230 & 130 & 56.5 & 100.1 & 2.0 & 98.9 & 1.8 & 99.1 & 1.8 & 98.6 \\
\hline Z114 & 0.1052 & 0.008 & 0.01577 & 0.00032 & 0.0485 & 0.0032 & 101.3 & 7.3 & 100.9 & 2 & 120 & 130 & 15.9 & 100.9 & 2.0 & 100.6 & 2 & 100.8 & 1.9 & 98.6 \\
\hline Z115 & 0.094 & 0.011 & 0.01499 & 0.00046 & 0.0457 & 0.0056 & 91 & 11 & 95.9 & 2.9 & -10 & 210 & 1059.0 & 95.9 & 2.9 & 97 & 3.4 & 97 & 3.4 & 95.9 \\
\hline Z116 & 0.123 & 0.013 & 0.01414 & 0.00045 & 0.0651 & 0.0073 & 117 & 12 & 90.5 & 2.8 & 660 & 210 & 86.3 & 90.5 & 2.8 & 88.4 & 3 & 88.5 & 3 & 88.3 \\
\hline Z117 & 0.119 & 0.01 & 0.01607 & 0.00027 & 0.0534 & 0.0045 & 113.6 & 9.3 & 102.8 & 1.7 & 300 & 170 & 65.7 & 102.8 & 1.7 & 101.8 & 1.8 & 102 & 1.8 & 101.6 \\
\hline Z118 & 0.0924 & 0.0049 & 0.01535 & 0.00027 & 0.0443 & 0.0025 & 89.6 & 4.5 & 98.2 & 1.7 & -50 & 100 & 296.4 & 98.2 & 1.7 & 98.5 & 1.9 & 98.7 & 1.8 & 95.7 \\
\hline Z119 & 0.099 & 0.011 & 0.01457 & 0.00028 & 0.0495 & 0.0052 & 95.3 & 9.7 & 93.2 & 1.8 & 130 & 190 & 28.3 & 93.2 & 1.8 & 92.5 & 2.1 & 92.5 & 2.1 & 93 \\
\hline Z120 & 0.0944 & 0.0093 & 0.0147 & 0.00034 & 0.048 & 0.0051 & 91.2 & 8.6 & 94.1 & 2.1 & 80 & 190 & -17.6 & 94.1 & 2.1 & 94 & 2.3 & 94.1 & 2.3 & 94.2 \\
\hline Z121 & 0.094 & 0.012 & 0.014 & 0.00034 & 0.049 & 0.0064 & 90 & 11 & 89.6 & 2.1 & 90 & 220 & 0.4 & 89.6 & 2.1 & 89.4 & 2.4 & 89.5 & 2.5 & 89.1 \\
\hline Z122 & 0.0989 & 0.0055 & 0.01473 & 0.00022 & 0.0489 & 0.0029 & 95.6 & 5.1 & 94.3 & 1.4 & 130 & 120 & 27.5 & 94.3 & 1.4 & 94.1 & 1.5 & 94.2 & 1.5 & 94.2 \\
\hline Z123 & 0.086 & 0.01 & 0.0124 & 0.00057 & 0.0514 & 0.0065 & 83.2 & 9.8 & 79.4 & 3.7 & 240 & 240 & 66.9 & 79.4 & 3.7 & 78.8 & 3.8 & 78.9 & 3.8 & 78.6 \\
\hline Z124 & 0.0861 & 0.0095 & 0.01479 & 0.00035 & 0.0424 & 0.0046 & 83.4 & 8.9 & 94.6 & 2.2 & -120 & 180 & 178.8 & 94.6 & 2.2 & 95.3 & 2.3 & 95.3 & 2.3 & 94.6 \\
\hline Z125 & 0.097 & 0.019 & 0.01435 & 0.00036 & 0.0502 & 0.0096 & 93 & 17 & 91.8 & 2.3 & 60 & 300 & -53.0 & 91.8 & 2.3 & 91 & 2.9 & 91.1 & 2.9 & 90.7 \\
\hline Z126 & 0.1033 & 0.0093 & 0.01529 & 0.00034 & 0.0492 & 0.0043 & 99.4 & 8.5 & 97.8 & 2.1 & 130 & 160 & 24.8 & 97.8 & 2.1 & 97.7 & 2.3 & 97.7 & 2.3 & 97.8 \\
\hline Z127 & 0.106 & 0.011 & 0.01469 & 0.00033 & 0.0524 & 0.0053 & 102 & 10 & 94 & 2.1 & 240 & 190 & 60.8 & 94.0 & 2.1 & 93.3 & 2.1 & 93.4 & 2.1 & 92.9 \\
\hline Z128 & 0.093 & 0.0075 & 0.01464 & 0.00028 & 0.0461 & 0.0039 & 90 & 7 & 93.7 & 1.8 & 20 & 150 & -368.5 & 93.7 & 1.8 & 93.8 & 2.1 & 93.9 & 2.1 & 93.3 \\
\hline Z129 & 0.104 & 0.009 & 0.01517 & 0.00029 & 0.0497 & 0.0044 & 100.1 & 8.2 & 97.1 & 1.8 & 150 & 160 & 35.3 & 97.1 & 1.8 & 97.2 & 2.1 & 96.9 & 2 & 95.9 \\
\hline Z130 & 0.095 & 0.017 & 0.01462 & 0.00052 & 0.0495 & 0.0094 & 91 & 16 & 93.5 & 3.3 & 50 & 320 & -87.0 & 93.5 & 3.3 & 93.3 & 3.4 & 93.3 & 3.4 & 93.5 \\
\hline Z131 & 0.084 & 0.012 & 0.01475 & 0.00037 & 0.0419 & 0.0061 & 85 & 13 & 94.4 & 2.3 & -130 & 230 & 172.6 & 94.4 & 2.3 & 94.9 & 2.6 & 95 & 2.6 & 92.8 \\
\hline Z132 & 0.1013 & 0.0093 & 0.01524 & 0.00042 & 0.0472 & 0.0037 & 97.6 & 8.5 & 97.5 & 2.6 & 90 & 150 & -8.3 & 97.5 & 2.6 & 97.3 & 2.7 & 97.5 & 2.7 & 96 \\
\hline Z133 & 0.0916 & 0.0068 & 0.01479 & 0.00032 & 0.0459 & 0.0036 & 88.7 & 6.3 & 94.7 & 2.1 & 10 & 140 & -847.0 & 94.7 & 2.1 & 94.3 & 2 & 94.4 & 2 & 94.6 \\
\hline Z134 & 0.085 & 0.012 & 0.01518 & 0.00037 & 0.0427 & 0.0064 & 82 & 11 & 97.1 & 2.3 & -140 & 230 & 169.4 & 97.1 & 2.3 & 97.8 & 2.7 & 97.8 & 2.7 & 97.4 \\
\hline Z135 & 0.092 & 0.012 & 0.01481 & 0.00036 & 0.0448 & 0.0057 & 88 & 11 & 94.7 & 2.3 & -10 & 220 & 1047.0 & 94.7 & 2.3 & 94.8 & 2.5 & 94.9 & 2.5 & 93.2 \\
\hline
\end{tabular}




\begin{tabular}{|c|c|c|c|c|c|c|c|c|c|c|c|c|c|c|c|c|c|c|c|}
\hline 0.0967 & 0.0038 & 0.01484 & 0.00017 & 0.0476 & 0.0018 & 93.7 & 3.5 & 95 & 1.1 & 84 & 76 & -13.1 & 95.0 & 1.1 & 94.8 & 1 & 95 & 1 & 93.2 \\
\hline 0.09 & 0.022 & 0.01417 & 0.00051 & 0.048 & 0.012 & 85 & 20 & 90.7 & 3.3 & 30 & 420 & -202.3 & 90.7 & 3.3 & 90.4 & 4.1 & 90.4 & 4.1 & 90.7 \\
\hline 0.111 & 0.013 & 0.01578 & 0.00031 & 0.0512 & 0.006 & 106 & 12 & 100.9 & 1.9 & 190 & 210 & 46.9 & 100.9 & 1.9 & 100.5 & 2.2 & 100.5 & 2.3 & 100.9 \\
\hline 0.098 & 0.017 & 0.01418 & 0.00048 & 0.0505 & 0.0091 & 94 & 16 & 90.8 & 3.1 & 90 & 310 & -0.9 & 90.8 & 3.1 & 90.5 & 3.3 & 90.5 & 3.4 & 90.8 \\
\hline 0.1136 & 0.0086 & 0.01567 & 0.00023 & 0.0524 & 0.0041 & 108.9 & 7.8 & 100.2 & 1.5 & 260 & 150 & 61.5 & 100.2 & 1.5 & 99.5 & 1.6 & 99.6 & 1.6 & 99.3 \\
\hline
\end{tabular}


Final207_ Final207_final206_Final206_Final207_Final207_finalAge FinalAge FinalAge FinalAge FinalAge FinalAge Concorda

$$
\text { (\%) }
$$

\begin{tabular}{|c|c|c|c|c|c|c|c|c|c|c|c|c|c|c|c|c|c|c|c|c|c|}
\hline Grains & $\begin{array}{l}\text { Finalzo'- } \\
235\end{array}$ & $235 \_2 s$ & $\begin{array}{c}\text { Final206_- } \\
238\end{array}$ & 238_2s & $\begin{array}{l}\text { Finalzor } \\
206\end{array}$ & $206 \_2 s$ & 207_235 & $\begin{array}{c}207 \_235 \\
\text { 2s }\end{array}$ & $\begin{array}{l}\text { FinalAge } \\
\text { 206_238 }\end{array}$ & $\begin{array}{c}206 \_238 \\
25\end{array}$ & $\begin{array}{l}\text { FinalAge } \\
\text { 207_206 }\end{array}$ & $\begin{array}{c}\text { 207_206 } \\
\text { _2s }\end{array}$ & $\begin{array}{l}\text { concorda } \\
\text { nce (\%) }\end{array}$ & Best age & $\begin{array}{c}\text { Best age } \\
2 \mathrm{~s}\end{array}$ & $\begin{array}{c}\text { nd207_23 } \\
5\end{array}$ & $\begin{array}{c}\text { nd207_23 } \\
5 \_2 s \\
\end{array}$ & $\begin{array}{c}3 \text { nd206_23 } \\
8\end{array}$ & $\begin{array}{c}\text { nd206_23 } \\
8 \_2 s \\
\end{array}$ & $\begin{array}{c}\text { nd207_20 } \\
6\end{array}$ & $\begin{array}{c}\text { nd207_20 } \\
6 \_2 s\end{array}$ \\
\hline ZB01 & 0.0387 & 0.0055 & 0.00549 & 0.00017 & 0.0506 & 0.0073 & 38.3 & 5.3 & 35.3 & 1.1 & 150 & 260 & 76.5 & 35.3 & 1.1 & 35.1 & 1.2 & 35.1 & 1.2 & 35.3 & 1.1 \\
\hline ZBO2 & 0.0432 & 0.0051 & 0.00585 & 0.00017 & 0.0555 & 0.0075 & 42.8 & 5 & 37.6 & 1.1 & 290 & 240 & 87.0 & 37.6 & 1.1 & 37.2 & 1.2 & 37.2 & 1.2 & 37.6 & 1.1 \\
\hline ZBO4 & 0.075 & 0.012 & 0.00611 & 0.00019 & 0.086 & 0.012 & 73 & 11 & 39.2 & 1.2 & 1050 & 300 & 96.3 & 39.2 & 1.2 & 37.1 & 1.2 & 37.1 & 1.2 & 39.2 & 1.2 \\
\hline ZB09 & 0.0477 & 0.006 & 0.00604 & 0.0002 & 0.0572 & 0.0065 & 47.2 & 5.8 & 38.8 & 1.3 & 440 & 240 & 91.2 & 38.8 & 1.3 & 38.3 & 1.3 & 38.3 & 1.3 & 38.8 & 1.3 \\
\hline ZB10 & 0.0395 & 0.0057 & 0.00584 & 0.00016 & 0.0489 & 0.0073 & 39.2 & 5.5 & 37.6 & 1 & 70 & 250 & 46.3 & 37.6 & 1.0 & 37.7 & 1.3 & 37.7 & 1.3 & 37.4 & 1.3 \\
\hline ZB11 & 0.0414 & 0.005 & 0.00566 & 0.00017 & 0.0533 & 0.0067 & 41.1 & 4.8 & 36.4 & 1.1 & 240 & 220 & 84.8 & 36.4 & 1.1 & 36.1 & 1.2 & 36.1 & 1.2 & 36.4 & 1.1 \\
\hline ZB12 & 0.0369 & 0.0074 & 0.00604 & 0.00022 & 0.0444 & 0.0091 & 36.4 & 7.2 & 38.8 & 1.4 & -110 & 330 & 135.3 & 38.8 & 1.4 & 39 & 1.6 & 39 & 1.6 & 38.8 & 1.4 \\
\hline ZB14 & 0.0372 & 0.0052 & 0.00596 & 0.00019 & 0.0457 & 0.0069 & 37 & 5.1 & 38.3 & 1.2 & -30 & 250 & 227.7 & 38.3 & 1.2 & 38.4 & 1.3 & 38.4 & 1.3 & 38.3 & 1.2 \\
\hline ZB15 & 0.0394 & 0.0027 & 0.005969 & 0.000092 & 0.0475 & 0.0035 & 39.2 & 2.6 & 38.37 & 0.59 & 100 & 140 & 61.6 & 38.4 & 0.6 & 38.3 & 0.62 & 38.27 & 0.63 & 38.45 & 0.58 \\
\hline ZB17 & 0.035 & 0.0022 & 0.005873 & 0.000079 & 0.0424 & 0.0025 & 34.9 & 2.1 & 37.75 & 0.5 & -120 & 100 & 131.5 & 37.8 & 0.5 & 37.87 & 0.53 & 37.93 & 0.53 & 37.99 & 0.68 \\
\hline ZB19 & 0.0411 & 0.0051 & 0.00573 & 0.00018 & 0.0521 & 0.0065 & 40.8 & 4.9 & 36.8 & 1.1 & 220 & 230 & 83.3 & 36.8 & 1.1 & 36.6 & 1.3 & 36.6 & 1.3 & 36.8 & 1.1 \\
\hline ZB22 & 0.0443 & 0.0099 & 0.00602 & 0.00021 & 0.054 & 0.012 & 43.7 & 9.6 & 38.7 & 1.4 & 220 & 390 & 82.4 & 38.7 & 1.4 & 38.4 & 1.5 & 38.4 & 1.5 & 38.7 & 1.4 \\
\hline ZB25 & 0.0429 & 0.004 & 0.00578 & 0.00014 & 0.0544 & 0.0051 & 42.6 & 3.9 & 37.14 & 0.89 & 320 & 180 & 88.4 & 37.1 & 0.9 & 36.73 & 0.9 & 36.73 & 0.9 & 37.14 & 0.89 \\
\hline ZB27 & 0.0376 & 0.005 & 0.00583 & 0.0002 & 0.0462 & 0.0062 & 37.3 & 4.9 & 37.5 & 1.3 & 0 & 230 & \#DIV/0! & 37.5 & 1.3 & 37.5 & 1.3 & 37.5 & 1.3 & 37.3 & 1.2 \\
\hline ZB28 & 0.055 & 0.01 & 0.0059 & 0.00019 & 0.067 & 0.011 & 53.8 & 9.5 & 37.9 & 1.2 & 700 & 280 & 94.6 & 37.9 & 1.2 & 36.7 & 1 & 36.7 & 1 & 37.9 & 1.2 \\
\hline ZB29 & 0.0409 & 0.0024 & 0.00624 & 0.00014 & 0.0467 & 0.0024 & 40.7 & 2.4 & 40.08 & 0.89 & 51 & 99 & 21.4 & 40.1 & 0.9 & 39.98 & 0.88 & 40 & 0.88 & 39.9 & 1 \\
\hline ZB30 & 0.0573 & 0.0084 & 0.00607 & 0.00012 & 0.0647 & 0.0082 & 56.2 & 7.9 & 39.01 & 0.74 & 690 & 260 & 94.3 & 39.0 & 0.7 & 38.05 & 0.82 & 38.03 & 0.82 & 39.27 & 0.99 \\
\hline ZB32 & 0.0405 & 0.0037 & 0.0063 & 0.00016 & 0.0474 & 0.0044 & 40.3 & 3.6 & 40.5 & 1 & 100 & 180 & 59.5 & 40.5 & 1.0 & 40.3 & 1 & 40.3 & 1 & 40.3 & 1.1 \\
\hline
\end{tabular}

